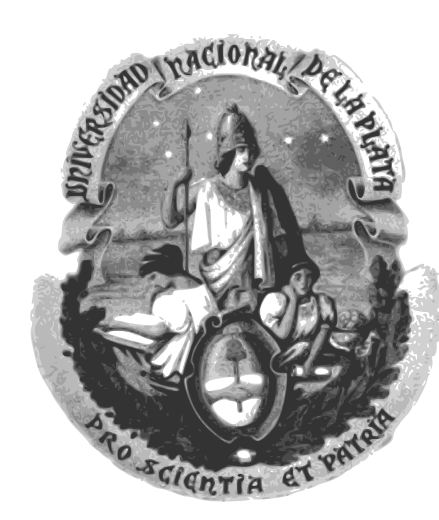

Universidad Nacional de la Plata

Facultad de Ciencias Exactas

Departamento de Ciencias Biológicas

Instituto de Biotecnología y Biología

Molecular

\title{
Desarrollo de herramientas moleculares para incrementar la aplicabilidad del baculovirus de Anticarsia gemmatalis en el control biológico de plagas
}

Santiago Haase

Tesis doctoral 

El presente trabajo de Tesis, para optar al grado de Doctor de la Facultad de Ciencias Exactas, área Ciencias Biológicas, ha sido realizado en el Instituto de Biotecnología y Biología Molecular (IBBM, UNLP-CONICET), Departamento de Ciencias Biológicas, Facultad de Ciencias Exactas, Universidad Nacional de La Plata bajo la dirección del Profesor Dr. Víctor Romanowski. 

MI RECONOCIMIENTO AL CONSEJO NACIONAL DE INVESTIGACIONES CIENTÍFICAS Y TÉCNICAS (CONICET), A LA AGENCIA NACIONAL DE PROMOCIÓN CIENTÍFICA Y TECNOLÓGICA (ANPCYT), Y A LA UNIVERSIDAD NACIONAL DE LA PLATA POR HABER HECHO POSIBLE LA REALIZACIÓN DEL PRESENTE TRABAJO.

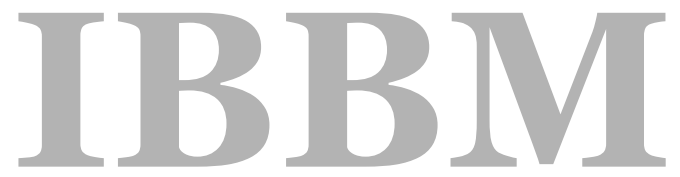

\section{CONICET A GENCIA}

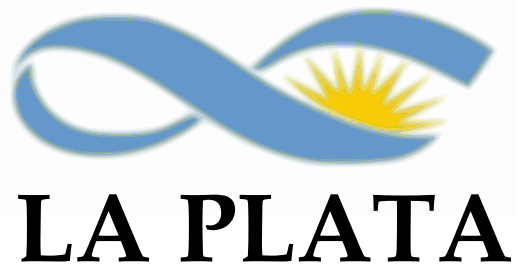

NACIONAL DE PRO MOCIÓ N

CIENTÍFICA Y TECNOLOGICA
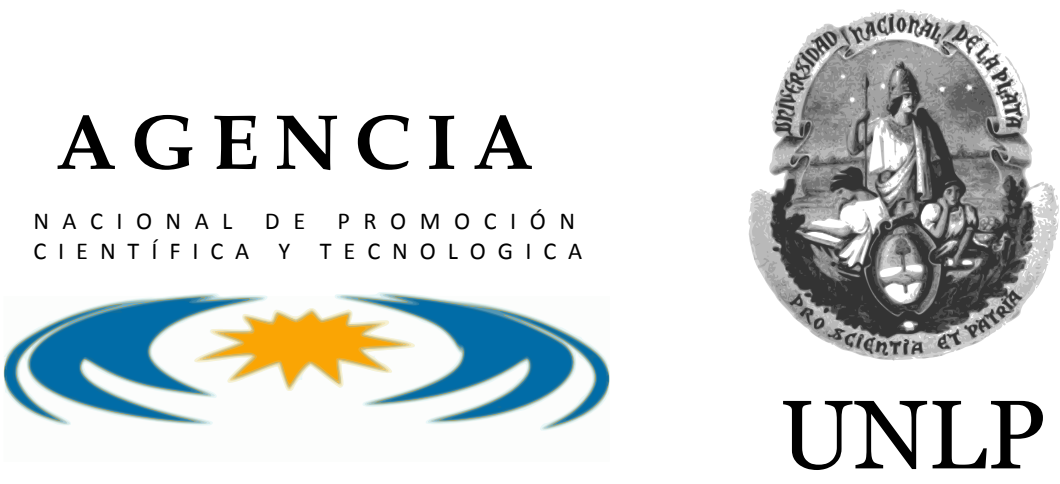



\section{Agradecimientos}

Al Dr. Víctor Romanowski. Por permitirme realizar el doctorado bajo su dirección. Por ayudarme a cumplir los objetivos, a través de la discusión y de la disposición de todos los recursos que se requirieran. Por guiarme en el desarrollo de mi investigación sin dejar nunca de lado el aprendizaje.

A la Ing. Alicia Sciocco de Cap, por aportar su experiencia en el tema y poner a mi disposición los recursos del INTA.

Al Dr. Ricardo Gómez. Por preocuparse, proponer ideas y facilitarme recursos de forma tan generosa.

A los Dres. Juan Claus y Oscar Taboga, por intercambiar discusiones y recursos que han sido de mucha utilidad en este trabajo.

Al Dr. Marcelo Berreta, por compartir generosamente su experiencia en el tema.

A mis compañeros de laboratorio. Por formar un grupo excelente con el cual da placer compartir el trabajo.

A Mati, por ser un excelente compañero, siempre dispuesto a ayudarte en cualquier situación. Por compartir su trabajo conmigo y ayudarme a encontrar soluciones para el mío.

A Leti, por ayudarme en mi etapa de formación y siempre encontrarse dispuesta a dar una mano. Por su gran ayuda en la revisión de esta tesis.

A Ricardo Salvador. Por darme una mano siempre que le fue posible.

A Maia, por preocuparse siempre. Por su asombrosa claridad para plantear soluciones y mejorar las cosas.

A la Gran Prêtre, porque su inusitada visión del mundo siempre nos deja pensando.

A Caro, por su compromiso con el laboratorio y su vocación de ayuda.

A Emy, por su gran calidad de persona y su gran empatía.

A Flor (otra flamante investigadora), por su aporte de valiosa ayuda en muchos aspectos de este trabajo.

A los recién llegados Agustín y Laura V. Porque en poco tiempo han demostrado una predisposición y un entusiasmo muy destacable hacia el grupo.

A Lucre y a Jesi, dos grandes personas que se fueron a probar suerte. Mis mejores deseos.

A Mandy, por su sentido del humor y compañerismo.

A Laura y a Carlos, por confiar en mí. Porque aprendí mucho del proceso fue un placer poder compartir lo que pude brindar.

A Mauro, por confiar en mis consejos. Por sus charlas de River (hacían falta).

A Karina, por su alegría y buena predisposición. 
A los otros miembros que pasaron por el laboratorio, siempre dejando algo. Fernanda, Javier, Ale, Leo, Romina.

A María y Débora, del IMyZA, por haber mantenido la cría de los insectos con los cuales se realizaron los experimentos en esta tesis.

A los investigadores del IBBM, que han colaborado a través de los intercambios en reuniones y permitiendo generosamente el uso de los equipamientos necesarios: Antonio Lagares, Mariano Pistorio, Anibal Lodeiro, Laura García, Daniela Hozbor, Mario Aguilar, Flavio Blanco, Eugenia Zanetti, Silvina López-García, Florencia Del Papa, Federico Sisti y Julieta Fernández. A los investigadores que no aparecen aquí pero han contribuido igualmente al desarrollo de este trabajo.

A los profesionales y técnicos de apoyo del instituto, sin cuya colaboración el desarrollo de este trabajo sería inimaginable. A Caty, Bernabé, Abel, Silvana, Paula, Larissa, Ulises, Juan, Luciana y Claudio. A Rubencito, por colaborar en lo que estuviera a su alcance.

A Silvia Moya, Gisela Verdecanna y Sebastián Moldes, por su contribución en las tareas administrativas.

Al resto de los integrantes del IBBM, por conformar un grupo de trabajo excelente.

A los investigadores y colegas que han acompañado mi tarea en el ámbito docente: en particular a Flavio Blanco y Celina Castuma.

Al Dr. José María García Bourg, por haber sido un modelo que inspiró la vocación científica en mí. A su esposa, Verónica San Román, por su enorme empatía.

A mis padres, Carlos y Silvia por haber confiado en mí apoyando mi carrera y haber estado siempre en los momentos en que fue necesario. Por haberme enseñado los valores del esfuerzo y la vocación por el trabajo.

A mis hermanos, por haberme acompañado todos estos años desde la distancia.

A mis sobrinos, por traer tanta alegría a la familia.

Al resto de mi familia.

A mi novia, Estefy, a quien dedico este trabajo. Por soportar este proceso y por su enorme compromiso y compañía para construir conmigo todo esto. 
Lista de las principales abreviaturas utilizadas en este trabajo

Gen 1629. Homólogo del gen 1629 de AcMNPV

1629 1629 o PP78/83 (proteína). Homóloga de la proteína 1629 de AcMNPV

AcMNPV Virus de la poliedrosis nuclear múltiple de Autographa californica

AgMNPV Virus de la poliedrosis nuclear múltiple de Anticarsia gemmatalis

BV Virus brotado/s o virión/es brotantes

CATH Catepsina viral (proteína)

CHI-A

Quitinasa A (proteína)

ChiA

Quitinasa A (gen)

$\mathrm{cm}$

Centímetros

DNA

Ácido desoxirribonucleico

dpi días post infección

dsRed gen de la proteína fluorescente roja

DsRed Proteína fluorescente roja

dw Downstream (posterior, río abajo)

E. coli

Escherichia coli

EEUU

Estados Unidos de América

EFP

Proteína de fusión

egt

gen de la ecdisteroide UDP-glucosiltransferasa.

enh o vef

enhancins (enhancinas) o factores virales aumentadores (genes)

EpapGV

Virus de la granulosis de Epinotia Aporema

$\mathrm{F}$

Proteína de fusión

$g f p$

Proteína verde fluorescente (gen)

GFP

Proteína verde fluorescente (proteína)

gp37

gp37 (gen)

GP37

GP37 (proteína)

GP64 o GP67

Proteína de fusión GP64

gra

Granulina (gen)

GV

Virus de la granulosis

$\mathrm{Ha}$.

High Five $^{T M}$

Hectáreas

hpi

Línea celular derivada de Trichoplusia ni, (BTI-TN-5B1-4)

horas post infección

ie-1

ie-1 (gen inmediato temprano 1)

IE-1

IE-1 (proteína)

$\mathrm{LD}_{50}$

Dosis letal media

$\mathrm{LT}_{50}$

Tiempo letal medio

MIP

Manejo integrado de plagas

MLK

Proteínas tipo mucina

MNPV

Virus de la poliedrosis nuclear múltiple

NC

Nucleocápsides

NPV

Virus de la poliedrosis nuclear

OB

Cuerpo/s de oclusión

ODV

Virus derivado/s del cuerpo de oclusión 
Lista de las principales abreviaturas utilizadas en este trabajo (continuación)

\begin{tabular}{|c|c|}
\hline ori & Origen de replicación \\
\hline p10 & p10 (gen) \\
\hline P10 & P10 (proteína) \\
\hline PBS & Buffer fosfato salino \\
\hline PE & Envoltura poliédrica \\
\hline PCR & Reacción en cadena de la polimerasa \\
\hline PP78/83 & PP78/83 o 1629 (proteína) \\
\hline PM & Membrana peritrófica \\
\hline polh & Poliedrina (gen) \\
\hline polh+ & Poliedrina positivo (genotipo) \\
\hline polh- & Poliedrina negativo (genotipo) \\
\hline qPCR & PCR cuantitativa en tiempo real \\
\hline RNA & Ácido ribonucleico \\
\hline SDS & Dodecil sulfato de sodio \\
\hline SDS-PAGE & Electroforesis en gel de poliacrilamida en presencia de SDS \\
\hline Sf9 & Línea celular derivada de Spodoptera frigiperda \\
\hline SOE-PCR & PCR de empalme por superposición de extremos \\
\hline SNPV & Virus de la poliedrosis nuclear simple \\
\hline Tn. & Toneladas \\
\hline tox34 & Gen tox34 de Pyemotes tritici \\
\hline TxP-I & TxP-I (toxina producto proteico del gen tox34) \\
\hline up & Upstream (anterior, río arriba) \\
\hline UV & Luz ultravioleta \\
\hline$v$-cath & Catepsina viral (gen) \\
\hline VDCC & Transportadores de calcio dependientes de voltaje (neuronales) \\
\hline vp39 & vp39 (gen) \\
\hline VP39 & VP39 (proteína) \\
\hline X-gal & 5-bromo-4-cloro-3-indolil- $\beta$-D-galactopiranósido \\
\hline
\end{tabular}




\section{Resumen}

El virus de Anticarsia gemmatalis, AgMNPV, es el bioinsecticida viral que ha sido más utilizado en el mundo. Este virus, perteneciente a la familia de los baculovirus, actúa específicamente sobre larvas de la oruga de las leguminosas, Anticarsia gemmatalis, un lepidóptero que causa severos daños en los cultivos de soja y otras leguminosas. A pesar del amplio uso de AgMNPV en países con climas cálidos, como Brasil y Paraguay, la aplicación de este baculovirus en Argentina se ha visto limitada por su tiempo de acción lento en comparación con los insecticidas químicos de amplio espectro.

El objetivo del trabajo desarrollado en esta tesis consiste en la generación de herramientas que permitan mejorar las posibilidades de aplicación de AgMNPV como bioinsectida mediante el uso de estrategias de biología molecular.

En el segundo capítulo se describe el desarrollo de un sistema de recombinación que establece la base para la modificación genética de AgMNPV.

En el tercer capítulo se describe el desarrollo de líneas celulares derivadas de lepidópteros que expresan la proteína mayoritaria del cuerpo de oclusión de los baculovirus, poliedrina. Este desarrollo permitió la generación de cuerpos de oclusión de AgMNPV de genotipo poliedrina negativo ( $\left.p o / h^{-}\right)$, lo cual representa un avance importante en la generación de bioinsecticidas con una barrera de contención ecológica.

En el cuarto capítulo se detalla el desarrollo de una línea celular que expresa un gen indicador (GFP) inducible por la infección con baculovirus. Este tipo de líneas celulares representa un recurso importante para la manipulación cotidiana de baculovirus en cultivo celular y para estudios básicos.

En el quinto capítulo se describe la transactivación de promotores del alfabaculovirus AgMNPV y del betabaculovirus EpapGV por parte de factores de transcripción provistos por la infección con AgMNPV en un entorno celular en el que no se replica EpapGV. Este tipo de estudio permite avizorar la perspectiva de expandir el rango de hospedador de AgMNPV a través del desarrollo de baculovirus recombinantes quiméricos entre dos especies de la familia.

En el sexto capítulo se describen los avances en el desarrollo de sistemas de recombinación más eficientes para AgMNPV y se discuten algunos resultados novedosos acerca de la función del gen 1629 en la replicación y la infectividad de los baculovirus en cultivo celular. 


\section{Abstract}

Anticarsia gemmatalis Multiple Nucleopolyhedrovirus is the most extensively used virus pesticide in the world. This member of the Baculoviridae acts specifically on velvetbean caterpillar, a lepidopteran insect that causes massive damage to soybean and other legumes crops. Despite the successful use of AgMNPV in warm climate conditions (Brazil and Paraguay), its application to protect crops in temperate climate (Argentina) has been limited due to its slow speed of action when compared with broad-spectrum chemical pesticides.

The aim of the present work is the development of tools and strategies to improve the feasibility of use of AgMNPV as biopesticide employing molecular biology approaches.

In the second chapter, the development of a recombination system that allows the genetic engineering of AgMNPV is described.

The third chapter is a report on the development of lepidopteran transgenic cell lines expressing the major occlusion body protein, polyhedrin. This development allowed the generation of occlusion bodies containing only AgMNPV virions with a polyhedrin negative (polh) genotype. This represents a considerable step forward for the generation of environmentally contained biopesticides.

The fourth chapter is a description of the generation of a transgenic cell line expressing a reporter gene (GFP) inducible by virus infection. This type of cell lines facilitates the handing of baculoviruses in the lab and represents a valuable tool for fundamental biological studies.

The fifth chapter details the results of a study on transactivation of alphabaculovirus AgMNPV and betabaculovirus EpapGV promoters by transcription factors supplied by AgMNPV infection in a cellular environment not permissive for EpapGV. This study aims at evaluating the possibilities of expanding the host range of a baculovirus by the generating chimeric recombinant baculovirus containing genomic fragments of two different species.

In the sixth chapter, the advances in the development of a highly efficient AgMNPV recombination and selection system are described. Novel results found about the functions of 1629 gene in the infectivity of baculovirus in cell culture are discussed as well. 


\section{Índice}

\section{Capítulo 1. Introducción General}

1.1 El cultivo de soja $\quad 2$

1.2 Biología de los Baculovirus

1.3 Control biológico de A. gemmatalis con el baculovirus AgMNPV 23

1.4 Granulovirus de Epinotia aporema 25

1.5 Mejoramiento genético de baculovirus para el control biológico de plagas $\quad 26$

\begin{tabular}{ll} 
Objetivos & 27 \\
\hline
\end{tabular}

Referencias $\quad 28$

Capítulo 2. Desarrollo de un sistema de recombinación para la obtención de AgMNPV modificados.

$\begin{array}{ll}2.1 \text { Introducción } & 36 \\ 2.2 \text { Materiales y métodos } & 37 \\ \text { 2.3 Resultados } & 43 \\ \text { 2.4 Discusión } & 49 \\ \text { Referencias } & 51\end{array}$

Capítulo 3. Estudio de la complementación funcional del gen de poliedrina entre dos alfabaculovirus.

$\begin{array}{ll}\text { 3.1 Introducción } & 54 \\ \text { 3.2 Materiales y métodos } & 58 \\ \text { 3.3 Resultados } & 64 \\ \text { 3.4 Discusión } & 69 \\ \text { Referencias } & 71\end{array}$

Capítulo 4. Desarrollo de una línea celular para la titulación y el monitoreo de infecciones de baculovirus

$\begin{array}{ll}4.1 \text { Introducción } & 73 \\ 4.2 \text { Materiales y métodos } & 74 \\ \text { 4.3 Resultados } & 75 \\ \text { 4.4 Discusión } & 78 \\ \text { Referencias } & 81\end{array}$

Capítulo 5. Análisis de la transactivación transcripcional de elementos promotores entre alfa y betabaculovirus.

$\begin{array}{ll}5.1 \text { Introducción } & 83 \\ 5.2 \text { Materiales y métodos } & 84 \\ 5.3 \text { Resultados } & 85 \\ 5.5 \text { Discusión } & 89 \\ \text { Referencias } & 91\end{array}$

Capítulo 6. Desarrollo de un sistema de recombinación de alta eficiencia para AgMNPV

$\begin{array}{lr}5.1 \text { Introducción } & 93 \\ 5.2 \text { Materiales y métodos } & 96 \\ 5.3 \text { Resultados } & 104 \\ 5.5 \text { Discusión } & 107 \\ \text { Referencias } & 109\end{array}$

\section{Conclusiones y perspectivas}

Anexo: Materiales y métodos

$\begin{array}{ll}\text { A.1 Materiales } & 117\end{array}$

$\begin{array}{ll}\text { A.2 Métodos } & 119\end{array}$

A.3 Lista de primers utilizados y reacciones de PCR 122

$\begin{array}{lr}\text { Referencias } & 129\end{array}$ 



\section{Capítulo 1}

\section{Introducción}





\subsection{El cultivo de soja}

La soja (Glycine max) es una especie de la familia de las leguminosas (Fabaceae o Leguminosae) cultivada por sus semillas. Debido a su alto contenido proteico y de aceites, el grano de soja y sus subproductos (aceite y harina de soja, principalmente) se utilizan para la alimentación humana y la formulación de alimentos balanceados para el ganado.

La soja varía en crecimiento, hábito y altura. Puede crecer desde $20 \mathrm{~cm}$ hasta 2 metros de altura. Las vainas, tallos, y hojas están cubiertas por finos pelos marrones o grises. Las hojas son trifoliadas, con 3 a 4 prospectos por hoja. Los prospectos son de $6-15 \mathrm{~cm}$ de longitud y de $2-7 \mathrm{~cm}$ de ancho. Las hojas caen antes de que las semillas estén maduras. Las flores grandes, inconspícuas y autofértiles, nacen en la nervadura de la hoja y son blancas, rosas o púrpuras.

El fruto es una vaina pilosa que contiene entre dos y cuatro semillas (Figura 1.1). Las semillas poseen una cubierta resistente que protege el tejido germinal de cualquier daño. Juntos, el aceite y el contenido de proteínas suman el aproximadamente el $60 \%$ del peso seco de la soja; proteína $40 \%$ y aceite $20 \%$. El remanente consiste en $35 \%$ de carbohidratos y alrededor del 5\% de ceniza.

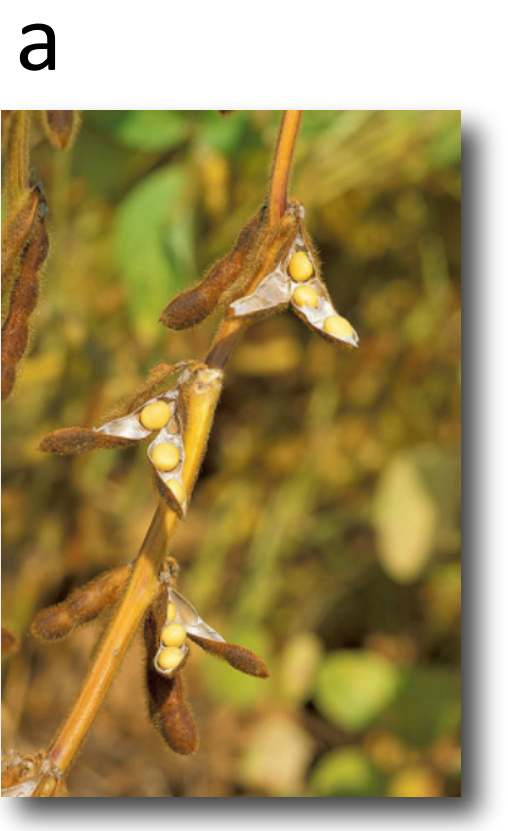

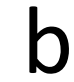

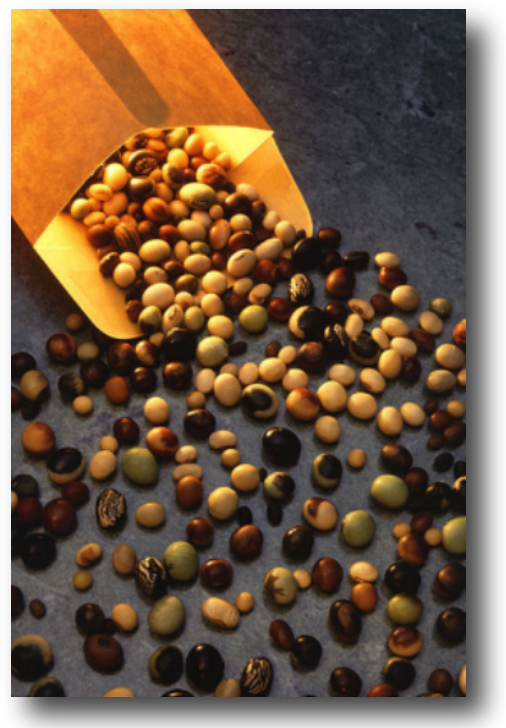

Figura 1.1. a) Vainas de una planta de soja, con semillas en su interior. Imagen del Departamento de Agricultura de EEUU. b) Semillas de soja, National Soybean Germplasm Collection en Illinois. Foto de Scott Bacuer, Nro de imagen K5267-7. 
La soja es un alimento muy rico en proteínas. Algunos derivados de ésta se consumen en sustitución de los productos cárnicos debido a que su proteína es de una calidad comparable a la de la carne. La soja aporta los 8 aminoácidos esenciales en la edad adulta (Renkema, 2001). El aceite de soja crudo es rico en ácidos grasos poliinsaturados y posee los ácidos grasos esenciales omega 3 y omega 6 , por lo cual resulta un buen complemento para dietas en las que abundan carnes rojas y carbohidratos (Fukushima, 1991).

Hace más de un siglo que en Argentina se desarrolla el cultivo de soja para la producción de granos como materia prima de uso directo o indirecto a través de sus derivados industriales. Argentina es el tercer productor mundial de poroto de soja luego de Estados Unidos y Brasil. Medida en volumen, su participación en el mercado supera el 20\%. La combinación entre alta producción y bajo consumo doméstico hacen de Argentina el mayor exportador mundial de aceite de soja.

En las últimas décadas, la evolución tecnológica relacionada con semillas, maquinarias y manejo del cultivo, sumada a la calidad de los suelos y al clima favorable ha promovido la intensificación y expansión de esta actividad.

El incremento en la producción de soja en el país en los últimos años fue ocasionado principalmente por un aumento en el área cultivada, a través de la incorporación de tierras marginales para el cultivo, en especial con el desplazamiento de zonas ganaderas. A pesar de esto, los continuos desarrollos tecnológicos han permitido que esta expansión tuviera lugar con un crecimiento continuo del rendimiento productivo (Figura 1.2).

\subsubsection{Plagas comunes de la soja}

La soja es atacada por una gran variedad de especies de plagas entre las que se encuentran orugas defoliadoras durante el período vegetativo y chinches durante la etapa de fructificación.

Las modificaciones en la práctica del cultivo de la soja que han tenido lugar en los últimos años referentes al desplazamiento del período de sembrado a épocas más tempranas y al cambio del sistema de cultivo tradicional con laboreo del suelo por la siembra directa (Panigatti et al., 1998) han contribuido a la proliferación de especies dañinas como 
moluscos (babosas y caracoles), crustáceos (bicho bolita) y otras plagas como las orugas cortadoras debido a que estos organismos son comunes en primavera y el sistema de siembra directa, en función de la cobertura de rastrojo y alto nivel de humedad, favorece su proliferación (Aragón et al., 1998).

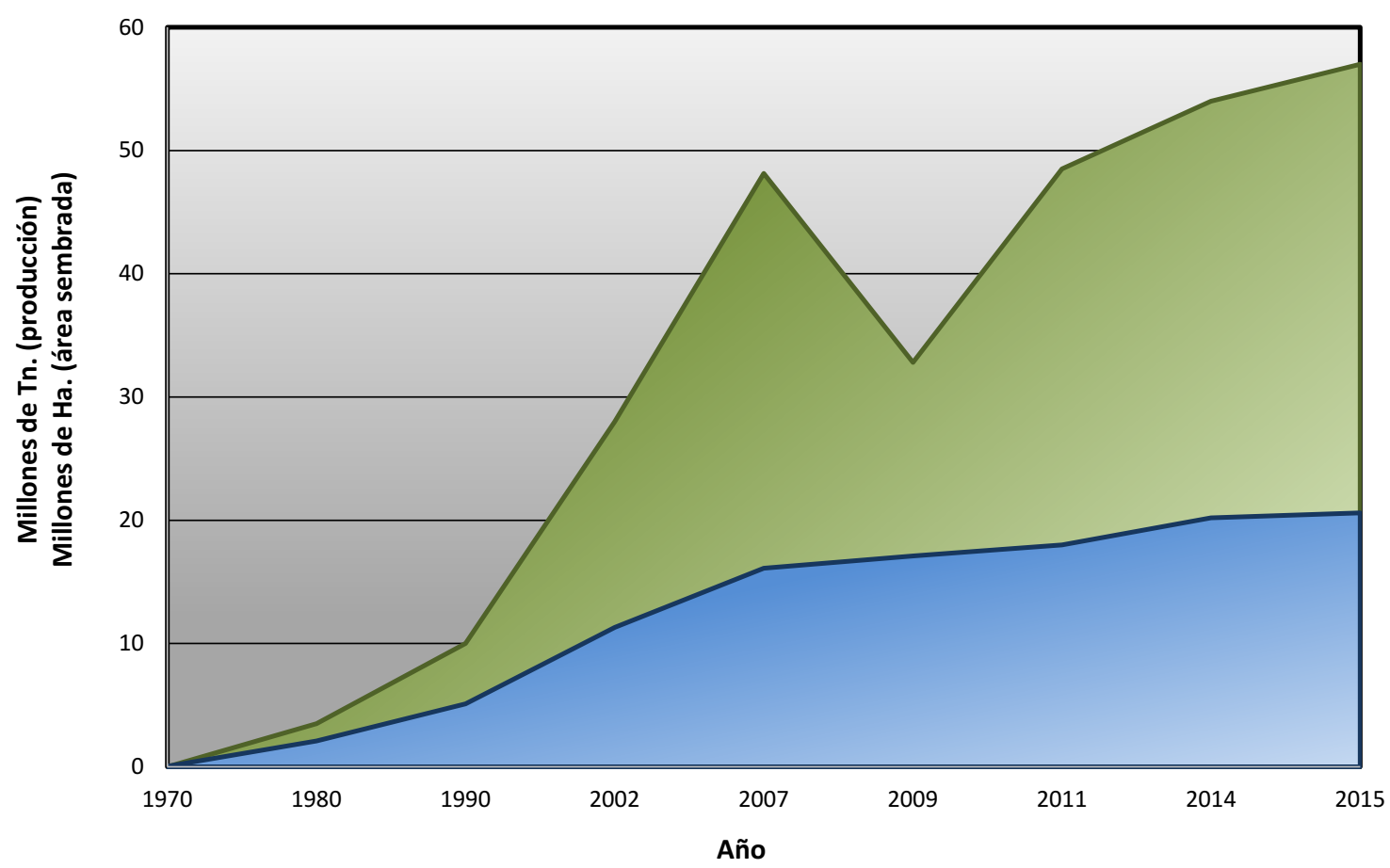

Figura 1.1. Evolución de la producción (área en verde) y del área cultivada de soja en Argentina (área celeste). Los resultados de la producción de la temporada 2014/2014 pertenecen a estimaciones del departamento de Agricultura de EEUU. Fuentes: Bolsa de Comercio de Rosario http://www.bcr.com.ar. Departamento de Agricultura de EEUU http://www.usda.gov.

Ante esta situación, las medidas para combatir el ataque de plagas se han visto intensificadas y las estrategias más difundidas consisten en la aplicación de insecticidas de origen químico y monitoreo exhaustivo de las poblaciones de organismos plagas.

\subsubsection{La oruga de las leguminosas, Anticarsia gemmatalis}

Anticarsia gemmatalis (Lepidoptera: Noctuidae) es nativa de regiones tropicales y subtropicales del hemisferio oeste, fue descripta por primera vez en 1903 en Florida (Hinds y Osterberger, 1931). En nuestro país, se encuentra en la región Pampeana, Mesopotamia y Norte, con desarrollo de poblaciones masivas en Córdoba y Santa Fe (lannone, 2007), donde el área de cultivo de soja es extensa (Figura 1.3). Además, puede 
atacar cultivos de maní, alfalfa, poroto, algodón, trigo, lino y algunas hortalizas. Los huevos son depositados en forma aislada, principalmente en el envés de las hojas. Durante el primer estadio se alimentan del parénquima, dejando la epidermis superior de las hojas casi intacta; en el segundo, se alimentan de la porción intervenal del tejido y de las nervaduras más pequeñas. A medida que aumenta su desarrollo su voracidad también se incrementa (Gutiérrez y Pulido, 1978). Las larvas son esencialmente filófagas, pero en ocasiones atacan también las vainas que aún no formaron granos, siendo este comportamiento la principal causa del daño económico producido por el insecto. Una larva llega a consumir entre 100 y $110 \mathrm{~cm}^{2}$ de hojas de soja.

Anticarsia gemmatalis es uno de las insectos plagas más perjudiciales para el cultivo de soja en Argentina y ha alcanzado altos niveles poblacionales debido a la expansión del área sembrada y las prácticas de cultivo establecidas. Para el control de la especie suelen utilizarse insecticidas químicos de amplio espectro a base de piretroides y organofosforados (Aragón, 2007).

\subsubsection{Manejo integrado de plagas}

El manejo integrado de plagas (MIP) tuvo nacimiento en la década de 1950 en respuesta a dos grandes problemáticas ocasionadas por la aplicación de insecticidas químicos como único método de control de plagas: la aparición de plagas resistentes a los productos y el desarrollo de nuevas plagas, que en un inicio eran minoritarias, a causa de la aniquilación de insectos competidores naturales. El entonces llamado "control integrado" combinaba el uso de control biológico sumado al químico y definía sus

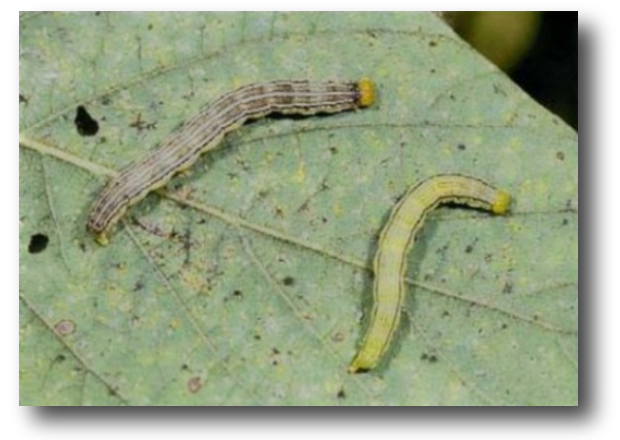

Figura 1.3. Dos fenotipos observados en poblaciones de larvas de Anticarsia gemmatalis alimentándose sobre el follaje de una planta de soja. Se advierten daños incipientes en la hoja. acciones en base al concepto clave de "umbral de daño económico".

Posteriormente, el control integrado fue incluyendo otras tácticas supresivas como resistencia de la planta hospedadora y manejo de cultivos. Actualmente, el Manejo Integrado de Plagas (MIP) comprende el conjunto de acciones tendientes a evitar, atenuar o reducir el impacto de las plagas sobre los cultivos, en tanto los objetivos y 
procedimientos de tales acciones se comprendan claramente (Kogan, 1998). Además, los intereses del MIP no están concentrados solamente en el daño económico ocasionado a los cultivos sino en el desarrollo de alternativas de control que afecten al medioambiente en la menor medida posible.

\subsubsection{Control biológico de plagas}

El control biológico de plagas puede definirse como la eliminación o atenuación de una especie que ha adquirido la categoría de plaga por otro organismo vivo que es introducido al ambiente (Saxena, 2008). Por lo tanto, se trata de un manejo de la peste mediante enemigos, ya sean naturales o modificados genéticamente. Los insectos, además de sus predadores naturales, tienen como enemigos a muchos patógenos naturales que incluyen bacterias, hongos, nemátodos y virus. Estos microorganismos, cuando son administrados artificialmente, pueden controlar de manera efectiva la población plaga, incluso de manera permanente, si es que la especie patógena logra establecerse en la población hospedadora.

El control biológico, además de resultar ventajoso desde el punto de vista económico, reduce la exposición de los trabajadores del campo a agroquímicos potencialmente peligrosos y disminuye la contaminación ambiental y de los alimentos con estos productos.

La utilización de pesticidas microbianos es probablemente el método de control biológico más difundido y económico. Entre los pesticidas de origen bacteriano, Bacillus thuringiensis ha sido el más exitoso, acaparando cerca del $2 \%$ del mercado global de insecticidas y aproximadamente el $75 \%$ del mercado de bioinsecticidas, sin tener en cuenta el empleo de plantas transgénicas que expresan proteínas de esta bacteria (Shelton et al., 2002).

Se conocen unas 15 familias diferentes de virus capaces de infectar insectos (Entwistle y Evans, 1985; Moore et al., 1987). Los virus pertenecientes la familia de los baculovirus han sido los más utilizados para el desarrollo de bioinsecticidas comerciales. Estos virus son altamente específicos, con frecuencia limitados a una única especie hospedadora, lo que supone ventajas en relación al nivel de bioseguridad y alteración mínima del nicho ecológico. En un comienzo, los tiempos de acción relativamente lentos, que condujeron 
a los usuarios (acostumbrados a los insecticidas químicos de rápida acción) a catalogarlos de inefectivos y las dificultades técnicas limitaron la expansión comercial y la aplicación a gran escala de los baculovirus. Sin embargo, la actitud de desconfianza fue revirtiéndose y la aplicación de baculovirus se fue convirtiendo en una alternativa atractiva para la protección de cultivos a largo plazo.

Hasta la fecha, el proyecto más exitoso ha sido el implementado en Brasil, con la administración del baculovirus de Anticarsia gemmatalis (AgMNPV) en más de dos millones de hectáreas de cultivos de soja por año (Moscardi, 1999; Moscardi y Santos, 2005). Este proyecto ha revitalizado el interés en los baculovirus como bioinsecticidas y gradualmente muchos países han incrementado sus líneas de investigación en el tema. En la tabla 1.1 se puede observar una lista de los baculovirus comerciales de aplicación más relevante en Latinoamérica.

\subsection{Biología de los baculovirus}

\subsubsection{Introducción}

Los baculovirus comprenden una familia de virus específicos de artrópodos. Han sido aislados a partir de unas 600 especies diferentes de insectos, pertenecientes a los órdenes Lepidoptera, Hymenoptera, Diptera, Orthoptera, Coleoptera, Neuroptera, Thysaneura and Trichoptera (Adams y McClintock, 1991; Herniou et al., 2003; Larsson, 1984; Martignoni e Iwai, 1986; Murphy et al., 1995; Tinsley y Kelly, 1985). A pesar de eso, hasta el momento sólo se encuentran aceptadas oficialmente especies de baculovirus que infectan artrópodos de los órdenes Lepidoptera, Diptera e Hymenoptera y de éstas, la gran mayoría de ellas han sido aisladas de lepidópteros. Hasta el momento, no se ha observado la infección de baculovirus en ningún vertebrado, por lo cual su aplicación y manipulación se considera segura para el hombre.

El genoma de estos virus, que varía entre los 80 y $180 \mathrm{kpb}$, se encuentra en forma de DNA circular de doble cadena y empaquetado en una nucleocápside con forma de bastón. Las nucleocápsides se encuentran envueltas en una membrana lipoproteica. 


\begin{tabular}{|c|c|c|c|c|c|}
\hline Virus & Hospedador & Cultivo & Producto & País & Compañía \\
\hline $\begin{array}{l}\text { Anticarsia } \\
\text { gemmatalis } \\
\text { MNPV }\end{array}$ & Anticarsia gemmatalis & Soja & $\begin{array}{l}\text { Baculo-soja }{ }^{1}, \\
\text { Baculovirus Nitral }^{2} \text {, } \\
\text { Coopervirus } \mathrm{SC}^{3}, \\
\text { Protege } \\
\text { Multigen }^{5}\end{array}$ & Brasil & $\begin{array}{l}\text { Nova Era Biotecnología } \\
\text { Agrícola }^{1}, \text { Nitral Urbana }^{2}, \\
\text { COODETEC }^{3} \text {, } \\
\text { Milenia }^{4} \\
\text { EMBRAPA }^{5}\end{array}$ \\
\hline $\begin{array}{l}\text { Autographa } \\
\text { califórnica } \\
\text { MNPV }\end{array}$ & $\begin{array}{l}\text { Autographa californica } \\
\text { Trichoplusia ni } \\
\text { Pseudoplusia includens } \\
\text { Heliothis virescens } \\
\text { Spodoptera exigua } \\
\text { Estigmene acrea } \\
\text { Plutella xylostella } \\
\end{array}$ & $\begin{array}{l}\text { Alfalfa, } \\
\text { Cultivos } \\
\text { hortícolas }\end{array}$ & VPN-ULTRA & Guatemala & Agricola E1 Sol \\
\hline $\begin{array}{l}\text { Spodoptera sunia } \\
\text { NPV }\end{array}$ & Spodoptera spp. & Hortícolas & VPN 82 & Guatemala & Agricola El Sol \\
\hline $\begin{array}{l}\text { Cydia pomonella } \\
\mathrm{GV}\end{array}$ & $\begin{array}{l}\text { Cydia pomonella, } \\
\text { Grapholita molesta }\end{array}$ & $\begin{array}{l}\text { Manzana, pera, } \\
\text { nogal, durazno. }\end{array}$ & $\begin{array}{l}\text { Carpovirus Plus } \\
\text { Madex } \\
\text { Carpovirusine } \\
\text { Madex Twin }\end{array}$ & $\begin{array}{l}\text { Argentina } \\
\text { Chile } \\
\text { Uruguay }\end{array}$ & $\begin{array}{l}\text { INTA-Arysta Life Science } \\
\text { Agricheck SRL.- Andermatt } \\
\text { Biocontrol } \\
\text { Arysta Life Science } \\
\text { Andermatt Biocontrol }\end{array}$ \\
\hline Erinnyis ello GV & Erinnys ello & $\begin{array}{l}\text { Mandioca } \\
\text { Caucho }\end{array}$ & Baculovirus erinnyis & $\begin{array}{l}\text { Brasil } \\
\text { Colombia } \\
\text { Colombia }\end{array}$ & $\begin{array}{l}\text { Empresa de Pesquisa } \\
\text { Agropecuária e Extensão Rural } \\
\text { de Santa Catarina S.A. } \\
\text { (EPAGRI) } \\
\text { BioCaribe SA } \\
\text { CORPOICA }\end{array}$ \\
\hline $\begin{array}{l}\text { Helicoverpa zea } \\
\text { SNPV }\end{array}$ & $\begin{array}{l}\text { Heliothis and } \\
\text { Helicoverpa spp. }\end{array}$ & $\begin{array}{l}\text { Maiz, tomate, } \\
\text { algodón, tabaco }\end{array}$ & Gemstar & $\begin{array}{l}\text { México } \\
\text { Brasil }\end{array}$ & Certis USA. \\
\hline $\begin{array}{l}\text { Phthorimaea } \\
\text { operculella } \mathrm{GV}\end{array}$ & $\begin{array}{l}\text { Phthorimaea operculella } \\
\text { Tecia solanivora }\end{array}$ & Papa & $\begin{array}{l}\text { Baculovirus } \\
\text { Corpoica } \\
\text { PTM baculovirus }\end{array}$ & $\begin{array}{l}\text { Colombia } \\
\text { Perú } \\
\text { Costa Rica }\end{array}$ & $\begin{array}{l}\text { CORPOICA } \\
\text { SENASA Perú } \\
\text { INTA Costa Rica }\end{array}$ \\
\hline $\begin{array}{l}\text { Phthorimaea } \\
\text { operculella } \mathrm{GV}+ \\
\text { Bacillus } \\
\text { thuringiensis }\end{array}$ & $\begin{array}{l}\text { Phtorimaea operculella } \\
\text { Tecia solanivora } \\
\text { Symmetrischema } \\
\text { tangolias }\end{array}$ & Papa & $\begin{array}{l}\text { Matapol Plus } \\
\text { Bacu-Turin }\end{array}$ & $\begin{array}{l}\text { Bolivia } \\
\text { Ecuador }\end{array}$ & $\begin{array}{l}\text { PROINPA Fund. } \\
\text { INIAP, Ecuador }\end{array}$ \\
\hline $\begin{array}{l}\text { Spodoptera albula } \\
\text { NPV }\end{array}$ & $\begin{array}{l}\text { Autographa californica } \\
\text { Trichoplusia ni } \\
\text { Pseudoplusia includens } \\
\text { Heliothis virescens } \\
\text { Spodoptera exigua } \\
\text { Estigmene acrea } \\
\text { Plutella xylostella } \\
\end{array}$ & $\begin{array}{l}\text { Alfalfa, } \\
\text { hortícolas, } \\
\text { vegetales }\end{array}$ & VPN-ULTRA & Guatemala & Agrícola E1 Sol \\
\hline $\begin{array}{l}\text { Spodoptera } \\
\text { exigua NPV }\end{array}$ & Spodoptera exigua & $\begin{array}{l}\text { Tomate, } \\
\text { pimiento, } \\
\text { berenjena }\end{array}$ & SPOD-X LC & México & $\begin{array}{l}\text { Certis U.S.A. - SUMMIT } \\
\text { AGRO Mexico }\end{array}$ \\
\hline $\begin{array}{l}\text { Spodoptera } \\
\text { frugiperda } \mathrm{MNPV}\end{array}$ & Spodoptera frugiperda & Maíz, sorgo & & Brasil & EMBRAPA \\
\hline
\end{tabular}

Tabla 1.1. Algunos ejemplos de bioinsecticidas basados en baculovirus aplicados en Latinoamérica.

\subsubsection{Los cuerpos de oclusión (OB)}

Entre las estrategias desarrolladas por los virus para mantener un reservorio genético que permita la subsistencia de la especie, las más difundidas consisten en permanecer en estado de latencia dentro del huésped e infectar una especie huésped de reserva. Sin embargo, estas estrategias no resultan adecuadas para los baculovirus, debido al limitado tiempo de vida del huésped, su población estacional y cíclica y a los profundos cambios fisiológicos que tienen lugar en el ciclo de vida del insecto. 
Los mecanismos de evolución y selección natural han resultado en los baculovirus en el desarrollo de capacidad de ocluir sus viriones en cristales de proteína, conformando cuerpos de oclusión (OB: occlusion bodies). Esta adaptación les permite permanecer en estado de latencia en el ambiente conservando su viabilidad durante un tiempo prolongado. De esta manera, los baculovirus pueden sobrevivir aunque no exista una población de insectos de densidad suficiente para transmitirlo.

\subsubsection{Clasificación y nomenclatura de los baculovirus}

En los comienzos del estudio de la familia Baculoviridae, se reconoció que, en base a la morfología de los OBs, era posible distinguir dos grupos o géneros de baculovirus: Nucleopoliedrovirus (NPV) y Granulovirus (GV).

Ambos grupos presentan una forma de cuerpo de oclusión, visible al microscopio óptico. Los OB de los NPV resultan fácilmente distinguibles, debido que presentan una estructura más grande y refringente. Los $\mathrm{OB}$ de los GV aparecen como gránulos oscuros que son más difíciles de distinguir. Debido a ello los OB de los NPV se conocen como poliedros y los de los GV se denominan gránulos. En correspondencia con esta denominación, la principal proteína que compone los OB de los NPV se llama poliedrina y la que compone los OB de los GV, granulina.

En el OB de un NPV se ocluyen muchos ODV (ODV: occlusion derived virus o virus derivados del cuerpo de oclusión, ver más adelante). En cambio, un único ODV es ocluido en el OB de un GV (Figura 1.4). A su vez, en los NPV, un único ODV puede contener varias o una única nucleocápside, distinguiéndose de esta forma los NPV múltiples (MNPV) y simples (SNPV).

Posteriormente, alineamientos de secuencias nucleotídicas de poliedrina de los baculovirus condujeron a la clasificación de dos grupos de NPV divergentes (Zanotto et al, 1993; Pearson y Rohrmann, 2002). Estos grupos se correlacionan con el tipo de proteína de fusión activa que se encuentra presente en la membrana del virión brotado (BV: budded virus, ver más adelante) y permite la brotación e ingreso esta forma viral en la célula. Los NPV del grupo II conservan una proteína fusogénica (F) ancestral activa y los del grupo I poseen una proteína fusogénica adquirida posteriormente (GP64) que ha reemplazado a la anterior. 
Poliedro de

nucleopoliedrovirus múltiple

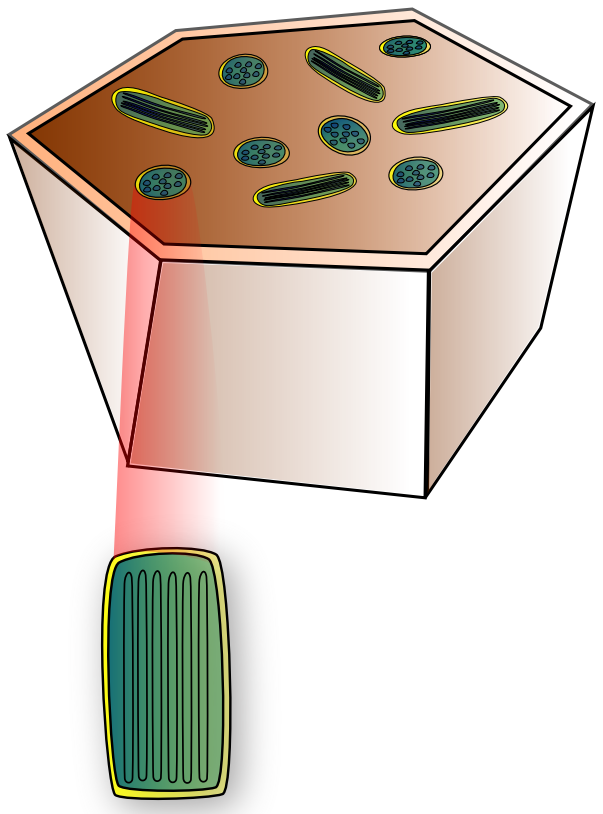

ODV de MNPV
Poliedro de nucleopoliedrovirus simple

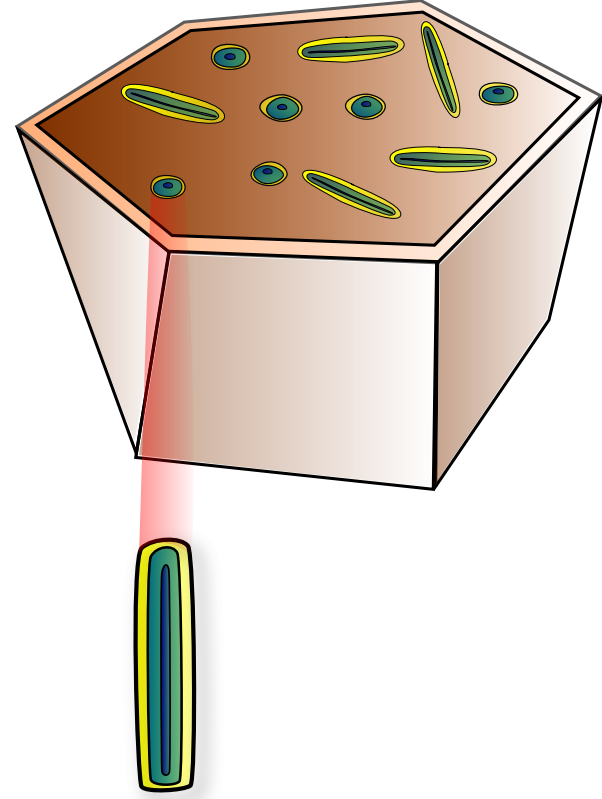

ODV de SNPV
Gránulo de granulovirus

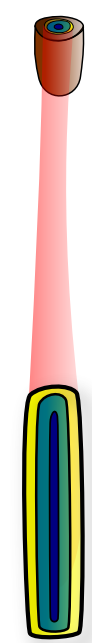

ODV de GV

Figura 1.4. Esquemas de los tres principales tipos de viriones de ODV. Los OB de GV tienen forma granular y contienen un único virión, en tanto que los OB de NPV, mucho más grandes que los primeros, son poliedros que contienen múltiples ODV. Los NPV se dividen, a su vez, en NPV múltiples y simples, de acuerdo al número de nucleocápsides encontradas en cada ODV.

La información aportada por la creciente cantidad de genomas de baculovirus secuenciados condujo a la reformulación de la clasificación taxonómica de los baculovirus (Jehle et al, 2006; Herniou et al., 2011) (Figura 1.5), en la cual se discriminan cuatro géneros: Alphabaculovirus (NPV específicos de lepidópteros), Betabaculovirus (GV específicos de lepidópteros), Gammabaculovirus (NPV específicos de himenópteros) y Deltabaculovirus (NPV específicos de dípteros). En esta clasificación, por lo tanto, se toma como parámetro evolutivo del género la especialización por un hospedador determinado. 


\subsubsection{Origen de los baculovirus}

Los artrópodos, predecesores de los insectos, estuvieron entre los primeros organismos en aventurarse habitar el ambiente terrestre cuando la vida aún se desarrollaba principalmente en el mar. Esto ha permitido que los insectos evolucionaran durante unos 400 millones de años y de la misma manera lo han hecho sus virus. La especificidad y complejidad de la interacción entre los baculovirus y los insectos sugiere un profundo vínculo evolutivo. Se ha propuesto, de hecho, que los baculovirus han coevolucionado con el orden Lepidoptera (Zanotto et al., 1993), en base a la especificidad encontrada entre los baculovirus de lepidópteros y a su elevada complejidad en relación a otros baculovirus, como los que fueron aislados de órdenes como Diptera y Hymenoptera (Afonso et al., 2001; Garcia-Maruniak et al., 2004; Herniou et al., 2003; Lauzon et al., 2004).

\subsubsection{Estructura de los cuerpos de oclusión (OB)}

Rodeando los cuerpos de oclusión de los NPV y GV se encuentra una red multicapa de glicoproteínas denominada cáliz (Carstens et al., 1992; Whitt y Manning, 1988), membrana poliédrica (Adams y McClintock, 1991) o envoltura poliédrica (Gross y Rohrmann, 1993; Gross et al., 1994; Russell y Rohrmann, 1990). La envoltura poliédrica (PE: del inglés Polyhedral Envelope) es relativamente porosa y es bastante diferente a la envoltura de bicapa lipídica convencional (Adams y McClintock, 1991; Robertson et al., 1974). La PE es una matriz de proteínas y carbohidratos que forma una red con poros hexagonales cuyo diámetro varía entre 6 a 15 nm (Adams y McClintock, 1991; Harrap, 1972).

La PE constituye la estructura que separa físicamente los OB de su entorno, protegiendo su integridad durante y después de la liberación al ambiente. Por ejemplo, los baculovirus son capaces de sobrevivir aun cuando un predador consume al insecto infectado gracias a la protección que provee la PE frente a las proteasas y glicosidasas digestivas (Abbas y Boucias, 1984). 


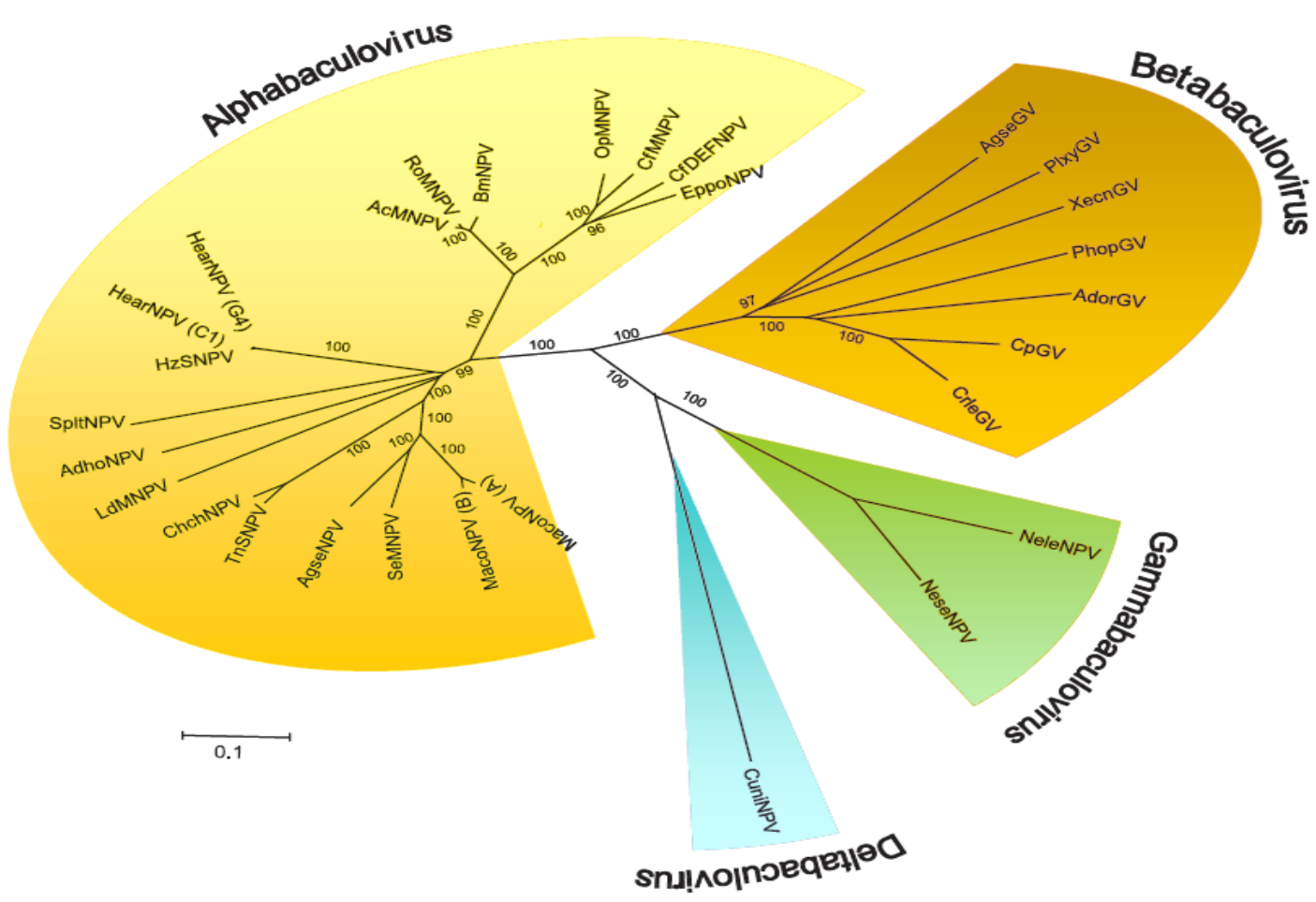

Figura 1.5. Esquema de la nueva clasificación taxonómica de la familia Baculoviridae, en base a la información filogenética surgida recientemente. Adaptado de Jehle et al., 2006.

\subsubsection{Ciclo infectivo de los baculovirus}

Los baculovirus se replican exclusivamente en insectos en etapa larvaria. La transmisión ocurre por vía oral, cuando una larva consume alimento contaminado por OB. Los OB y las partículas de alimento se transportan a través del intestino próximo y medio (Figura 1.6). Los lepidópteros poseen $\mathrm{pH}$ alcalino en el intestino ( $\mathrm{pH} 10$ a 11) y los baculovirus han evolucionado para tolerar y explotar este microambiente extremo (Terra y Ferreira, 1994). La alcalinidad del medio desencadena la disolución de los OB liberando ODV en la luz intestinal (Adams y McClintock, 1991).

Para tener acceso a las células epiteliales del intestino medio, los ODV deben superar la barrera de la membrana peritrófica (PM). La membrana peritrófica es una matriz de quitina y proteínas que tapiza y protege al intestino medio del contacto directo con el alimento. 
Los baculovirus han desarrollado estrategias para debilitar la membrana peritrófica. Una de ellas consiste en la liberación de proteínas denominadas enhancins previamente empaquetadas dentro de los cuerpos de oclusión (Greenspan et al., 1991; Hashimoto et al., 1991; Hotchkin, 1981; Lepore et al., 1996; Ohba y Tanada, 1983; Wang et al., 1994) o presentes en la superficie de los ODV (Slavicek y Popham, 2005). Se trata de metaloproteasas que pueden llevar a la degradación hidrolítica de las proteínas MLK (mucin like proteins) que unen las unidades de quitina de la membrana peritrófica. Existen además otros factores virales que debilitan la membrana peritrófica (Derksen y Granados, 1988).

Una vez que los ODV han penetrado en el espacio ectoperitrófico se unen de manera específica a los microvilli de las células columnares que componen el epitelio del intestino medio del insecto (Adams y McClintock, 1991). Se produce luego la fusión de la bicapa lipídica del ODV con la membrana celular, liberándose de esta manera la nucleocápside al citoplasma celular (Haas-Stapleton et al., 2004; Horton y Burand, 1993). Las nucleocápsides se trasladan hacia el núcleo donde son desensambladas y se libera el genoma del virus. A partir de este momento se expresan los genes virales dando lugar a la aparición de progenie viral.

A pesar del alto grado de especificidad con el cual los baculovirus invaden las células columnares del epitelio intestinal medio del insecto (infección primaria), este tejido no resulta uno de los más convenientes en relación a los objetivos de alto nivel de replicación del virus, debido a que las células epiteliales se desprenden con frecuencia (Engelhard y Volkman, 1995), tienen predisposición a la apoptosis (Uwo et al., 2002) y su ciclo celular se encuentra detenido. Por esta razón, en la mayoría de los casos, el curso de la infección de los baculovirus continúa en tejidos internos que se dividen activamente (infección secundaria), lo que permite alcanzar niveles de progenie elevados. Parte del ciclo de infección involucra la formación de un nuevo fenotipo viral: el virión brotante (BV: budded virus).

Los BV son producidos por las células del epitelio columnar y liberados a la lámina basal, que representa el primer obstáculo en la dispersión del virión hacia los tejidos internos. Para superar esta barrera, los BV cuentan con la colaboración de catepsinas virales (VCATH) (Lanier y Volkman, 1998; Nomura y Katunuma, 2005; Yamaguchi et al., 1990) y 
proteasas codificadas por las células columnares probablemente involucradas en la degradación de la lámina basal.

(a)

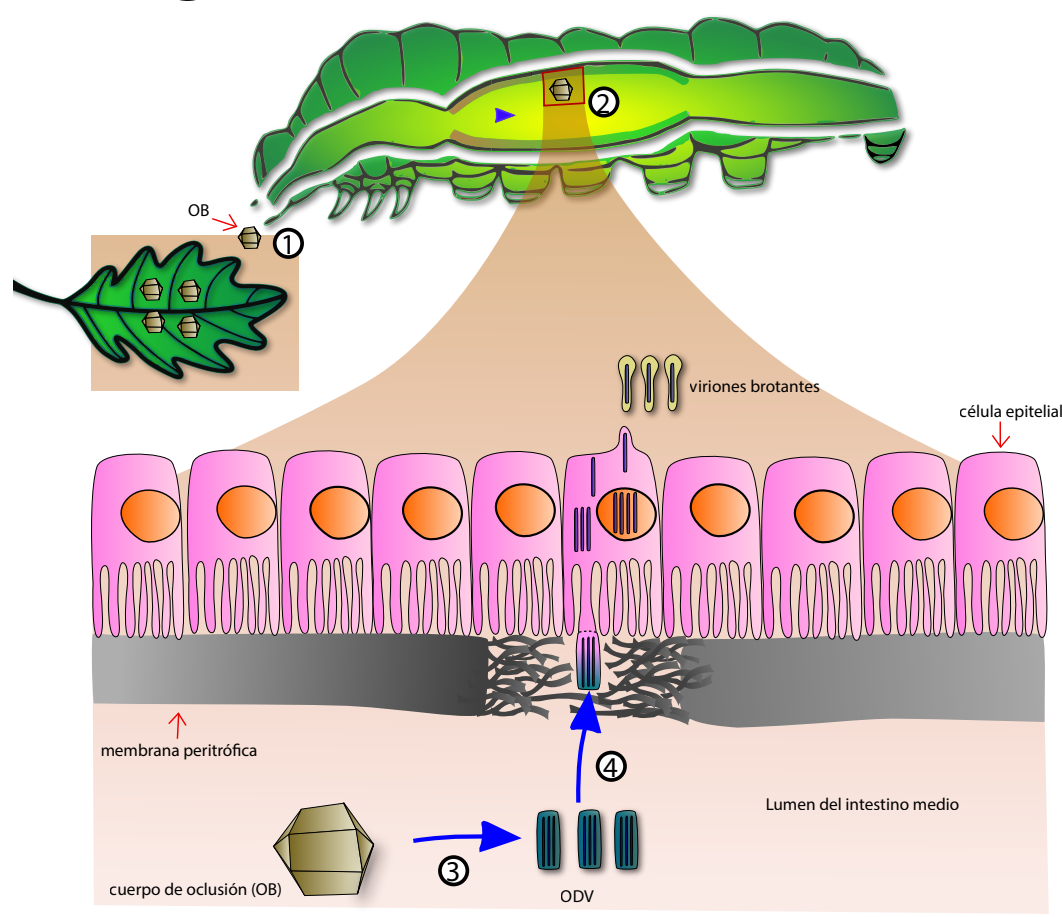

(b)

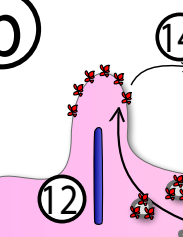<smiles></smiles>

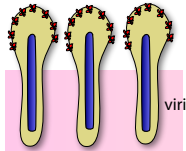

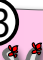
औ

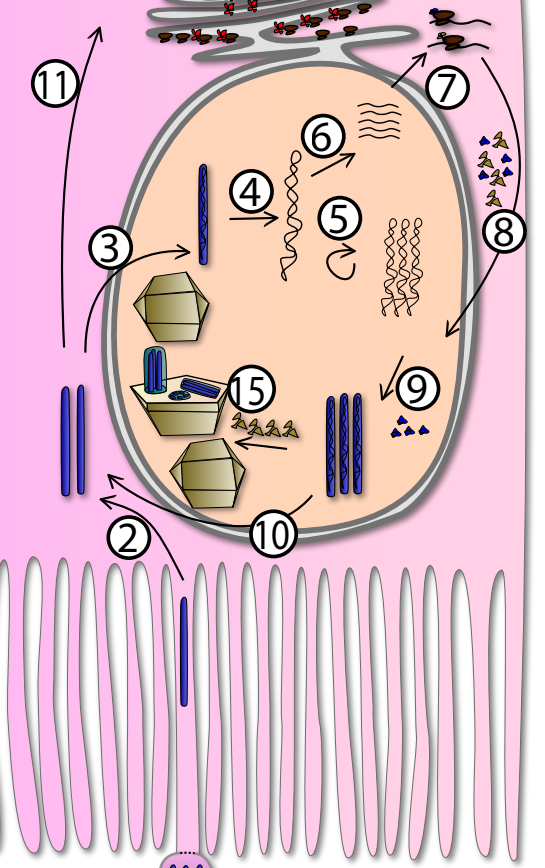

(1)

Figura 1.6. a) Representación seccional de una larva de lepidóptero. Un cuerpo de oclusión (OB) presente en el ambiente es ingerido por la larva comenzando un nuevo ciclo de infección (1). Cuando el OB alcanza el intestino medio (2) se disuelve en el medio alcalino, liberando ODV (3). La membrana peritrófica, que protege a las células epiteliales del contacto directo con el contenido intestinal, es degradada por la acción de proteínas codificadas por el virus y la célula hospedadora presentes en el OB (4), permitiendo el ingreso de los ODV en las células (5). b) Representación del ciclo de vida de un baculovirus. Los ODV ingresan en la célula a través de la fusión con las microvellosidades (1), liberando las nucleocápsides (NC) en el citoplasma (2). Las NC pueden ingresar en el núcleo (3) donde se desensamblan liberando el genoma viral (4). De esta forma los genes tempranos del virus son transcriptos (6) y traducidos en complejos ribosomales en el citoplasma (7). Algunos productos de estos genes traslocan al núcleo para participar en la replicación viral (5), la transcripción de los genes tardíos (6) y el ensamblado de nuevas NC (9). En las primeras etapas de la infección, las NC son transportadas al citoplasma (10) y emergen de la célula por brotación de la membrana citoplasmática basolateral (11) (12) en forma de viriones brotantes (14) en las regiones donde se acumula la proteína de fusión viral (13), previamente expresada y direccionada por la ruta secretoria. En la etapa tardía de la infección, en cambio, las NC son envueltas en el núcleo y ocluidas en la matriz proteica de poliedrina (15). 
Si la barrera de la lámina basal es superada, los BV pueden acceder libremente a traqueoblastos (Engelhard et al., 1994; Kirkpatrick et al., 1994; Washburn et al., 1995), hemocitos y células del cuerpo graso, favorables para la proliferación del virus y la producción de OB.

Para finalizar el ciclo de vida, la producción de grandes cantidades de poliedros no resulta aún suficiente para asegurar la diseminación adecuada del virus, debido a que éstos se encuentran restringidos al interior del organismo infectado. Aunque la predación y el canibalismo de las larvas constituyen mecanismos de transmisión importantes, los baculovirus han desarrollado proceso más eficiente que consiste en la licuefacción y rotura de cutícula de la larva infectada, favorecidos por la acción sinérgica de catepsinas (CATH) (Ohkawa, et al., 1994; Slack, et al., 1995) y quitinasas virales (CHI-A) (Hawtin et al., 1997). De esta manera los OB son ampliamente dispersados sobre la superficie del alimento que es ingerido por un nuevo hospedador.

\subsubsection{Ciclo infectivo de los baculovirus y fenotipos virales}

\section{Fase temprana}

El ciclo de vida de los baculovirus incluye una etapa no lítica, en la cual se producen BV, seguido de una etapa de producción de ODV, que finaliza con la oclusión y la liberación lítica de los OB.

Los diferentes eventos del ciclo infectivo ocurren de acuerdo a un orden cronológico establecido, característico de cada virus. En el baculovirus modelo AcMNPV, los genes tempranos se expresan unos 30 minutos luego del comienzo de la infección (Chisholm y Henner, 1988) y los productos codificados, en colaboración con las proteínas asociadas al virión, interaccionan con la célula hospedadora para permitir la replicación del DNA viral. De esta manera, la estructura del núcleo comienza a expandirse (durante las primeras 6 horas), con la formación de una estructura irregular, de apariencia granulosa y alta densidad electrónica (Harrap, 1972; Young et al., 1993). Esta región se denomina estroma virogénico y es el sitio donde tiene lugar la transcripción del RNA viral, la replicación del DNA y el ensamblado de la nucleocápside. A su vez, ocurre un desplazamiento de la heterocromatina hacia el borde del núcleo (Williams y Faulkner, 1997). A las 12 horas de la infección, el 
estroma virogénico ocupa la mayor parte del núcleo. A partir de ese punto comienza la liberación de los viriones brotantes (BV), que resultan de la envoltura de las nucleocápsides con la membrana plasmática del hospedador. La bicapa lipídica que rodea los BV contiene, por lo tanto, proteínas de membrana del hospedador además de las proteínas codificadas por el genoma viral. En las células columnares del intestino medio, las nucleocápsides presentan polaridad basal (Keddie, et al., 1989).

\section{Los viriones brotantes}

Los viriones brotantes contienen una única nucleocápside, envuelta de una manera espaciosa. La envoltura del BV puede contener alguna de las dos glicoproteínas mayoritarias, GP64 o GP67 (Whitford et al., 1989) y/o la proteína de fusión EFP o F (Lung et al., 2002; Pearson et al., 2000; Pearson, et al, 2001; Westenberg et al., 2004; Westenberg et al., 2002; IJquel et al., 2000). Estas proteínas se encuentran implicadas en la brotación y en el reconocimiento y la entrada de los BV en las células del hospedador (Blissard y Wenz, 1992; Hefferon et al., 1999; Oomens y Blissard, 1999). La proteína GP64 se encuentra presente únicamente en los NPV del grupo I, mientras que en este grupo la proteína $F$, aunque presente, ha perdido aparentemente las funciones asociadas a la envoltura del virión (Whitford et al., 1989). En cambio, en los NPV del grupo II (y posiblemente en los GV) la EFP desempeña las funciones descriptas para la GP64 (Bulach et al., 1999; Hashimoto et al., 2000; Hayakawa et al., 1999; Herniou et al., 2001; Lange y Jehle, 2003; Luque et al., 2001; Slack et al., 2004; Wormleaton et al., 2003; Zanotto, et al., 1993).

\section{ODV: viriones derivados de los cuerpos de oclusión}

Unas 20 horas después de iniciado el ciclo infectivo el estroma virogénico sufre una retracción y tiene lugar la producción de ODV. El anillo nuclear se expande y el espacio es ocupado por nuevas nucleocápsides que luego, en el mismo núcleo, adquieren una envoltura lipídica para convertirse en ODV. Es comprensible, por lo tanto, que la estructura de la bicapa perteneciente a los ODV guarde cierta relación con la membrana nuclear interna en cuanto a su composición lipídica (Braunagel \& Summers, 1994). La membrana de los ODV, al igual que la de los BV, contiene varias proteínas virales integrales y asociadas (Figura 1.7). 
La aparición de ODV en la zona anular del núcleo es seguida rápidamente de una etapa de oclusión, que finaliza con la liberación lítica de los $\mathrm{OB}$, a las 48 horas post infección. La proteína viral CATH, mencionada anteriormente por su rol en el proceso de licuefacción del hospedador también resulta crítica para la lisis celular. P10, capaz de formar cuerpos fibrilares en el núcleo y el citoplasma también estaría implicada en la liberación de OB de la célula hospedadora (Williams et al., 1989).

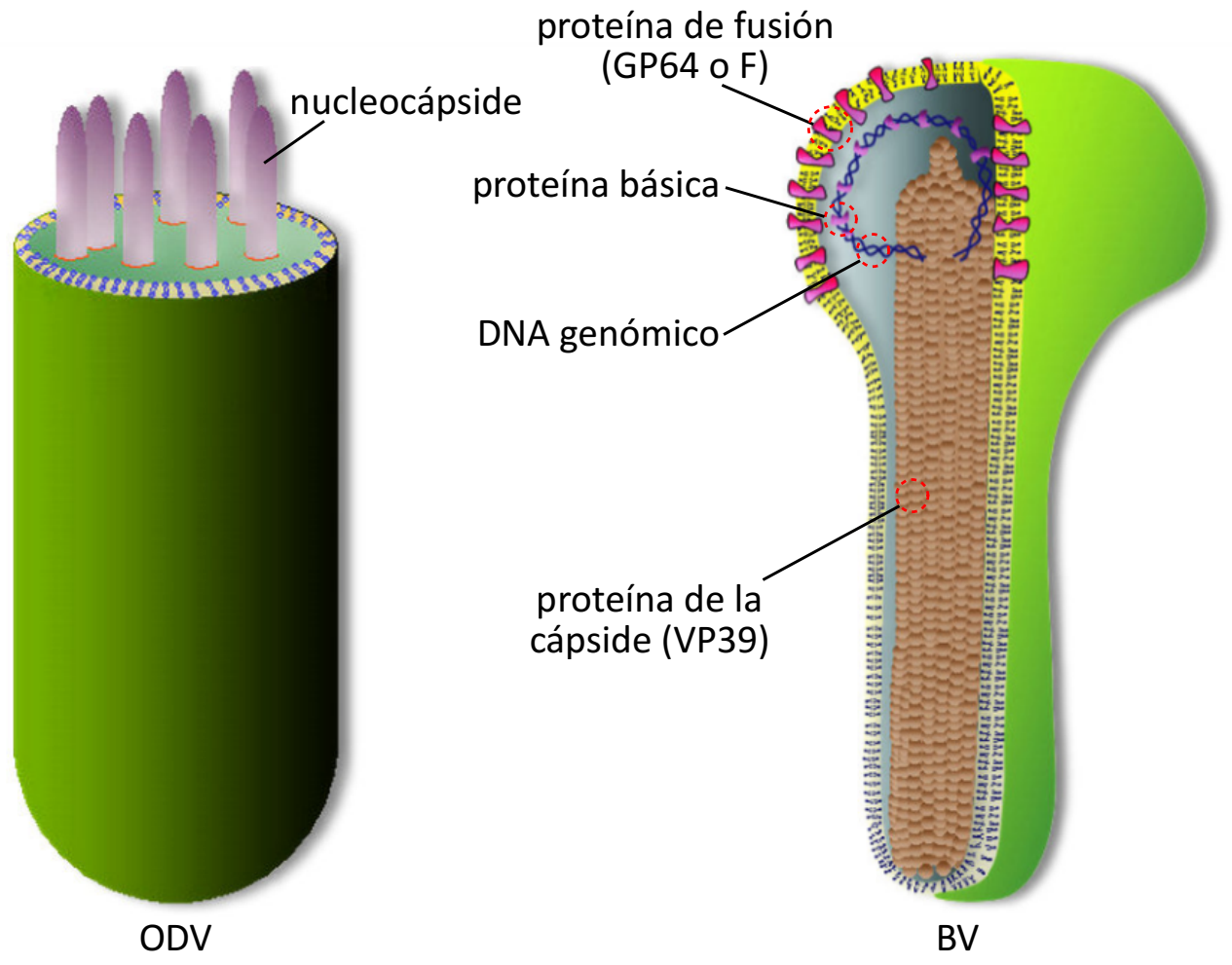

Figura 1.7. Esquema de los dos principales fenotipos de un MNPV: ODV (Oclussion derived virion) y BV (Budded virion). Los ODV son estructuras especializadas en la invasión del epitelio intestinal, contienen varias nucleocápsides por virión y su envoltura guarda una relación muy estrecha con la de la membrana nuclear interna de las células hospedadoras. Los BV surgen de la exocitosis de nucleocápsides a través de la membrana plasmática de las células infectadas y se especializan en la invasión de tejidos internos. Los BV contienen una única nucleocápside y poseen una región peplomérica en la cual se encuentra la proteina de fusión (GP64 en NPV grupo I y proteína F en NPV grupo II y GV), implicada en el proceso de fusión y endocitocis del BV. La estructura de la nucleocápside es muy similar en ambos viriones, compuesta mayoritariamente por las proteínas VP39, P80 y P24. En la nucleocápside se encuentra el genoma viral asociado principalmente con la proteína básica de unión al DNA $(p 6,9)$. [Nota: los esquemas de ODV y BV no se presentan en la misma escala y no se detallan las diferentes proteínas estructurales] 


\subsubsection{Estructura de las nucleocápsides y funciones de la proteína PP78/83 (1629)}

Las nucleocápsides de los ODV y BV son muy similares debido a que ambas contienen genomas virales completos y comparten las proteínas estructurales mayoritarias. Las nucleocápsides son polares: poseen una base en un extremo y una estructura apical tipo capuchón en el otro. Además de la proteína estructural mayoritaria de la nucleocápside, denominada VP39, existen varias proteínas minoritarias pero esenciales asociadas a la cápside. Entre ellas, se encuentra la proteína PP78/83 (ORF 1629) (Pham et al., 1993). La proteína 1629 se encuentra asociada con la base de las nucleocápsides (Russell y Rohrmann, 1997) y se supone que se encuentra involucrada en la translocación de la nucleocápside al núcleo (Lanier y Volkman, 1998), aunque tendría además otros roles.

\subsubsection{Regulación temporal de la expresión génica}

La regulación temporal de la expresión de los genes virales ha sido estudiada principalmente en el baculovirus modelo AcMNPV. En este virus la expresión tiene lugar en forma de cascada, en la cual la expresión de los genes en una etapa determinada requiere la presencia de los productos génicos de etapas anteriores. La expresión genética del baculovirus puede ser dividida en cuatro fases temporales: fase temprana inmediata, temprana retrasada, tardía y muy tardía (Tabla 1.2) (Rohrmann, 2013; Romanowski y Ghiringhelli, 2001).

\section{Genes tempranos}

Los genes tempranos pueden subdividirse en dos categorías: tempranos inmediatos y tempranos retrasados (genes $\alpha$ y $\beta$ ). Ambos son transcriptos por la RNA polimerasa II de la célula hospedante, sensible a la $\alpha$-amanitina.

Los genes $\alpha$ y $\beta$ difieren en sus promotores y en las secuencias activadoras a distancia (enhancers). Los genes tempranos inmediatos son expresados dentro de los $30 \mathrm{~min}$ postinfección una vez que el DNA viral ha alcanzado el núcleo (Chisholm y Henner, 1988). Los genes tempranos retrasados requieren de la unión de transactivadores virales (sintetizados previamente) a los enhancers para alcanzar niveles de expresión máximos. Los promotores de estos genes se asemejan a los promotores de genes del hospedante, 
tienen un motivo TATA box típico y un sitio de inicio de la transcripción CAGT que se ubica 25-31 pb downstream del motivo TATA box y son reconocidos por extractos nucleares de células no infectadas (Hoopes y Rohrmann, 1991). La secuencia CAGT está involucrada en la eficiencia del inicio de transcripción, probablemente influyendo sobre la afinidad por el factor de transcripción $\mathrm{TF}_{\|} \mathrm{D}$ (Pullen y Friesen, 1995).

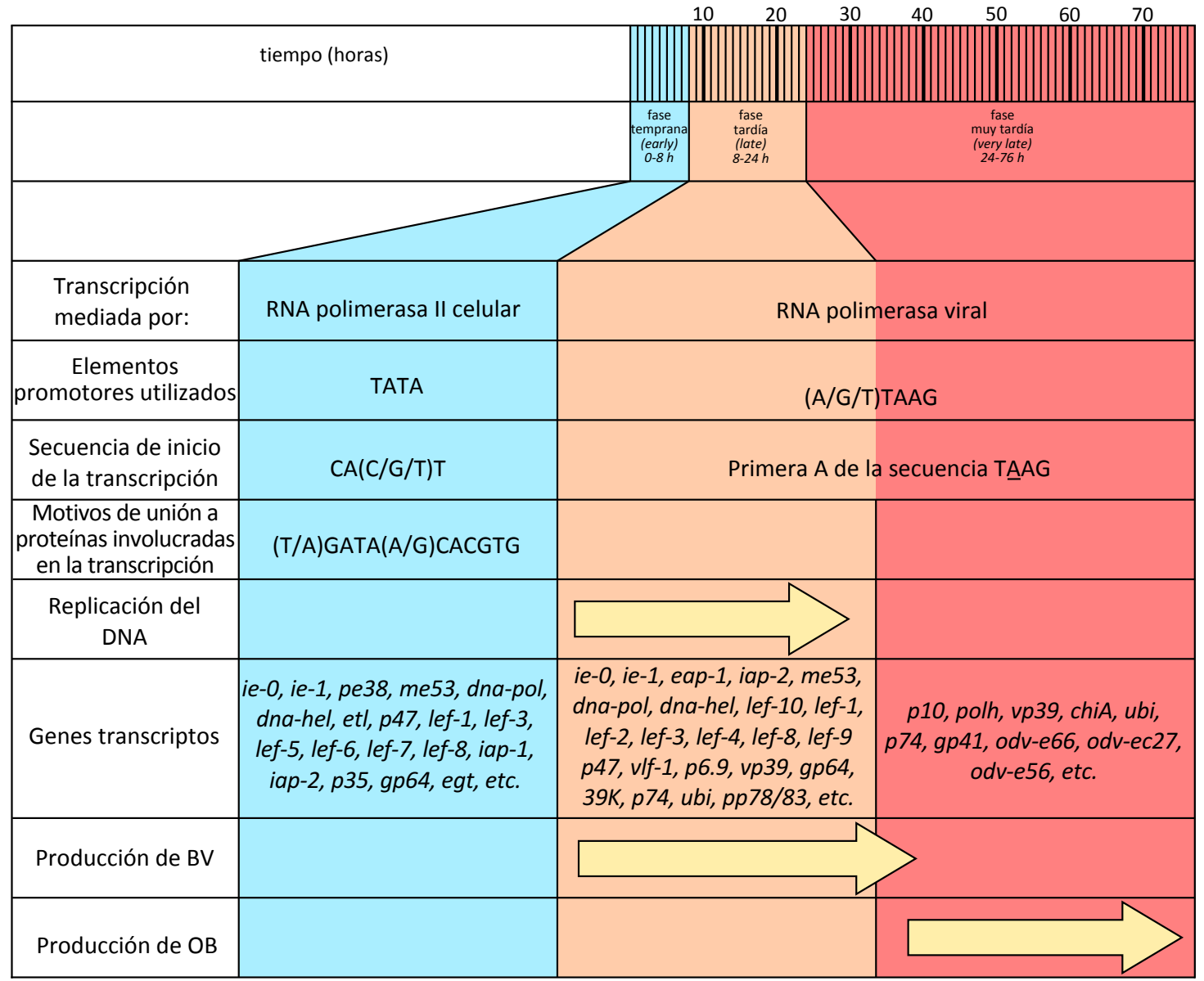

Tabla 1.2. Etapas en la infección con NPV. La expresión de los genes de los baculovirus ocurre en forma de cascada (factores codificados en una etapa son necesarios para el desarrollo en las etapas posteriores) y se di vide en tres etapas: temprana, tardía y muy tardía. La transcripción de genes tempranos depende de la RNA polimerasa celular, aunque con la excepción de los genes inmediatos, requiere de factores adicionales codificados por el virus. La replicación del DNA es un requisito para la expresión de genes tardíos y muy $\mathrm{t}$ ardíos, los cuales se transcriben utilizando la RNA polimerasa viral. En la etapa tardía se transcribe la mayoría de los genes estructurales de la nucleocápside y se liberan al medio viriones brotantes, mientras que en la etapa muy tardía se producen la mayoría de proteínas estructurales propias de los ODV y se ensamblan los cuerpos de oclusión. [Adaptado de: Romanowski, V. y Ghiringhelli, P.D.: "Biología molecular de los baculovirus. Replicación y regulación de la expresión génica", Capítulo V, En: "Los Baculovirus y sus aplicaciones como bioinsecticidas en el control biológico de plagas" P. Caballero, M. López-Ferber y T. Williams, eds.] 
En la fase temprana inmediata la transcripción es llevada a cabo por la RNA polimerasa II del hospedador. Los principales genes de fase temprana inmediata incluyen ie-1, ie-0 e ie-2 y subunidades de la polimerasa propia del baculovirus.

\section{Replicación}

La replicación del DNA se produce en el núcleo de la célula infectada, el virus expresa sus propios genes para este proceso durante la etapa temprana. Los elementos que actúan en cis requeridos para la replicación (origen de replicación u ori) han sido identificados por el análisis de genomas defectivos obtenidos luego de varios pasajes virales en cultivo de células de insecto (Kool et al., 1994; Lee y Krell, 1994) y por ensayos de replicación transitorios (Leisy y Rohrmann, 1993; Pearson y Rohrmann, 1995). La actividad de ori fue encontrada en los baculovirus por estar asociada con las regiones homólogas ( $h r$, por homologous region) (Lu y Miller, 1995a). Las hr contienen secuencias palindrómicas interespaciadas con repeticiones directas cortas capaces de formar estructuras secundarias y se encuentran dispersas a lo largo del genoma del baculovirus. Estas secuencias también pueden actuar como enhancers transcripcionales (Friesen, 1997). La presencia de las $h r$ es una característica común de los baculovirus, sin embargo no todo está aclarado acerca de ellos (Berretta y Romanowski, 2008). Además de los ori tipo $h r$, se identificaron secuencias no-hr con actividad ori mediante ensayos de replicación transitoria en los genomas del nucleopoliedrovirus de Orgia pseudotsugata (Pearson et al., 1993), de Autographa californica (Kool et al., 1994b), de Spodoptera exigua (Heldens et al., 1997) y de Spodoptera litura (Huang y Levin, 1999). Estos ori llamados de tipo no- $h r$ carecen de las secuencias palindrómicas o repeticiones encontradas en los ori tipo $h r$. Los ori no-hr de diferentes baculovirus no tienen homología estructural entre ellos ni semejanza con los ori tipo hr en el mismo genoma. Sin embargo, poseen elementos básicos que se encuentran en el consenso de los ori eucariotas tales como múltiples repeticiones invertidas y directas, palíndromes y secuencias ricas en AT (DePamphilis, 1993). A diferencia de los ori tipo $h r$, la presencia y distribución de motivos de estructura secundaria dentro de las secuencias ori no-hr es probablemente más importante para la actividad ori que la secuencia nucleotídica en sí misma. 
Los elementos que actúan en trans requeridos para la replicación del DNA baculoviral incluyen, entre otros, la DNA polimerasa viral (dnapol), p143 (helicasa), lef-1 (DNA primasa) y lef-2, cuatro genes que han sido encontrados en todos los baculovirus secuenciados hasta el momento (Herniou, 2003). Se han identificado cinco genes esenciales $(p 143, i e-1$, lef-1, lef-2, y lef-3) y cinco genes estimulantes de la replicación del DNA (dnapol, p35, ie-2, lef-7, y pe38) en AcMNPV (Crouch y Passarelli, 2002). En ensayos de replicación transitoria, los plásmidos que contienen $h r$ replican a una alta tasa (Leisy y Rohrmann, 1993). En otros estudios, un plásmido basado en pUC, sin ninguna secuencia viral ori, replica en células de insecto infectadas formando concatémeros y/o integrado en el genoma viral (Wu et al., 1999). Estas observaciones sugieren un mecanismo de replicación de DNA tipo círculo rodante, mientras Kool et al. (1995) sugieren una posible combinación de los mecanismos de círculo rodante y tipo theta. Oppenheimer y Volkman (1997) fueron capaces de detectar múltiples fragmentos de genoma de una unidad de longitud en proceso de replicación, sugiriendo que AcMNPV replica en una manera cabeza-cola vía un mecanismo de círculo rodante.

\section{Genes tardíos y muy tardíos}

Entre las 8 y 24 h. p. i. ocurre la transcripción y expresión de genes tardíos (o genes $\gamma$ ), la producción de proteínas estructurales y la formación de BV. Estos genes así como también los genes muy tardíos (o genes $\delta$ ) tienen un sitio de inicio de la transcripción invariante y universal (A/G/T)TAAG y son transcriptos por la RNA polimerasa codificada por el propio virus, la cual es insensible a la $\alpha$ amanitina. Además, en estudios de expresión transitoria se demostró que dieciocho genes de AcMNPV son esenciales para lograr niveles de expresión óptimos de un gen indicador bajo el control de promotores tardíos y muy tardíos (vp39, p6.9, polh, p10) (Lu y Miller, 1995b). En la fase tardía se expresan, entre otros, genes que codifican las proteínas estructurales dando comienzo a la etapa de ensamblaje de nucleocápsides (NC) en el núcleo de la célula infectada (Fraser, 1986).

La expresión génica muy tardía comienza alrededor de las 18-24 hpi (horas post infección) y se caracteriza por un dramático incremento de la transcripción y expresión de genes muy tardíos, y la reducción de la transcripción de genes tardíos. En los 
promotores muy tardíos, a diferencia de los tardíos, el nivel de expresión no depende del contexto inmediato en el que se encuentra la secuencia TAAG sino de una secuencia denominada burst sequence que se localiza entre el sitio de inicio de la transcripción y el codón de inicio de la traducción. En los promotores muy tardíos esta secuencia es rica en AT e influye en la actividad del promotor. Esta región interactúa con proteínas celulares, las cuales son imprescindibles para asegurar altos niveles de transcripción de genes tales como poliedrina ( $p o l h$ ) o granulina ( $g r a), p 10$ y otros que codifican proteínas necesarias para formar los cuerpos de oclusión (Braunagel et al., 1999). El producto del gen p10 está asociado con la formación de extensas estructuras fibrilares en el núcleo y citoplasma de células infectadas (Quant-Russell et al. 1987; Van der Wilk et al., 1987). También se ha sugerido que podría contribuir a la ruptura de la membrana nuclear y la liberación de los cuerpos de oclusión desde las células infectadas (van Oers et al., 1993; Williams et al., 1989). Dado que polh y p10 no son necesarias para la transmisión de baculovirus en cultivo celular y que se expresan en altos niveles durante la infección, sus promotores han sido utilizados para el desarrollo de vectores de expresión. La región codificante de estos genes puede ser reemplazada por genes exógenos que resultan en la producción de altos niveles de proteína de interés (Smith et al., 1983; Vlak et al., 1990).

\subsection{Control biológico de Anticarsia gemmatalis con el baculovirus AgMNPV}

En la década de 1970 se aisló un baculovirus (AgMNPV) de larvas de A. gemmatalis de diferentes regiones de Brasil (Allen y Knell, 1977; Carner y Turnipseed, 1977). Los experimentos iniciales con AgMNPV revelaron un alto potencial para su utilización en programas de MIP en cultivos de soja. Entre 1980 y 1982 se llevaron a cabo los primeros experimentos pilotos bajo la coordinación del Dr. Flavio Moscardi en 21 campos en el sur de Brasil, con virus obtenido a partir de la recolección de larvas infectadas en el campo.

El éxito subsecuente del programa de AgMNPV se debe en gran medida a la colaboración entre los investigadores del EMBRAPA (Empresa Brasileira de Pesquisa Agropecuária) y los extensionistas que persuadieron a los agricultores de los beneficios de optar por este 
tipo de control biológico. En esta etapa se organizaron charlas y otras actividades destinadas a difundir los resultados obtenidos.

Como los resultados de los ensayos piloto resultaron satisfactorios, en 1983 se decidió implementar un programa para la utilización de AgMNPV dirigido por EMBRAPA. En la etapa inicial, el virus era producido en larvas de $A$. gemmatalis criadas en laboratorio y luego se recolectaron larvas muertas de las áreas tratadas con este producto de donde se extraía más virus para tratar otros campos o para almacenar inóculo para las temporadas siguientes. Así se estableció un modelo de producción de AgMNPV en campo de bajo costo.

En 1986, se desarrolló una formulación de AgMNPV en forma de polvo humectable (Moscardi, 1989, 1999, 2007; Moscardi et al., 2011) y hacia finales de la década de 1980 EMBRAPA comenzó a negociar contratos para la transferencia de la producción de AgMNPV a empresas privadas. La comercialización de AgMNPV por parte de cinco compañías condujo a la producción de virus para tratar más de un millón de hectáreas en la temporada 1990-1991 y a dos millones en 2002-2003 (Sosa-Gómez et al., 2008; Szewczyk et al., 2009).

A pesar de que algunas compañías intentaron establecer métodos de producción del virus en laboratorio a través de la infección de larvas criadas en dieta artificial, esta metodología resultó más costosa que la producción en campo debido al alto precio del trabajo, el material descartable y los componentes de la dieta artificial (Moscardi, 2007). Por otro lado, la producción de virus en campo posee varias desventajas relacionadas con la variabilidad en los rendimientos que dependen de la prevalencia natural de la larva y la calidad de la recolección. Estos problemas se profundizaron cuando, en virtud de la demanda creciente de bioinsecticida, se reemplazó la recolección manual por métodos automatizados. El material recolectado por estos medios fue de menor calidad, incluyendo otros insectos y restos, resultando en una formulación que no logró ejercer una protección adecuada de los cultivos.

Posteriormente, se optimizaron los costos del proceso de producción de AgMNPV en laboratorio (Santos, 2003). De esta forma se consiguieron rendimientos económicos semejantes a los de la producción en campo. La compañía Codetec adaptó este método 
de producción, contando con un potencial de producción adecuado para tratar unos 2 millones de hectáreas de cultivo.

Con la introducción de los mecanismos de siembra directa en los cultivos de soja de Brasil, muchos productores adquirieron paquetes tecnológicos de las grandes compañías agropecuarias que recomiendan la aplicación conjunta de herbicidas y plaguicidas a las malezas. Esta práctica tuvo como consecuencia una reducción de las poblaciones de organismos que son enemigos naturales de especies dañinas y potenciales plagas (Corrêa-Ferreira et al., 2010). De esta forma, muchas especies que antes causaban poco daño se convirtieron en plagas (Bueno et al., 2007), lo cual derivó en una reducción significativa del uso de AgMNPV Brasil, siendo aplicado actualmente a sólo 200.000 hectáreas por año (Sosa-Gómez, D.R., comunicación personal).

El virus también ha sido incorporado con éxito en Paraguay desde la década de 1990 (Kokubu, 1994), donde actualmente se aplica en unas 100.000 hectáreas por año.

\subsection{Granulovirus de Epinotia aporema}

Epinotia aporema (Lepidoptera: Tortricidae) es plaga en cultivos de leguminosas de interés agronómico, tales como soja, poroto, maní, lenteja, garbanzo y alfalfa. Se encuentra distribuida en zonas templadas de Centro y Sudamérica. Se aisló un virus de la granulosis (EpapGV) de larvas de Epinotia aporema (barrenador de brotes) y se realizó su caracterización biológica, bioquímica y morfológica (Sciocco-Cap et al., 2001, Goldberg et al., 2002). En particular, se verificó que EpapGV es un virus poliorganotrópico (GV tipo II) y de acción relativamente rápida, características que lo convierten en un muy buen candidato para el control biológico del barrenador de brotes. Más recientemente, se secuenció y caracterizó su genoma completo (Ferrelli et al., 2012).

\subsection{Mejoramiento genético de baculovirus para el control biológico de plagas}

Diversos miembros de la familia Baculoviridae son utilizados como agentes de control biológico con excelentes resultados (Moscardi, 1999; Inceoglu et al., 2001; Haase et al., 
2013). Sin embargo, la aplicabilidad de algunas especies en el manejo de plagas agrícolas ha sido limitada por su lenta velocidad de acción y estrecho rango de huéspedes.

Se ha buscado mejorar la velocidad de acción de los baculovirus mediante el desarrollo de baculovirus genéticamente modificados. Las estrategias más exploradas hasta el momento consisten en la interferencia de la fisiología de la larva hospedante, la introducción de toxinas específicas de insecto (Bonning y Hammock, 1996; Mishra, 1998; Inceoglu et al., 2001) y la expresión de genes que colaboran con la degradación de la membrana peritrófica (MP) de la larva (Lima et al., 2013). Entre estos genes, la toxina TxP-I del ácaro Pyemotes tritici es uno de los candidatos más prometedores (Lu, et al., 1996; Burden et al., 2000). Esta toxina actúa sobre los canales de calcio dependientes de voltaje (VDCC: voltage-dependent calcium channels) de las neuronas de artrópodos, ocasionando parálisis. La incorporación de esta toxina en el genoma del baculovirus modelo AcMNPV (virus de la poliedrosis nuclear múltiple de Autographa californica) condujo a una disminución de tiempo de muerte de un $30 \%$ a un $60 \%$, dependiendo del tipo de promotor seleccionado (Lu et al., 1996). Se ha demostrado que además no ocasiona ningún efecto en ratones al inyectarse por vía intracerebral o intraperitoneal.

Recientemente se ensayó una toxina de araña muy prometedora que aún no se ha probado en el contexto de un bioinsecticida baculoviral (Nakasu, et al., 2014).

La mayoría de los baculovirus poseen en su genoma genes que codifican proteínas que intervienen en la degradación de la membrana peritrófica, contribuyendo a una invasión efectiva del tejido epitelial del intestino medio. Entre estos genes se encuentran las catepsinas virales ( $v$-cath), las quitinasas (chiA) y gp37. Una de las características más llamativas de AgMNPV es que no posee ninguno de estos genes. Aunque se supone que en los cuerpos de oclusión de este virus existen otras proteínas que reemplazan las actividades de los genes mencionados, se planteó la hipótesis de que la introducción de v-cath, chiA y gp37 en el genoma de AgMNPV podría aumentar la velocidad de infección del virus. Recientemente se generó un AgMNPV recombinante que expresa los genes de v-cath y chiA de CfDEFNPV, resultando en una disminución moderada del tiempo letal medio (LT50) (Lima, et al., 2013). En algunos baculovirus los genes de v-cath y chiA se encuentran adyacentes al gen de gp37 (Ferrelli et al., 2012). Este último codifica una proteína (GP37) homóloga a las fusolinas bacterianas que posee un dominio de unión a 
quitina (CBD). En bacterias, se demostró que existe una relación funcional entre las fusolinas y la quitinasa (Vaaje-Kolstad et al,. 2005): mediante la interacción con quitina las fusolinas facilitan la degradación de la quitina por parte de las quitinasas. Considerando que esta interacción aún no ha sido demostrada para los genes de baculovirus, resulta de interés la inserción de estos tres genes (gp37, chiA y v-cath) en el genoma de AgMNPV. Además, algunos baculovirus codifican genes denominados enhancins (enh) o viral enhancing factors (vef). Se trata de metaloproteasas que pueden llevar a cabo la degradación de las proteínas MLK (mucin like proteins) que se encuentran asociadas a las unidades de quitina de la membrana peritrófica. Se ha demostrado que la inserción y expresión de este tipo de genes en el genoma de nucleopoliedrovirus que no lo poseen naturalmente puede conducir a un aumento de la infectividad de AcMNPV en larvas susceptibles (Lepore et al., 1996). 


\section{Objetivos}

\section{Objetivo general}

Generar herramientas moleculares que permitan mejorar las propiedades bioinsecticidas y las estrategias de aplicación del baculovirus autóctono AgMNPV.

\section{Objetivos particulares}

- Desarrollo de un sistema de recombinación para la generación de AgMNPV recombinantes infectivos por vía oral que expresen genes heterólogos bajo el control de un promotor viral fuerte.

- Evaluación del sistema de recombinación a través de la generación de un virus AgMNPV recombinante infectivo por vía oral que expresa un gen indicador (reporter gene).

- Evaluación de la complementación funcional de la proteína mayoritaria del cuerpo de oclusión entre dos alfabaculovirus para la producción de baculovirus infectivos por vía oral no propagables en condiciones de campo.

- Generación de una línea celular indicadora inducible por infección con baculovirus para su aplicación en la manipulación de baculovirus en cultivo celular.

- Evaluación de la transactivación transcripcional de elementos regulatorios de diferentes etapas transcripcionales entre alfabaculovirus y betabaculovirus, con perspectivas a la generación de baculovirus híbridos con genes heterólogos expresados bajo el control de sus propios promotores. 


\section{Referencias:}

Abbas, M. y Boucias, D.G. (1984). Interaction between nuclear polyhedrosis virus-infected Anticarsia gemmatalis (Lepidoptera: Noctuidae) larvae and predator Podisus maculiventris (Say) (Hemiptera: Pentatomidae). Environ. Entomol. 13 (2), 599-602.

Adams, J.R. y McClintock, J.T. (1991). Chapter 6: Baculoviridae, Nuclear polyhedrosis viruses Part 1. Nuclear polyhedrosis viruses of insects. En "Atlas of Invertebrate Viruses" (J. R. Adams y J. R. Bonami, eds.), pp. 87-180. CRC Press, Boca Raton.

Afonso, C. L.; Tulman, E. R.; Lu, Z.; Balinsky, C. A.; Moser, B. A.; Becnel, J. J.; Rock, D. L.; Kutish, G. F. (2001). Genome sequence of a baculovirus pathogenic for Culex nigripalpus. J. Virol. 75, 11157-11165.

Allen, G.E.; Knell, J.D. (1977) A nuclear polyhedrosis virus of Anticarsia gemmatalis. I. Ultrastructure, replication, and pathogenicity. Fla. Entomol. 60, 233-240.

Aragón, J.; A. Molinari y S. Lorenzatti. (1998). Manejo integrado de plagas de soja. En: "El cultivo de soja en la Argentina". INTA. Editores: L. Giorda y H. Baigorri. pp. 247 -288.

Aragón, J. (2007). Sistema de alarma de plagas agrícolas con Trampa de Luz y observaciones de campo. En Planeta Soja. Editado por C. I. E. M. Juárez.

Berretta, M. y Romanowski, V. (2008). Baculovirus homologous regions ( $\mathrm{hrs}$ ): pleiotropic functional cis elements in viral genomes and insect and mammalian cells. Curr. Topics Virol. 7, 47-56.

Blissard, G.W. y Wenz, J.R. (1992). Baculovirus GP64 envelope glycoprotein is sufficient to mediate $\mathrm{pH}$ dependent membrane fusion. J. Virol. 66, 6829-6835.

Bonning, B.C. y Hammock, B.D. (1996) Development of recombinant baculoviruses for insect control. Ann. Rev. entomol. 41, 191-210.

Braunagel, S.C. y Summers, M. D. (1994). Autographa californica nuclear polyhedrosis virus, PDV, and ECV viral envelopes and nucleocapsids: structural proteins, antigens, lipid and fatty acid profiles. Virology. 202 (1), 315-328.

Bueno, R.C.O.F.; Parra, J.R.P.; Bueno, A.F.; Moscardi, F.; Oliveira, J.R.G.; Camillo, M.F. (2007). Sem barreira. 55, 12-15. (En Portugués).

Bulach, D.M.; Kumar, C.A.; Zaia, A.; Liang, B.; Tribe, D.E. (1999). Group II nucleopolyhedrovirus subgroups revealed by phylogenetic analysis of polyhedrin and DNA polymerase gene sequences. J. Invertebr. Pathol. 73 (1), 59-73.

Burden, J.P.; Hails, R.S.; Windass, J.D.; Suner, M.M.; Cory, J.S. (2000) Infectivity, speed of kill, and productivity of a baculovirus expressing the itch mite toxin txp-1 in second and fourth instar larvae of Trichoplusia ni. J. Invertebr. Pathol. 75, 226-236.

Carner, G.R.; Turnipseed, S.G. (1977). Potential of a nuclearpolyhedrosis virus for the control of the velvetbean caterpillar in soybean. J. Econ. Entomol. 70, 608-610.

Carstens, E. B.; Williams, G. V.; Faulkner, P.; Partington, S. (1992). Analysis of polyhedra morphology mutants of Autographa californica Nuclear polyhedrosis virus. Molecular and ultrastructural features. J. Gen. Virol. 73 (6), 1471- 1479.

Chisholm, G.E. y Henner, D.J. (1988). Multiple early transcripts and splicing of the Autographa californica nuclear polyhedrosis virus IE-1 gene. J. Virol. 62 (9), 3193-3200.

Corrêa-Ferreira, B.S.; Alexandre, T.M.; Pellizzaro, E.C.; Moscardi, F.; Bueno, A.F. (2010) Práticas de manejo de pragas utilizadas na soja e seu impacto sobre a cultura. Embrapa Soja, Londrina, PR, Circular Técnica. 78. (En Portugués).

Crouch, E.A. y Passarelli, A.L. (2002). Genetic requirements for homologous recombination in Autographa californica nucleopolyhedrovirus. J. Virol. 76, 9323-9334.

DePamphilis, M.L. (1993). Origins of DNA replication that function in eukaryotic cells. Curr. Opin. Cell Biol. 5, 434-441. 
Derksen, A.C.G. y Granados, R.R. (1988). Alteration of a Lepidopteran peritrophic membrane by baculoviruses and enhancement of viral infectivity. Virology 167, 242-250.

Engelhard, E.K.; Kam-Morgan, L.N.W.; Washburn, J.O.; Volkman, L.E. (1994). The insect tracheal system: A conduit for the systemic spread of Autographa californica M nuclear polyhedrosis virus. PNAS USA 91 (8), 3224-3227.

Engelhard, E.K. y Volkman, L.E. (1995). Developmental resistance in fourth instar Trichoplusia ni orally inoculated with Autographa californica M nuclear polyhedrosis virus. Virology 209 (2), 384-9.

Entwistle, P.F.; Evans, H.F. (1985). Viral Control. In Conprehensive Insect Fisiology. Biochemestry and farmacology; Gilbert, L.I.; Kerkut, G.A. eds. Oxford, Pergamon Press. 12, 347-412.

Ferrelli, M.L.; Salvador, R.; Biedma, M.E.; Berretta, M.F.; Haase, S.; Sciocco-Cap, A.; Ghiringhelli, P.D.; Romanowski, V. (2012). Genome of Epinotia aporema granulovirus (EpapGV), a polyorganotropic fast killing Betabaculovirus with a novel thymidylate kinase gene. BMC Genomics. 13:548. (+ suppl. mat.) DOI: 10.1186/1471-2164-13-548. [http://www.biomedcentral.com].

Fraser, M.J. (1986). Ultrastructural observations of virion maturation in Aulographa californica nuclear polyhedrosis virus infected Spodoptera frugiperda cell cultures. J. Ultrastruct. Mol. Struct. Res. 95, 189195.

Friesen, P.D. (1997). Regulation of baculovirus early gene expression. In The Baculoviruses, pp. 141-170. Edited by L. K. Miller. New York: Plenum.

Fukushima, D. (1991). Recent Progress of Soybean Proteins Foods: Chemistry, Technology, and Nutrition. Food Review International, 7:323-351.

Garcia-Maruniak, A.; Maruniak, J. E.; Zanotto, P. M.; Doumbouya, A. E.; Liu, J. C.; Merritt, T. M.; Lanoie, J. S. (2004). Sequence analysis of the genome of the Neodiprion sertifer nucleopolyhedrovirus. J. Virol. 78 (13), 7036-51.

Goldberg, A.; Romanowski, V.; Federici, B. and Sciocco-Cap, A. (2002). Effects of the EpapGV granulovirus on its host, Epinotia aporema. J. Invertebr. Pathol. 80 (3), 10-21.

Greenspan, G.L.; Corsaro, B.G.; Hughes, P.R.; Granados, R. R. (1991). In-vivo enhancement of baculovirus infection by the viral enhancing factor of a granulosis virus of the cabbage looper Trichoplusia ni (Lepidoptera: Noctuidae) . J. Invertebr. Pathol. 58 (2), 203-210.

Gross, C. y Rohrmann, G. F. (1993). Analysis of the role of 5' promoter elements and 3' flanking sequences on the expression of a baculovirus polyhedron envelope protein gene. Virology 192 (1), 273-281.

Gross, C.H.; Russell, R.L.Q.; Rohrmann, G.F. (1994). Orgyia pseudotsugata baculovirus p10 and polyhedron envelope protein genes: Analysis of their relative expression levels and role in polyhedron structure. J. Gen. Virol. 75 (5), 1115-1123.

Gutiérrez, B. \& Pulido, J. (1978). Ciclo de vida y hábitos de Anticarsia gemmatalis plaga de la Boya en el Valle del Cauca. Rev Colomb Entomol 4, 3-9.

Haas-Stapleton, E.J.; Washburn, J.O.; Volkman, L.E. (2004). P74 mediates specific binding of Autographa californica $\mathrm{M}$ nucleopolyhedrovirus occlusion-derived virus to primary cellular targets in the midgut epithelia of Heliothis virescens Larvae. J. Virol. 78, 6786-6791.

Haase, S.; Ferrelli, M.L.; Pidre, M.L.; Romanowski, V. (2013). Genetic Engineering of Baculoviruses, Current Issues in Molecular Virology - Viral Genetics and Biotechnological Applications, Prof. Victor Romanowski (Ed.), ISBN: 978-953-51-1207-5, InTech, Disponible online: http://www.intechopen.com/books/current-issues-in-molecular-virology-viral-genetics-andbiotechnological-applications/genetic-engineering-of-baculoviruses

Harrap, K.A. (1972). The structure of nuclear polyhedrosis viruses. Virology 50, 114-123.

Hashimoto, Y.; Corsaro, B.G.; Granados, R.R. (1991). Location and nucleotide sequence of the gene encoding the viral enhancing factor of the Trichoplusia ni granulosis virus. J. Gen. Virol. 72 (11), 26452652.

Hashimoto, Y.; Hayakawa, T.; Ueno, Y.; Fujita, T.; Sano, Y.; Matsumoto, T. (2000). Sequence analysis of the Plutella xylostella granulovirus genome. Virology 275, 358-372. 
Hawtin, R.E.; Zarkowska, T.; Arnold, K.; Thomas, C.J.; Gooday, G.W.; King, L.A.; Kuzio, J.A.; Possee, R.D. (1997). Liquefaction of Autographa californica nucleopolyhedrovirus-infected insects is dependent on the integrity of virus-encoded chitinase and cathepsin genes. Virology. 238 (2), 243-253.

Hayakawa, T.; Ko, R.; Okano, K.; Seong, S.-I.; Goto, C.; Maeda, S. (1999). Sequence analysis of the Xestia cnigrum granulovirus genome. Virology. 262, 277-297.

Hefferon, K.L.; Oomens, A.G.; Monsma, S.A.; Finnerty, C.M.; Blissard, G.W. (1999). Host cell receptor binding by baculovirus GP64 and kinetics of virion entry. Virology. 258 (2), 455-468.

Heldens, J.G.; Broer, R.; Zuidema, D.; Goldbach, R.W.; Vlak, J.M. (1997). Identification and functional analysis of a non-hr origin of DNA replication in the genome of Spodoptera exigua multicapsid nucleopolyhedrovirus. J. Gen. Virol. 78, 1497-1506.

Herniou, E.A.; Luque, T.; Chen, X.; Vlak, J.M.; Winstanley, D.; Cory, J.S.; O'Reilly, D. R. (2001). Use of whole genome sequence data to infer baculovirus phylogeny. J. Virol. 75 (17), 81117-81126.

Herniou, E. A.; Olszewski, J. A.; Cory, J. S.; O'Reilly, D. R. (2003). The genome sequence and evolution of baculoviruses. Ann. Rev. Entomol. 48, 211-234.

Herniou, E.A.; Arif, B.M.; Becnel, J.J.; Blissard G.W.; Bonning, B.; Harrison, R.; Jehle J.A.; Theilmann, D.A.; Vlak, J.M. (2011). Baculoviridae. In Virus taxonomy: classification and nomenclature of viruses: Ninth Report of the International Committee on Taxonomy of Viruses.; King, A.M.Q.; Adams, M.J.; Carstens, E.B.; Lefkowitz, E.J. eds. San Diego: Elsevier Academic Press. pp: 163-173.

Hinds, W.E. \& Osterberger, B.A. (1931). The soybean caterpillar in Louisiana. J. Econ. Entomol. 24, 11681173.

Hoopes, R.R., Jr. y Rohrmann, G.F. (1991). In vitro transcription of baculovirus immediate early genes: accurate mRNA initiation by nuclear extracts from both insect and human cells. PNAS USA. 88, 4513-4517.

Horton, H.M. y Burand, J.P. (1993). Saturable attachment sites for polyhedron-derived baculovirus on insect cells and evidence for entry via direct membrane fusion. J. Virol. 67 (4), 1860-1868.

Hotchkin, P.G. (1981). Comparison of Virion Proteins and Granulin From a Granulosis Virus Produced in Two Host Species. J. Invertebr. Pathol. 38 (2), 303-304.

Huang, J. y Levin, D.B. (1999). Identification and functional analysis of a putative non-hr origin of DNA replication from the Spodoptera littoralis type B multinucleocapsid nucleopolyhedrovirus. J. Gen. Virol. 80, 2263-2274.

lannone, N. (2007). ALERTA! Plagas de Soja. Editado por C. s. d. alerta: INTA Pergamino.

IJquel, W.F.; Westenberg, M.; Goldbach, R.W.; Blissard, G.W.; Vlak, J.M.; Zuidema, D. (2000). A novel baculovirus envelope fusion protein with a proprotein convertase cleavage site. Virology 275(1), 30-41.

Inceoglu, A.B.; Kamita, S.G.; Hinton, A.C.; Huang, Q.; Severson, T.F.; Kang, K.; Hammock, B.D. (2001) Recombinant baculoviruses for insect control. Pest manag. Sci. 57, 981-987.

Jehle, J.A., Blissard, G.W., Bonning, B.C., Cory, J.S., Herniou, E.A., Rohrmann, G.F., Theilmann, D.A., Thiem, S.M.; Vlak, J.M. (2006). On the classification and nomenclature of baculoviruses: a proposal for revision. Arch. Virol. 151, 1257-1266.

Keddie, B. A.; Aponte, G.W.; Volkman, L.E. (1989). The pathway of infection of Autographa californica nuclear polyhedrosis virus in an insect host. Science. 243 (4899), 1728-1730.

Kirkpatrick, B.A.; Washburn, J.O.; Engelhard, E.K.; Volkman, L.E. (1994). Primary infection of insect tracheae by Autographa californica M nuclear polyhedrosis virus. Virology 203 (1), 184-186.

Kogan, M. (1998). Integrated pest management: historical perspectives and contemporary developments. Annual Review of Entomology. 43:243-270

Kokubu, H. (1994) Entomología agrícola en Alto Paraná, Paraguay. I. Identificación de insectos, II. Dinámica poblacional de plagas de soja. Centro Tecnológico Agropecuario en Paraguay (CETAPAR-JICA). PGC-JR, 94-101.

Kool, M.; Ahrens, C.H.; Goldbach, R.W.; Rohrmann, G.F.; Vlak, J.M. (1994a). Identification of genes involved in DNA replication of the Autographa californica baculovirus. PNAS USA. 91, 11212-11216. 
Kool, M.; Goldbach, R.W.; Vlak, J.M. (1994b). A putative non-hr origin of DNA replication in the HindIII-K fragment of Autographa californica multiple nucleocapsid nuclear polyhedrosis virus. J. Gen. Virol. 75, 3345-3352.

Kool, M.; Ahrens, C.H.; Vlak, J.M.; Rohrmann, G. F. (1995). Replication of baculovirus DNA. J. Gen. Virol. 76, 2103-2118.

Lange, M. y Jehle, J.A. (2003). The genome of the Cryptophlebia leucotreta granulovirus. Virology 317 (2), 220-236.

Lanier, L.M. y Volkman, L.E. (1998). Actin binding and nucleation by Autographa california M nucleopolyhedrovirus. Virology. 243 (1), 167-177.

Larsson, R. (1984). Insect pathological investigations on Swedish Thysanura: A nuclear polyhedrosis virus of the bristletail Dilta hibernica. journal of Invertebrate Pathology 44(2), 177-172.

Lauzon, H. A.; Lucarotti, C. J.; Krell, P. J.; Feng, Q.; Retnakaran, A.; Arif, B. M. (2004). Sequence and organization of the Neodiprion lecontei nucleopolyhedrovirus genome. J. Virol. 78 (13), 7023-7035.

Lee, H. Y Krell, P.J. (1994). Reiterated DNA fragments in defective genomes of Autographa californica nuclear polyhedrosis virus are competent for AcMNPV-dependent DNA replication. Virology. 202, 418429.

Leisy, D.J. y Rohrmann, G.F. (1993). Characterization of the replication of plasmids containing $h r$ sequences in baculovirus-infected Spodoptera frugiperda cells. Virology. 196, 722-730.

Lepore, L.S.; Roelvink, P.R.; Granados, R.R. (1996). Enhancin, the granulosis virus protein that facilitates nucleopolyhedrovirus (NPV) infections, is a metalloprotease. J. Invertebr. Pathol. 68 (2), 131-140.

Lima, A.A.; Aragao, C.W.; de Castro, M.E.; Oliveira, J.V.; Sosa-Gómez, D.R.; Ribeiro, B.M. (2013). A Recombinant Anticarsia gemmatalis MNPV Harboring chiA and v-cath genes from Choristoneura fumiferana defective NPV induce host liquefaction and increased insecticidal activity PloS one 8:e74592 doi:10.1371/journal.pone.0074592

Lu, A. y Miller, L.K. (1995a). The roles of eighteen baculovirus late expression factor genes in transcription and DNA replication. J. Virol. 69, 975-982.

Lu, A. \& Miller, L. K. (1995b). Differential requirements for baculovirus late expression factor genes in two cell lines. J Virol 69, 6265-6272.

Lu, A. ; Seshagiri, S. ; Miller, L.K. (1996) Signal sequence and promoter effects on the efficacy of toxinexpressing baculoviruses as biopesticides. Biol. control 7, 320-332.

Lung, O.; Westenberg, M.; Vlak, J.M.; Zuidema, D.; Blissard, G.W. (2002). Pseudotyping Autographa californica multicapsid nucleopolyhedrovirus (AcMNPV): F proteins from group II NPVs are functionally analogous to AcMNPV GP64. J. Gen. Virol. 76, 5729-5736.

Luque, T.; Finch, R.; Crook, N.; O'Reilly, D.R.; Winstanley, D. (2001). The complete sequence of the Cydia pomonella granulovirus genome. J. Gen. Virol. 82, 2531-2547.

Martignoni, M. E.; Iwai, P. J. (1986). A catalog of viral diseases of insects, mites, and ticks. USDA Forest Service PNW-195. 4th ed., $51 \mathrm{p}$.

Mishra, S. (1998). Baculoviruses as biopesticides. Curr. Sci. 75, 1015-1022.

Moore, N.F.; King, L.A.; Possee, R.D. (1987). Viruses of insects. Ins. Sci. Appl. 3, 275-289.

Moscardi, F. (1989) Use of viruses for pest control in Brazil: the case of the nuclear polyhedrosis virus of the soybean caterpillar, Anticarsia gemmatalis. Memórias do Instituto Oswaldo Cruz. 84, 51-56.

Moscardi, F. (1999). Assessment of the application of baculoviruses for control of Lepidoptera. Annu Rev Entomol 44, 257-289.

Moscardi, F. A. (2007) Nucleopolyhedrovirus for control of the velvetbean caterpillar in Brazilian Soybeans. In Biological Control: A Global Perspective; Vincent, C.; Goethel, M.S., G. Lazarovits, G. eds. Oxfordshire, UK, and Cambridge, USA: CAB International. pp. 344-352.

Moscardi, F. M., L and Santos B. (2002). The successful use of AgMNPV for the control of velvetbean caterpillar, A. gemmatalis, in soybean in Brazil. In XXXV SIP Meeting, pp. 86-91. Foz do Iguazu, Brazil. 
Moscardi, F.; de Souza Lobo, M.; de Castro Batista, M.E.; Moscardi, L.M.; Szewczyk, B. (2011) Baculovirus Pesticides: Present State and Future Perspectives. In: Microbes and Microbial Technology; Ahmad, I.; Ahmad, F.; Pichtel, P. eds. Springer, New York. pp 415-445,

Murphy, F. A., Fauquet, C. M., Bishop, D. H. L., Ghabrial, S. A., Jarvis, A. W., Martelli, G. P., Mayo, M. P., and Summers, M. D. (1995). Classification and nomenclature of viruses: Sixth report of the international committee for the taxonomy of viruses. Archives of Virology, Supplement 10.

Nakasu, E.Y.; Williamson, S.M.; Edwards, M.G.; Fitches, E.C.; Gatehouse, J.A.; Wright, G.A.; Gatehouse, A.M. (2014) Novel biopesticide based on a spider venom peptide shows no adverse effects on honeybees. Proc. Biol. Sci. The Royal Society 281 doi:10.1098/rspb.2014.0619

Nomura, T. y Katunuma, N. (2005). Involvement of cathepsins in the invasion, metastasis and proliferation of cancer cells. J. Med. Invest. 52 (1-2), 1-9.

Ohba, M., y Tanada, Y. (1983). A synergistic factor enhances the in vitro infection of an insect baculovirus. Naturwissenschaften 70 (12), 613-614.

Ohkawa, T.; Majima, K.; Maeda, S. (1994). A cysteine protease encoded by the baculovirus Bombyx mori nuclear polyhedrosis virus. J. Virol. 68 (10), 6619-6625.

Oomens, A.G. y Blissard, G.W. (1999). Requirement for GP64 to drive efficient budding of Autographa californica multicapsid nucleopolyhedrovirus. Virology 254 (2), 297-314.

Oppenheimer, D.I. y Volkman, L.E. (1997). Evidence for rolling circle replication of Autographa californica M nucleopolyhedrovirus genomic DNA. Arch. Virol. 142, 2107-2113.

Panigatti, J.; Marelli, H.; Buschiazzo, D.; Gil, R. (1998). "Siembra Directa". Ed.: Hemisferio Sur. Buenos Aires. 333 pp.

Pearson, M.N.; Bjornson, R.M.; Ahrens, C.; Rohrmann, G.F. (1993). Identification and characterization of a putative origin of DNA replication in the genome of a baculovirus pathogenic for Orgyia pseudotsugata. Virology. 197, 715-725.

Pearson, M.N.; Groten, C.; Rohrmann, G.F. (2000). Identification of the Lymantria dispar nucleopolyhedrovirus envelope fusion protein provides evidence for a phylogenetic division of the Baculoviridae. J. Virol. 74 (13), 6126-6131.

Pearson, M.N. y Rohrmann, G.F. (1995). Lymantria dispar nuclear polyhedrosis virus homologous regions: characterization of their ability to function as replication origins. J. Virol. 69, 213-221.

Pearson, M.N.; Russell, R.L.; Rohrmann, G. F. (2001). Characterization of a baculovirus-encoded protein that is associated with infected-cell membranes and budded virions. Virology 291 (1), 22-31.

Pham, D.Q.; Hice, R.H.; Sivasubramanian, N.; Federici, B.A. (1993). The 1629-bp open reading frame of the Autographa californica multinucleocapsid nuclear polyhedrosis virus encodes a virion structural protein. Gene. 137 (2). 275-280.

Pullen, S.S. y Friesen, P.D. (1995). The CAGT motif functions as an initiator element during early transcription of the baculovirus transregulator ie-1. J. Virol. 69, 3575-3583.

Quant-Russell, R. L.P.; Pearson, M.N.; Rohrmann, G.F. Beaudreau, G.S. (1987). Characterization of baculovirus p10 synthesis using monoclonal antibodies. Virology. 160, 9-19.

Renkema, J.M.S. (2001). Formation, structure and rheological properties of soy protein gels. Ph. D. thesis, Wageningen University, The Netherlands

Robertson, J.S.; Harrap, K.A.; Longworth, J.F. (1974). Baculovirus morphogenesis: the acquisition of the virus envelope. J. Invertebr. Pathol. 23 (2), 248-51.

Rohrmann, G. (2013). Baculovirus Molecular Biology. Bethesda (MD): National Library of Medicine (US), National Center for Biotechnology Information. Disponible online: http://www.ncbi.nlm.nih.gov/books/NBK49500/

Romanowski, V. y Ghiringhelli, P. D. (2001). Biología molecular de baculovirus: Replicación y regulación de la expresión génica; en: Los Baculovirus y sus Aplicaciones como Bioinsecticidas, (P. Caballero, M. López-Ferber y T. Williams, editores); pp. 119-142; Phytoma - Universidad Pública de Navarra, Pamplona, España (ISBN: 84-932056-0-5) 
Russell, R.L. y Rohrmann, G.F. (1990). A baculovirus polyhedron envelope protein immunogold localization in infected cells and mature polyhedra. Virology 174 (1), 177-184.

Russell, R.L. y Rohrmann, G.F. (1997). Characterization of P91, a protein associated with virions of an Orgyia pseudotsugata baculovirus. Virology. 233 (1), 210-223.

Santos, B. (2003) Avanços na produção massal de lagartas de Anticarsia gemmatalis Hübner 1818 (Lepidoptera: Noctuidae) infectadas com o seu vírus de poliedrose nuclear, em laboratório e do bioinseticida à base desse vírus. PhD thesis, Universidade Federal do Paraná, Curitiba, Brazil. (En Portugués).

Saxena, H. (2008) Microbial Managment of Crop-Pest. J. Biopest., 1, 32-37.

Sciocco-Cap, A.; Parola, A.; Goldberg, A.; Ghiringhelli, D. \& Romanowski, V. (2001). Characterization of a granulovirus (EpapGV) isolated from Epinotia aporema (Lepidoptera: Tortricidae) larvae. Appl. Environ. Microbiol. 67, 3702-3706.

Shelton, A.M., Zhao, J.Z. \& Roush, R.T. (2002) Economic, ecological, food safety, and social consequences of the deployment of Bt transgenic plants. Annu. Rev. Entomol. 47, 845-881.

Slack, J.M.; Kuzio, J.; Faulkner, P. (1995). Characterization of v-cath, a cathepsin L-like proteinase expressed by the baculovirus Autographa californica Multiple Nuclear Polyhedrosis Virus. J. Gen. Virology 76, 1091-1098.

Slack, J.M.; Ribeiro, B.M.; Lobo de Souza, M. (2004). The gp64 locus of the Anticarsia gemmatalis Multicapsid Nucleopolyhedrovirus contains a three prime repair exonuclease homologue and lacks v-cath and ChiA genes. J. Gen. Virol. 85, 211-219.

Slavicek, J.M. y Popham, H.J. (2005). The Lymantria dispar nucleopolyhedrovirus enhancins are components of occlusion-derived virus. J. Virol. 79 (16), 10578-10588.

Smith, G.E.; Summers, M.D.; Fraser, M.J. (1983). Production of human beta interferon in insect cells infected with a baculovirus expression vector. Mol. Cell Biol. 3, 2156-2165.

Sosa-Gómez, D.R.; Moscardi, F.; Santos, B.; Alves, L.F.A.; Alves, S.B. (2008) Produçao e uso de vírus para o controle de pragas na América Latina. In: Controle Microbiano de Pragas na América Latina: abanicos e desafíos; Alves S. A.; R. B. Lopes eds. FEALQ, Piracicaba, Brazil. pp. 49-68. (En Portugués).

Szewczyk, B.; Rabalski, L.; Krol, E.; Sihler, W.; Souza, M.L. (2009). Baculovirus biopesticides - a safe alternative to chemical protection of plants. J. Biopestic. 2, 209-216.

Terra, W.R. y Ferreira, C. (1994). Insect digestive enzymes: properties, compartmentalization and function. Comp. Biochem. Phys. B. 109 B, 1-62.

Tinsley, T. W., and Kelly, D. C. (1985). Taxonomy and nonmenclature of insect pathogenic viruses. En "Insecticides for Biological Control" (K. Maramorosch and K. E. Sherman, eds.), Vol. 3. Academic Press, Orlando, FL.

Uwo, M.F.; Ui-Tei, K.; Park, P.; Takeda, M. (2002). Replacement of midgut epithelium in the greater wax moth, Galleria mellonela, during larval-pupal moult. Cell Tissue Res. 308 (2), 319-331.

Van der Wilk, F.; van Lent, J.W.M.; Vlak, J.M. (1987). Immunogold detection of polyhedrin, p10 and virion antigens in Autographa californica nuclear polyhedrosis virus-infected Spodoptera frugiperda cells. J. Gen. Virol. 68, 2615-2623.

van Oers, M.M.; Flipsen, J.T.; Reusken, C.B.; Sliwinsky, E.L.; Goldbach, R.W.; Vlak, J.M. (1993). Functional domains of the p10 protein of Autographa californica nuclear polyhedrosis virus. J. Gen. Virol. 74, 563574.

Vaaje-Kolstad, G.; Horn, S.J.; van Aalten, D.M.; Synstad, B.; Eijsink, V.G. (2005). The non-catalytic chitinbinding protein CBP21 from Serratia marcescens is essential for chitin degradation. J. biol. chem. 280, 28492-28497.

Vlak, J.M.; Schouten, A.; Usmany, M.; Belsham, G.J.; Klinge-Roode, E.C.; Maule, A.J.; Van Lent, J.W.; Zuidema, D. (1990). Expression of cauliflower mosaic virus gene I using a baculovirus vector based upon the 10 gene and a novel selection method. Virology 179, 312-320. 
Wang, P.; Hammer, D.A.; Granados, R.R. (1994). Interaction of Trichoplusia ni granulosis virus-encoded enhancin with the midgut epithelium and peritrophic membrane of four lepidopteran insects. J. Gen. Virol. 75 (8), 1961-1967.

Washburn, J.O.; Kirkpatrick, B.A.; Volkman, L.E. (1995). Comparative pathogenesis of Autographa californica M Nuclear Polyhedrosis Virus in larvae of Trichoplusia ni and Heliothis virescens. Virology. 209, 561-568.

Westenberg, M.; Wang, H.; IJkel, W.F; Goldbach, R.W.; Vlak, J.M.; Zuidema, D. (2002). Furin is involved in baculovirus envelope fusion protein activation. J. Virol. 76 (1), 178-184.

Westenberg, M.; Veenman, F.; Roode, E.C.; Vlak, J.M.; Zuidema, D. (2004). Functional analysis of the putative fusion domain of the baculovirus envelope fusion protein F. J. Virol. 78, 6946-6954.

Whitford, M.; Stewart, S.; Kuzio, J.; Faulkner, P. (1989). Identification and sequence analysis of a gene encoding gp67, an abundant envelope glycoprotein of the baculovirus Autographa californica nuclear polyhedrosis virus. J. Virol. 63 (3), 1393-1399.

Whitt, M. A., and Manning, J. S. (1988). A phosphorylated 34-kDa protein and a subpopulation of polyhedrin are tilo linked to the carbohydrate layer surrounding a baculovirus occlusion body. Virology. 163 (1), 33-42.

Williams, G.V.; Rohel, D.Z.; Kuzio, J.; Faulkner, P. (1989). A cytopathological investigation of Autographa californica nuclear polyhedrosis virus p10 gene function using insertion-deletion mutants. J. Gen. Virol. 70 (1), 187-202.

Williams, G.V. y Faulkner, P. (1997). Cytological Changes and Viral Morphogenesis during Baculovirus Infection. In The Baculoviruses. Ed. L. K. Miller. Plenum Press. New York, pp 61-108.

Wormleaton, S.; Kuzio, J.; Winstanley, D. (2003). The complete sequence of the Adoxophyes orana granulovirus genome. Virology. 311 (2), 350-365.

Wu, Y.; Lui, G.; Carstens, E. (1999). Replication, integration, and packaging of plasmid DNA cotransformation with baculovirus viral DNA. J. Virol. 73, 5473-5480.

Yamaguchi, N.; Chung, S.M.; Shiroeda, O.; Koyama, K.; Imanishi, J. (1990). Characterization of a cathepsin L-like enzyme secreted from human pancreatic cancer cell line HPC-YP. Cancer Res. 50 (3), 658-663.

Young, J.C.; Mackinnon, E.A.; Faulkner, P. (1993). The architecture of the virogenic stroma in isolated nuclei of Spodoptera frugiperda cells in vitro infected by Autographa californica nuclear polyhedrosis virus. J. Struct. Biol. 110 (2), 141-153.

Zanotto, P. M.; Kessing, B. D.; Maruniak, J. E. (1993). Phylogenetic interrelationships among baculoviruses: evolutionary rates and host associations. J. Invertebr. Pathol. 62 (2), 147-164. 



\section{Capítulo 2}

Desarrollo de un sistema de recombinación para la obtención de AgMNPV modificados 



\subsection{Introducción}

Diversos miembros de la familia Baculoviridae son utilizados como agentes de control biológico con excelentes resultados; sin embargo, la aplicabilidad de algunas especies en el manejo de plagas agrícolas se ha visto limitada por su lenta velocidad de acción y estrecho rango de hospedador (Inceoglu et al., 2001; Moscardi, 1999; Szewczyk et al., 2006). Las estrategias más exploradas hasta el momento consisten en la interferencia de la fisiología de la larva hospedante (O'Reilly y Miller, 1991), la introducción de toxinas específicas de insecto (Bonning y Hammock, 1996; Inceoglu et al., 2001; Mishra, 1998) y la expresión de genes que colaboran con la degradación de la membrana peritrófica (MP) de la larva (Lima et al., 2013). Entre estas estrategias, la que ha conseguido resultados más destacados es la inserción de genes que codifican proteínas tóxicas específicas para insectos e inocuas para vertebrados (Haase et al., 2013; Hawtin et al., 2006; Romanowski, 2002).

La mayoría de los sistemas utilizados para la modificación genética de los baculovirus se basan en la recombinación homóloga entre un baculovirus parental y un vector de transferencia. En los primeros sistemas desarrollados, se interrumpía un gen no esencial por doble recombinación y se aislaba el virus recombinante por sucesivos plaqueos. En muchos casos el gen seleccionado para la interrupción era el de la poliedrina, ya que no es esencial para la transmisión del virus en cultivos celulares y su deleción ocasiona un fenotipo fácilmente visible. Sin embargo, los virus deficientes en poliedrina no producen poliedros y no por esta razón no se pueden utilizar como insecticidas.

Posteriormente, se desarrollaron sistemas más sofisticados que permitieron aumentar la proporción de virus recombinante mediante la reducción de la población parental y a su vez conservar en el recombinante el gen de poliedrina. Esto permitió el desarrollo de muchos baculovirus con propiedades insecticidas mejoradas.

Una de las estrategias más exitosas que ha sido aplicada consiste en la incorporación de sitios de restricción únicos en el genoma parental (Kitts et al., 1990). Para la generación de virus recombinantes, el genoma parental se digiere con la enzima de restricción adecuada. El genoma linealizado no resulta infectivo y puede recuperar su circularidad e infectividad a través de la doble recombinación con el vector de transferencia. La 
introducción de sitios de restricción duplicados puede mejorar aún más la proporción de progenie recombinante (Kitts y Possee, 1993).

Anteriormente, en nuestro grupo de investigación se desarrolló un AgMNPV linealizable a través de la introducción de dos sitios de restricción para la enzima I-Ppol, una endonucleasa de restricción codificada en un intrón (homing endonuclease) (McCarthy, 2005).

La introducción de los dos sitios de restricción en el genoma de este virus recombinante se logró mediante el reemplazo génico por doble recombinación homóloga, intercambiando el marco de lectura del gen de la poliedrina por el de la $\beta$-galactosidasa de E. coli. La digestión con la enzima I-Ppol, que fue puesta a punto en nuestro laboratorio anteriormente (McCarthy y Romanowski, 2006), permite la linealización del genoma y la liberación del marco de lectura del gen de la enzima $\beta$-galactosidasa de $E$. coli, facilitando la diferenciación de virus digerido (lacZ-) del virus parental (lacZ+ ${ }^{+}$.

En el presente capítulo se describe el desarrollo de vectores de transferencia y la puesta a punto de la obtención de recombinantes utilizando este virus como parental.

\subsection{Materiales y métodos}

\subsubsection{Células y virus}

Las células High Five ${ }^{\mathrm{TM}}$, (BTI-TN-5B1-4, derivadas de Trichoplusia nu) fueron mantenidas a $27^{\circ} \mathrm{C}$ en medio de Grace (Invitrogen ${ }^{\mathrm{TM}}$ ) suplementado con $10 \%$ de suero fetal bovino (Bioser) y $50 \mu \mathrm{g} / \mathrm{ml}$ de gentamicina (Parafarm). El virus AgMNPV-I-Ppol (McCarthy, 2005) fue propagado en monocapa de células High Five ${ }^{T M}$, y cuantificado mediante ensayo de placas siguiendo el protocolo estándar (O'Reilly et al., 1994).

\subsubsection{Purificacion de DNA viral a pequena escala}

Los BV se aislaron a partir del sobrenadante del cultivo de células infectadas. El sobrenadante se clarificó por centrifugación a $1000 \times \mathrm{g}$ a $4^{\circ} \mathrm{C}$ durante $5 \mathrm{~min}$. La precipitación de los viriones se realizó centrifugando $1,5 \mathrm{ml}$ de este sobrenadante a $14000 \times \mathrm{g} \mathrm{y} 4^{\circ} \mathrm{C}$ durante $45 \mathrm{~min}$ en un tubo eppendorf. Luego se descartó el sobrenadante. Este procedimiento se repitió tres veces en el mismo tubo. El pellet de 
viriones se resuspendió delicadamente en buffer de lisis (Tris- $\mathrm{HCl}(\mathrm{pH} \mathrm{7,6)} 10 \mathrm{mM}$; EDTA $10 \mathrm{mM}$; SDS 0,25\%), se agregó proteinasa $\mathrm{K}(500 \mu \mathrm{g} / \mathrm{ml})$ y se incubo a $60^{\circ} \mathrm{C}$ durante un mínimo de $2 \mathrm{~h}$. Se realizaron tres extracciones sucesivas (fenol/ fenolcloroformo-isoamílico/ cloroformo-isoamílico) agregando $500 \mu \mathrm{l}$ de solvente orgánico en cada caso. Se llevó la fase acuosa a una concentración final de $\mathrm{NaCl} 0,2 \mathrm{M}$, se agregó $500 \mu \mathrm{l}$ de isopropanol para precipitar y posteriormente se lavó el pellet con $500 \mu \mathrm{l}$ de etanol $70 \%$, se centrifugó a $14000 \times \mathrm{g}$ a $4^{\circ} \mathrm{C}$ por $30 \mathrm{~min}$. El pellet se resuspendió en $20 \mu \mathrm{l}$ de agua bidestilada estéril.

\subsubsection{Generación del vector de transferencia pl3}

El vector de transferencia pl3 fue construido mediante ligación secuencial de fragmentos del genoma del aislamiento (wild type) AgMNPV-2D (Zanotto et al., 1992) y algunos fragmentos de plásmidos comerciales (Figura 2.1). Las secuencias de los primers utilizados se detallan en la tabla 2.1. Los detalles de las reacciones de PCR se pueden encontrar en el Anexo (sección A.3). En primera instancia, se generó un fragmento que incluye las secuencias de los promotores de los genes $p 10$ y polh en disposición opuesta. Para esto, se amplificó el promotor del gen p10 con los primers Upr10-Ndel y Lpr10-Sgf10 y se clonó en el vector pGEM-T Easy, generando el vector pGEM-T-pp10. Por otro lado, el promotor del gen de poliedrina se amplificó con los primers Uprom-Ndel y pPolhrev-Notl. Tanto el producto de PCR del promotor de poliedrina como el vector pGEM-T-pp10 se digirieron con Ndel y Pstl y se ligaron, generando el plásmido denominado pGET-T-pp10-ppolh.

La región upstream del gen de poliedrina fue amplificada por PCR y fusionada por Splice Overlap Extension (SOE) PCR a la región de poliadenilación de SV40 del plásmido comercial pDsRED1-N1. El producto de fusión fue ligado en los sitios Rsrll y Notl del plásmido comercial pIRES (Clontech), generando de esta forma el plásmido pIRES-UpspA. Los primers utilizados para amplificar la región upstream fueron Uup-Rsrll y Lup-Sfi y la región polyA de SV40 fue amplificada del vector comercial pDsRED1-N1 con los primers Lred-Sfi y SV40/CcdB-Xmal. 


\begin{tabular}{|c|c|}
\hline Primer & Secuencia $\left(5^{\prime}-3^{\prime}\right)$ \\
\hline Upr10-Ndel & GCCCATATGCACAGTCAACGCCGGCC \\
\hline Lpr10-Sgf10 & GCCCGCGATCGCGACGATATTGAAATGGTTGAAATAAATATAC \\
\hline Uprom-Ndel & GCCCCATATGAAGTTGCAGCTCAAGCAGGATTGT \\
\hline pPolhrev-Notl & CATTGCGGCCGCGAATTCAAGCTTAGTTATAGCAAATTTTACTAC \\
\hline Uup-Rsr & CCCCGGTCCGATGACCGAATTGAGCAACGCG \\
\hline Lup-Sfi & CTAGTT GGCCGCCTCGGCCTGCTGACTAAGCGTAGACC \\
\hline Lred-Sfi & CGCTTAGTGGCCGAGGCGGCCAACTAGAATGCAGTGAAAAAAATG \\
\hline SV40/CcdB-Xmal & ATGGACCACCCCGGGTTCCTGTAGCGGCCGCG \\
\hline Polhi-Sgfl & AAATTTGCGATCGCTATGCCAGATTATACG \\
\hline Ldw-BglII & GGAAAGATCTATACACACGTTAGGCGAGCGCCG \\
\hline
\end{tabular}

Tabla 1.1: Primers utilizados en la construcción del vector de transferencia pl3. En negrita se destaca los nucleótidos que hibridan con el molde. Subrayados en itálica se destacan las secuencias de reconocimiento para las enzimas de restricción agregadas con el primer.

El fragmento con el promotor de $p 10$ y el promotor de poliedrina en disposición opuesta fue liberado del vector pGEM-T-p10-ppolh por digestión con Notl y fue ligado en el sitio Notl del vector pIRES-UpspA, dando lugar al vector pIRES-UpspApp10-ppolh. Finalmente, el ORF del gen de la poliedrina fue amplificó con los primers Polhi-Sgfl y Ldw-Bglll y se ligó al vector pIRES-UpspA-pp10-ppolh con los sitios $S g f l$ and $B g / l l$, dando como resultado el vector de transferencia pl3.

\subsubsection{Clonado de genes en el vector de transferencia pl3}

Con el fin de evaluar la funcionalidad del vector de transferencia generado se le insertó el gen que codifica la proteína fluorescente verde EGFP (Enhanced Green Fluorescent Protein). El ORF de EGFP fue obtenido mediante PCR utilizando como molde el plásmido peGFP-N3 (Clontech) y los primers eGFP/Up-EcoRI y eGFP/ Down-Xhol. Los detalles del ciclado y las secuencias de los primers se encuentran en el Anexo (sección A.3). El producto de PCR fue purificado de gel y clonado en el vector pGEM-T Easy (Promega). Luego, el inserto fue liberado del vector por digestión con EcoRI y clonado en el vector pl3, para generar el vector pl3-GFP. 


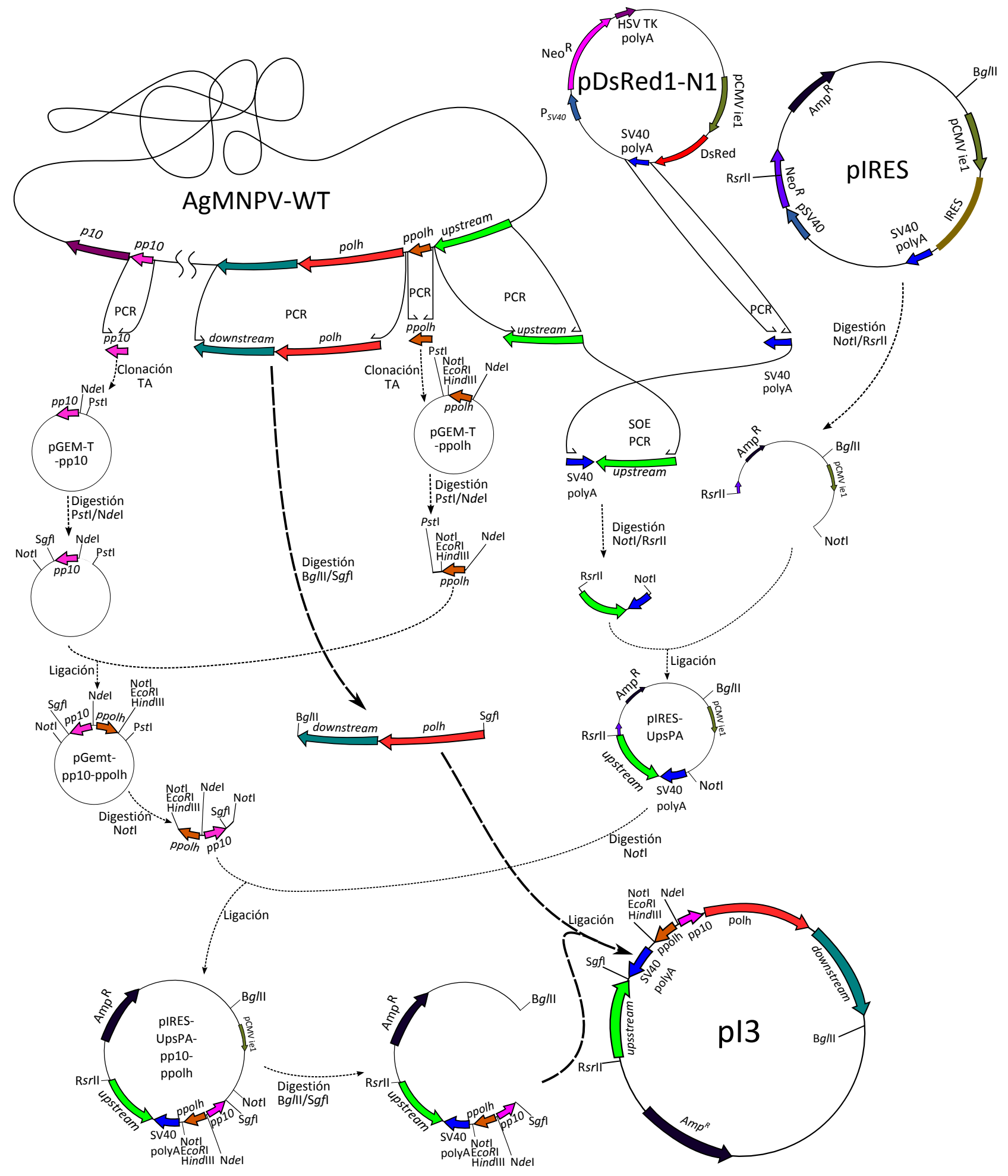

Figura 2.1: Representación esquemática de la construcción del vector pl3 
Se ha construido una serie de clones de pl3-X con distintos genes de interés. Los genes fueron amplificados mediante PCR utilizando como molde DNA viral de EpapGV (y primers específicos detallados en el Anexo (sección A.3)). Los productos de PCR fueron aislados de gel clonados en pGEM-T Easy (Promega). Los productos de digestión de EpapGV se liberaron de pGEM-T Easy con EcoRI fueron clonados en pl3, previamente digerido con la misma enzima. En el caso del gen tox34 de Pyemotes tritici, se liberó el ORF del plásmido pBS-Tox34 (Arana, 2003) con EcoRI y se clonó en pl3. Posteriormente se incorporó a este útimo vector el promotor de egt de AgMNPV para producir una variante donde el gen tox34 se encuentra bajo el control de este promotor. Los plásmidos obtenidos fueron: pl3-gp37, y pl3-chiA, pl3-tox34, pl3-pegtAg-tox43 y pl3-5kb.

\subsubsection{Digestión del DNA viral con la enzima I-Ppol}

Para la reacción de digestión del DNA viral AgMNPV-I-Ppol, se siguió el protocolo propuesto por McCarthy (2006), en el cual se utiliza buffer E (Promega) en lugar del buffer recomendado por el fabricante. Las condiciones de incubación y cantidad de enzima que se usaron fueron las recomendadas por el proveedor.

\subsubsection{Obtencion de virus recombinantes}

Se sembraron $10^{6}$ células High Five ${ }^{\mathrm{TM}}$ en placas de $35 \mathrm{~mm}$ y se incubaron por una noche a $27^{\circ} \mathrm{C}$ para favorecer su adhesión a la superficie. Las células fueron cotransfectadas con una mezcla de 500 ng de DNA genómico de AgMNPV-I-Ppol linealizado y 1 $\mu \mathrm{g}$ del plásmido de transferencia correspondiente. Se utilizó el reactivo de transfección Cellfectin II (Invitrogen ${ }^{\mathrm{TM}}$ ), siguiendo el protocolo del fabricante con algunas modificaciones. Brevemente, el DNA viral y el plásmidico fueron diluidos en $200 \mu \mathrm{l}$ de medio de Grace libre de suero (solución A), $4 \mu \mathrm{l}$ del reactivo de transfección fueron diluidos en $200 \mu \mathrm{l}$ de Grace's libre de suero (solución B). La solución B fue agregada gota a gota a la solución A y esta mezcla incubada a temperatura ambiente por 45 minutos. Pasado este tiempo se agregaron $400 \mu \mathrm{l}$ de medio de Grace libre de suero. La mezcla final fue agregada a la monocapa celular, previamente lavada dos veces con PBS $1 \mathrm{X}$, e incubada por una noche a $27^{\circ} \mathrm{C}$. Luego de este tiempo, se agregaron $2 \mathrm{ml}$ de medio de Grace suplementado con 10\% de suero. Luego de seis días, se recolectó el 
medio sobrenadante, que contenía la progenie viral. Los virus recombinantes fueron purificados mediante ensayos de placa sucesivos (O'Reilly et al., 1994). La detección de los virus recombinantes fue monitoreada por la formación de placas blancas y la aparición de poliedros luego del agregado de $500 \mu \mathrm{g} / \mathrm{ml}$ de X-gal por placa. Los virus recombinantes potenciales fueron monitoreados mediante PCR, siguiendo las consideraciones descriptas (McCarthy y Romanowski, 2008).

\subsection{Caracterización del virus AgMNPV-GFP}

El virus AgMNPV-GFP se amplificó en células High Five ${ }^{\mathrm{TM}}$ y las células infectadas se observaron por microscopía de fluorescencia (Nikon Eclipse Ti). Se purificó DNA genómico de AgMNPV-GFP y del virus parental AgMNPV-I-Ppol de acuerdo a los protocolos establecidos (Murhammer, 2008) y se desarrollaron varios ensayos de PCR para confirmar la estructura genética del virus recombinante (Figura 2.6).

\subsection{Infección oral de larvas de $A$. gemmatalis con AgMNPV-GFP}

Se infectaron células High Five ${ }^{\mathrm{TM}}$ con los virus AgMNPV-2D (wild type) y AgMNPV. Se lisaron las células mediante el agregado de SDS a concentración final de 0,2\% y se agitó con vórtex. Luego se centrifugó 2 min a 50 x g para eliminar todos los restos celulares. El sobrenadante se centrifugó por 20 min a 2000 x g, este paso se repitió 3 veces. El pellet obtenido se disolvió en $1 \mathrm{ml}$ de agua bidestilada y se centrifugó nuevamente 2000 x g. Este paso se repitió 3 veces para asegurar la eliminación de restos de detergente. Finalmente los $O B$ se resuspendieron en $50 \mu$ de agua y se verificó la calidad de la extracción por medio de observación al microscopio de contraste de fase (400 X). La concentración de poliedros fue determinada mediante contabilización con una cámara de Neubauer.

Para la infección oral de larvas de $A$. gemmatalis, se recurrió al método de la alimentación por gotas. Las suspensiones de poliedros se prepararon en agua destilada con Coomasie blue al $1 \%(p / v)$ y sacarosa al $1 \%(p / v)$.

Para evaluar la expresión del gen heterólogo (GFP) in vivo se utilizaron larvas de $A$. gemmatalis en tercer estadio y se administraron 500 OB/larva (aproximadamente 20 veces la dosis letal media $\left(\mathrm{LD}_{50}\right)$ (Biedma, 2009) ajustando la concentración de las 
suspensiones de poliedros al volumen medio ingerido por estas larvas en el estadio mencionado (Kunimi y Fuxa, 1996). Se comparó la fluorescencia de larvas infectadas con AgMNPV-GFP y AgMNPV-2D por exposición de los organismos enteros a luz UV (Figura 2.) Luego de cinco días de infección, las larvas fueron disecadas, separando el tejido intestinal y la hemolinfa. Estas extracciones fueron observadas al microscopio.

Para evaluar los parámetros insecticidas del virus recombinante, se administraron a través de suspensiones en gotas dosis de $50 \mathrm{OB}$ (aproximadamente el valor de $L_{50}$ ) y 300 OB (aproximadamente 6 veces la LD50) (Biedma, 2009) considerando el volumen medio ingerido por larvas de A. gemmatalis en tercer estadio (Kunimi y Fuxa, 1996), utilizando grupos de 20 larvas para cada dosis y cada virus (AgMNPV-wt y AgMNPV-GFP). Como control negativo se utilizó un grupo de 20 larvas que se alimentó con una suspensión sin OB. Se registró la mortalidad de las larvas por día.

\subsection{Resultados}

\subsubsection{Construcción del plásmido de transferencia pl3}

Se construyó un plásmido de transferencia que contiene regiones para la recombinación homóloga con el virus parental linealizable AgMNPV. El genoma parental linealizable no contiene el gen de la poliedrina. Por esta razón, el vector de transferencia pl3 posee el marco de lectura de la poliedrina bajo el control del promotor del gen p10. De esta

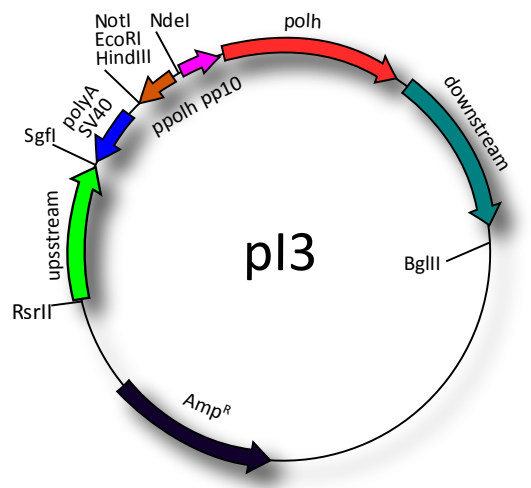
forma, la doble recombinación homóloga permite la recuperación de la infectividad del virus y la recuperación de la capacidad de generar cuerpos de oclusión, lo cual constituye una ventaja porque permite diferenciar visualmente las células infectadas con virus recombinantes de las células infectadas con virus parental.

Figura 2.2. Esquema del vector de transferencia desarrollado para la modificación genética de AgMNPV. El sitio de clonado que secuencias de reconocimiento para Notl, EcoRI y HindIII permite la clonación de marcos de lectura para la expresión heteróloga de proteínas bajo el control del promotor de poliedrina. Las regiones upstream y downstream corresponden a las secuencias adyacentes al ORF de poliedrina y permiten la recombinación con el virus parental AgMNPV-I-Ppol. 


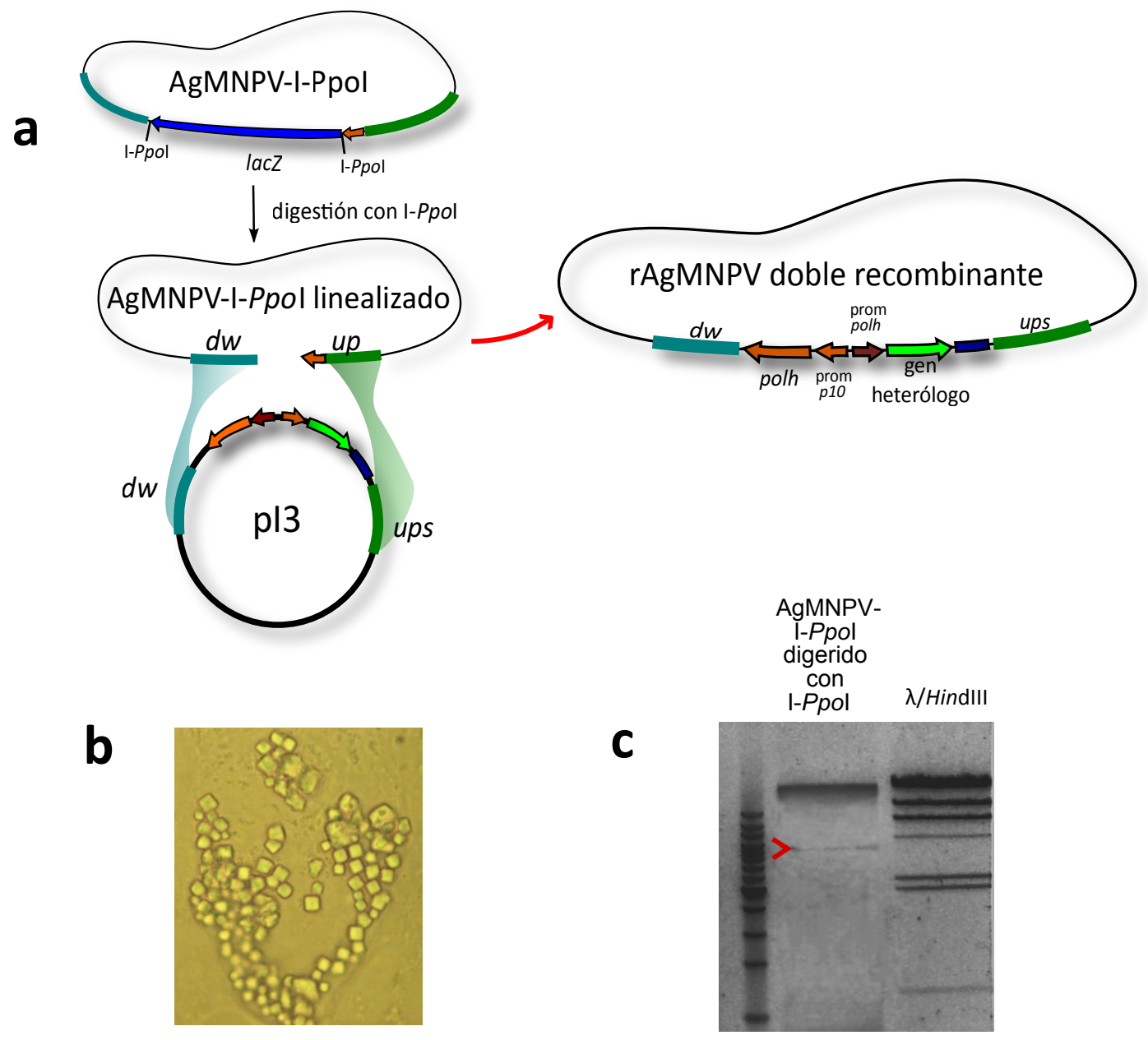

Figura 2.3: a) Representación esquemática del sistema de generación de AgMNPV recombinantes (rAgMNPV) desarrollado. b) Microscopía óptica de poliedros recombinantes purificados. c) Digestión de AgMNPV-I-Ppol con I-Ppol. Se observa la liberación del fragmento del ORF de lacZ.

El objetivo del vector de transferencia generado es la expresión de genes heterólogos incorporados en el genoma de AgMNPV. Para esto se dispuso en el plásmido un sitio de clonado que permite la inserción de marcos de lectura para la expresión bajo el control del promotor de poliedrina.

\subsubsection{Generación del virus recombinante AgMNPV-GFP}

Para validar el sistema desarrollado se procedió a generar un baculovirus AgMNPV recombinante que exprese la proteína verde fluorescente (GFP). En la primera etapa, se clonó el marco de lectura de la proteína GFP en el vector pl3, generando el plásmido pl3-GFP. 
Luego se cotransfectaron células High Five ${ }^{\mathrm{TM}}$ con el genoma parental AgMNPV-I-Ppol digerido con I-Ppol y el vector pl3-GFP. 5 días después de la transfección, cuando se evidenció la aparición de cuerpos de oclusión y la expresión de GFP en algunas células, se recolectó el sobrenadante del cultivo celular (que contiene virus brotantes). El sobrenadante recolectado se utilizó para infectar nuevas monocapas de células High Five ${ }^{T M}$ y luego de la infección se inmovilizaron las células con agarosa para aislar placas de clones del virus recombinante. El proceso de plaqueo se repitió

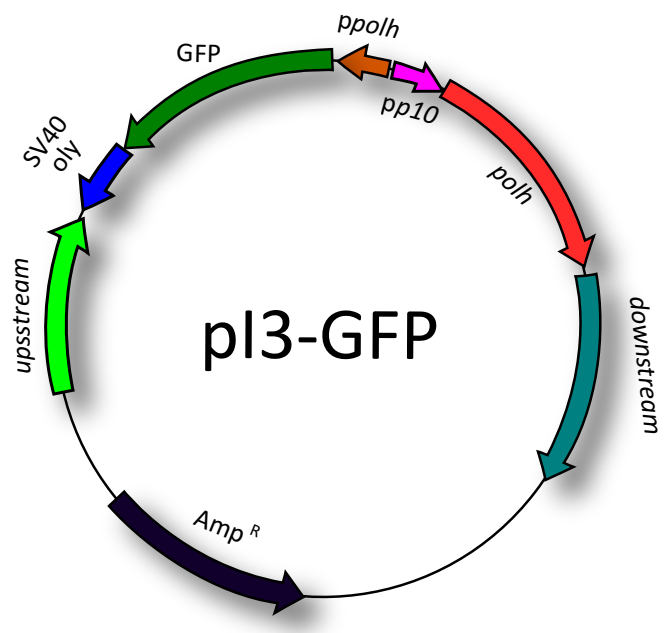

Figura 2.4: Plásmido de transferencia pl3-GFP. tres veces.

\subsubsection{Caracterización genética del virus AgMNPV-GFP clonado}

Los clones de AgMNPV se diferenciaron por PCR, descartando aquellos recombinantes que resultaron de recombinación homóloga simple o ilegítima y seleccionando un clon que resultó de una doble recombinación homóloga para continuar el estudio. Para esto, se diseñó una serie de ensayos de PCR en los cuales un primer hibrida contra una región que está en el genoma del virus parental, por fuera del locus de recombinación y el otro primer hibrida con una región propia del plásmido de transferencia. De esta forma, la PCR sólo se verifica en caso de que haya ocurrido recombinación homóloga entre el virus parental y el vector. Como control negativo de recombinación se utilizó una PCR que amplifica un fragmento del ORF de $\beta$-galactosidasa (presente en el genoma parental no digerido) y como control positivo del molde se utilizó una PCR que amplifica el promotor del gen ie-1 de AgMNPV.

\subsubsection{Determinación de la infectividad de AgMNPV-GFP en larvas por vía oral y parámetros insecticidas.}

Se purificaron cuerpos de oclusión de AgMNPV-GFP a partir del cultivo celular infectado y se evaluó su infectividad oral sobre larvas de $A$. gemmatalis. 
Se observó la expresión del gen recombinante en las larvas infectadas y en los tejidos hemolinfáticos y traqueolares analizados (Figura 2.7). Además, se determinaron los parámetros bioinsecticidas del virus recombinante, demostrando que tanto la dosis letal media $\left(\mathrm{LD}_{50}\right)$ como el tiempo letal medio $\left(\mathrm{LT}_{50}\right)$ resultaron comparables con los del aislamiento de virus salvaje AgMNPV-2D (Figura 2.8). No se observó mortalidad de larvas en el grupo de control no infectado.
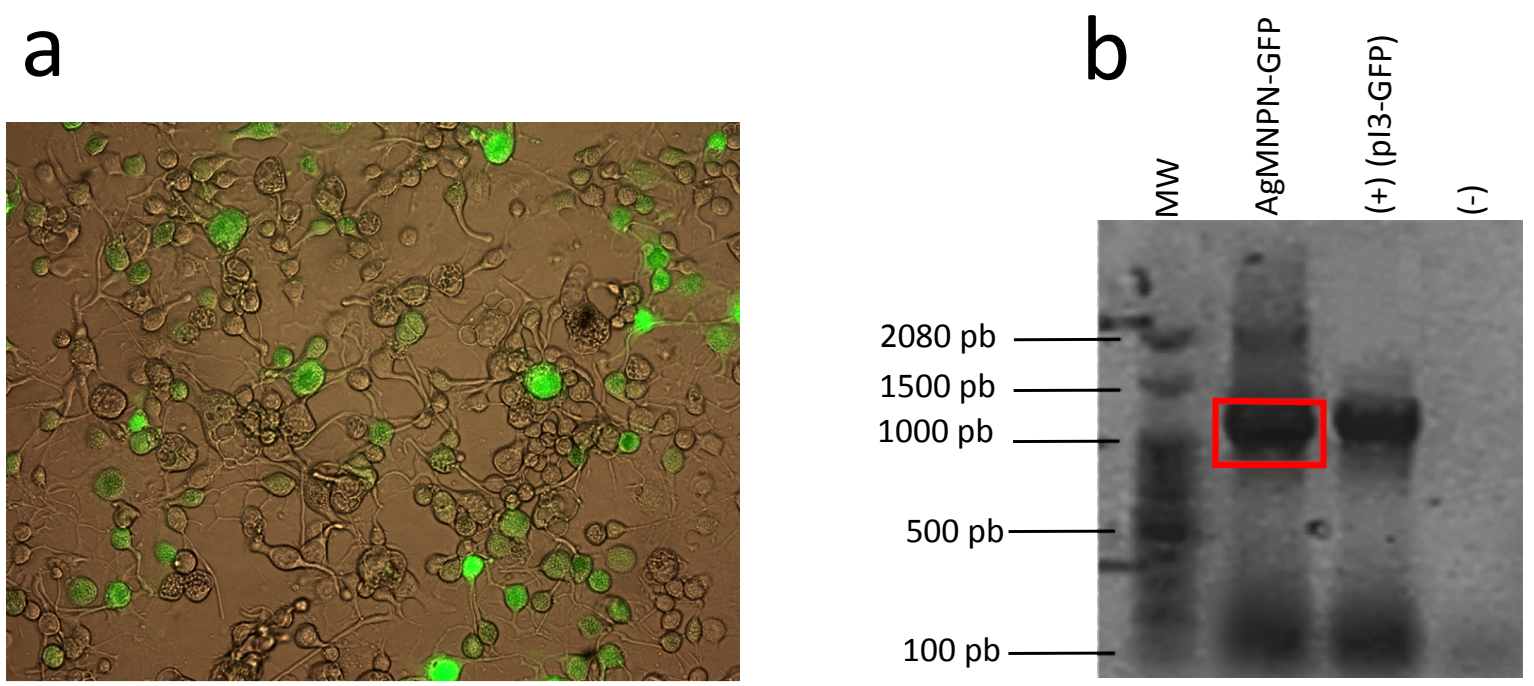

Figura 2.5: a) Miscroscopía de fluorescencia de células High Five ${ }^{\mathrm{TM}}$ cotransfectadas con AgMNPV-I-Ppol linealizado y pI3-GFP. b) Detección del gen heterólogo en sobrenadante de células cotransfectadas por PCR.

\subsubsection{Clonación de genes de interés en el vector pl3}

Se clonaron genes con el objeto de poder generar AgMNPV recombinantes con propiedades insecticidas mejoradas en el vector de transferencia pl3. Los genes seleccionados fueron: El gen que codifica la toxina TxP-I de P. tritici (gen tox34), bajo el control del promotor de poliedrina del vector pl3 y el promotor de egt de AgMNPV; los genes gp37, y chiA (quitinasa) de EpapGV, bajo el control del promotor de poliedrina del vector pl3 y un fragmento de $5 \mathrm{kpb}$ que contiene los genes gp37, v-cath (catepsina) y chiA de EpapGV bajo los promotores de cada gen de EpapGV (Figura 2.9). Este último vector permitiría la construcción de un AgMNPV recombinante que exprese estos 
tres genes, que presumiblemente actúan de forma coordinada para la degradación de la membrana peritrófica del intestino del insecto.

a
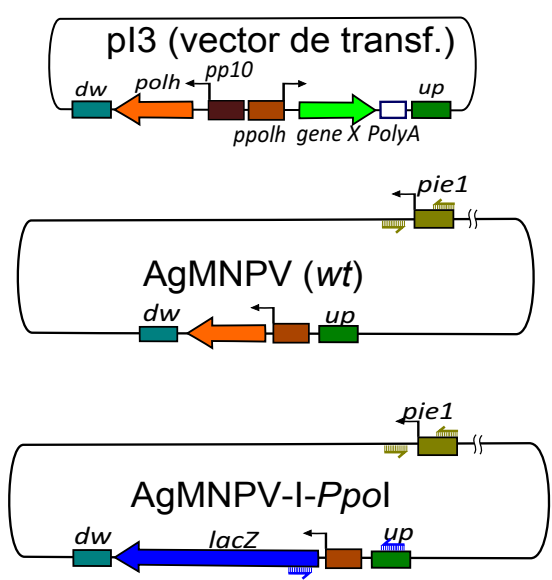
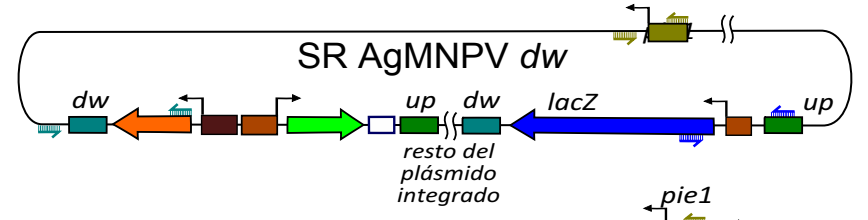

SR AgMNPV up

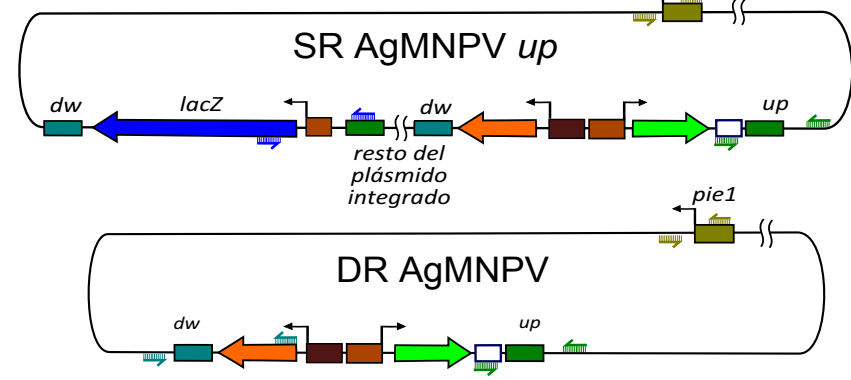

b

\begin{tabular}{|c|c|c|c|c|c|}
\hline PCR & $\begin{array}{c}\text { AgMNPV } \\
\text { (wf) }\end{array}$ & $\begin{array}{c}\text { AgMNPV } \\
\text { I-Ppol }\end{array}$ & $\begin{array}{c}\text { SR } \\
\text { AgMNPV } \\
\text { up }\end{array}$ & $\begin{array}{c}\text { SR } \\
\text { AgMNPV } \\
\text { dw }\end{array}$ & $\begin{array}{c}\text { DR } \\
\text { AgMNPV }\end{array}$ \\
\hline pie1 & 438 & 438 & 438 & 438 & 438 \\
\hline lacZ & - & 735 & 735 & 735 & - \\
\hline$d w$ & - & - & - & 1382 & 1382 \\
\hline up & - & - & 1346 & - & 1346 \\
\hline
\end{tabular}

C

\begin{tabular}{|c|c|c|c|c|c|c|c|c|}
\hline & \multicolumn{4}{|c|}{ AgMNPV-I-Ppol } & \multicolumn{4}{|c|}{ AgMNPV-GFP } \\
\hline 3 & 立. & $\overline{\mathrm{N}}$ & है & 당 & 竞. & $\overline{\bar{N}}$ & है & $\frac{5}{\delta}$ \\
\hline
\end{tabular}

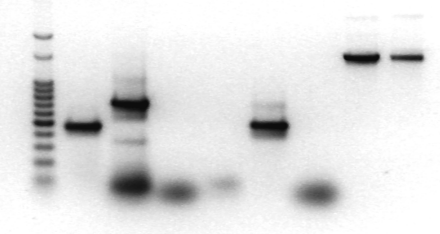

d

\begin{tabular}{|l|l|l|}
\hline PCR & Primer & Secuencia $\left(5^{\prime}\right.$ - $^{\prime}$ ') \\
\hline Downstream $(d w)$ & polhi-Sgfl & AAATTTGCGATCGCTATGCCAGATTATACG \\
\hline & AgDwrec & AACCCGTAAAGCCGCCGTTG \\
\hline Upstream $($ up $)$ & AgUpsrec & GGCGCGAGTTAAATAGTCTG \\
\hline & SV40/CcdB-Xmal & ATGGACCACCCCGGGTTCCTGTAGCGGCCGCG \\
\hline LacZ & LacZ & TGGATCTGCAACATGTCCCAGGTGA \\
\hline & ppolhAg600UpHind III & TGTACAAAGCTTCTAATTGCGTAAAAATG \\
\hline pie-1 & pie1Agfw & TATAAGATCTCAGGGTACAATTG \\
\hline & pie1Agrev & CATGAAGATCTATTTATACC \\
\hline & & \\
\hline
\end{tabular}

Figura 2.6: Caracterización genética del virus recombinante AgMNPV-GFP. a) Se destacan los posibles productos de PCR que se amplificarían en cada virus recombinante que es posible obtener o en el virus parental. b) Tamaño del amplicón que se espera para cada reacción de PCR en cada especie recombinante o en el virus parental. Los guiones indican que para ese virus no se espera producto de PCR. c) Resultado de las reacciones de PCR obtenido con el virus doble recombinante AgMNPV-GFP y comparación con el virus parental AgMNPV-I-Ppol. d) Tabla con los detalles primers utilizados en cada reacción de PCR de la caracterización. 

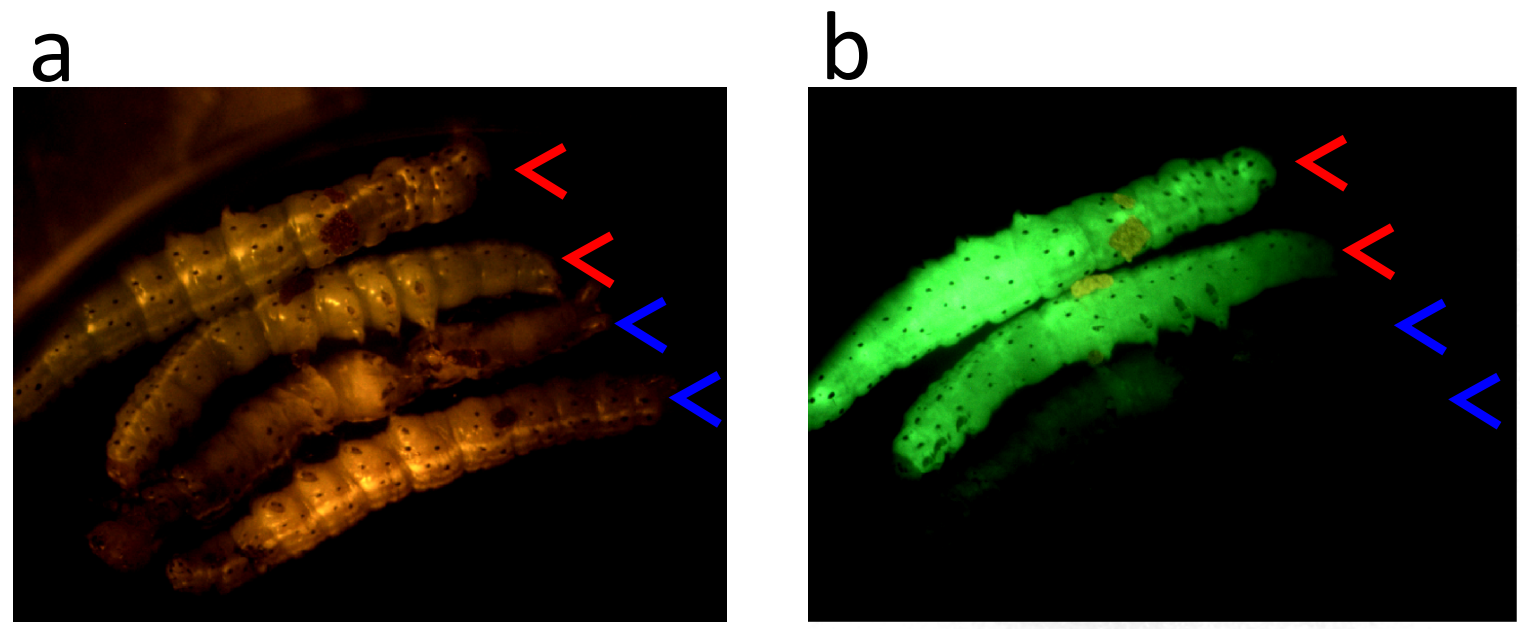

C

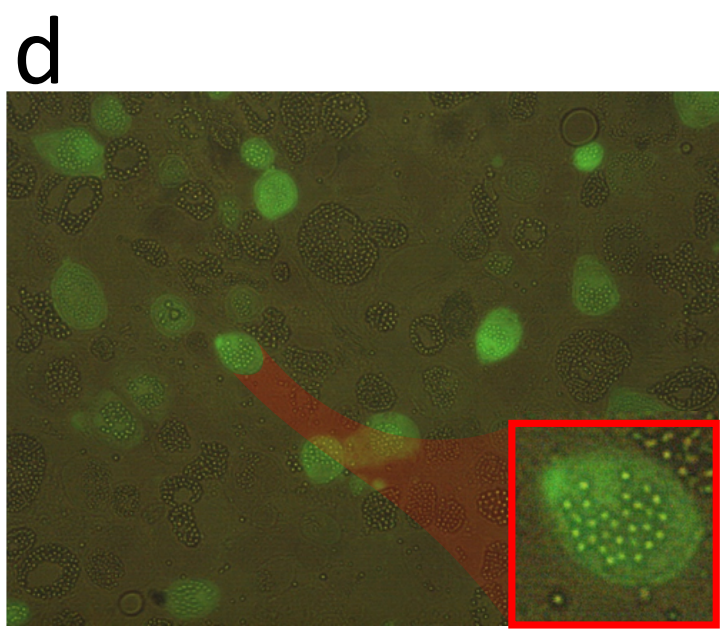

Figura 2.7: Expresión de GFP en larvas de A. gemmatalis infectadas con AgMNPV-GFP. a,b) Larvas de $A$. gemmatalis infectadas con AgMNPV-GFP (puntas de flecha rojas) y AgMNPV-wt (puntas de flecha azules), expuestas a luz visible (a) y UV (b). c,d) Tejido traqueolar c) y hemolinfático d) de larvas de $A$. gemmatalis infectadas con AgMNPV-GFP, observadas al microscopio de fluorescencia con filtro para GFP.

\section{Tiempo letal medio}

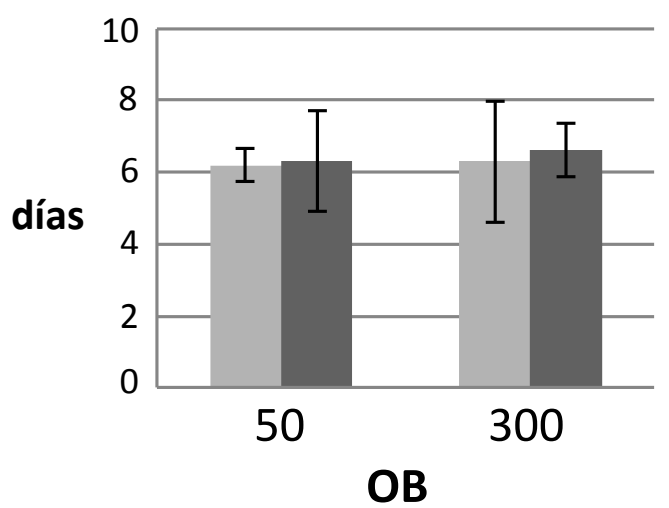

\section{Mortalidad}

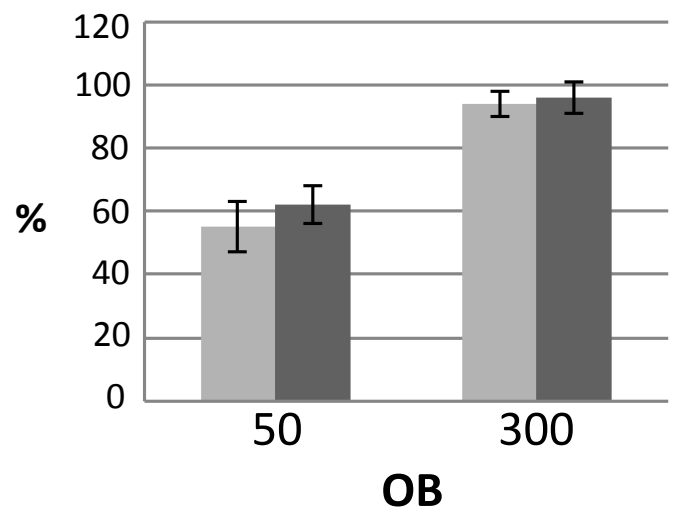

Figura 2.8: Resultados de los bioensayos comparativos entre el virus recombinante AgMNPV-eGFP y el virus parental AgMNPV-wt. 

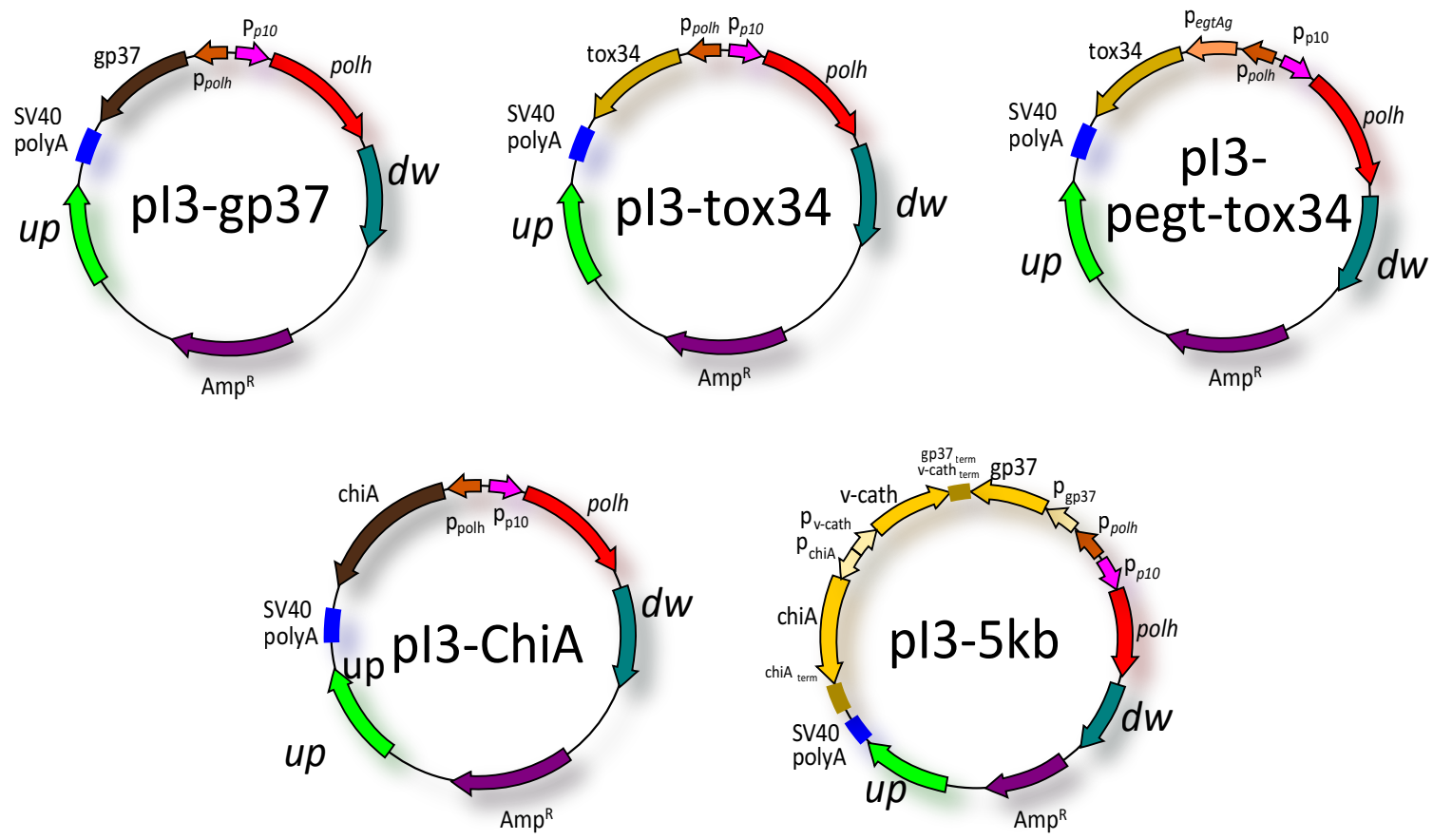

Figura 2.9. Vectores de transferencia desarrollados en base a pl3.

\subsection{Discusión}

Al momento, se ha desarrollado un número limitado de AgMNPV recombinantes (Arana et al., 2001; Lima et al., 2013; Pinedo et al., 2003; Ribeiro et al., 2001). Recientemente, se desarrolló un baculovirus que incluye el gen de poliedrina $\left(p o l h^{+}\right)$y expresa los genes de catepsina ( $v$-cath) y quitinasa (chiA) de CfDefNPV (Lima et al., 2013). AgMNPV no posee estos genes (Oliveira et al., 2006), por lo cual su adición contribuyó a aumentar la capacidad insecticida del virus. Sin embargo, sin la disposición de un sistema de recombinación eficiente, el aislamiento del virus genéticamente modificado resultó muy laboriosa, requiriendo siete aislamientos sucesivos por placa. Además, a pesar de que la expresión de los genes heterólogos de este virus recombinante fue verificada, los detalles de la estructura genética no son claros.

Considerando que toma cerca de 10 días completar una ronda de purificación por plaqueo, la generación de un virus recombinante sin un sistema eficiente podría tomar más de tres meses. Se ha demostrado que el pasaje repetido de virus en 
cultivo celular puede conducir a la acumulación de virus defectivos que se pueden convertir en la especie predominante (Pijlman, et al., 2001). Además, el pasaje de virus en cultivo celular puede favorecer la acumulación de mutaciones en los genes determinantes de la infectividad oral, ya que estos no están sujetos a presión de selección en cultivo in vitro.

En resumen, aquí se desarrolló un sistema de recombinación que permitió el aislamiento de un virus AgMNPV que expresa un gen heterólogo bajo el control de un promotor viral fuerte. Se comprobó que este baculovirus recombinante generado poseen infectividad oral sobre larvas de $A$. gemmatalis y que la expresión del gen heterólogo en las larvas es muy elevada. El virus recombinante posee una actividad biológica semejante al virus parental sobre larvas de A. gemmatalis. El desarrollo descripto es el primer paso para la construcción de AgMNPV que expresen genes destinados a mejorar las propiedades insecticidas del virus. 


\section{Referencias}

Arana, E. I. (2003). Desarrollo de vectores para la construcción de recombinantes del virus de la poliedrosis nuclear de Anticarsia gemmatalis (oruga de las leguminosas). Tesis doctoral, Universidad Nacional de La Plata.

Arana, E.I.; Albarino, C.G.; O'Reilly, D.; Ghiringhelli, P.D.; Romanowski, V. (2001). Generation of a recombinant Anticarsia gemmatalis multicapsid nucleopolyhedrovirus expressing a foreign gene under the control of a very late promoter. Virus Genes, 22 (3), 363-372.

Biedma, M.E. (2009). "Desarrollo de un sistema de recombinación para su aplicación al estudio de determinantes genéticos que afectan la infectividad de baculovirus de interés agronómico". Tesis doctoral, Universidad Nacional de La Plata.

Bonning, B. C. y Hammock, B. D. (1996). Development of recombinant baculoviruses for insect control. Annu. Rev. Entomol., 41, 191-210.

Haase, S.; Ferrelli, M.L.; Pidre, M.L.; Romanowski, V. (2013). Genetic Engineering of Baculoviruses, Current Issues in Molecular Virology - Viral Genetics and Biotechnological Applications, Prof. Victor Romanowski (Ed.) ISBN: 978-953-51-1207-5, InTech, DOI: 10.5772/56976.

Hawtin, R.E.; King, L.A.; Possee, R.D. (2006). Prospects for the development of a genetically engineered baculovirus insecticide. Pest. Sci., 34, 9-15.

Inceoglu, A.B.; Kamita, S.G.; Hinton, A.C.; Huang, Q.; Severson, T.F.; Kang, K.; Hammock, B.D. (2001). Recombinant baculoviruses for insect control. Pest. Manag. Sci., 57 (10), 981-987.

Kitts, P.A.: Ayres, M.D.: Possee, R.D. (1990). Linearization of baculovirus DNA enhances the recovery of recombinant virus expression vectors. Nucleic Acids Res., 18 (19), 5667-5672.

Kitts, P.A. y Possee, R.D. (1993). A method for producing recombinant baculovirus expression vectors at high frequency. Biotechniques, 14 (5), 810-817.

Kunimi, Y.; Fuxa, J.R. (1996) Volumes ingested by four species of noctuids with reference to peroral droplet bioassay of baculoviruses. J. Invertebr. Pathol., 68, 310-311.

Lima, A.A.; Aragao, C.W.; de Castro, M.E.; Oliveira, J.V.; Sosa Gomez, D.R.; Ribeiro, B.M. (2013). A Recombinant Anticarsia gemmatalis MNPV Harboring chiA and v-cath genes from Choristoneura fumiferana defective NPV induce host liquefaction and increased insecticidal activity. PLoS One, 8(9), e74592. doi: 10.1371/journal.pone.0074592

McCarthy, C.B. (2005). Generación de recombinantes del virus dee la poliedrosis nuclear de Anticarsia gemmatalis (AgMNPV). Tesis doctoral, Universidad Nacional de La Plata.

McCarthy, C.B. y Romanowski, V. (2006). Digestion of I-Ppol recognition sites in unfavorable sequence contexts achieved by changing the reaction conditions. Biochem. Genet., 44 (1-2), 61-68.

McCarthy, C. B. y Romanowski, V. (2008). A simplified method for the extraction of baculoviral DNA for PCR analysis: a practical application. J. Virol. Methods, 148 (1-2), 286-290.

Mishra, S. (1998). Baculoviruses as biopesticides. Curr. Sci., 75(1015-1022).

Moscardi, F. (1999). Assessment of the application of baculoviruses for control of Lepidoptera. Annu. Rev. Entomol., 44, 257-289.

Murhammer, D.W. (2008). Baculovirus and Insect Cell Expression Protocols. Methods in Molecular Biology, 388.

O'Reilly, D.R.; Miller, L.K.; Luckow, V.A. (1994). Baculovirus Expression Vectors: A Laboratory Manual. Oxford University Press. 347 pages.

O’Reilly, D. R. y Miller, L. K. (1991). Improvement of a baculovirus pesticide by deletion of the egt gene. Nat. Biotech., 9, 1086-1089.

Oliveira, J.V.; Wolff, J.L.; Garcia-Maruniak, A.; Ribeiro, B.M.; de Castro, M.E.; de Souza, M.L.; Moscardi, F.; Maruniak, J.E.; Zanotto, P.M. (2006). Genome of the most widely used viral biopesticide: Anticarsia gemmatalis multiple nucleopolyhedrovirus. J. Gen. Virol., 87 (Pt 11), 3233-3250. 
Pijlman, G.P.; van den Born, E.; Martens, D.E.; Vlak, J.M. (2001). Autographa californica baculoviruses with large genomic deletions are rapidly generated in infected insect cells. Virology, 283 (1), 132-138.

Pinedo, F.J.R.; Moscardi, F.; Luque, T.; Olszewski, J.A.; Ribeiro, B.M. (2003). Inactivation of the ecdysteroid UDP-glucosyltransferase (egt) gene of Anticarsia gemmatalis nucleopolyhedrovirus (AgMNPV) improves its virulence towards its insect host. Biol. Control, 27, 336-344.

Ribeiro, B.M.; Gatti, C.D.; Costa, M.H.; Moscardi, F.; Maruniak, J.E.; Possee, R.D.; Zanotto, P.M. (2001). Construction of a recombinant Anticarsia gemmatalis nucleopolyhedrovirus (AgMNPV-2D) harbouring the beta-galactosidase gene. Arch. Virol., 146 (7), 1355-1367.

Romanowski, V. (2002). Engineered baculovirus insecticides. Proceedings of the VIII International Colloquium on Insect Pathology and Microbial Control \& 35th Annual Meeting of the Society for Invertebrate Pathology, Foz do Iguaçu, Brasil, 19-27.

Szewczyk, B.; Hoyos-Carvajal, L.; Paluszek, M.; Skrzecz, I.; Lobo de Souza, M. (2006). Baculoviruses--reemerging biopesticides. Biotechnol. Adv., 24 (2), 143-160.

Zanotto, P.M.; Sampaio, M.J.; Johnson, D.W.; Rocha, T.L.; Maruniak, J.E. (1992). The Anticarsia gemmatalis nuclear polyhedrosis virus polyhedrin gene region: sequence analysis, gene product and structural comparisons. J. Gen. Virol., 73, 1049-1056. 



\section{Capítulo 3}

Estudio de la complementación funcional del gen de poliedrina entre dos alfabaculovirus 



\subsection{Introducción}

Los ensayos de complementación genética efectuados en baculovirus han permitido determinar que algunos genes esenciales no pueden ser reemplazados por sus homólogos de virus relacionados, aportando indicios sobre la importancia de estos genes en la interacción específica virus-hospedador (Yu y Carstens, 2012; González et al., 1989). Entre los genes de baculovirus cuya complementación entre especies ha sido estudiada se encuentra la poliedrina, que es la proteína mayoritaria de los cuerpos de oclusión de los poliedrovirus. En el primer estudio publicado se reemplazó el gen de la poliedrina de SfMNPV (virus de la poliedrosis nuclear múltiple de Spodoptera frugiperda) en AcMNPV (González et al., 1989). A partir de una biblioteca genómica de SfMNPV, se detectó un clon con un inserto de 3.7 kb, que incluía el gen completo de la poliedrina de SfMNPV con secuencias flanqueantes. Se reemplazó de esta forma el locus de poliedrina de AcMNPV por el correspondiente de SfMNPV. Sin embargo, los resultados de estos experimentos no fueron claros: debido a la indeterminación del genoma recombinante, es probable que la construcción obtenida contuviera regiones del gen de la poliedrina de AcMNPV, lo que condujo a la generación productos de transcripción interrumpidos.

En otro ensayo, con el objetivo de analizar la complementación funcional entre los genes de poliedrina y granulina, el gen de la poliedrina del virus de la poliedrosis nuclear de Bombix mori (BmNPV) fue reemplazado en BmNPV por el gen de la granulina del virus de la granulosis de Trichoplusia ni (TnGV). Al infectar células derivadas de B. mori con el BmNPV recombinante que posee la granulina de TnGV aparecieron poliedros grandes y de forma cúbica, parecidos a los cuerpos de oclusión (OB) tanto en el núcleo como en el citoplasma (Zhou, et al., 1998). Estas estructuras no contenían nucleocápsides en su interior, demostrando la incapacidad de la granulina para complementar la poliedrina en estas especies. Considerando que el ciclo de replicación de los granulovirus involucra la ruptura de la membrana nuclear, se especuló que la limitante en la formación de cuerpos de oclusión heterólogos se debía a la ausencia de una señal de localización nuclear en la granulina. Sin embargo, en otro trabajo se demostró que la granulina de TnGV con una secuencia de localización nuclear agregada no puede complementar la ausencia de poliedrina de AcMNPV (Eason et al., 1998), 
y que el baculovirus recombinante da lugar a grandes inclusiones cúbicas en el citoplasma y núcleo de las células infectadas. Estas estructuras cristalinas carecen de bordes biselados característicos de los poliedros de AcMNPV wild type, que contienen fracturas y pocos o ningún virión ocluido.

Posteriormente, se investigó acerca de la posibilidad de complementar genes de baculovirus a través de la generación de cultivos celulares transgénicos (López, et al., 2010). Se transfectaron cultivos de la línea Sf9 (derivadas del lepidóptero Spodoptera frugiperda) con un plásmido que contenía el gen de la poliedrina de AcMNPV y se obtuvieron cultivos celulares transgénicos por selección con blasticidina. Al infectar con un ACMNPV recombinante deficiente en poliedrina, se detectó la expresión de poliedrina y, además, se observaron estructuras cristalinas, como poliedros, mediante microscopia óptica. Finalmente, se demostró la infectividad oral de estos poliedros por la detección de fluorescencia en larvas Rachiplusia nu (susceptibles a AcMNPV) infectadas con un poliedros de un AcMNPV recombinante en el que el gen de polh había sido reemplazado por el gen de la proteína fluorescente verde $\left(g f p^{+}-p o l h^{-}\right)$, ocluido en el cultivo transgénico.

Los ensayos de complementación concentrados en el gen que codifica la proteína mayoritaria de los cuerpos de oclusión de los nucleopoliedrovirus, no han logrado aún establecer con claridad si un gen de poliedrina heterólogo puede restituir completamente el fenotipo wild type de un virus deficiente en este gen. No obstante, se sabe que la formación de poliedros no depende únicamente de la secuencia de aminoácidos, sino que también se encuentran involucrados los fenómenos de interacción entre la poliedrina y los virones.

El objetivo del trabajo descripto en este capítulo consiste en estudiar la complementación funcional de la poliedrina. Para esto, se desarrollaron dos líneas celulares derivadas de High Five ${ }^{\mathrm{TM}}$ (Maruniak, et al., 1994; Wickham, et al., 1992). Una de ellas contiene en su genoma una construcción compuesta por el marco de lectura de la poliedrina de ACMNPV bajo el control del promotor de la poliedrina de AcMNPV. La otra línea celular contiene en su genoma una construcción compuesta por el marco de lectura de la poliedrina de AgMNPV bajo el control del mismo promotor de poliedrina 
de AcMNPV. En ambas líneas, para proveer un nivel de expresión mayor, se adicionó al plásmido la región $h r 1$ de AcMNPV. Se ha establecido que esta región con secuencias repetidas tiene la capacidad de incrementar drásticamente los niveles de transcripción de los genes que se encuentren en su cercanía (Guarino, et al., 1986).

El promotor de poliedrina utilizado en la construcción de las dos líneas transgénicas, derivado de AcMNPV, requiere la presencia de factores de transcripción virales para su activación. Por lo tanto, se espera que la poliedrina heteróloga se exprese cuando la línea celular se infecte con AcMNPV o con otro baculovirus heterólogo, dependiendo en este último caso de la transactivación heteróloga del promotor (Figura 3.1).

Así, se espera que la infección de la línea celular que expresa la poliedrina de AgMNPV con un AcMNPV defectivo en poliedrina $\left(p o / h^{-}\right)$active al promotor de poliedrina de AcMNPV integrado en el genoma de la célula y la aparición de poliedros indicaría que la poliedrina de AgMNPV puede sustituir funcionalmente a su homóloga en AcMNPV. De la misma forma, al infectar la línea celular que expresa la poliedrina de AcMNPV con AgMNPV defectivo en poliedrina, la formación de poliedros indicaría que la poliedrina de AcMNPV puede sustituir las funciones de su homóloga de AgMNPV. En este último caso, además, para que ocurra la complementación funcional mencionada, los factores transcripcionales de AgMNPV deben reconocer al promotor de AcMNPV que controla la expresión del gen.

Además de la relevancia del estudio de la complementación de la poliedrina, las líneas celulares que se obtuvieron pueden ser de gran utilidad para el empaquetamiento de virus recombinantes deficientes en poliedrina con potencial como bioinsecticidas. Los virus empaquetados en cultivo celular poseen infectividad por vía oral pero tienen una propagación limitada, debido a su incapacidad de producir poliedros en las larvas infectadas. Experimentos anteriores llevados a cabo con poliedros de AcMNPV con viriones deficientes en el gen de poliedrina generados por co-oclusión en cultivo celular demostraron que la persistencia en el ambiente de estas especies deficientes es muy bajo (Wood, et al., 1994). Esto los convierte en excelentes candidatos para bioensayos controlados a campo y para el desarrollo de bioinsecticidas genéticamente modificados. 
Finalmente, se generaron cultivos celulares transgénicos que expresan genes de poliedrina de AgMNPV y AcMNPV y GFP bajo el control de los elementos regulatorios de AgMNPV, con el objetivo de que los elementos regulatorios autólogos incrementen los niveles de expresión de poliedrina al infectar con AgMNPV.

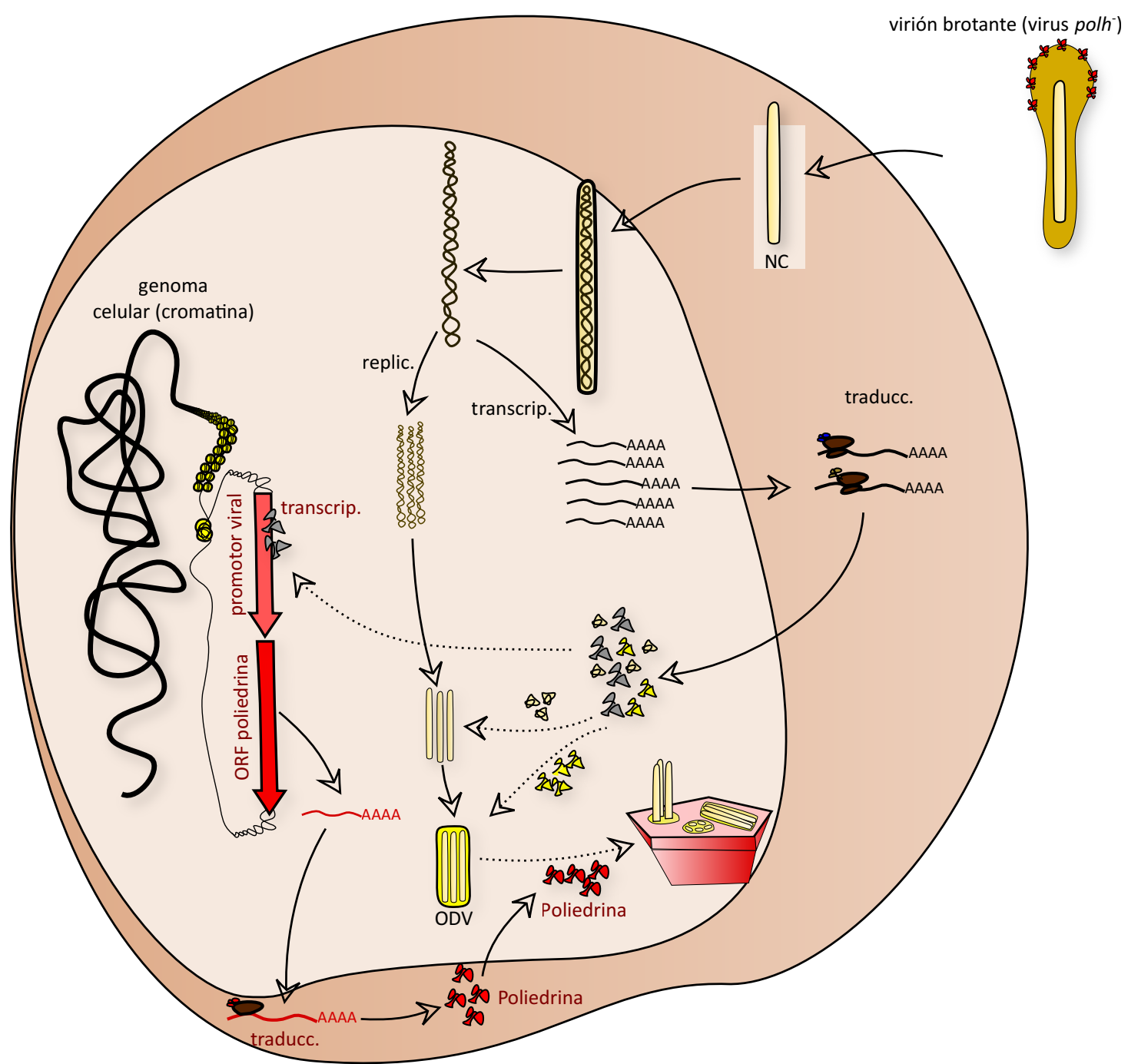

Figura 3.1: Esquema del concepto de complementación utilizando líneas celulares que transgénicas que expresan poliedrina, donde se representa una célula transgénica infectada por un virión brotante. Al infectar con un virus delecionado en el gen de poliedrina $\left(p o / h^{-}\right)$, los factores transcripcionales codificados por el virus (proteínas en gris) reconocen el promotor viral en un cromosoma de la célula hospedadora. Así se activa la transcripción de la poliedrina, que es luego traducida y al ingresar al núcleo, donde se forman los ODV, los incluye formando cuerpos de oclusión. Si el virus deficiente pertenece a una especie (código amarillo) y el gen de poliedrina a otra especie (código rojo), se formarán OB híbridos. Esta posibilidad permite analizar la complementación funcional del gen de poliedrina entre varias especies. 


\subsection{Materiales y Métodos}

\subsubsection{Amplificación y clonado de la región codificante del gen de la poliedrina de AgMNPV}

Los vectores pXXL-GFP y pXXL-PolhAcMNPV fueron gentilmente cedidos por los Dres. Gabriela López y Oscar Taboga (Instituto de Biotecnología, CICVyA, Instituto Nacional de Tecnología Agropecuaria (IB-INTA)) (Figura 3.2). Para la generación del vector pXXLPolhAgMNPV, se amplificó por PCR el marco de lectura abierto (ORF) de la poliedrina de AgMNPV (polhAgMNPV) utilizando los primers polhi-Sgfl (Forward) y polh-back (Reverse) y el genoma de AgMNPV-2D (aislamiento wild type) como molde. El producto de PCR se clonó en el vector comercial pGEM-T Easy y se subclonó en el vector pXXLPolhAcMNPV. Este vector contiene el promotor de polh de AcMNPV (hr1/ppolhAcMNPV), seguido por el ORF de la poliedrina de AcMNPV. El gen de la poliedrina está flanqueado en ambos lados por sitios de restricción para la enzima Notl. El vector se digirió con Notl para la liberación del ORF de la poliedrina de AcMNPV y se insertó el ORF de la poliedrina de AgMNPV en su lugar.
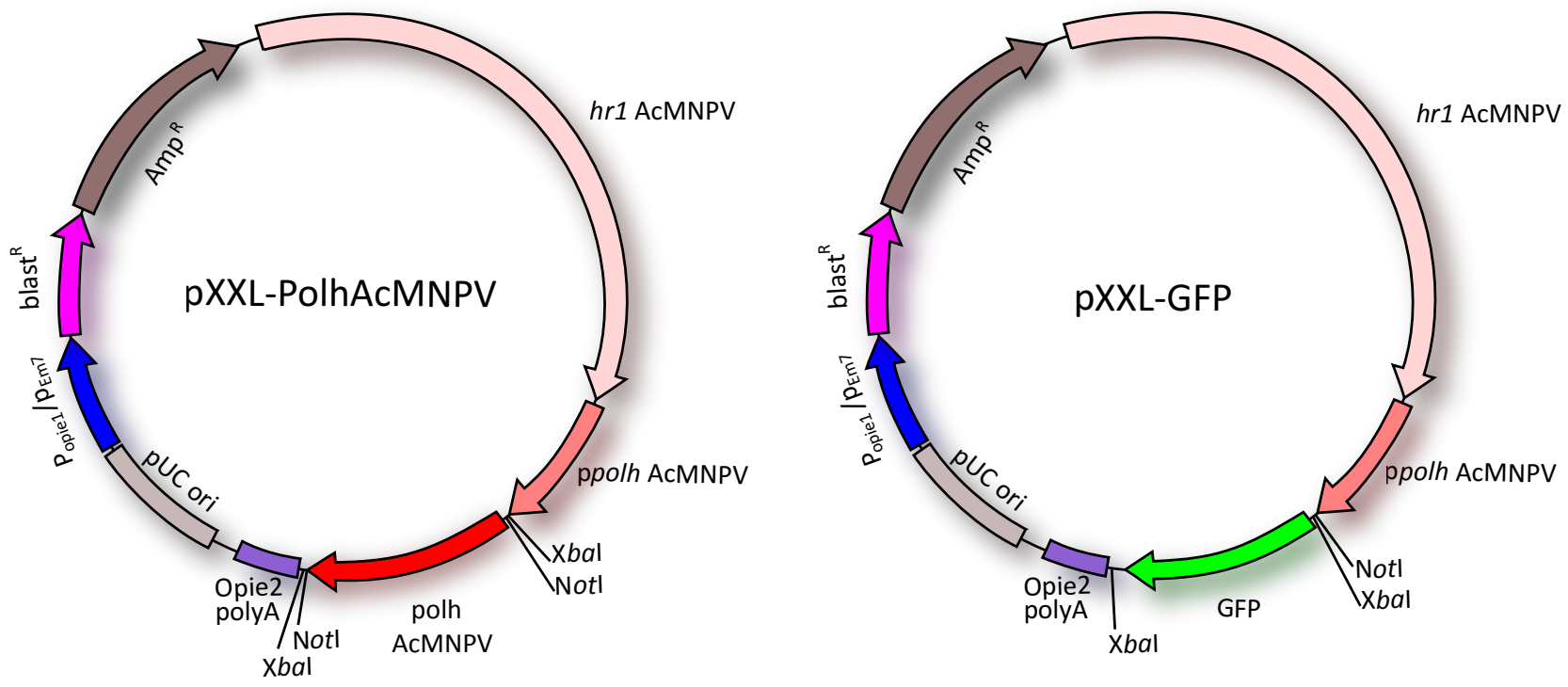

Figura 3.2: esquema de los vectores $p X X L-P o l h A c M N P V$ y $p X X L-G F P$. 
Para identificar colonias que contuvieran el plásmido recombinante, se realizó una colony PCR. Se usaron los primers Bac1 (primer forward, específico del vector. Hibrida en la región del promotor de poliedrina de AcMNPV) y polh-back (primer reverse, específico del inserto. Hibrida en la región final del ORF de poliedrina de AgMNPV) (Figura 3.3).
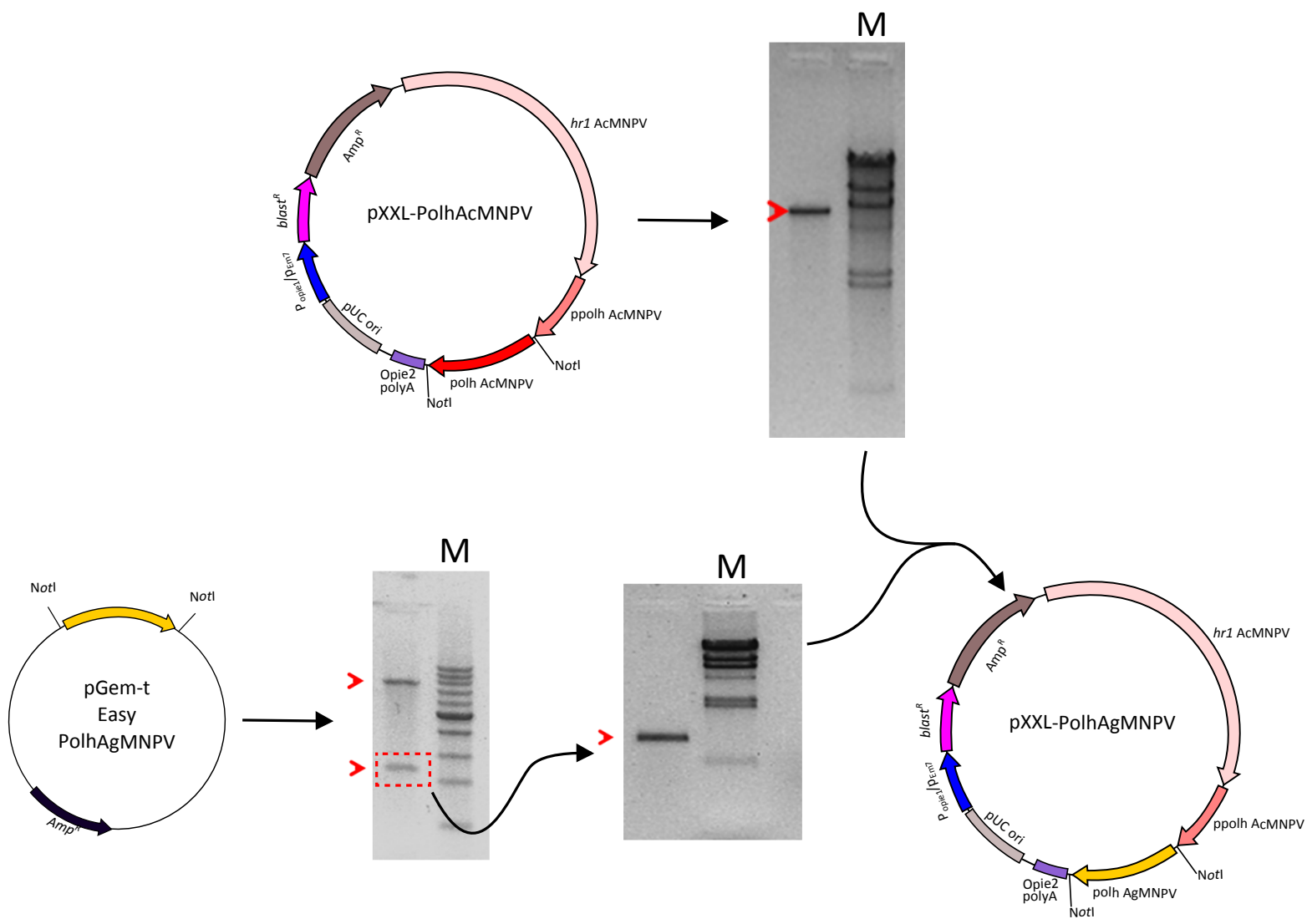

Figura 3.3: Esquema de la generación del vector pXXL-PolhAgMNPV. Como vector de partida se utilizó pXXL-PolhAcMNPV. Este plásmido se digirió con Notl para liberar el marco de lectura de la poliedrina de AcMNPV y en su lugar se clonó el ORF de la poliedrina de AgMNPV. Los productos de digestión se separaron por electroforesis en gel de agarosa. Remarcada en el gel superior se observa un gel con la banda de digestión con Notl de mayor peso de pXXL-PolhAcMNPV desfosforilada y purificada (M= marcador de peso molecular: $\lambda$ /HindIII). En los geles inferiores se observan los productos de la digestión completa con Notl del vector pGEM-T-Easy-PolhAgMNPV (izquierda) (M= marcador de peso molecular: 400 pb, Embiotec) y el producto de digesión de Notl correspondiente al ORF de poliedrina de AgMNPV purificado (derecha) ( $\mathrm{M}=$ marcador de peso molecular: $\lambda$ /HindIII). Los productos purificados fueron ligados para la generación de pXXL-PolhAgMNPV.

Para generar los vectores que expresan genes de poliedrina y GFP bajo el control de promotores de AgMNPV, se utilizó como base el vector plB (Invitrogen ${ }^{\circledR}$ ). Se amplificó 
por PCR la región hr1 de AgMNPV utilizando como molde el genoma de AgMNPV y los primers hr1AgMNPVforw y hr1AgMNPVrev. Estos primers delimitan una secuencia que se encuentra entre los nucleótidos 8042 y 9781 en el genoma de AgMNPV. Esta región fue clonada en el vector pGEM-T Easy y subclonada en el vector pIB/V5-His utilizando el sitio de restricción de EcoRI. El vector resultante se denominó plB-Hr1AgMNPV. Posteriormente, se amplificó el promotor de poliedrina de AgMNPV, utilizando los primers forwPpolhAgMNPV y revPpolhAgMNPV y se clonó en el vector pGEM-T Easy. Este promotor fue clonado luego en el vector pIB/V5-His utilizando el sitio de restricción de Notl. El plásmido resultante fue denominado plB-Hr1AgMNPVppolhAgMNPV. Este último vector contiene un gen que confiere resistencia a blasticidina como marcador para la selección de células transformadas y el promotor de poliedrina de AgMNPV expandido con la región hr1 de AgMNPV, la cual actuaría como enhancer. En este vector se clonaron independientemente los marcos de lectura (ORF) de tres diferentes genes: porteína verde fluorescente (GFP), poliedrina de AcMNPV (polhAcMNPV) y poliedrina de AgMNPV (polhAgMNPV). De esta manera se generaron los vectores de expresión y selección: plB-Hr1AgMNPV-ppolhAgMNPVGFP, pIB-Hr1AgMNPV-ppolhAgMNPV-PolhAcMNPV y plB-Hr1AgMNPV-ppolhAgMNPVpolhAgMNPV (Figura 3.4).

\subsubsection{Obtención de las líneas celulares XXL-polhAcMNPV y XXL-polhAgMNPV}

Se transfectaron células High Five ${ }^{\mathrm{TM}}$ con los plásmidos pXXL-GFP, pXXL-polhAcMNPV, pXXL-polhAgMNPV, pIB-Hr1AgMNPV-ppolhAgMNPV-GFP, pIB-Hr1AgMNPV-ppolhAgMNPVPolhAcMNPV y pIB-Hr1AgMNPV-ppolhAgMNPV-polhAgMNPV utilizando el reactivo de transfección Cellfectin II $\quad\left(\right.$ Invitrogen $\left.^{\circledR}\right)$ de acuerdo al protocolo recomendado por el fabricante (ver Anexo).

Se generaron líneas celulares derivadas de los vectores pXXL-GFP, pXXL-polhAcMNPV y pXXL-polhAcMNPV de acuerdo al protocolo de dilución terminal (ver Anexo). Estas líneas celulares se denominaron XXL-GFP, XXL-polhAcMNPV y XXL-polhAgMNPV y expresan, respectivamente, GFP, poliedrina de AcMNPV y poliedrina de AgMNPV bajo el control del promotor de poliedrina de AcMNPV extendido con la región hr1 de AcMNPV.

Cada población clonal fue repicada e infectada para observar la expresión del transgén (O'Reilly, et al., 1994), medida de manera indirecta por la formación de poliedros al 
infectar con AcMNPV-lacZ+-polh (En el caso de las líneas celulares XXL-polhAcMNPC y XXL-polhAgMNPV) o mediante la expresión de GFP en el caso de la línea celular XXL-GFP.
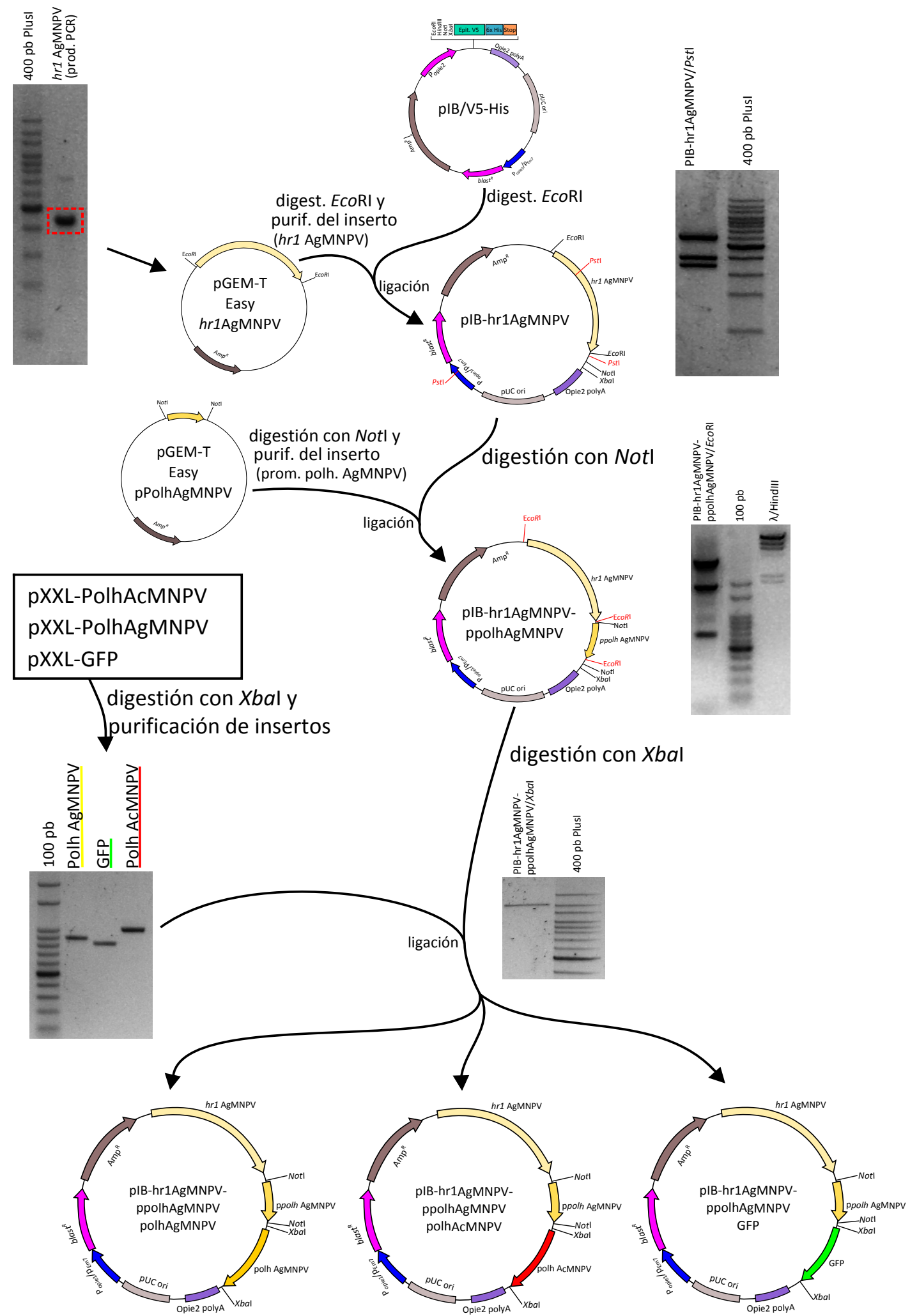

Figura 3.4: Esquema de la construcción de los vectores plB-Hr1AgMNPV-ppolhAgMNPV-polhAgMNPV, pIB-Hr1AgMNPV-ppolhAgMNPV-PolhAcMNPV y Hr1AgMNPV-ppolhAgMNPV-GFP. 
Los clones seleccionados por poseer una expresión del transgén homogénea en todas las células se sometieron a dos procesos sucesivos de clonación por dilución terminal adicionales para asegurar la homogeneidad genética de las líneas celulares obtenidas.

En el caso de las construcciones que expresan genes bajo el control de los elementos regulatorios de AgMNPV, se generaron cultivos policlonales transgénicos. Las células transfectadas con los plásmidos pIB-Hr1AgMNPV-ppolhAgMNPV-GFP, plB-Hr1AgMNPVppolhAgMNPV-PolhAcMNPV y pIB-Hr1AgMNPV-ppolhAgMNPV-polhAgMNPV se mantuvieron en medio con blasticidina $(50 \mu \mathrm{g} / \mathrm{ml})$ durante diez días para seleccionar la integración de los plásmidos en el genoma de la célula y luego fueron repicadas y utilizadas para los ensayos correspondientes.

\subsubsection{Evaluación de la expresión del gen heterólogo del virus recombinante AgMNPV-tox34-polh'}

El virus AgMNPV-tox34-polh ${ }^{-}$fue desarrollado anteriormente en nuestro laboratorio mediante el reemplazo alélico del ORF de poliedrina de AgMNPV por el ORF del gen tox34 del ácaro P. tritici (Arana, 2003). Se infectaron células High Five ${ }^{\mathrm{TM}}$ con el virus de acuerdo a los protocolos establecidos (O'Reilly et al., 1994). Luego de 4 días después de la infección, se recolectó el sobrenadante y se suspendieron las células en PBS. Las células se centrifugaron a $2000 \times \mathrm{g}$ durante 10 minutos. A alícuotas de ambas fracciones (celular y sobrenadante) se les agregó buffer de siembra $(5 x=$ Tris- $\mathrm{HCl}$ $0.25 \mathrm{M}$ pH 6.8., SDS $15 \%$, glicerol $50 \%$, $\beta$-mercaptoetanol $25 \%$ y azul de bromofenol $0.01 \%$ ) y las proteínas se resolvieron mediante SDS-PAGE. Se utilizó el marcador de peso molecular de rango amplio (Broad Range Unstained) de Bio-Rad.

\subsubsection{Ensayos de niveles de activación transcripcional y oclusión de virus poliedrina negativo (pol $\left.h^{-}\right)$en cultivos complementadores.}

Para comparar los niveles de activación de los promotores clonados por parte de los factores transcripcionales de las dos especies de virus evaluadas, se infectó en una primera etapa la línea celular XXL-GFP con los virus AcMNPV y AgMNPV, siguiendo los protocolos estándar. En otro ensayo, se infectó el cultivo celular transgénico generado a partir de la construcción plB-Hr1AgMNPV-ppolhAgMNPV-GFP con el virus AgMNPV. 
96 horas después de la infección, se analizó el nivel de expresión de GFP por microscopía de fluorescencia.

Para evaluar la complementación funcional de virus deficientes a partir de los cultivos celulares que expresan genes de poliedrina, se utilizaron los recombinantes AcMNPV-lacZ-polh y AgMNPV-tox34-polh'. El primero expresa además el gen de la $\beta$-galactosidasa de E. coli mientras el segundo expresa la toxina tox34 del ácaro $P$. tritici. El virus AcMNPV-lacZ-polh' se utilizó para infectar las líneas celulares XXL-polhAcMNPV y XXL-polhAgMNPV. El virus AgMNPV-tox34-polh' se utilizó para infectar las líneas celulares XXL-polhAcMNPV, XXL-polhAgMNPV y los cultivos transgénicos policlonales derivados de las construcciones pIB-Hr1AgMNPV-ppolhAgMNPV-PolhAcMNPV y pIBHr1AgMNPV-ppolhAgMNPV-polhAgMNPV. Luego de siete días se analizó por microscopía la presencia de cuerpos de oclusión en los cultivos celulares infectados.

\subsubsection{Evaluación de la infectividad oral de los cuerpos de oclusión complementados} de AcMNPV-lacZ-polh' complementados en las líneas celulares XXL-PolhAcMNPV y XXL-PolhAgMNPV en larvas de Rachiplusia nu

Para evaluar la capacidad infectiva oral, se realizó la extracción de los cuerpos de oclusión a partir de cultivo celular de acuerdo a los protocolos establecidos (O'Reilly et al., 1994). Se utilizaron cultivos de las líneas celulares XXL-PolhAcMNPV y XXL-PolhAgMNPV infectados con AcMNPV-lacZ-polh ${ }^{-}$y como control positivo se utilizaron OB purificados de células High Five ${ }^{\mathrm{TM}}$ infectadas con AcMNPV-wt.

Se prepararon suspensiones de $\mathrm{OB}$ en agua destilada con Coomassie brilliant blue $1 \%(p / v)$ como colorante y sacarosa $1 \%(p / v)$ como fagoestimulante. Las preparaciones se administraron por vía oral a 40 larvas del tercer estadio de Rachiplusia nu siguiendo el método de la alimentación por gotas (Hughes y Wood, 1981). Teniendo en cuenta el volumen promedio ingerido por las larvas de $R$. nu en tercer estadio (Kunimi y Fuxa, 1996), se utilizó una suspensión de OB de una concentración adecuada para administrar 1000 OB a cada larva.

Cuatro días después de la infección, algunas larvas fueron disecadas y se extrajo el tejido intestinal y la hemolinfa. Estos tejidos fueron teñidos con X-gal (5-bromo-4cloro-3-indolil- $\beta$-D-galactopiranósido) para observar actividad $\beta$-galactosidasa. Para ello, 
se extendieron sobre un portaobjetos los tejidos y se lavaron con $1 \mathrm{ml}$ de PBS $1 \mathrm{X}$ y se incubaron durante $5 \mathrm{~min}$ a temperatura ambiente con $500 \mu \mathrm{l}$ de solución fijadora (formaldehído $2 \%(\mathrm{v} / \mathrm{v})$, glutaraldehído $0,2 \%$ (v/v), en PBS). A continuación, se lavaron 2 veces con $1 \mathrm{ml}$ de PBS y se incubaron con $1 \mathrm{ml}$ de solución de tinción (ferricianuro de potasio $5 \mathrm{mM}$, ferrocianuro de potasio $5 \mathrm{mM}, \mathrm{MgCl}_{2} 2 \mathrm{mM}$ y X-gal $1 \mathrm{mg} / \mathrm{ml}$ ) durante 2 horas a $37^{\circ} \mathrm{C}$. Finalmente, los preparados se observaron al microscopio en campo claro.

\subsection{Resultados}

Inicialmente, se utilizaron dos vectores de transferencia. Uno de ellos, desarrollado previamente por la Dra. Gabriela López en el grupo de trabajo del Dr. Oscar Taboga (López et al., 2010), contiene el marco de lectura del gen de poliedrina de AcMNPV bajo el control de su propio promotor, ampliado con una región hr1 de AcMNPV. Este vector se utilizó para intercambiar el ORF de poliedrina de AcMNPV por el de AgMNPV, conservando las regiones regulatorias de AcMNPV.

Utilizando estas construcciones, se generaron dos líneas celulares transgénicas. Una de ellas expresa la poliedrina de AcMNPV y la otra expresa la poliedrina de AgMNPV.

Para evaluar la complementación funcional entre los genes de poliedrina de las dos especies, se infectaron las líneas celulares que expresa la poliedrina de AgMNPV y AcMNPV (XXL-polhAgMNPV y XXL-polhAcMNPV) con un virus AcMNPV deficiente en poliedrina $\left(p o l h^{-}, \operatorname{lac}^{+}\right)$. En ambas infecciones se observó la formación de cuerpos de oclusión de tamaño y forma regular en los núcleos de las células infectadas. La eficiencia de oclusión fue, además, muy elevada. Luego de 96 horas de infección se observaron OB en más del $90 \%$ de las células (Figuras 3.5 y 3.6).

Los poliedros generados en estas infecciones se purificaron y administraron por vía oral a larvas de Rachiplusia nu, susceptibles a AcMNPV. Se comprobó que la administración oral de OB a dosis más de diez veces superiores a la dosis letal media, ocasionó el 100\% de mortalidad de las larvas. Además, se observó que las larvas infectadas expresaban lacz en el tejido intestinal y en células de la hemolinfa (Figura 3.7). Estos resultados demuestran que la poliedrina de AcMNPV puede ser complementada con la proteína homóloga de AgMNPV. La complementación da lugar a cuerpos de oclusión con morfología normal que son infectivos por vía oral. 


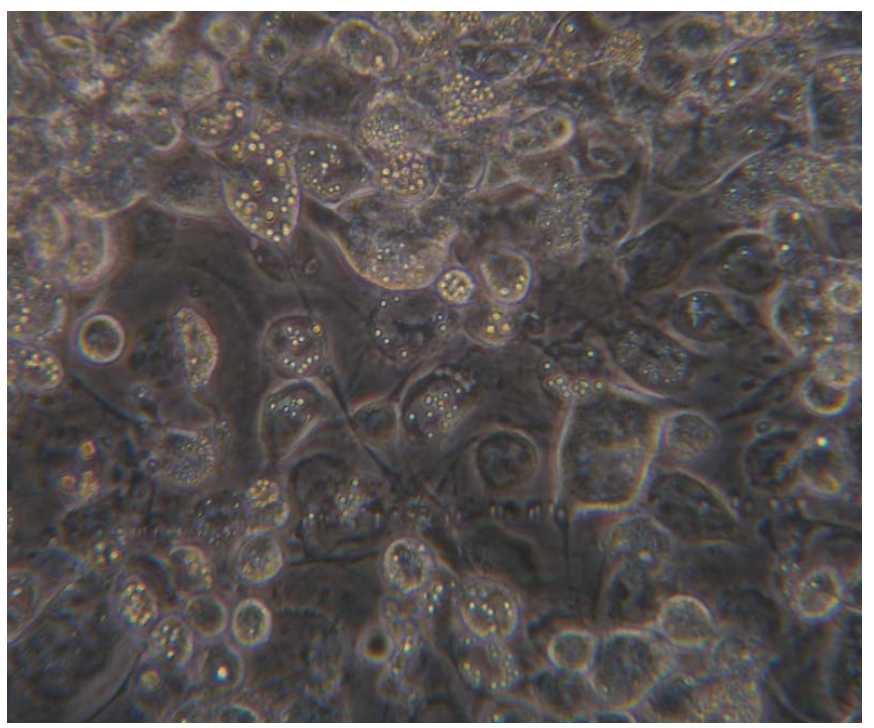

Figura 3.5. Microscopia de la línea celular transgénica pXXL-polhAcMNPV infectada con el virus AcMNPV-lac $Z^{+}-$polh ${ }^{-}$.

a

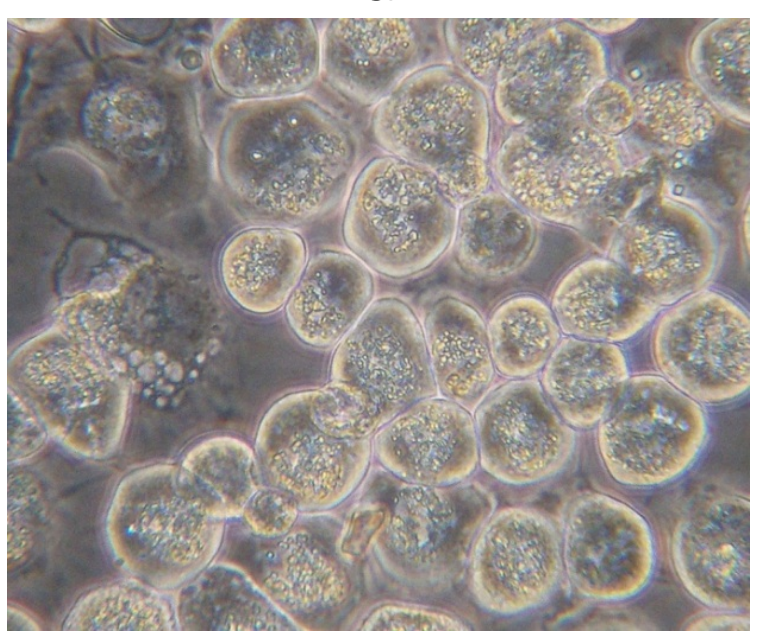

b

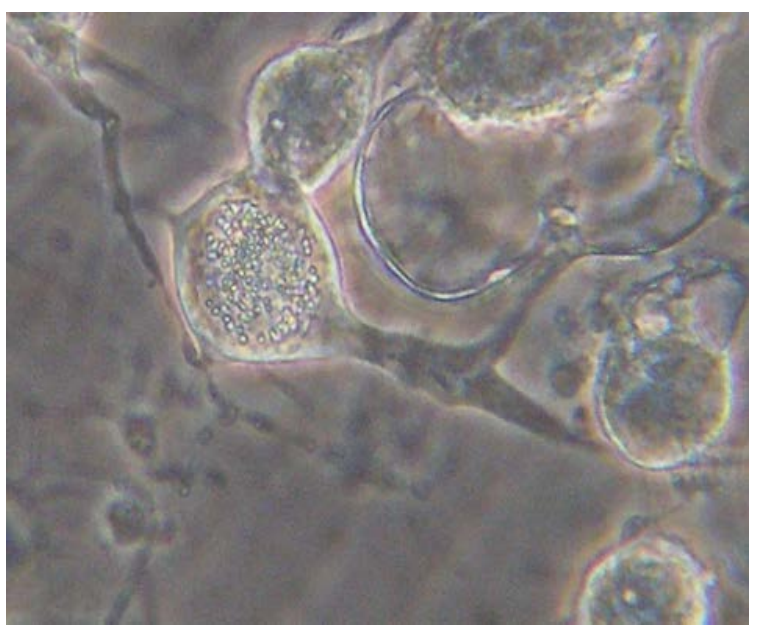

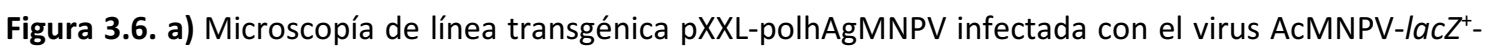
polh ${ }^{-}$. b) Microscopía de línea transgénica pXXL-polhAcMNPV, infectado con el virus AgMNPV-polh' ${ }^{-}$. En ambos casos se evidencia la aparición de cuerpos de oclusión en el núcleo de las células.

Por otra parte, se infectó la línea celular que expresa la poliedrina de AcMNPV con un virus AgMNPV deficiente en poliedrina ( $\left.p o / h^{-}\right)$. En este caso, se observaron muy pocas células con cuerpos de oclusión de tamaño pequeño en su interior (Figura 3.6). Esto podría deberse a que el promotor de poliedrina de AcMNPV no es activado de manera eficiente por los factores transcripcionales de AgMNPV (y no se consigue la concentración de poliedrina en la célula requerida para iniciar la cristalización y la formación de $O B$ ) o que las células High Five ${ }^{\mathrm{TM}}$ no son altamente susceptibles a AgMNPV (Mengual Gómez, 2013). 

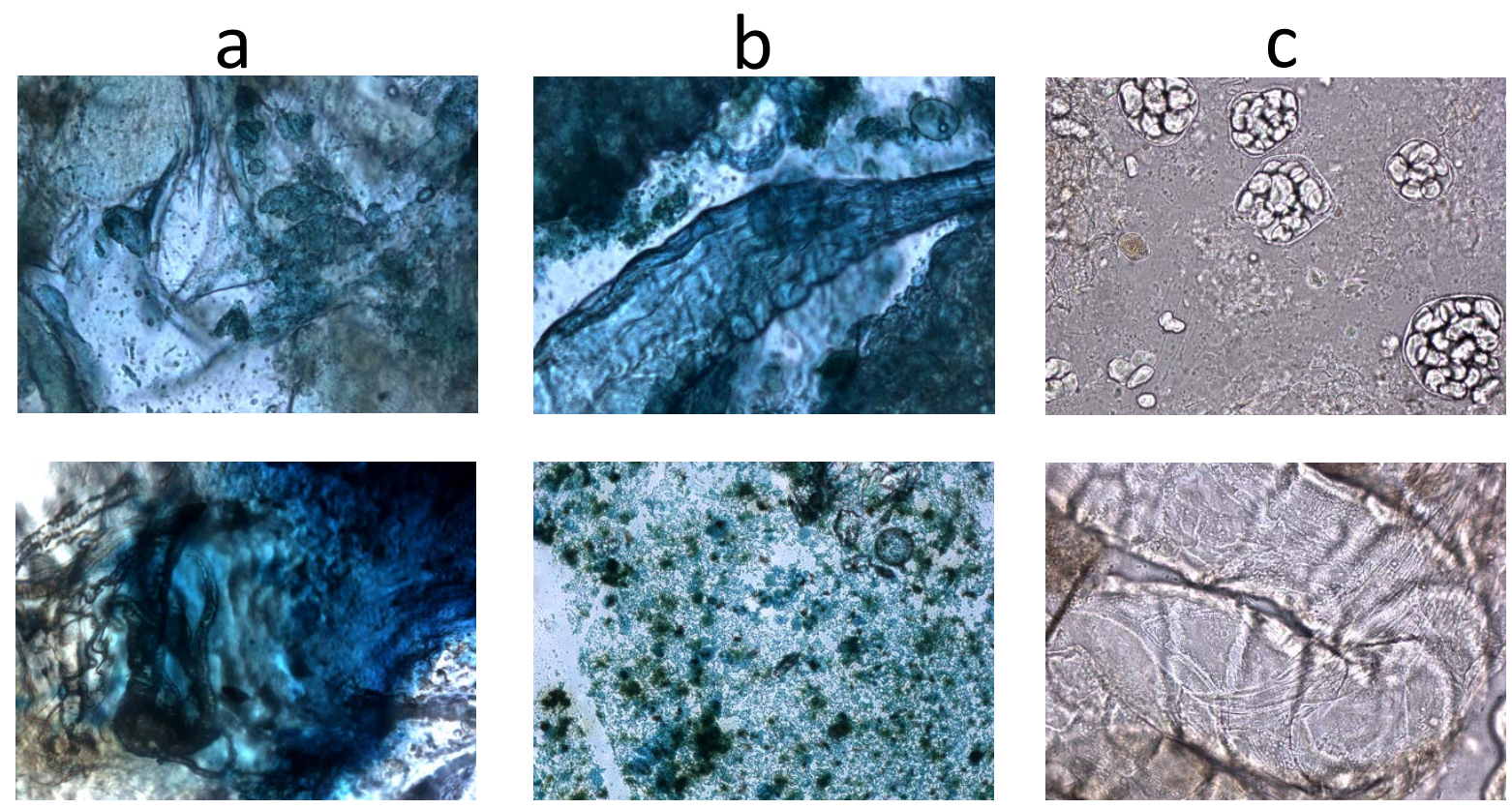

Figura 3.7. Microscopía de tejidos extraídos de larvas de Rachiplusia nu y teñidos para observar actividad $\beta$-galactosidasa. Las larvas fueron infectadas con a) AcMNPV-lacZ-polh- ocluido con la línea transgénica pXXL-polhAcMNPV b) AcMNPV-lacZ-polh ocluido con la línea transgénica pXXL-polhAgMNPV c) AcMNPV-wt (control).

Para averiguar a cuál de estas opciones se debía la ineficiencia de la oclusión de AgMNPV en las líneas complementadoras, se generó una línea celular que expresa GFP bajo el control del promotor de poliedrina extendido de AcMNPV, utilizando el vector pXXL-GFP, gentilmente cedido por los Dres. Gabriela López y Oscar Taboga (López et al., 2010). Los ensayos de expresión utilizando esta línea transgénica mostraron que los niveles de expresión conseguidos al infectar con AgMNPV son inferiores a los que se consiguen al infectar con AcMNPV (Figura 3.8).

Por esta razón, se consideró la posibilidad de aumentar los niveles de expresión produciendo líneas celulares con promotores y secuencias repetitivas ( $h r s$ ) de AgMNPV. Esto condujo al desarrollo de nuevos vectores que expresan los genes de poliedrina de ambas especies (AcMNPV y AgMNPV) bajo el control de un promotor de poliedrina de AgMNPV extendido con la región repetitiva hr1 de AgMNPV (Figura 3.4). Los niveles de activación de este promotor fueron evaluados utilizando un cultivo celular transformado con una construcción que expresa GFP. Como se esperaba, al infectar con AgMNPV los niveles de expresión de GFP fueron mayores en el cultivo celular transformado con una construcción que contiene el promotor de AgMNPV que en el transformado con una construcción que contiene el promotor de AcMNPV ( $p X X L-G F P)$. 

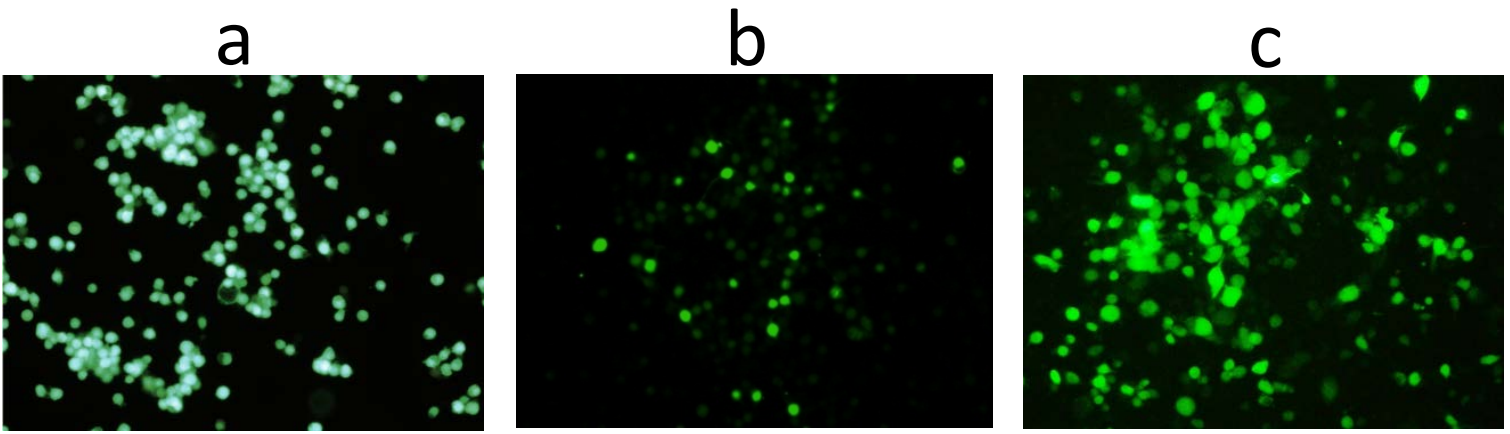

Figura 3.8. Comparación de los niveles de expresión de GFP en las líneas pXXL-GFP infectada con AcMNPV (a) y AgMNPV (b) y el cultivo celular derivado del vector plB-Hr1AgMNPV-ppolhAgMNPVGFP infectado con AgMNPV (c).

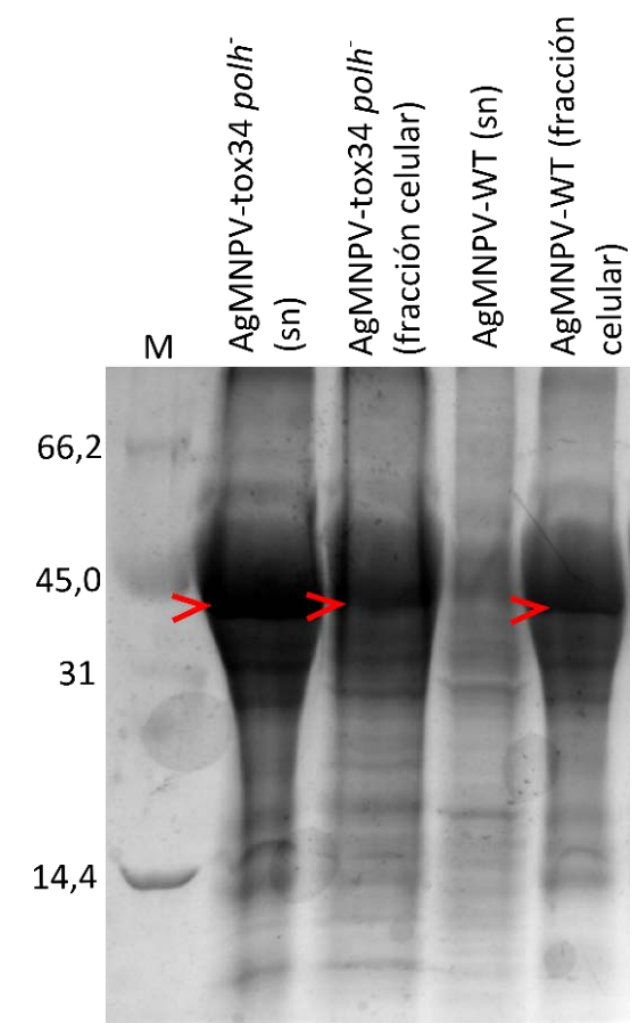

Figura 3.9. Evaluación de la expresión de TxP-I en células infectadas con el virus AgMNPV-tox34-polh ${ }^{-}$en sobrenadante (sn) y fracción celular. La banda mayoritaria (40 kDa) (resaltada) en ambas fracciones corresponde a la proteína TxP-I. Como control se utilizó el virus AgMNPV-wt, en el cual se observa la banda de poliedrina (resaltada) sólo en la fracción celular. Se marcó el peso en $\mathrm{kDa}$ de las bandas relevantes del marcador de peso molecular.
Se consideró la posibilidad de utilizar las líneas celulares que expresan poliedrina para generar cuerpos de oclusión de AgMNPV-tox34-polh', un virus desarrollado anteriormente en nuestro laboratorio que no pudo ser evaluado como bioinsecticida por la incapacidad de formar cuerpos de oclusión (Arana, 2003). Se decidió evaluar la expresión del gen tox34 por en células infectadas con este virus, encontrando una concentración de proteína elevada en el interior de la célula y en el medio de cultivo sobrenadante (Figura 3.9). Esto implica que las células High Five ${ }^{\mathrm{TM}}$ procesan y direccionan el producto polipeptídico de tox34 (TxP-I) adecuadamente, por lo cual es muy probable que la toxina sea biológicamente activa $y$ permita mejorar la capacidad insecticida del virus. Posteriormente, se infectaron los cultivos transgénicos derivados de las construcciones pIB-Hr1AgMNPV-ppolhAgMNPV-PolhAcMNPV y pIB-Hr1AgMNPV-ppolhAgMNPV-polhAgMNPV 
con AgMNPV-tox34-polh y luego de siete días se observó la presencia de OB en las células infectadas de ambos cultivos. A diferencia de lo observado con la infección de la línea celular pXXL-polhAgMNPV con AgMNPV $\left(\right.$ pol $\left.h^{-}\right)$, en este caso los OB observados presentaron un tamaño regular al complementar con los genes de poliedrina de las dos especies (Figura 3.10).

$$
\begin{gathered}
\text { pIB-hr1AgMNPV- } \\
\text { ppolhAgMNPV- } \\
\text { polhAgMNPV }
\end{gathered}
$$
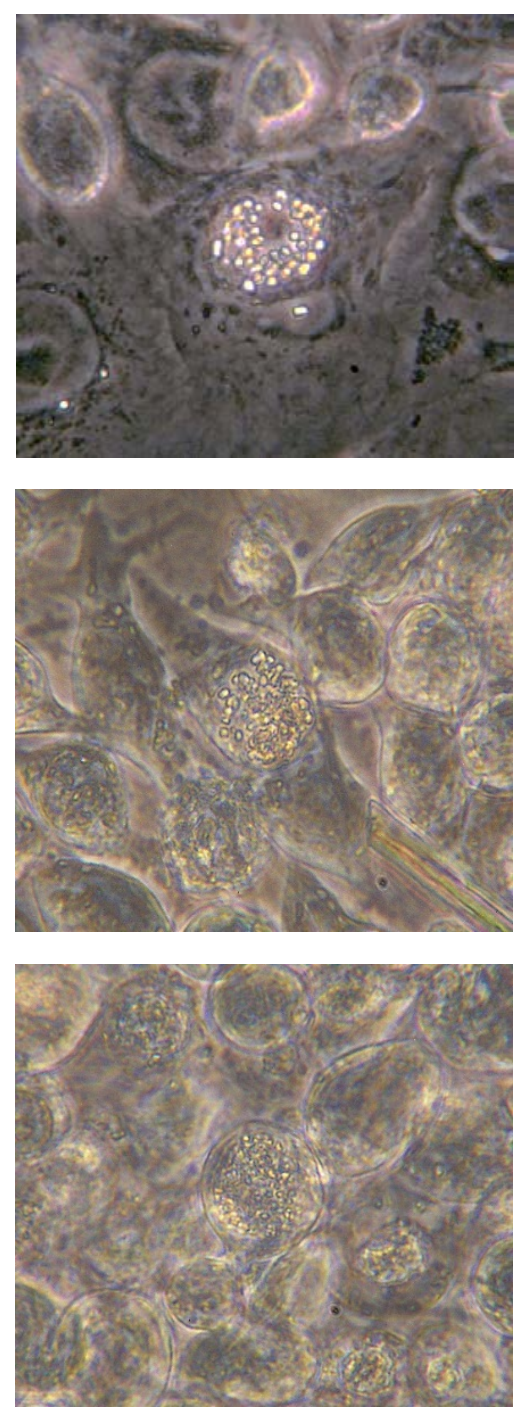

pIB-hr1AgMNPVppolhAgMNPVpolhAcMNPV
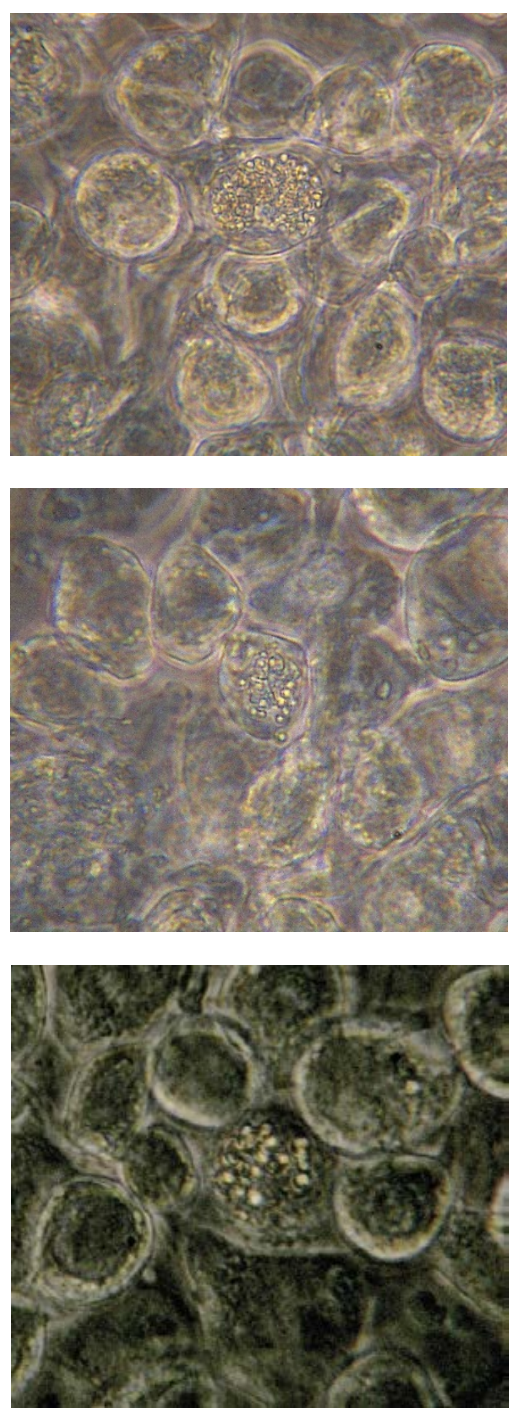

Figura 3.10. Microscopía de los cultivos transgénicos derivados de los vectores Hr1AgMNPVppolhAgMNPV-PolhAcMNPV y plB-Hr1AgMNPV-ppolhAgMNPV-polhAgMNPV infectados con el virus AgMNPV-tox34-polh ${ }^{-}$. Se observan cuerpos de oclusión regulares en ambos casos. 
Por una parte, se confirmó que existe reconocimiento de la poliedrina de AcMNPV por los viriones de AgMNPV y oclusión. Por otra parte, estos resultados confirman que la ineficiencia en la complementación de AgMNPV $\left(p o / h^{-}\right)$con las líneas pXXLpolhAgMNPV y pXXL-polhAgMNPV se debe al bajo nivel de reconocimiento del promotor de AcMNPV por los factores de transcripción de AgMNPV.

\subsection{Discusión}

Se desarrollaron dos líneas celulares que expresan la poliedrina de AgMNPV y AcMNPV, respectivamente, bajo el control del promotor de poliedrina de AcMNPV. La infección de la línea celular transgénicas XXL-polhAgMNPV con el virus AcMNPV-lacZ+-polh-, dio lugar a la formación de cuerpos de oclusión. A su vez, la infección de la línea celular transgénicas XXL-polhAcMNPV con el virus AgMNPV-polh-tox34, también dio lugar a la formación de cuerpos de oclusión. Los poliedros de AcMNPV-polh empaquetados con la poliedrina de AgMNPV son capaces de infectar larvas susceptibles por vía oral, conduciendo a su muerte. Esto indica que la poliedrina de AgMNPV puede complementar funcionalmente a su par de AcMNPV.

Además, se generó una línea celular (XXL-PolhAcMNPV) que expresa la poliedrina de AcMNPV bajo control del promotor extendido de poliedrina de AcMNPV. Al infectar esta línea celular con AcMNPV se observó una producción regular de poliedros. Sin embargo, al infectar esta línea celular con AgMNPV, se observó un número muy bajo de células con cuerpos de oclusión de tamaño pequeño. Esto podría deberse a un bajo nivel de reconocimiento del promotor de AcMNPV por parte de los factores transcripcionales de AgMNPV.

Por esta razón, se generaron vectores con elementos regulatorios de AgMNPV conduciendo la expresión de los ORF de poliedrina de AgMNPV, AcMNPV y GFP. Las construcciones se utilizaron para generar cultivos celulares transgénicos. Los cultivos celulares transgénicos generados con estos nuevos vectores permitieron la oclusión de AgMNPV-polh- en poliedros que son indistinguibles de los de AgMNPV-wt. En particular, se consiguió ocluir el virus recombinante AgMNPV-tox34-polh', desarrollado anteriormente en nuestro laboratorio. Se espera que este virus, al expresar tox34, posea una capacidad insecticida mejorada, aunque aún no se ha evaluado la infectividad oral de estos poliedros ni su actividad insecticida sobre larvas de $A$. gemmatalis. 
La generación de líneas celulares que expresan la poliedrina de AgMNPV tiene un gran potencial biotecnológico, ya que permite la oclusión de virus deficientes en poliedrina. Cuando estos virus ocluidos son ingeridos por las larvas, en éstas no se producen poliedros, limitando la transmisión de la infección a otras larvas. Se ha demostrado el bajo nivel de persistencia de los genomas deficientes en poliedrina (Wood et al., 1994; Inceoglu et al., 2001, 2006) en el ambiente, de manera que se podría utilizar esta tecnología para la aplicación contenida de baculovirus recombinantes a campo.

Los resultados obtenidos muestran además que existe una complementación funcional entre la poliedrina de especies heteróloga (AgMNPV y AcMNPV) y abren posibilidades hacia un estudio detallado de los mecanismos que determinan la interacción entre la poliedrina y los viriones del baculovirus. En este marco, el sistema de estudio utilizado, a través de líneas celulares transgénicas ha demostrado ser muy conveniente para investigar este tipo de fenómenos. 


\subsection{Referencias}

Arana, E. I. (2003). Desarrollo de vectores para la construcción de recombinantes del virus de la poliedrosis nuclear de Anticarsia gemmatalis (oruga de las leguminosas). Tesis Doctoral, Universidad Nacional de La Plata.

Eason, J.E.; Hice, R.H.; Johnson, J.J.; Federici, B.A. (1998). Effects of substituting granulin or a granulinpolyhedrin chimera for polyhedrin on virion occlusion and polyhedral morphology in Autographa californica multinucleocapsid nuclear polyhedrosis virus. J. Virol., 72 (7), 6237-6243.

Gonzalez, M.A.; Smith, G.E.; Summers, M.D. (1989). Insertion of the SfMNPV polyhedrin gene into an AcMNPV polyhedrin deletion mutant during viral infection. Virology, 170 (1), 160-175.

Guarino, L.A.; Gonzalez, M.A.; Summers, M.D. (1986). Complete Sequence and Enhancer Function of the Homologous DNA Regions of Autographa californica Nuclear Polyhedrosis Virus. J. Virol., 60 (1), 224-229.

Hughes, P.R. y Wood, H.A. (1981). A synchronous peroral technique for the bioassay of insect viruses. J. Invertebr. Pathol., 37, 154-159.

Inceoglu, A.B.; Kamita, S.G.; Hinton, A.C.; Huang, Q.H.; Severson, T.F.; Kang, K.D.; Hammock, B.D. (2001) Recombinant baculoviruses for insect control. Pest Manag. Sci., 57 (10), 981-987.

Inceoglu A.B.; Kamita S.G.; Hammock B.D. (2006) Genetically modified baculoviruses: a historical overview and future outlook. Adv. Virus Res., 68, 323-360.

Kunimi, Y. y Fuxa, J.R. (1996). Volumes ingested by four species of noctuids with reference to peroral droplet bioassay of baculoviruses. J. Invertebr. Pathol., 68 (3), 310-311.

López, M.G.; Alfonso, V.; Carrillo, E.; Taboga, O. (2010). Trans-complementation of polyhedrin by a stably transformed Sf9 insect cell line allows occ- baculovirus occlusion and larval per os infectivity. J. Biotechnol., 145 (2), 199-205.

Maruniak, J.E.; Garcia-Canedo, A.; Rodrigues, J.J. (1994). Cell lines used for the selection of recombinant baculovirus. In Vitro Cell. Dev. Biol. Anim., 30a (4), 283-286.

Mengual Gómez, D. (2013) Virus de la poliedrosis nuclear múltiple de Anticarsia gemmatalis: Proteómica estructural e impacto del hospedador en su producción in vitro. Tesis doctoral. Universidad Nacional de Quilmes.

O'Reilly, D.R.; Miller, L.K.; Luckow, V.A. (1994). Baculovirus Expression Vectors: A Laboratory Manual. Oxford University Press. 347 pages.

Wickham, T.J.; Davis, T.; Granados, R.R.; Shuler, M.L.; Wood, H.A. (1992). Screening of insect cell lines for the production of recombinant proteins and infectious virus in the baculovirus expression system. Biotechnol. Prog., 8 (5), 391-396.

Wood, H.A.; Hughes, P.R.; Shelton, A. (1994). Field studies of the co-occlusion strategy with a genetically altered isolate of the Autographa californica nuclear polyhedrosis virus. . Environ. Entomol., 23 (2), 211219.

Yu, M. y Carstens, E.B. (2012). Choristoneura fumiferana multiple nucleopolyhedrovirus LEF-3-P143 complex can complement DNA replication and budded virus in an AcMNPV LEF-3-P143 double knockout bacmid. J. Gen. Virol., 93 (Pt 2), 383-388. doi: 10.1099/vir.0.036699-0

Zhou, C. E.; Ko, R.; Maeda, S. (1998). Polyhedron-like inclusion body formation by a mutant nucleopolyhedrovirus expressing the granulin gene from a granulovirus. Virology, 240 (2), 282-294. 


\section{Capítulo 4}

\section{Desarrollo de una línea celular para la titulación y el monitoreo de infecciones de baculovirus}





\subsection{Introducción}

El mantenimiento y la modificación genética de los baculovirus se llevan a cabo normalmente en cultivos celulares derivados de lepidópteros. Las líneas celulares más populares para la manipulación de baculovirus son High Five ${ }^{T M}$, derivada de células de ovario del lepidóptero Trichoplusia ni y Sf9, derivada de células de ovario del lepidóptero Spodoptera frugiperda y permiten la replicación de varios poliedrovirus.

El aislamiento de baculovirus recombinantes y las titulaciones en cultivo celular requieren que las células infectadas se puedan diferenciar fácilmente de células no infectadas. Sin embargo, el fenotipo del baculovirus no siempre se diferencia visualmente y las placas de infección no son distinguibles si el baculovirus no expresa el gen de la poliedrina. Por esta razón, resulta útil el desarrollo de líneas celulares transgénicas que expresen genes indicadores inducibles por la infección viral. Para lograr la inducción controlada del gen indicador, se utilizan los promotores virales tardíos, que requieren de factores virales para su transcripción.

Los métodos de titulación de baculovirus más aplicados actualmente se basan en la cuantificación de genomas virales por PCR en tiempo real (qPCR). Estos métodos, aunque son rápidos y relativamente sencillos, poseen la desventaja de que no permiten diferenciar viriones defectivos o inviables de los viriones viables, que son los que realmente poseen la capacidad de penetrar en una célula susceptible e iniciar un ciclo replicativo. Por esta razón, los métodos de cuantificación basados en qPCR tienden a sobreestimar los títulos virales.

Los métodos de titulación por plaqueo son más confiables, porque permiten determinar la cantidad de partículas infectivas viables de una muestra. Sin embargo, son más lentos y las técnicas involucradas resultan más complejas que las de qPCR. La disponibilidad de una línea celular que expresa un gen indicador inducible por infección que pueda ser detectado por técnicas no invasivas permite la exploración de nuevos métodos de titulación automatizados que podrían ser aplicados por cualquier laboratorio como prácticas estándar. 
En este capítulo se describe el desarrollo de una línea celular derivada de High Five ${ }^{\mathrm{TM}}$ que expresa la proteína fluorescente verde (GFP) bajo el control del promotor de poliedrina del nucleopoliedrovirus de Autographa californica (AcMNPV) y su aplicación en la clonación de virus recombinantes y el monitoreo y titulación de stocks virales. Si bien otro grupo de investigación ha descripto anteriormente el desarrollo de una línea celular que expresa GFP bajo el promotor de poliedrina de AcMNPV basada en Sf-9 (Hopkins y Esposito, 2009), ese trabajo carece de una caracterización detallada de la línea celular como la que es abordada en este capítulo. Además, la línea High Five ${ }^{\mathrm{TM}}$ presenta algunas ventajas en comparación con la línea celular Sf9. Entre ellas se puede destacar una mayor viabilidad frente a la infección, un mayor nivel de expresión de proteínas heterólogas y una mayor eficiencia de captación de virus brotantes (Wickham et al., 1992; Maruniak, et al., 1994).

\subsection{Materiales y Métodos}

\subsubsection{Plásmido $\mathrm{pXXL-GFP}$}

El plásmido de selección utilizado para la generación de la línea celular transgénica, denominado pXXL-GFP, fue gentilmente cedido por los doctores Taboga y López (INTACastelar) (López et al., 2010). Este vector contiene el marco de lectura de la proteína GFP bajo el control del promotor de poliedrina de AcMNPV. Para proveer un nivel de expresión mayor, se adicionó al plásmido la región hr1 de AcMNPV (ver Capítulo 3).

\subsubsection{Obtención de la línea celular XXL-GFP}

Se transfectaron células High Five ${ }^{\mathrm{TM}}$ con el plásmido pXXL-GFP utilizando el reactivo de transfección Cellfectin II (Invitrogen ${ }^{\circledR}$ ) de acuerdo al protocolo recomendado por el fabricante (ver Anexo). A partir de las células transfectadas, se generaron líneas celulares derivadas de los vectores pXXL-GFP de acuerdo al protocolo de dilución terminal (ver Anexo).

Para verificar que los aislamientos seleccionados correspondieran a poblaciones clonales, se infectaron estas líneas celulares con un virus AcMNPV que expresa la proteína roja fluorescente. El proceso aislamiento clonal por dilución serial se volvió a 
repetir dos veces más para los clones seleccionados. La línea celular transgénica desarrollada se denominó XXL-GFP.

\subsubsection{Evaluación de la activación de la expresión en la línea transgénica XXL-GFP infectada con AgMNPV}

Se infectó la línea celular transgénica con el virus AgMNPV-I-Ppol para evaluar si los factores transcripcionales de AgMNPV pueden activar el promotor de poliedrina de AcMNPV que dirige la expresión de GFP en la línea transgénica. La detección de la expresión de GFP se realizó mediante microscopía de fluorescencia.

\subsubsection{Evaluación de la estabilidad genética de la línea XXL-GFP}

La línea celular XXL-GFP fue sometida a 30 pasajes en medio sin antibiótico. Cada 10 pasajes se infectó la línea con el virus AcMNPV-DsRed, que expresa la proteína roja fluorescente y se evaluó la expresión de GFP y DsRed simultáneamente por microscopía de fluorescencia.

\subsubsection{Ensayos de titulación}

Se infectaron monocapas de la línea transgénica XXL-GFP para su evaluación en titulaciones por dilución terminal y plaqueo (O'Reilly et al., 1994). Las titulaciones fueron reveladas con un transiluminador convencional con filtro de $320 \mathrm{~nm}$ acoplado a un equipo de adquisición de imágenes.

\subsection{Resultados}

Se generó una línea celular que contiene el gen indicador gfp bajo el control del promotor de poliedrina de AcMNPV (Figura 4.1). Este promotor es activado únicamente por factores transcripcionales del virus, por lo que la expresión de GFP se convierte en este caso en un indicador de infección de la célula.

Para asegurar la uniformidad genética de la línea celular XXL-GFP se repitió tres veces el clonado por dilución terminal. 
a

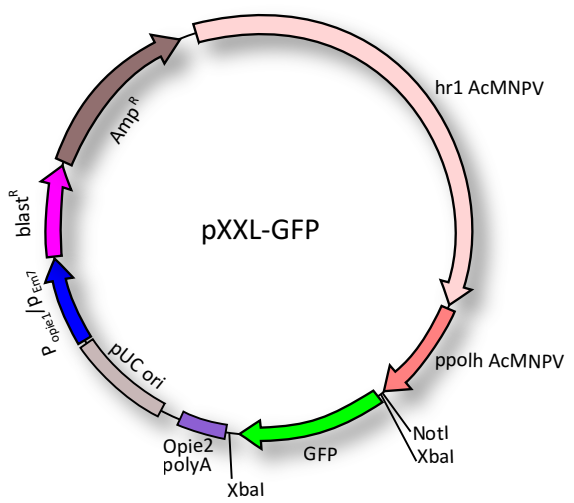

b

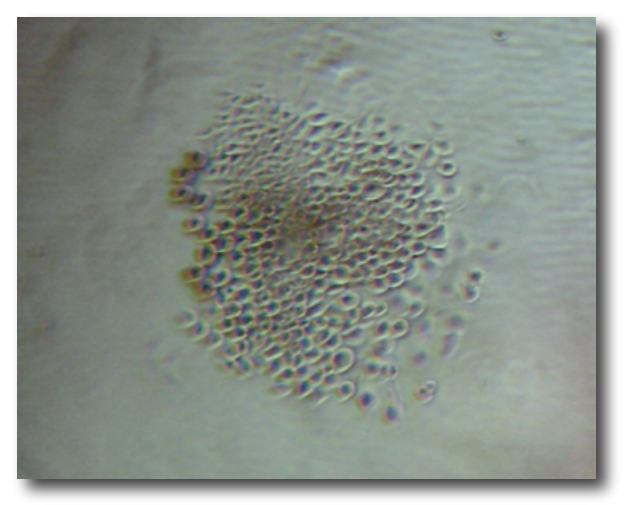

Figura 4.1. a) Vector de selección utilizado para la generación de la línea celular XXL-GFP. b) Microcolonia de células High Five ${ }^{\mathrm{TM}}$ transfectadas con el vector pXXL-GFP y seleccionadas con el antibiótico blasticidina.

Para verificar que todas las células infectadas expresan uniformemente el gen heterólogo, se utilizó un AcMNPV recombinante que expresa en su genoma el gen de la proteína roja fluorescente DsRed bajo el control del promotor de poliedrina. Al infectar la línea celular XXL-GFP con este virus, se observa que todas las células en las cuales se observa fluorescencia roja (infectadas) también se observa fluorescencia verde (Figura 4.2).

Posteriormente, se analizó la activación de las secuencias regulatorias del transgén en la línea celular, que provienen del gen de poliedrina de AcMNPV, por los factores transcripcionales de AgMNPV. Se observó un nivel inferior en la expresión de GFP comparándolo con la infección de la línea XXL-GFP con AcMNPV (Figura 4.3). Esto puede deberse a un reconocimiento menos eficiente del promotor heterólogo o a que el ciclo replicativo de AgMNPV es menos eficiente en células High Five $^{\mathrm{TM}}$ que el de AcMNPV. Sin embargo, los niveles observados son suficientes para permitir el uso de esta línea para clonar, titular y monitorear AgMNPV.

Se comprobó la estabilidad genética de la línea celular XXL-GFP mantenida sin agente de selección a lo largo de los pasajes celulares. Durante 30 pasajes no se observó variación en la expresión de GFP en células infectadas o variaciones en la proporción de células infectadas que no expresan GFP (Figura 4.4). 
a

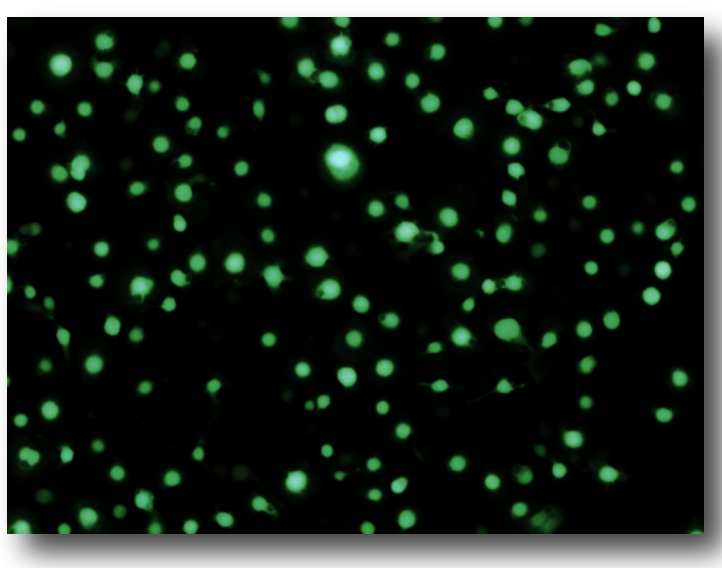

b

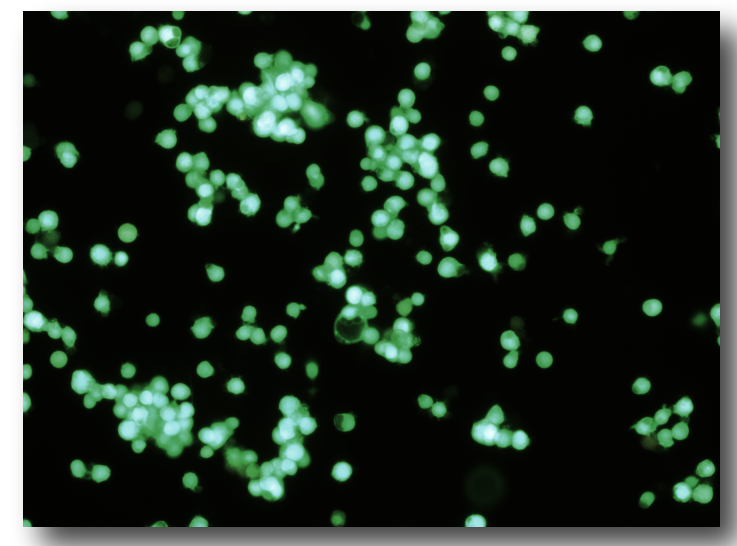

ii)

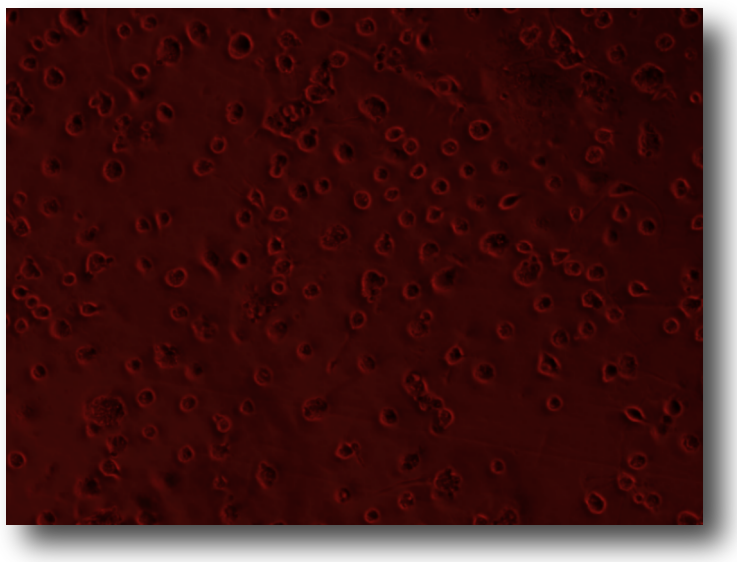

ii)

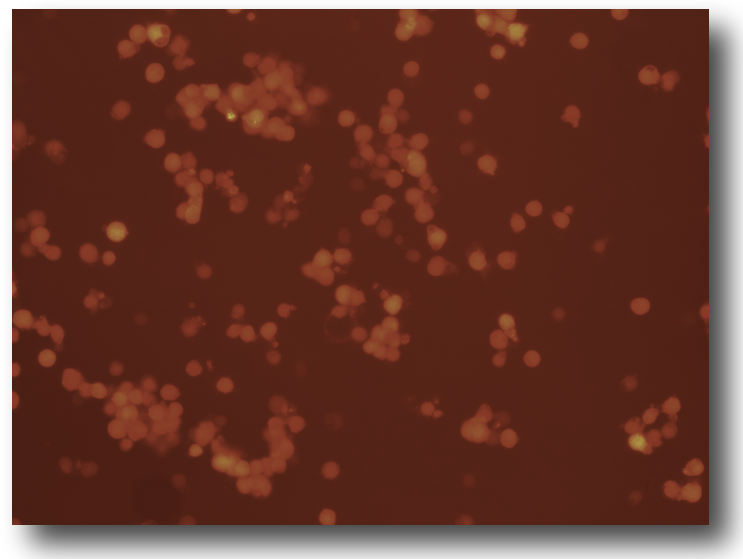

Figura 2. Homogeneidad de la expresión transgénica de la línea celular XXL-GFP. a) Línea celular XXL-GFP infectada con AcMNPV-wt observada con luz UV con filtro para la excitación de i) GFP ii) DsRed. b) Línea celular XXL-GFP infectada con AcMNPV-DsRed observada con luz UV con filtro para la excitación i) GFP ii) DsRed.

Luego de verificar la expresión adecuada del gen indicador de la línea celular XXL-GFP, se analizó su utilidad para el monitoreo de infecciones revelando la expresión del gen indicador con un transiluminador convencional, teniendo en cuenta que no todos los laboratorios de biología molecular disponen de un microscopio de fluorescencia.

Los resultados obtenidos demuestran que el revelado con transiluminador permite diferenciar claramente las células infectadas, tanto en ensayos de dilución terminal como en plaqueos (Figura 4.5). 


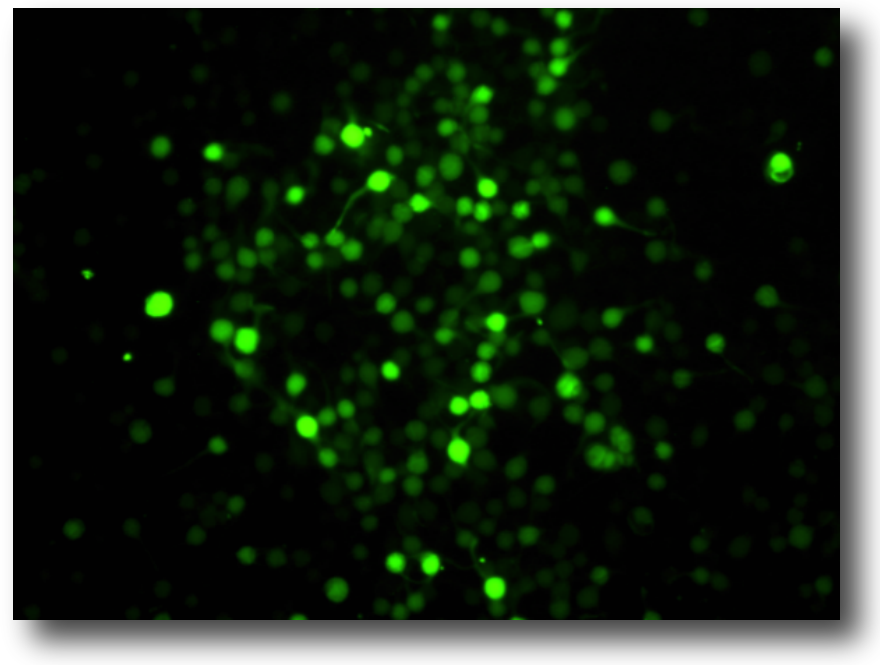

Figura 4.3: Línea celular XXL-GFP infectada con AgMNPV. La expresión de GFP indica que el promotor de poliedrina de AcMNPV es reconocido por los factores transcripcionales codificados por AgMNPV.

\subsection{Discusión}

Se desarrolló una línea celular transgénica que contiene un gen indicador que se activa al infectar con varias especies de baculovirus. Este aspecto es muy útil para la manipulación de los baculovirus en cultivo celular, ya que permite el seguir el desarrollo de la infección virar por métodos no invasivos. Se ha demostrado la estabilidad de la línea celular a largo plazo sin la necesidad de manener la presión de selección del antibiótico.

Se comprobó que la detección de GFP se puede llevar a cabo con un transiluminador convencional, lo que elimina la necesidad de disponer de un microscopio de fluorescencia y los costos que esto implica, surgiendo la posibilidad de utilizar la línea XXL-GFP como medio de monitoreo de rutina.

Se ha destacado que una de las limitantes para la expansión de la aplicación de bioinsecticidas basados en formulaciones de baculovirus consiste en que los métodos de producción actuales se basan en la purificación de poliedros de larvas infectadas. Estos métodos artesanales tienen requerimientos muy altos de mano de obra y su capacidad de producción depende de la disponibilidad de larvas de la especie susceptible. 


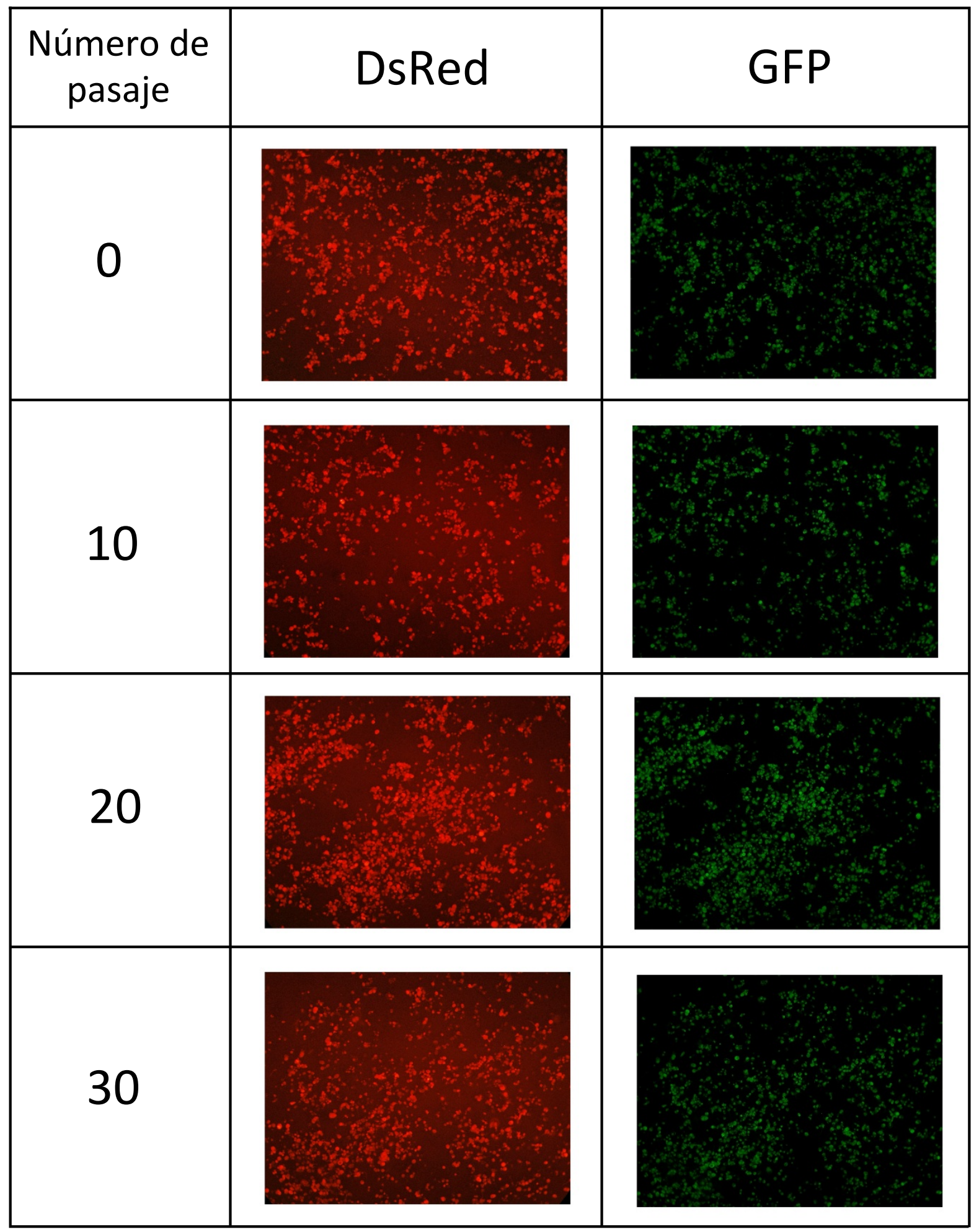

Figura 4.4. Evaluación de la estabilidad genética de la línea XXL-GFP a través de las generaciones. Cada 10 pasajes, se infectaron las células con el virus AcMNPV-DsRed para comparar el patrón de fluorescencia del gen indicador del virus (DsRed) con el del transgén de la línea celular (GFP).

En este marco, se han buscado alternativas para aumentar la factibilidad de la producción de baculovirus en cultivos celulares. Además, en la última década se ha 
aprobado la comercialización de varias vacunas basadas en baculovirus para uso en medicina humana y veterinaria. La producción de estos productos se lleva a cabo en líneas celulares de insecto y requiere de controles de calidad entre los cuales se encuentra el recuento de partículas infectivas viables. Por lo tanto, los resultados obtenidos permiten plantear la posibilidad de adaptar el uso de la línea celular XXL-GFP a la producción industrial de bioinsecticidas y vacunas y otros productos de interés médico e industrial basadas en baculovirus en cultivo celular.

i)

ii)

a
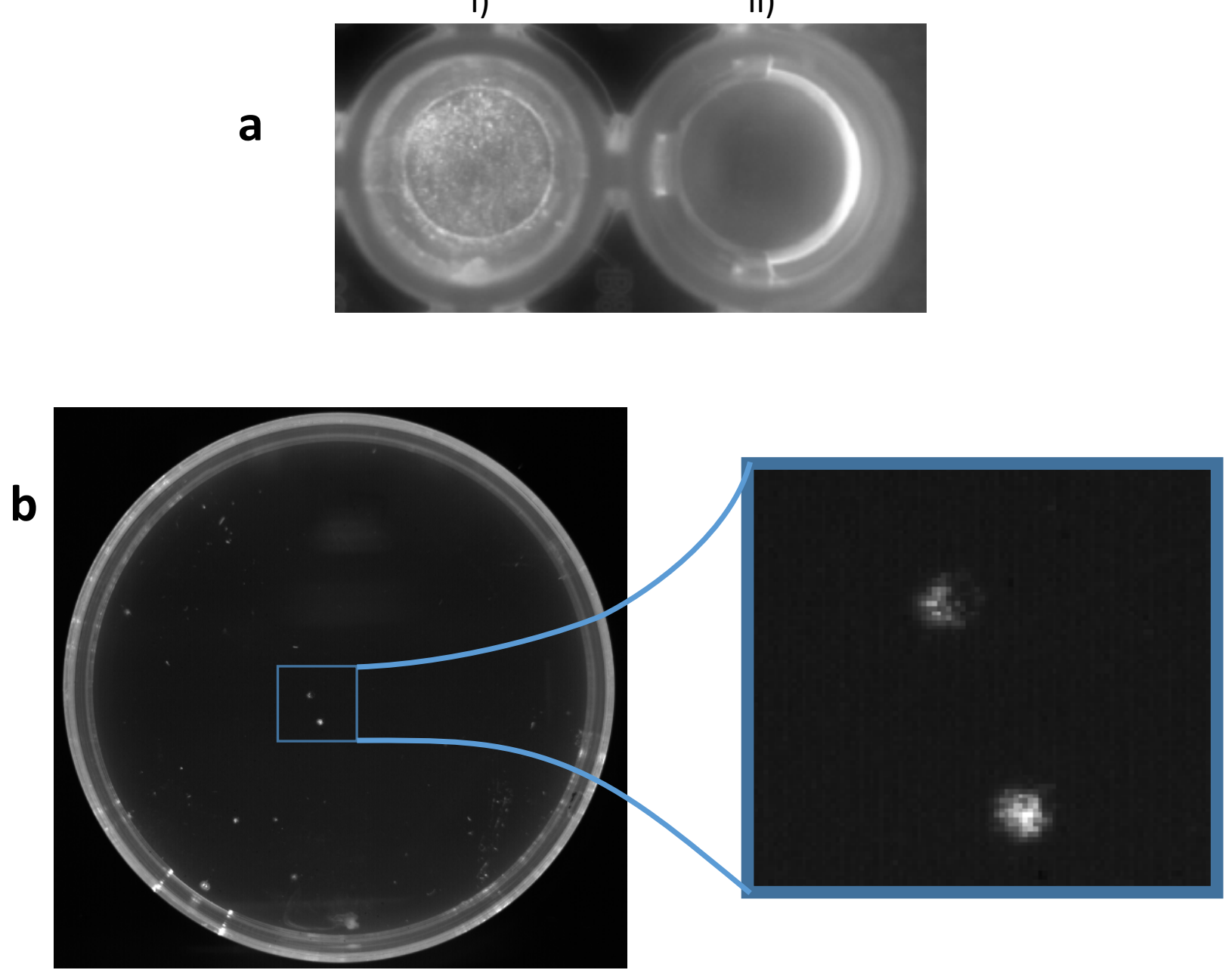

Figura 4.5. a) Pocillos con monocapas de células XXL-GFP i) infectadas con AcMNPV y ii) sin infectar, reveladas con transiluminador UV con filtro de $320 \mathrm{~nm}$. b) Pocillo con monocapa de células XXL-GFP infectadas con AcMNPV en bajo título e inmovilizada con agarosa, revelada con transiluminador UV con filtro de $360 \mathrm{~nm}$ luego de 7 días. Se distinguen placas de infección viral. 


\section{Referencias}

Hopkins, R. y Esposito, D. (2009). A rapid method for titrating baculovirus stocks using the Sf-9 Easy Titer cell line. Biotechniques 47 (3), 785-788.

InsectSelect ${ }^{\mathrm{TM}}$ BSD System, I. (2008). For Stable Expression of Heterologous Proteins in Lepidopteran Insect Cell Lines using pIB/V5-His. Catalog nos. K820-01, K825-01, V8020-01

Lopez, M.G.; Alfonso, V.; Carrillo, E.; Taboga, O. (2010). Trans-complementation of polyhedrin by a stably transformed Sf9 insect cell line allows occ- baculovirus occlusion and larval per os infectivity. J. Biotechnol. 145 (2), 199-205.

Maruniak, J.E.; Garcia-Canedo, A.; Rodrigues, J.J. (1994). Cell lines used for the selection of recombinant baculovirus. In Vitro Cell. Dev. Biol. Anim. 30a (4), 283-286.

O'Reilly, D.R.; Miller, L.K.; Luckow, V.A. (1994). Baculovirus Expression Vectors: A Laboratory Manual. Oxford University Press. 347 páginas.

Wickham, T. J.; Davis, T.; Granados, R.R.; Shuler, M.L.; Wood, H.A. (1992). Screening of insect cell lines for the production of recombinant proteins and infectious virus in the baculovirus expression system. Biotechnol. Prog. 8 (5), 391-396. 



\section{Capítulo 5}

Análisis de la transactivación transcripcional de elementos promotores entre alfa y betabaculovirus. 



\subsection{Introducción}

La "oruga de las leguminosas", Anticarsia gemmatalis, es una de las mayores plagas de la soja y otros cultivos de leguminosas. Para su control se ha utilizado con éxito el virus AgMNPV. Por otra parte, se ha caracterizado un virus de la granulosis de Epinotia aporema (Wals., 1914) (Lepidoptera: Tortricidae), una de las principales plagas de la soja y otras leguminosas de interés agronómico, tales como poroto, maní, lenteja, garbanzo y alfalfa (Goldberg et al., 2002; Sciocco-Cap et al., 2001). Una limitación seria para realizar estudios más detallados a nivel molecular sobre el ciclo de infección es la falta de una línea celular susceptible. Recientemente ha sido determinado el genoma completo de este virus (Ferrelli et al., 2012).

En este contexto, considerando que AgMNPV y EpapGV están siendo evaluados para su uso como agentes de control de los lepidópteros Anticarsia gemmatalis y Epinotia aporema, y que estas plagas se presentan en forma simultánea durante cierta época del año, sería interesante contar con un baculovirus modificado con rango de hospedador ampliado a ambas plagas. Una posible estrategia para desarrollar este baculovirus con rango de hospedador expandido consistiría en generar recombinantes de AgMNPV en células derivadas de $A$. gemmatalis con regiones genómicas relativamente extensas de EpapGV y seleccionarlos por su infectividad sobre E. aporema. Sin embargo, es necesario considerar antes que la expresión de los genes de EpapGV en el entorno heterólogo dependerá de la transactivación de los promotores por parte de la maquinaria transcripcional de la célula y productos génicos de AgMNPV.

Para comenzar a evaluar este problema, se requiere estudiar la regulación transcripcional de genes de EpapGV en el contexto del genoma de AgMNPV y del sistema heterólogo de A. gemmatalis. Cabe mencionar que no se ha llevado a cabo aún un estudio detallado de los niveles de activación de promotores de betabaculovirus por parte de los factores transcripcionales de un alfabaculovirus.

El primer objetivo en el estudio de la transactivación transcripcional de promotores de EpapGV en el entorno de AgMNPV consistió en la selección de promotores y el diseño de primers para su amplificación y clonado. Se decidió evaluar la transactivación promotores de genes correspondientes a diferentes fases del ciclo de vida del virus: un gen temprano 
inmediato, ie-1, un gen temprano retrasado, egt y un gen de la fase muy tardía, poliedrina o granulina.

Para el análisis se desarrollaron cultivos celulares establemente transformados con construcciones indicadoras cuya expresión se encuentra bajo el control transcripcional de las regiones regulatorias seleccionadas. Por un lado, este sistema permite independizar el experimento de la eficiencia de transfección, ya que se eliminan las células que no incorporan el plásmido en el genoma por su sensibilidad al antibiótico. Por otra parte, se ha informado que la activación de los promotores de los genes tardíos de los baculovirus requiere de la replicación del DNA (Rice y Miller, 1986), por lo cual es posible que un experimento de expresión transitoria con vectores plasmídicos (que no replican en células de insecto) arroje resultados negativos.

\subsection{Materiales y Métodos.}

\subsubsection{Generación de plásmidos con un gen indicador bajo el control de promotores de} AgMNPV y EpapGV.

Se amplificaron por PCR los promotores seleccionados utilizando los primers detallados en la tabla 5.1 sobre los moldes de DNA genómico de AgMNPV y EpapGV. Los productos de PCR obtenidos se clonaron independientemente en el vector pGEM-T Easy. Seguidamente, se digirió con Notl y desfosforiló el vector de selección pIB/V5-His y en él se subclonaron independientemente los promotores liberados de pGEM-T Easy con la misma enzima de restricción. De esta manera, se generaron seis plásmidos con cada uno de los promotores seleccionados y un marcador de selección para la integración del DNA foráneo en las células de insecto (resistencia a blasticidina). Finalmente, en cada uno de estos plásmidos se introdujo el ORF de GFP, para ubicarlo bajo el control del promotor viral. El ORF se liberó del vector pXXL-GFP (capítulo 3) con Xbal y se clonó en el mismo sitio del vector plB-promotor.

\subsubsection{Producción de cultivos celulares transgénicos}

Se transfectaron células High Five ${ }^{\mathrm{TM}}$ con las construcciones indicadoras con cada uno de los promotores analizados. Se utilizó el reactivo de transfección Cellfectin II (Invitrogen ${ }^{\circledR}$ ), transfectando $2 \mu \mathrm{g}$ de DNA plasmídico en cada caso y siguiendo las 
instrucciones del fabricante (ver Anexo). Para la selección de células transgénicas, dos días después de la transfección se agregó blasticidina a una concentración de $40 \mu \mathrm{g} / \mathrm{ml}$ final en cada pocillo.

\begin{tabular}{|l|l|l|}
\hline PCR & Primer & Secuencia $\left(5^{\prime}\right.$ - 3') $^{\prime}$ \\
\hline pie1 AgMNPV & Pie1Ag/Pstl & TATAAGATCTGCAGGTACAATTG \\
\hline & pie1Agrev & CATGAAGATCTATTTATACC \\
\hline pie1 EpapGV & Pie1Epap-Up & CATCAAGCTTCCCGCATCAC \\
\hline pegt AgMNPV & PieEpap-Down & CACACTCCATAAGCTTTGTCTG \\
\hline & PegtAg600-Up & CCTCTAAGCTTTTCGTCTATGTACATGTT \\
\hline pegt EpapGV & PegtAg600-Down & ATAAAAAGCTTCGTAAATGCAGTTCAAT \\
\hline & PegtEP-Up & TCGTCCAAGCTTTGCGCACCTATCAGCT \\
\hline ppolh AgMNPV & PegtEp-Down & GTCCACAAGCTTACTGATGTTGGAG \\
\hline & PpolhAg600-Up & TGTACAAAGCTTCTAATTGCGTAAAAATG \\
\hline pgra EpapGV & PgraEp-Up & TAATCAAGCTTAGTTATAGCAAATTTTA \\
\hline & PgraEp-Down & AAATAATGAAGCTTAAGCATGTGGA \\
\hline
\end{tabular}

Tabla 5.1: Primers utilizados para desarrollar cada una de las construcciones indicadoras.

\subsubsection{Evaluación de la transactivación transcripcional de los promotores en las células transgénicas}

Para evaluar la activación transcripcional de las construcciones incorporadas en las células transgénicas, se infectaron los cultivos con AgMNPV-wt a una MOI de 10 (Richardson et al., 2007). A diferentes tiempos post-infección se observó la expresión de GFP por microscopía de fluorescencia.

\subsection{Resultados}

Para el análisis de la transactivación transcripcional de promotores de betabaculovirus y alfabaculovirus seleccionados, se desarrollaron construcciones indicadoras que contienen promotores seleccionados de tres etapas del ciclo replicativo del baculovirus. Se seleccionaron: el promotor ie-1, de la etapa inmediata temprana (se sabe que no requiere factores virales para su activación (Guarino y Summers, 1986; Rohrmann, 2013), el promotor del gen egt, de la etapa temprana retrasada y el promotor de la proteína 
mayoritaria del cuerpo de oclusión, poliedrina (polh) o granulina ( $g r a)$, de la etapa muy tardía del ciclo replicativo.

En la primera etapa se amplificaron por PCR regiones de 600 nucleótidos upstream al inicio del marco de lectura de estos genes para las especies AgMNPV y EpapGV. En el caso del promotor de ie-1 de AgMNPV, la región amplificada fue de unos 423 nucleótidos, debido a que ya se informó que esta secuencia era suficiente para activar la expresión de un gen indicador (Bilen et al., 2007) (Figura 5.1).

Se transfectaron células High Five ${ }^{\mathrm{TM}}$ con cada una de las construcciones y se seleccionaron aquellas células que integraron los plásmidos en el genoma con el agregado de blasticidina. Posteriormente, los cultivos transgénicos fueron infectados para evaluar la activación de los promotores.

Como era esperable, las células transformadas con las construcciones indicadoras que contienen promotores tempranos inmediatos (pie-1 de AgMNPV y pie-1 de EpapGV) evidenciaron expresión de GFP sin necesidad de infección. Esto se atribuye a que los promotores de ie-1 no requieren de factores transcripcionales codificados por el virus, por lo que su actividad no depende de la infección viral (Blissard, Kogan, Wei, \& Rohrmann, 1992). No se observó diferencia entre células no infectadas e infectadas 24 horas post infección (hpi) (Figura 5.2).

Los promotores tempranos retrasados (pegtAgMNPV y pegtEpapGV) y muy tardíos (ppolhAgMNPV y pgraEpapGV), por otra parte, no mostraron transcripción en células no infectadas. En las células transgénicas con construcciones indicadoras con todos estos promotores, se observó expresión de GFP al infectar con AgMNPV. No se realizaron infecciones con EpapGV ya que no existen líneas celulares susceptibles a este virus.

En el caso de los promotores tempranos retrasados, se observó que se alcanzan niveles altos de expresión con sólo 24 hpi y después de ese tiempo estos se mantienen estables hasta las 96 hpi (Figura 5.3). En el caso de los promotores muy tardíos, la expresión va aumentando y llega a un nivel comparable al de los promotores tempranos retrasados luego de las 72 hpi (Figura 5.4). 


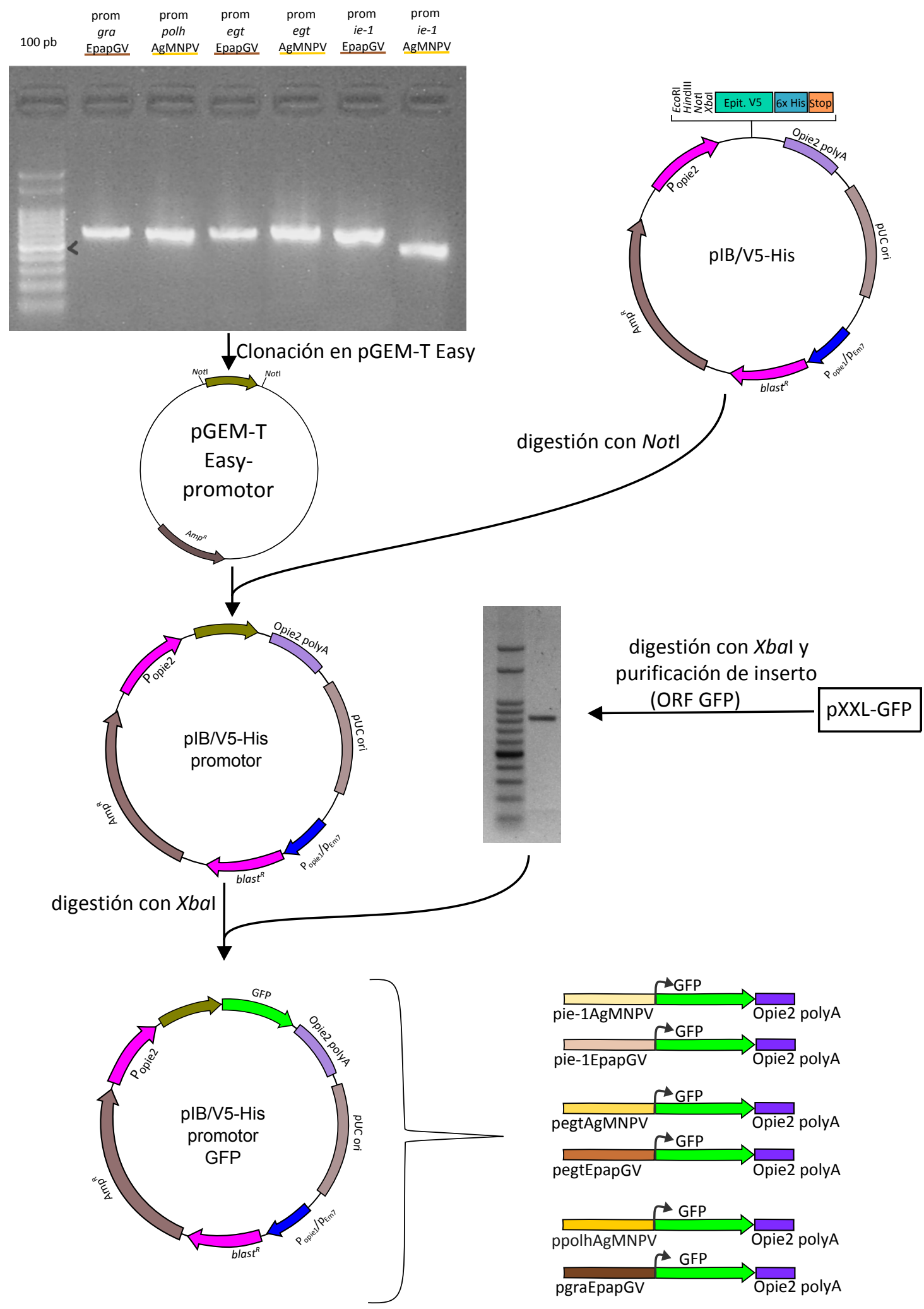

Figura 5.1. Esquema del desarrollo de las construcciones indicadoras empleadas. En la primera etapa, se amplificaron por PCR los promotores de AgMNPV y EpapGV y se clonaron en el vector pGEM-T Easy. Luego, cada promotor fue liberado del vector pGEM-T Easy con Notl y clonado en el vector pIB/V5-His. Finalmente, cada plásmido pIB/V5conteniendo un promotor diferente fue digerido con Xbal y se clonó en este sitio el ORF de GFP liberado del vector PXXL-GFP. 


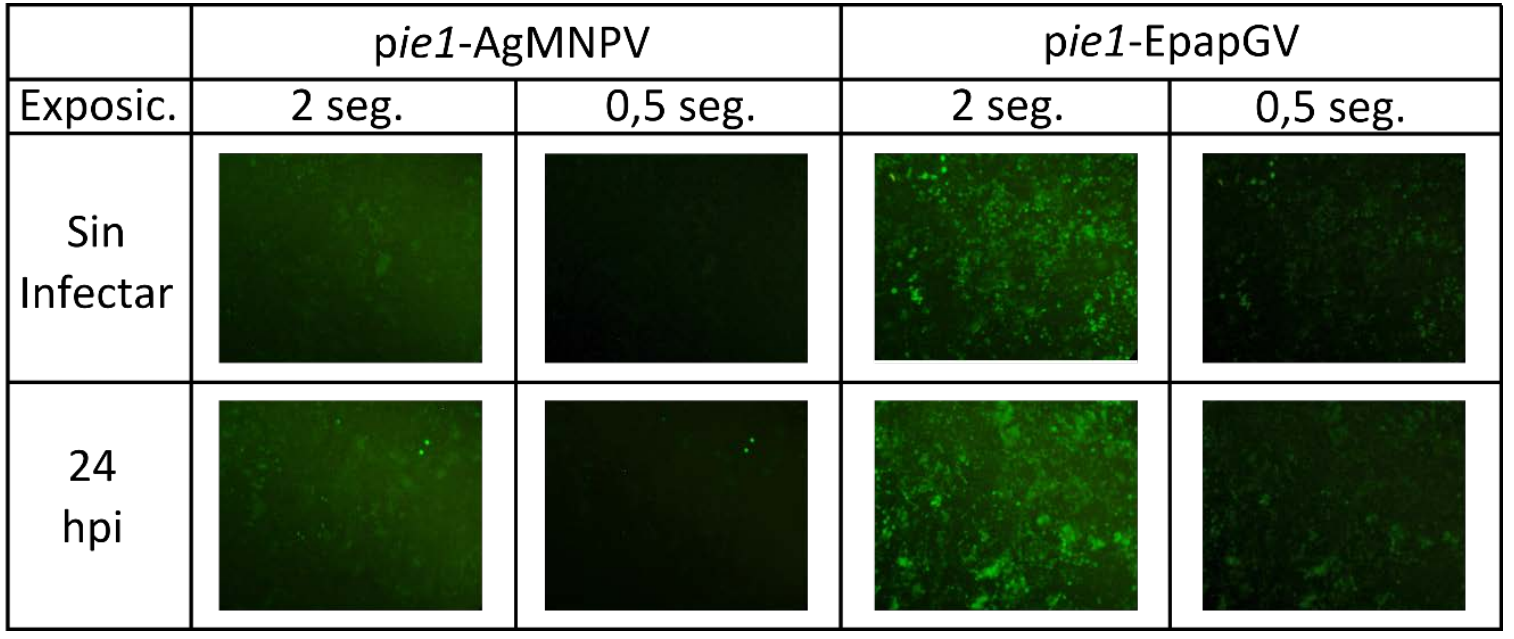

Figura 5.2. Actividad de los promotores tempranos inmediatos (ie-1) de AgMNPV y EpapGV en células transformadas sin infectar e infectadas con AgMNPV-wt a diferentes tiempos.

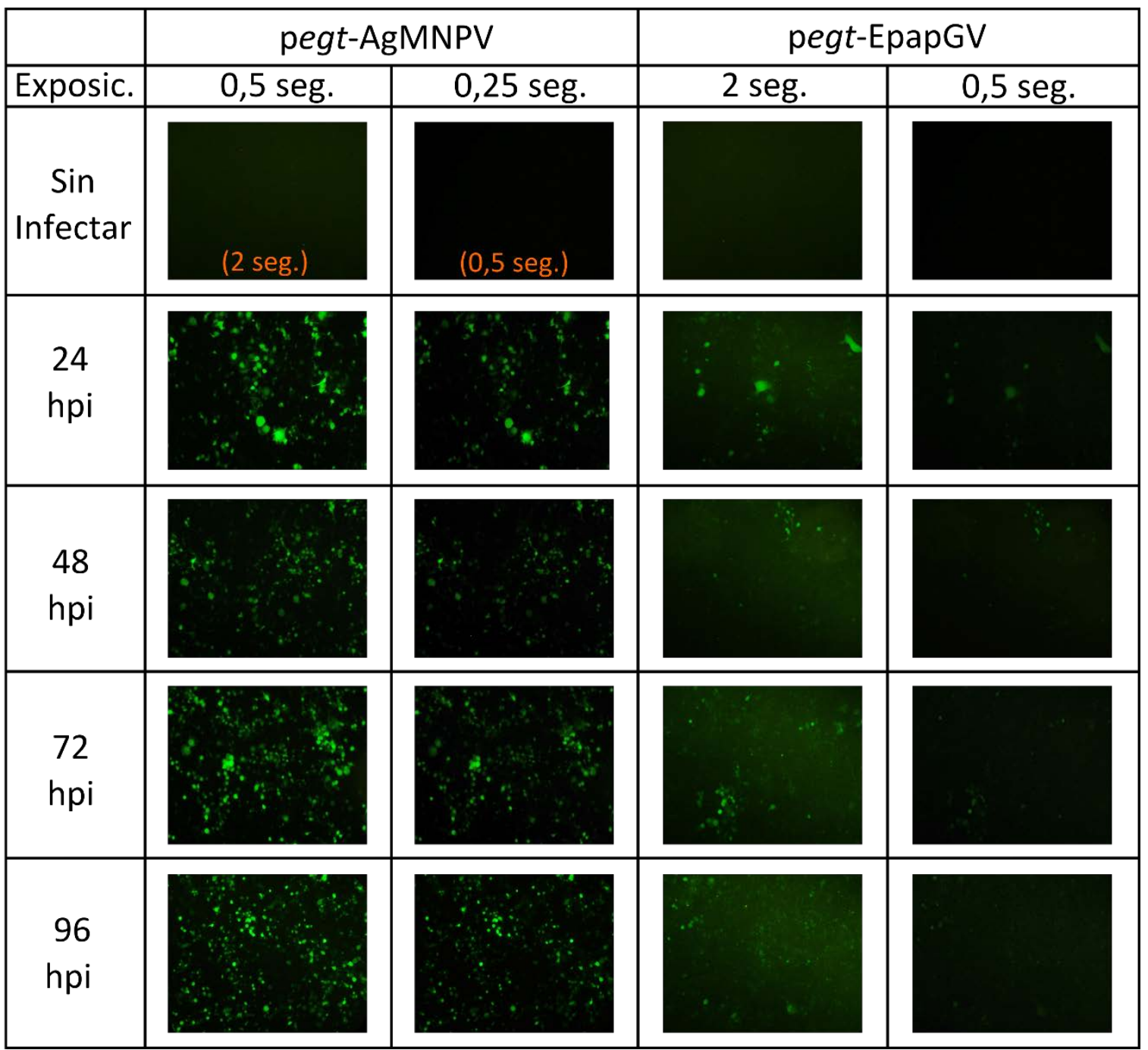

Figura 5.3. Actividad de los promotores tempranos retrasados (egt) de AgMNPV y EpapGV en células transformadas sin infectar e infectadas con AgMNPV-wt a diferentes tiempos. En el caso del promotor de egt de AgMNPV se utilizó un menor tiempo de exposición en la adquisición de la imagen comparado con el promotor de EpapGV, excepto en los cultivos no infectados. 
Tanto en los promotores tempranos retrasados como en los muy tardíos, se observó una diferencia importante entre los niveles de expresión de los elementos de AgMNPV y EpapGV. Esto puede deberse a un reconocimiento bajo de las secuencias promotoras de EpapGV por parte de los factores transcripcionales de AgMNPV.

\begin{tabular}{|c|c|c|c|c|}
\hline & \multicolumn{2}{|c|}{ ppolh-AgMNPV } & \multicolumn{2}{|c|}{ pgra-EpapGV } \\
\hline Exposic. & 2 seg. & $0,5 \mathrm{seg}$. & 2 seg. & $0,5 \mathrm{seg}$. \\
\hline $\begin{array}{c}\text { Sin } \\
\text { Infectar }\end{array}$ & & & & \\
\hline $\begin{array}{c}24 \\
\text { hpi }\end{array}$ & & & & \\
\hline $\begin{array}{l}48 \\
\text { hpi }\end{array}$ & & & & \\
\hline $\begin{array}{l}72 \\
\text { hpi }\end{array}$ & & & & \\
\hline $\begin{array}{r}96 \\
\text { hpi }\end{array}$ & & & & \\
\hline
\end{tabular}

Figura 5.4. Actividad de los promotores muy tardíos (ppolh de AgMNPV y pgra de EpapGV) en células transformadas sin infectar e infectadas con AgMNPV-wt a diferentes tiempos.

\subsection{Discusión}

Se estudió la transactivación transcripcional de elementos regulatorios entre dos géneros de baculovirus: Alfabaculovirus y Betabaculovirus. Para el análisis se seleccionó como sistema experimental la transformación estable de células con construcciones indicadoras y la infección con baculovirus para la inducción de los promotores. 
Los resultados obtenidos indican que los promotores de EpapGV seleccionados son reconocidos y activados por los factores transcripcionales codificados por AgMNPV. En el caso de los promotores tempranos inmediatos, la expresión del promotor de EpapGV resultó mayor a la del de AgMNPV. Esto podría deberse a que la secuencia clonada de EpapGV contiene unos 200 nucleótidos adicionales (upstream) comparada con la de AgMNPV y podrían existir secuencias importantes para la transcripción en esta región.

Por otro lado, los niveles de expresión de los promotores tempranos retrasados y muy tardíos de EpapGV fueron muy bajos comparados con los promotores autólogos (de AgMNPV) correspondientes.

Este resultado implica que la construcción de baculovirus híbridos entre alfabaculovirus y betabaculovirus con fragmentos genómicos heterólogos relativamente grandes como una estrategia para modificar el rango de hospedador es factible siempre que los niveles de expresión de los genes heterólogos sean suficientes.

El desarrollo de estos baculovirus recombinantes híbridos puede ser utilizado para verificar los resultados obtenidos en el contexto de la infección de una, a través de estudios de expresión de los genes heterólogos insertados en el genoma del virus recombinante. Además, la generación de estos baculovirus híbridos y la posibilidad de utilizarlos para infecciones en forma combinada permitirá evaluar una alternativa empírica para la modificación del rango de hospedador de los baculovirus.

Finalmente, se destaca que se consiguió un nivel de expresión elevado en un corto tiempo (<24 hpi) al evaluar el promotor temprano retrasado de egt. La construcción desarrollada que contiene este promotor se podría utilizar para la generación de líneas celulares que permitirían la titulación rápida de baculovirus y, además este descubrimiento se puede explotar para la expresión de genes tóxicos en baculovirus genéticamente mejorados para su empleo en el control biológico de plagas. 


\section{Referencias}

Bilen, M.F.; Pilloff, M.G.; Belaich, M.N.; Da Ros, V.G.; Rodrigues, J.C.; Ribeiro, B.M.; Romanowski, V.; Lozano, M.E.; Ghiringhelli, P.D. (2007). Functional and structural characterisation of AgMNPV ie1. Virus Genes, 35 (3), 549-562. doi:

Blissard, G.W.; Kogan, P.H.; Wei, R.; Rohrmann, G.F. (1992). A synthetic early promoter from a baculovirus: roles of the TATA box and conserved start site CAGT sequence in basal levels of transcription. Virology, 190 (2), 783-793.

Ferrelli, M.L.; Salvador, R.; Biedma, M.E.; Berretta, M.F.; Haase, S.; Sciocco-Cap, A.; Ghiringhelli, P.D.; Romanowski, V. (2012). Genome of Epinotia aporema granulovirus (EpapGV), a polyorganotropic fast killing betabaculovirus with a novel thymidylate kinase gene. BMC Genomics, 13, 548. doi: 10.1186/1471-216413-548.

Goldberg, A.V.; Romanowski, V.; Federici, B.A.; Sciocco de Cap, A. (2002). Effects of the Epap granulovirus on its host, Epinotia aporema (Lepidoptera: Tortricidae). J. Invertebr. Pathol., 80 (3), 148-159.

Guarino, L.A., Summers, M.D. (1986). Functional mapping of a trans-activating gene required for expression of a baculovirus delayed-early gene. J. Virol., 57 (2), 563-571.

Rice, W.C. y Miller, L.K. (1986). Baculovirus transcription in the presence of inhibitors and in nonpermissive Drosophila cells. Virus Res., 6 (2), 155-172.

Rohrmann, G.F. (2013). Baculovirus Molecular Biology, Third Edition. Bethesda (MD): National Center for Biotechnology Information (US); 2013. Available from: http://www.ncbi.nlm.nih.gov/books/NBK114593/.

Sciocco-Cap, A.; Parola, A.D.; Goldberg, A.V.; Ghiringhelli, P.D.; Romanowski, V. (2001). Characterization of a granulovirus isolated from Epinotia aporema Wals. (Lepidoptera: Tortricidae) larvae. Appl. Environ. Microbiol., 67 (8), 3702-3706. doi: 10.1128/aem.67.8.3702-3706.2001 



\section{Capítulo 6}

Desarrollo de un sistema de recombinación de alta eficiencia para AgMNPV y descubrimientos sobre el gen esencial 1629 



\subsection{Introducción}

El virus de la poliedrosis múltiple de Anticarsia gemmatalis (AgMNPV) ha sido utilizado para el control de la oruga de las leguminosas, una plaga clave de la soja (Moscardi, 1999). Sin embargo, su velocidad de acción relativamente lenta en climas más templados limita su aplicación en nuestro país.

Para resolver esta limitación, se ha planteado la posibilidad de introducir modificaciones en su genoma, para lo cual se recurre en general a la recombinación homóloga entre el baculovirus y un vector de transferencia. Como la frecuencia de la recombinación homóloga es baja, se han desarrollado estrategias que permiten aumentar la frecuencia de progenie recombinante (Haase et al., 2013).

Recientemente, en nuestro laboratorio se han desarrollado y evaluado estrategias para la generación de AgMNPV recombinantes sobre la base de la linealización de un genoma viral deficiente en el gen de poliedrina y el uso de vectores de transferencia plasmídicos que permiten la recuperación del fenotipo $\mathrm{pol}^{+}$(infectivo por vía oral en la naturaleza) (Ver capítulo 2). Este desarrollo ha permitido la obtención y purificación de un virus de AgMNPV que expresa la proteína verde fluorescente (GFP) bajo el control del promotor de poliedrina. Sin embargo, el aislamiento de este virus ha requerido de sucesivos aislamientos por placa con el fin de eliminar la contaminación del genoma parental y los productos de una recombinación homóloga simple o ilegítima. Cabe mencionar que, a pesar de asegurar una digestión completa del genoma parental, los eventos de reparación celular pueden dar lugar a la generación de un virus reparado (circular) que no es producto de la recombinación con el vector de transferencia. Si bien la posibilidad de uso de un genoma parental linealizable disminuye en forma muy significativa la recuperación de virus no recombinantes, ésta no se elimina totalmente. Por lo tanto, la necesidad de un aislamiento clonal es inevitable en este sistema de recombinación. La clonación por repetidos aislamientos de placas demanda mucho tiempo y esto limita las posibilidades de generar diferentes variantes de virus recombinantes.

Entre las estrategias que han sido evaluadas para disminuir la contaminación (background) en el proceso de generación de recombinantes, una de las más exitosas 
ha sido la generación de baculovirus defectivos en un gen esencial. Estos virus no son viables en cultivo celular, por lo tanto se requiere la introducción de un origen de replicación heterólogo en su DNA genómico para mantenerlos como cromosomas artificiales en bacterias (bácmidos) o en levaduras. De esta forma, su replicación ocurre sin necesidad de establecer un ciclo infectivo y se puede extraer fácilmente DNA genómico viral a partir de estos microorganismos. El DNA extraído es transfectado en cultivo celular en conjunto con un vector de transferencia que permite restituir el gen esencial y la incorporación de uno o varios genes que se desean expresar en el baculovirus. El virus parental no es viable y sólo la recombinación homóloga permite la generación de un genoma viable, por lo tanto en estos casos los porcentajes de viriones con DNA parental que pueden aparecer en la progenie de las células cotransfectadas son mínimos y la tarea de purificar un clon recombinante se ve facilitada.

Se consideró la posibilidad de generar un baculovirus AgMNPV deficiente en un gen esencial para utilizarlo como genoma parental en un sistema de recombinación de alta eficiencia. El mantenimiento de baculovirus deficientes en genes esenciales se ha llevado a cabo siempre a través de la generación de bácmidos, aunque la construcción de estos genomas recombinantes requiere de la introducción de secuencias heterólogas extensas que contengan elementos de replicación y genes de selección bacterianos. La generación de bácmidos resulta un trabajo dificultoso y por esta razón sólo se ha conseguido completar el desarrollo para unas pocas especies de baculovirus modelo (AcMNPV (Luckow et al., 1993), virus de la poliedrosis simple de Helicoverpa armigera (Hou et al., 2002; Wang et al., 2003), virus de la poliedrosis múltiple de Spodoptera exigua (Pijlman et al., 2002), virus de la poliedrosis múltiple de Bombyx mori MNPV (Motohashi et al., 2005) y virus de la granulosis de Cydia pomonella (CpGV) (Hilton et al., 2008)). Frecuentemente, en la producción de bácmidos se ha observado la generación de genomas aberrantes (Pijlmann et al., 2002).

Como una alternativa, se este trabajo se propone generar una línea celular que exprese un gen esencial (gen 1629) de AgMNPV con el fin de utilizarla para el mantenimiento por complementación de un genoma de AgMNPV deficiente en este gen. En el desarrollo de este trabajo de tesis, se ha demostrado la complementación funcional de genes de baculovirus mediante el aprovechamiento de cultivos transgénicos (ver Capítulo 3). La 
producción de líneas celulares que expresen un gen esencial del baculovirus permitiría la replicación de un genoma viral deficiente en y la generación de viriones brotantes. Estos viriones con genomas deficientes podrían utilizarse para transducir células transfectadas con un plásmido de transferencia y dar lugar a la generación de recombinantes de segunda generación. Esto representa una ventaja ya que se evitaría la etapa de transfección del genoma parental (de baja eficiencia), sustituyéndola por una etapa de transducción.

En este desarrollo se aprovechará el plásmido pl3 construido previamente (ver capítulo 2) que posee en la región de recombinación downstream parte del ORF de 1629 (un gen esencial) $y$, por lo tanto, puede ser utilizado para rescatar el genoma deficiente mediante recombinación homóloga (Figura 6.1). De esta manera, no se requiere la construcción de un nuevo vector de transferencia.
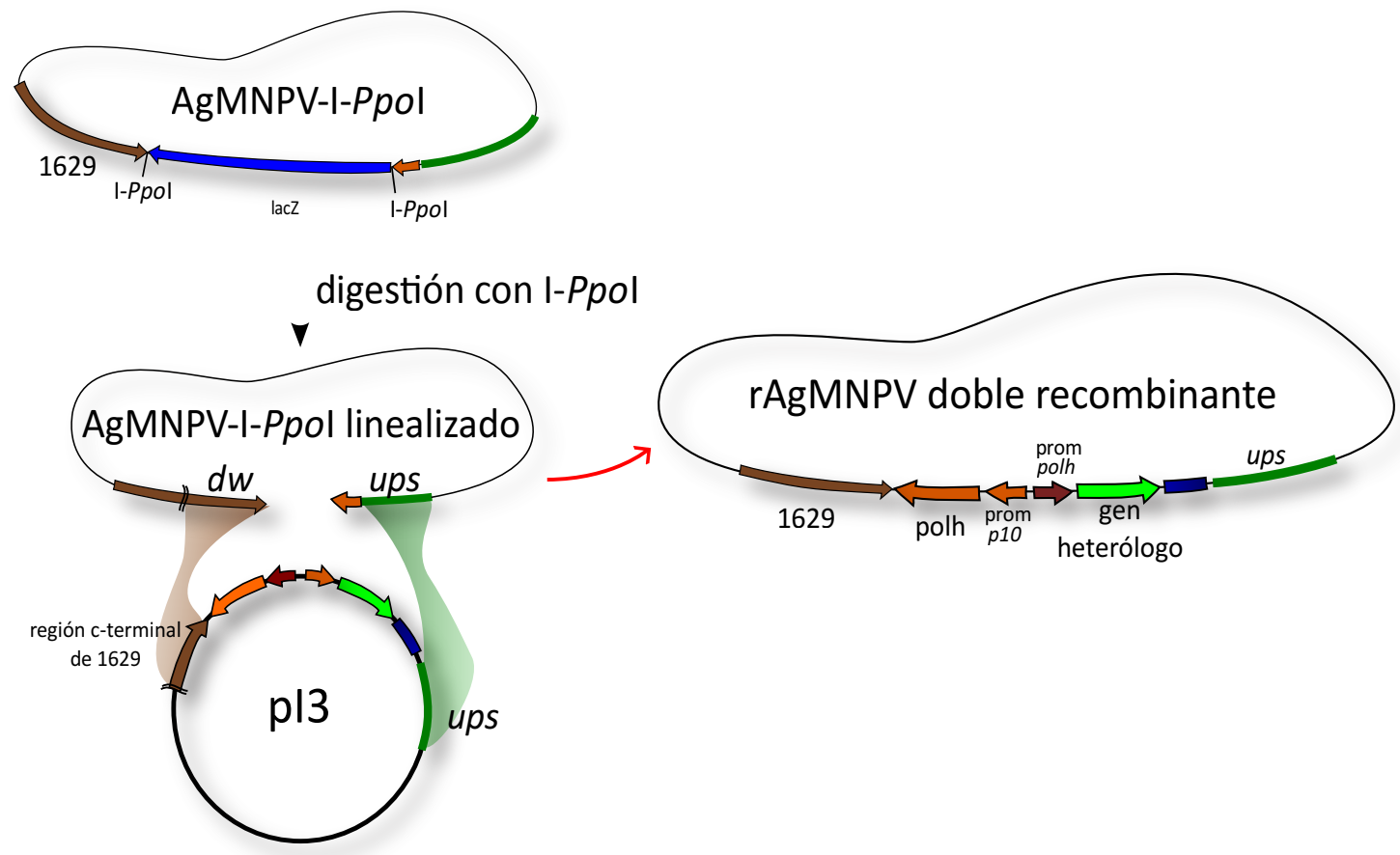

Figura 6.1. Sistema de recombinación desarrollado en base a la linealización del virus parental AgMNPVI-Ppol descripto en el capítulo 1. Se destaca la participación del fragmento c-terminal del marco de lectura del gen 1629 en la recombinación entre el virus parental y el vector de transferencia. La participación de este gen en la recombinación fue aprovechada para el diseño de un sistema de recombinación más eficiente.

Dado que al inicio de este desarrollo no se dispone del AgMNPV con la deleción letal, se utilizará en su lugar un bácmido de AcMNPV defectivo en el gen 1629, denominado bApGOZA (Je, Chang, Choi, et al., 2001; Je, Chang, Roh, \& Jin, 2001). Esto permitirá 
evaluar la línea celular transgénica en forma inmediata e independiente de la construcción del genoma modificado de AgMNPV.

\subsection{Materiales y métodos}

\subsubsection{Clonado del gen 1629 de AgMNPV}

Se amplificó por PCR el ORF del gen 1629 utilizando como molde el DNA genómico del aislamiento AgMNPV-2D (wt), utilizando los primers detallados en la Tabla 1. El producto de amplificación se purificó y clonó en el vector comercial pGEM-T Easy. Luego se subclonó el marco de lectura en un vector comercial para la selección de cultivos celulares de insecto transformados (pIB/V5-His, Invitrogen ${ }^{\circledast}$ ). Este vector permite la expresión del gen heterólogo bajo el control del promotor viral temprano constitutivo del gen ie-1 (immediate early 1) de Orgia pseudotsugata MNPV (OpMNPV) y posee un gen que confiere resistencia a blasticidina para la selección de células transformadas.

\subsubsection{Generación de una línea celular transgénica que expresa constitutivamente el gen 1629 de AgMNPV}

Se transformó mediante transfección mediada por lípidos catiónicos (Cellfectin II, Invitrogen ${ }^{\circledR}$ ) la construcción pIB-1629AgMNPV en la línea celular de insecto High Five ${ }^{\mathrm{TM}}$, siguiendo las recomendaciones del fabricante.

Posteriormente, se procedió al aislamiento de una línea celular monoclonal que exprese de manera estable la proteína 1629 mediante un protocolo de aislamiento clonal por dilución terminal (ver Anexo) (InsectSelect ${ }^{\mathrm{TM}}$ BSD System, 2008).

\subsubsection{Evaluación de la complementación heteróloga de un AcMNPV deficiente en el} gen 1629

Para evaluar la expresión de la proteína heteróloga de la línea transgénica y su capacidad de complementar un baculovirus deficiente, se infectó la líneas transgénica obtenida con el bácmido bApGOZA (Je et al., 2001a,2001b). La complementación del gen se evidenció por la presencia de cuerpos de inclusión en los núcleos de las células. Como control negativo, se transfectaron células High Five ${ }^{\mathrm{TM}}$ con el mismo bácmido. 


\subsubsection{Confirmación de estructura genética de bApGOZA por PCR}

Considerando los resultados obtenidos, se realizó una serie de ensayos de PCR para determinar la ausencia de un fragmento del ORF 1629 en el bácmido bApGOZA. Se diseñaron primers para amplificar fragmentos pequeños $(<400 \mathrm{pb})$ correspondientes a la región N-teminal, media y C-terminal del ORF de 1629 de AcMNPV. Los primers utilizados se encuentran detallados en la tabla 6.1. Se utilizaron como moldes los genomas de AcMNPV-wt y bApGOZA.

\begin{tabular}{|l|l|l|c|}
\hline Primer & $\begin{array}{l}\text { Región de hibridación en } \\
\text { el ORF de } 1629\end{array}$ & Secuencia & $\begin{array}{c}\text { Tamaño del } \\
\text { amplicón (pb) }\end{array}$ \\
\hline Nter1629Fw & N-terminal & CTCGCCACTACAATGCTG & \multirow{2}{*}{345} \\
\hline Nter1629Rv & N-terminal & TGTTAGGCACGGGAGAAG & \multirow{2}{*}{391} \\
\hline Mid1629Fw & Media & AATAGTTGAGGTGCCGACTG & \multirow{2}{*}{381} \\
\hline Mid1629Rv & Media & ACCCTCGTCGTTAGAAGTTG & \\
\hline Cter1629Fw & C-terminal & GTACACTAACGACAGTGATG & \multirow{2}{*}{} \\
\cline { 1 - 2 } Cter1629Rv & C-terminal & TAAGCGCTAGATTCTGTGC & \multirow{2}{*}{} \\
\hline
\end{tabular}

Tabla 6.1. Primers utilizados para verificar la deleción de 1629 en el bácmido bApGOZA

\subsubsection{Evaluación de la replicación del virus deficiente en el gen 1629 bApGOZA.}

Considerando los resultados obtenidos al transfectar células High Five ${ }^{\mathrm{TM}}$ con el virus bApGOZA se analizó la capacidad replicativa de los viriones brotantes utilizando la línea celular indicadora XXL-GFP (ver capítulo 4). Se transfectaron células High Five ${ }^{\mathrm{TM}}$ y High Five-1629Ag con DNA del bácmido bApGOZA extraído de bacterias, utilizando el reactivo Cellfectin II (Invitrogen ${ }^{\circledR}$ ) y siguiendo los protocolos establecidos por el fabricante (ver Anexo). Luego de 7 días se analizó la presencia de OB en las células mediante microscopía óptica y se extrajo el sobrenadante de las transfecciones. Estos sobrenadantes se utilizaron para infectar células XXL-GFP. Se efectuaron diluciones con densidades celulares y multiplicidades de infección variables.

\subsubsection{Generación de un vector de transferencia para la deleción del gen 1629 de AgMNPV.}

El vector de transferencia para la deleción del gen 1629 de AgMNPV se generó utilizando como base el vector de transferencia pI3-GFP. La región de recombinación downstream 
de este vector de transferencia posee la región C-terminal del marco de lectura del gen 1629. Parte de esta región fue eliminada amplificando todo el plásmido por PCR con los primers UpromNcol y Dw1629defNcol (Figura 6.2). Se digirió el producto de PCR con Ncol y se ligó. El vector generado se denominó pi3- $\Delta 1629$ GFP.
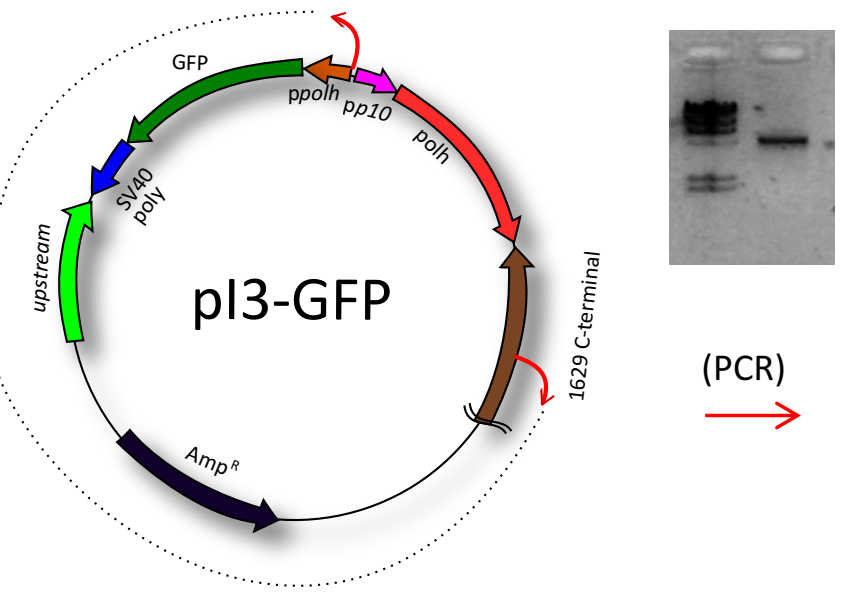

(PCR)
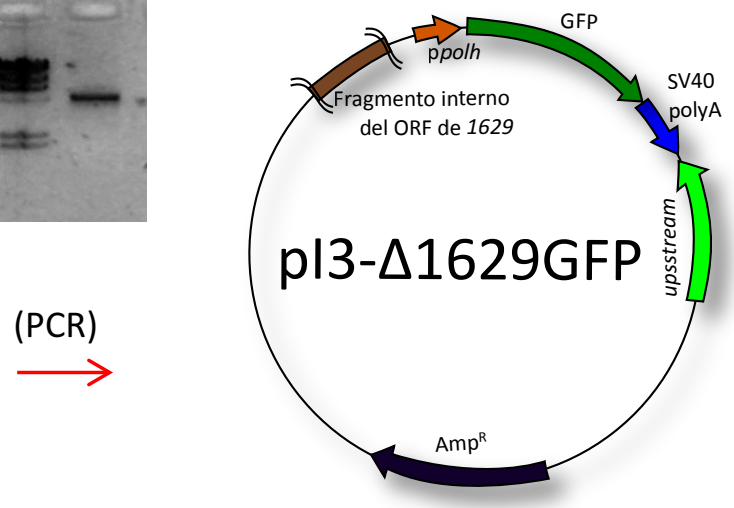

Figura 6.2. Desarrollo del vector de pl3- $1629 \mathrm{GFP}$. Se utilizó como molde el plásmido pl3-GFP (ver Capítulo 1). Se eliminó parte de la región C-terminal del ORF 1629.

\subsection{Resultados}

\subsubsection{Desarrollo de la línea celular transgénica High Five-1629Ag}

Se clonó el marco de lectura del gen 1629 de AgMNPV en un vector que permite la expresión del gen heterólogo bajo el control del promotor viral temprano constitutivo ie-1 (immediate early 1) de Orgia pseudotsugata MNPV (OpMNPV) y posee un gen que confiere resistencia al antibiótico blasticidina para la selección de células transformadas (Figura 6.3). Se transfectaron células High Five ${ }^{\mathrm{TM}}$ con el plásmido obtenido y se generó una línea celular que expresa constitutivamente el gen 1629 de AgMNPV siguiendo el protocolo descripto (ver Anexo). La línea se denominó High Five 1629-Ag.

6.3.2. Complementación funcional de bApGOZA a través de la línea celular High Five-1629Ag y replicación del virus bApGOZA en células que no expresan el gen 1629.

Para analizar si la expresión constitutiva del gen por parte de las línea celular transgénica es capaz de complementar la deficiencia del gen en un baculovirus, se transfectó la línea 
celular con un AcMNPV que posee una deleción en el gen 1629 (Je et al., 2001a, 2001b). La integración del ORF de 1629 en el genoma de la línea celular se comprobó por PCR.
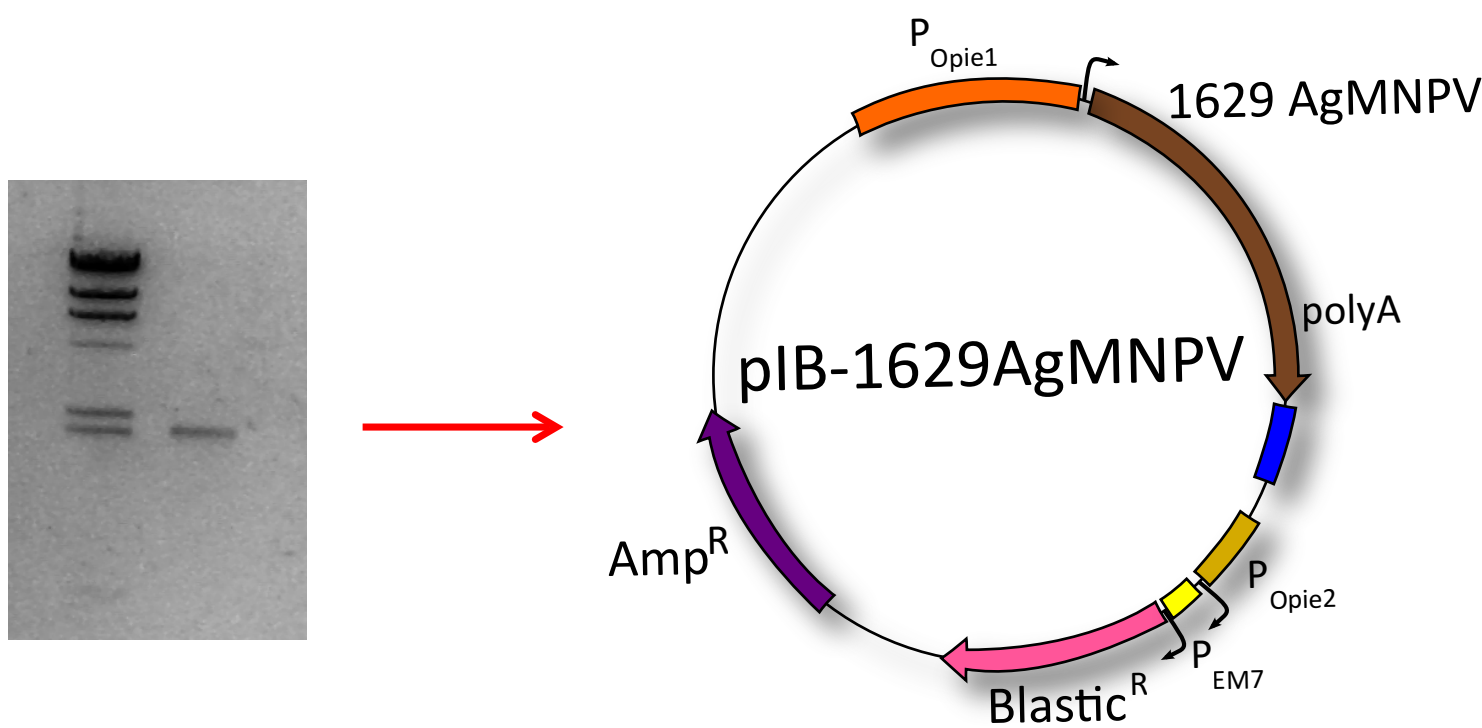

Figura 6.3: a) Producto de PCR del ORF del gen 1629 de AgMNPV. b) Vector de plB-1629AgMNPV. El ORF de 1629 se expresa bajo el control del promotor del gen ie-1 de OpMNPV. El gen de resistencia a blasticidina permite la selección de células de insecto transfectadas en cuyo genoma se encuentra integrado el plásmido.

Se observó la formación de cuerpos de oclusión en los núcleos de las células transfectadas (Figura 6.4), aunque al utilizar como control una transfección de células High Five ${ }^{T M}$ con el virus bApGOZA, se observó que también se forman de cuerpos de oclusión. Eso resultó llamativo porque el gen 1629 es considerado un gen esencial que se ha caracterizado como un gen estructural de la nucleocápside y además se propuso que se encuentra involucrado en la replicación viral (lorio et al., 1998). El descubrimiento de la aparición de cuerpos de oclusión en ausencia del gen 1629 implica, además, que está probablemente está ocurriendo replicación del virus, ya que ésta es necesaria para que tenga lugar la transcripción de poliedrina, un gen con un promotor muy tardío.

Considerando estos resultados llamativos, se decidió confirmar la deleción del gen 1629 en el genoma de bApGOZA. Se diseñaron primers que amplifican las regiones $\mathrm{N}$-terminal (5'), media y C-terminal (3') del ORF de 1629 de AcMNPV. De acuerdo a lo informado en el artículo que describe el desarrollo del bácmido (Je, Chang, Roh, et al., 2001) se eliminó 
por recombinación una parte de la región C-terminal del ORF de 1629. Se utilizó como control el DNA genómico de AcMNPV-wt, que posee el gen 1629 completo. Los resultados confirmaron la ausencia del fragmento C-terminal del gen en bApGOZA (Figura 6.5).

\section{a}

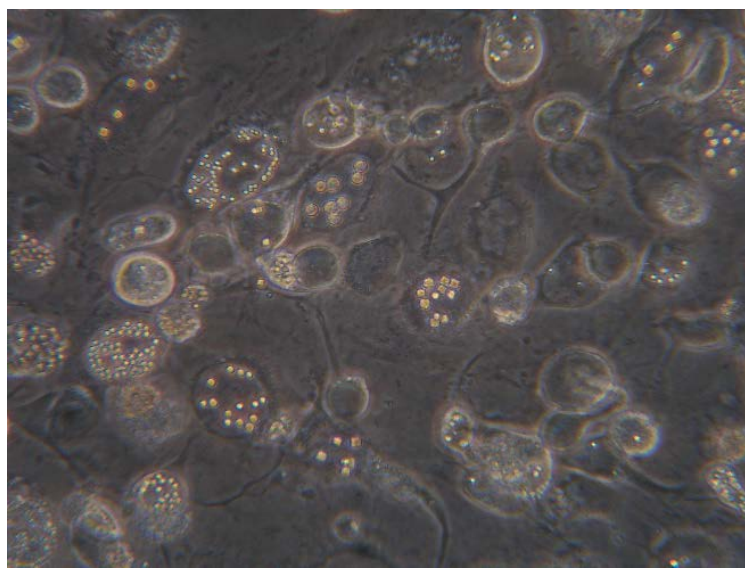

b

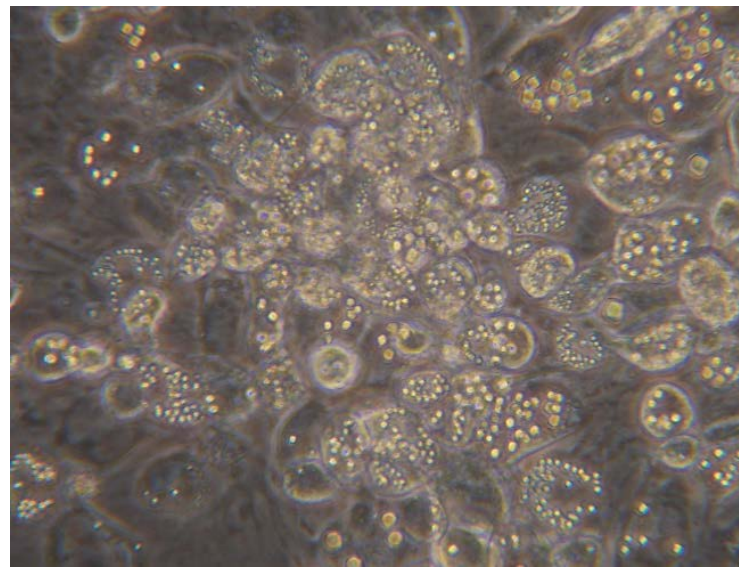

Figura 6.4: a) Células High Five $^{\mathrm{TM}}$ transfectadas con bApGOZA. b) Células High Five-1629Ag transfectadas con bApGOZA.

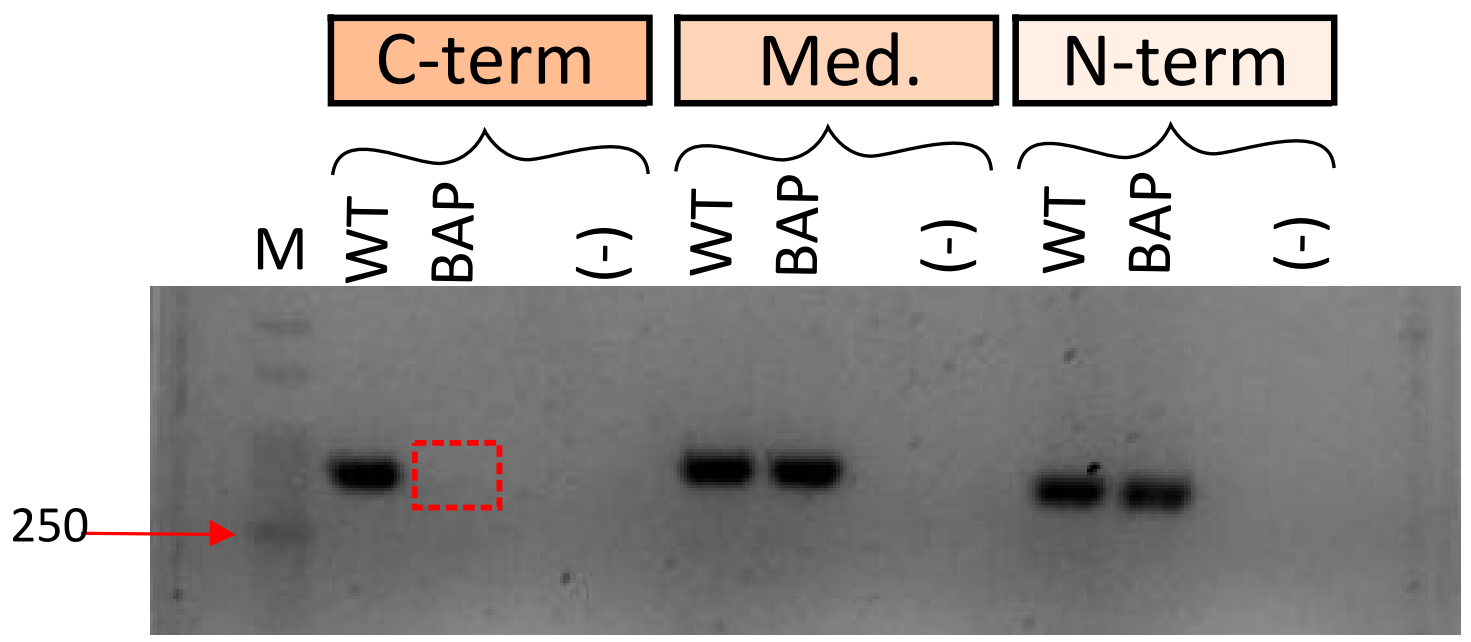

Figura 6.5. PCR de los fragmentos C-terminal, Medio y N-terminal del ORF 1629 de AcMNPV utilizando como moldes el genoma de AcMNPV-wt (WT) y del bácmido bApGOZA (BAP). Se evidencia la ausencia del fragmento C-terminal en el genoma de bApGOZA (recuadro discontinuo en rojo). M: marcador de peso molecular $50 \mathrm{pb}$ (Embiotec) (se destaca la banda de mayor masa de $250 \mathrm{pb}$ ),

Una vez confirmada la deleción del gen 1629 en el genoma de bApGOZA, ante el resultado de la generación de cuerpos de oclusión de este bácmido en células High Five $^{\mathrm{TM}}$ se llevaron a cabo experimentos que permitieran revelar con más detalle qué 
etapas del ciclo infectivo se estaban produciendo en ausencia de 1629 y cuáles se veían limitadas. Se utilizó la línea tituladora XXL-GFP desarrollada previamente (ver capítulo 4) para analizar la formación de virus brotantes y la diseminación del virus deficiente a lo largo del tiempo, de acuerdo al esquema que se detalla en la figura 6.6.

Se recolectaron los sobrenadantes de las células High Five-1629Ag y High Five ${ }^{\mathrm{TM}}$ transfectadas con bApGOZA y se utilizaron para infectar células XXL-GFP (Figura 6.7). Las células XXL-GFP poseen insertado en su genoma el gen indicador GFP bajo el control del promotor de poliedrina de AcMNPV, de forma que la expresión de GFP se activa cuando está ocurriendo replicación de un baculovirus en la célula (ver Capítulo 4). Las infecciones con los sobrenadantes extraídos de High Five ${ }^{\mathrm{TM}}$ no mostraron células fluorescentes, lo que indica que no se formaron virus brotantes en las células transfectadas. En cambio, las infecciones con los sobrenadantes de las células 1629AgMNPV transfectadas se observaron células fluorescentes, como se esperaba.

Esto indica que la complementación del virus bApGOZA con la copia de 1629 de AgMNPV presente en el genoma celular restituye en el virus la capacidad de formar viriones brotantes.

A pesar de la complementación a nivel de proteína, los genomas que contienen los viriones brotantes generados en esta línea celular son idénticos al del virus original (bApGOZA); por lo tanto, son deficientes en el gen 1629. Por esta razón, se esperaba que las células XXL-GFP infectadas evidenciaran fluorescencia pero no fueran capaces de generar nuevos viriones brotantes que dispersaran la infección a otras células. Sin embargo, el monitoreo de la infección de las células XXL-GFP a lo largo de los días indicó que el virus bApGOZA es capaz de dispersarse, dando lugar a la formación de placas de infección (Figura 6.7).

Recurriendo a un análisis de microscopía más minucioso de la dispersión del virus, se observó la aparición repetida de células adyacentes infectadas conectadas por proyecciones citoplasmáticas (filopodios) (Figura 6.8). 

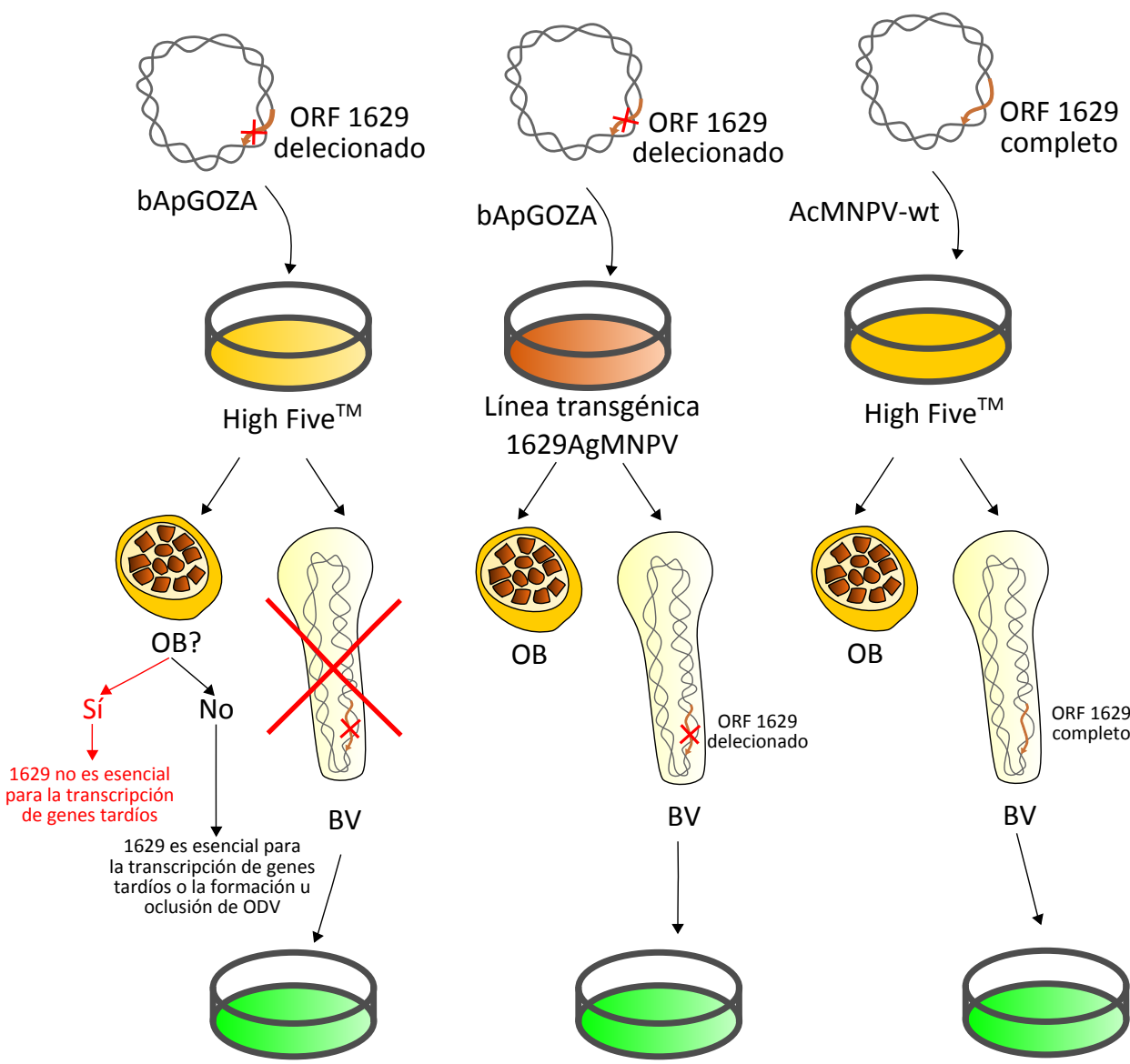

Línea transgénica 1629AgMNPV
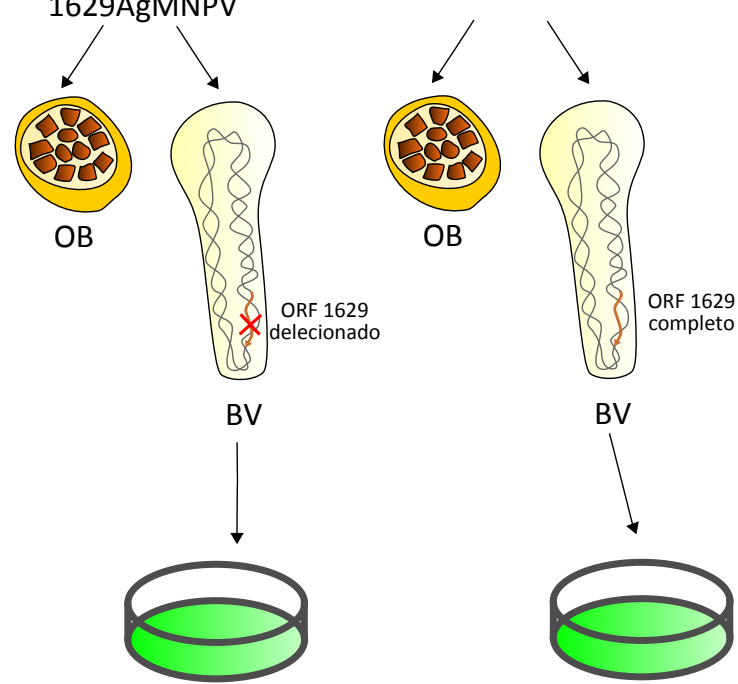

XXL-GFP

XXL-GFP

XXL-GFP
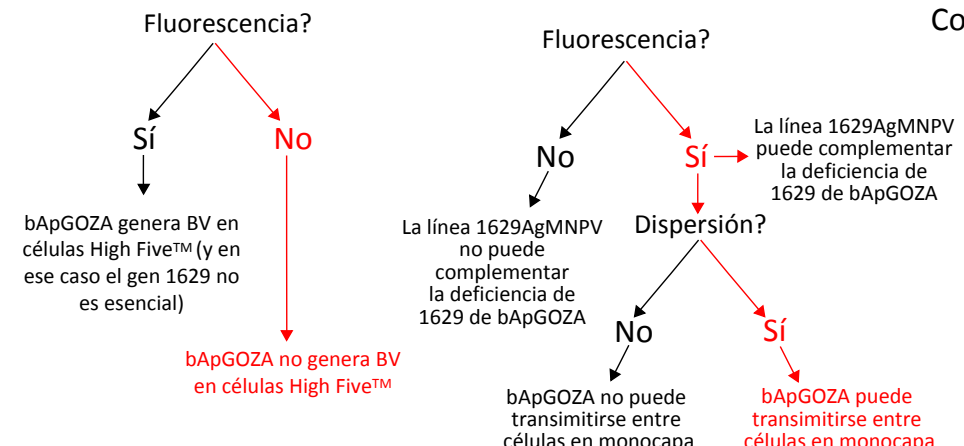

Control positivo de dispersión

Figura 6.6. Representación esquemática de la estrategia experimental diseñada para analizar el rol de 1629 en la infección de células High Five ${ }^{\mathrm{TM}}$. Los experimentos llevados a cabo transfectando el virus bApGOZA en la línea celular High Five $^{\mathrm{TM}}$ y la línea celular transgénica 1629AgMNPV. Los sobrenadantes de estas transfecciones se utilizaron para infectar la línea indicadora XXL-GFP y determinar en qué condiciones se producen virus brotantes. A su vez, la diseminación posterior del virus puede indicar si la infección con estos brotantes se limita a la célula primaria o puede transmitirse a células secundarias. Se indican las conclusiones que surgirían de cada resultado. El virus brotante que aparece como resultado de la transfección de células High Five ${ }^{\mathrm{TM}}$ con bApGOZA aparece tachado porque si en estas condiciones se produjeran brotantes, el gen 1629 no sería esencial para la infección en cultivo celular. Se destacan en rojo los resultados hallados en este trabajo. 
a
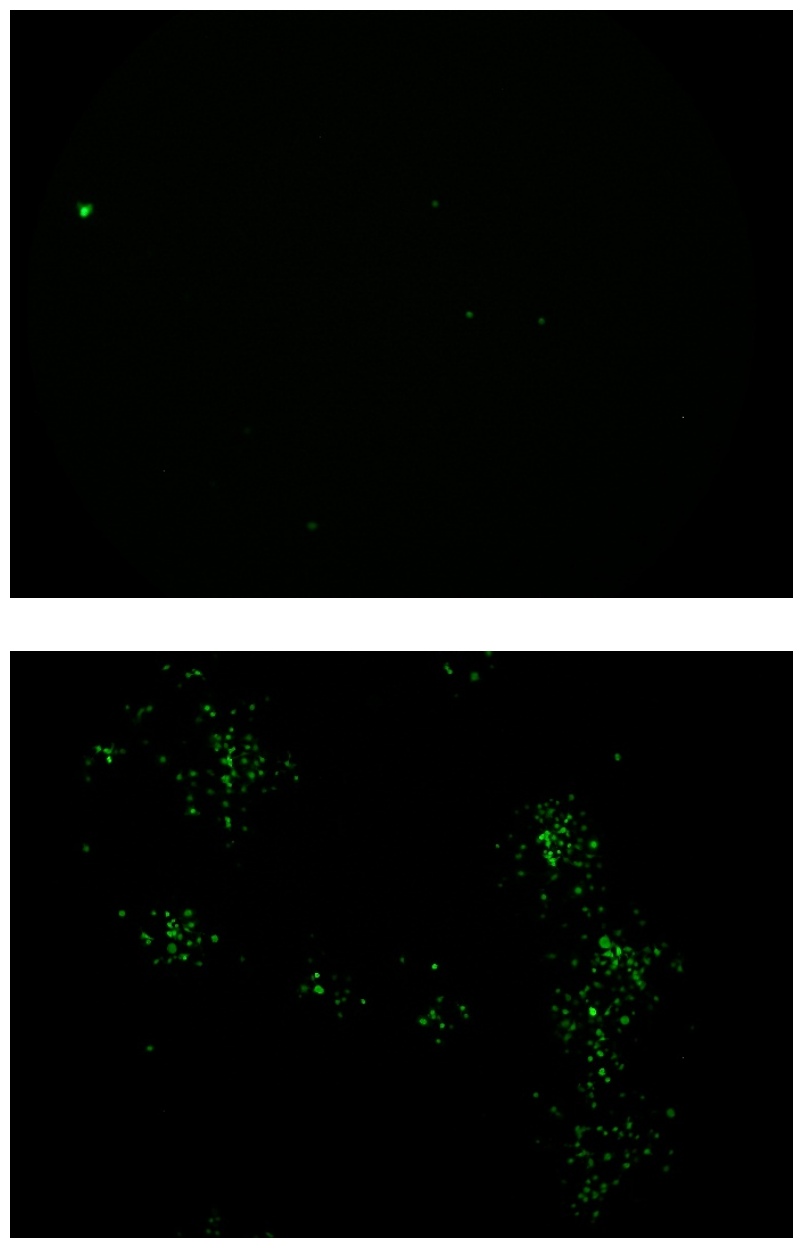
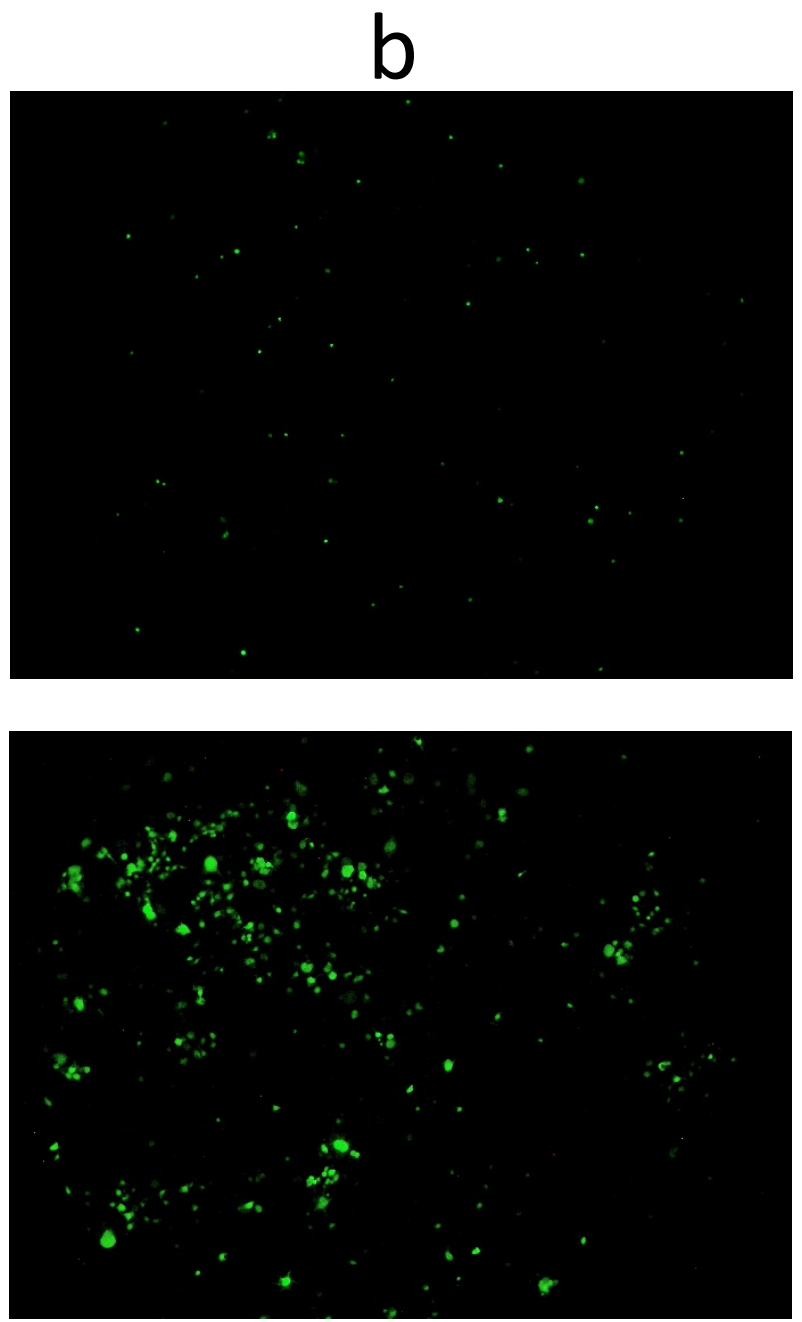

Figura 6.7. Línea XXL-GFP infectada con viriones brotantes de bApGOZA generados en la línea celular complementadora 1629AgMNPV (columna (a)) y con viriones de AcMNPV-lacZ-polh-como control positivo (columna (b)), a tiempos cortos (1 dpi), (arriba) y largos (15 dpi para bApGOZA y 7 dpi para AcMNPV-lacZ-polh-), (abajo) de infección.

Para verificar que esta dispersión no se debe a la presencia de viriones brotantes Se utilizaron sobrenadantes de High Five ${ }^{\mathrm{TM}}$ transfectadas con bApGOZA y de células XXLGFP infectadas con virus brotantes de bApGOZA previamente producidos en la línea 1629AgMNPV para infectar células XXL-GFP. Finalmente, se verificó que las células High Five $^{\mathrm{TM}}$ infectadas con bApGOZA no producen virus brotantes (carecen de la proteína 1629). En ninguno de los dos casos se observó fluoresencia, lo que indica que no había virus brotantes en ninguno los sobrenadantes de las células que no expresan el gen 1629 (Figura 6.9). 

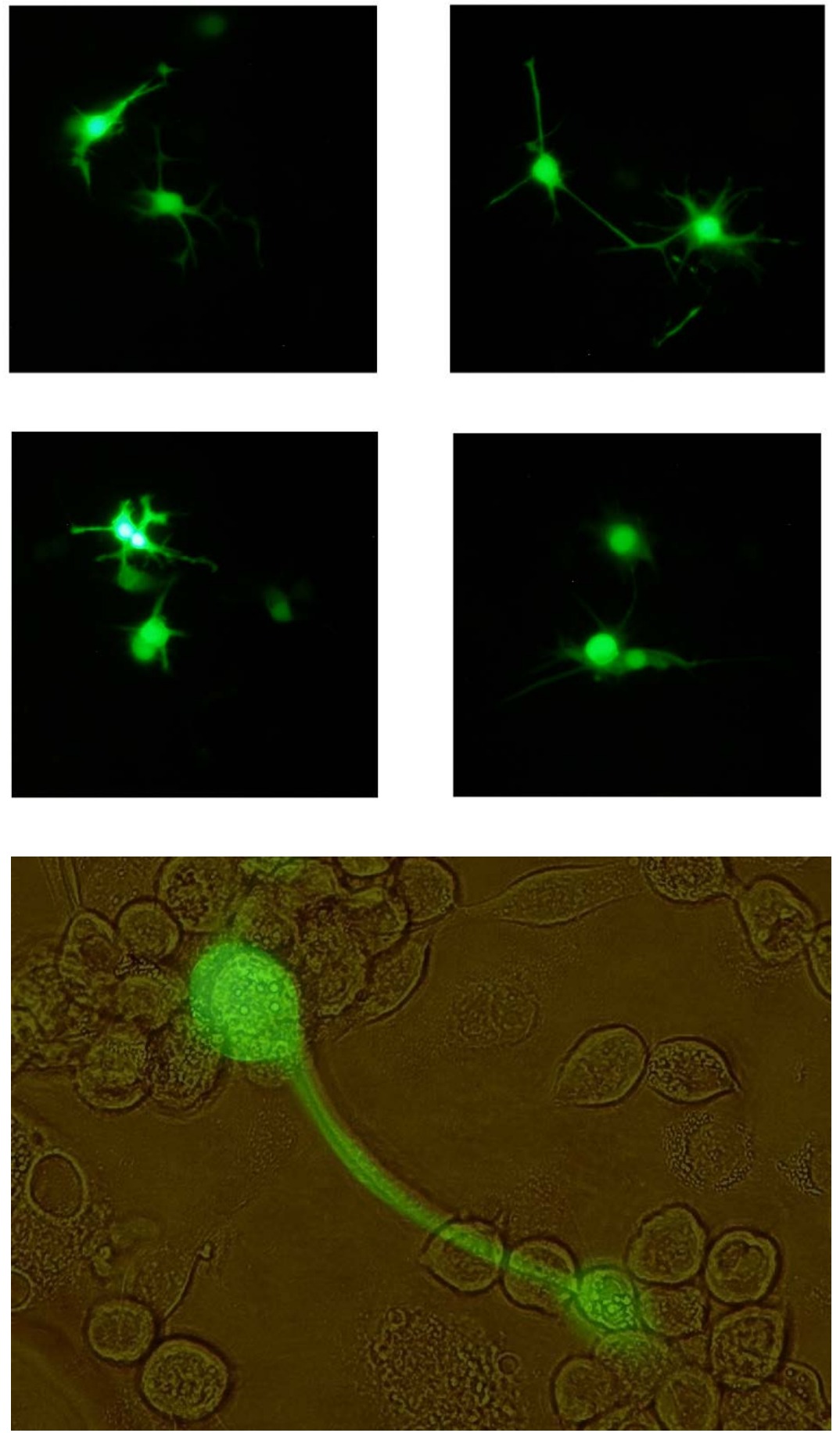

Figura 6.8. Células XXL-GFP infectadas con bApGOZA. Se puede observar la conexión entre células infectadas a través de filopodios. En la imagen inferior, que corresponde a una superposición entre microscopía visible y de fluorescencia, se pueden observar cuerpos de oclusión en las dos células conectadas. Además, se pueden apreciar dos no infectadas células debajo del filopodio que conecta las células. 

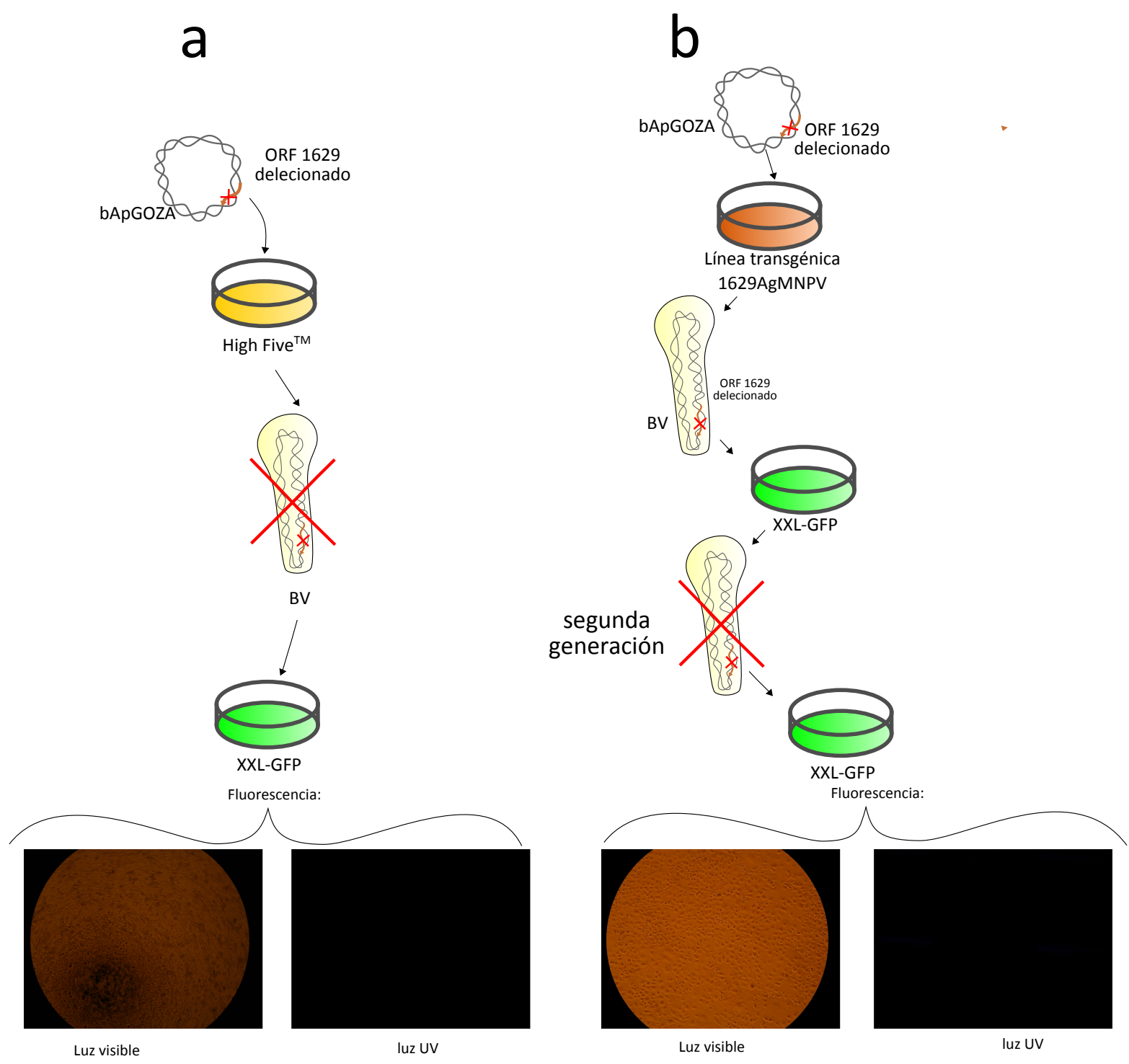

Figura 6.9. Esquema y microscopías de los controles de producción de virus brotantes de bApGOZA. Los sobrenadantes de High Five ${ }^{\mathrm{TM}}$ transfectadas con bApGOZA y de células XXL-GFP infectadas con virus brotantes de bApGOZA previamente producidos en la línea 1629AgMNPV se utilizaron para infectar células XXL-GFP.

\subsubsection{Desarrollo de un vector de transferencia para la deleción de 1629 de AgMNPV.}

Para generar un AgMNPV recombinante deficiente el gen 1629 se desarrolló el vector de transferencia pi3- $\Delta 1629 \mathrm{GFP}$, que al recombinar con el virus parental AgMNPV-I-Ppol produciría una deleción en este gen (Figura 6.2). Este vector permitirá, además, la purificación de virus recombinantes por la expresión del gen indicador GFP. 


\subsubsection{Recombinación de AgMNPV-I-Ppol con el vector de transferencia pl3- 1 1629GFP}

Se cotransfectaron células High Five-1629Ag con el virus parental AgMNPV-I-Ppol digerido con I-Ppol y el vector de transferencia pl3- $\Delta$ 1629GFP. La doble recombinación homóloga entre el virus y el plásmido resultaría en la eliminación de una parte del gen 1629 del virus y la incorporación de GFP bajo el promotor de poliedrina. Luego de siete días a partir de la transfección, se observó la presencia de fluorescencia en algunas células (Figura 6.10).

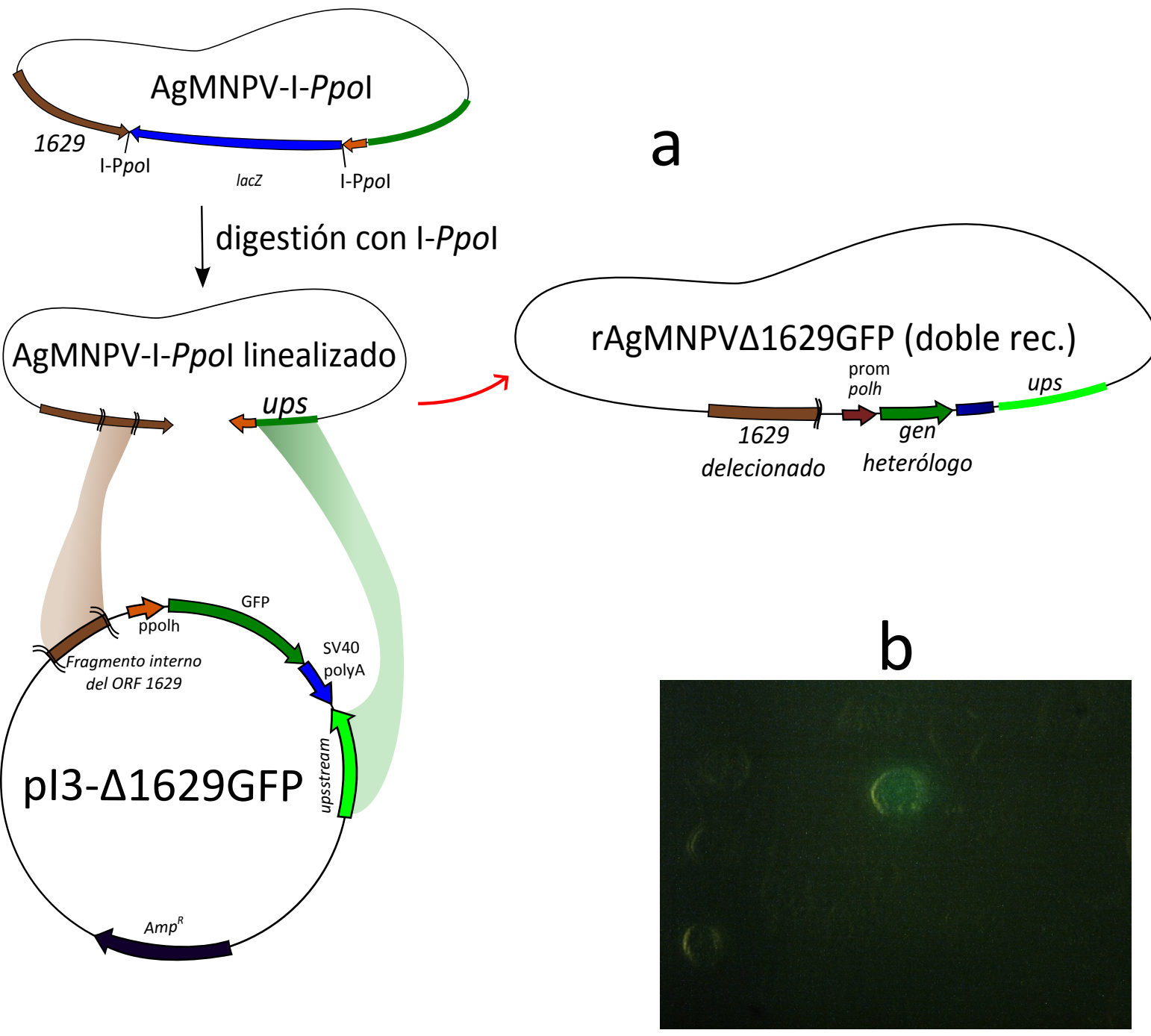

Figura 6.10. a) Generación del vector de transferencia para la deleción del gen 1629 de AgMNPV: pl3$\triangle 1629 \mathrm{GFP}$. b) esquema de la recombinación homóloga para la generación del AgMNPV delecionado en 1629 (AgMNPVD1629GFP). Para la generación de este virus recombinante es necesario el desarrollo de la línea celular transgénica complementadora. c) células cotransfectadas con el virus AgMNPV linealizado y el plásmido pl3- 1629 GFP. Se observa una célula que expresa GFP, producto de la recombinación entre el virus parental y el vector de transferencia. 


\subsection{Discusión}

Se desarrolló una línea celular transgénica que expresa el gen 1629 de AgMNPV de forma constitutiva con la intención de poder generar y mantener un virus AgMNPV deficiente en este gen. Este virus podría ser utilizado para generar recombinantes de AgMNPV de una forma muy eficiente. Se ha avanzado en el desarrollo de un vector para generar una deleción dirigida del gen 1629 de AgMNPV que a su vez resulte en la transferencia del gen indicador GFP. La cotransfección de células High Five ${ }^{\mathrm{TM}}$ con el virus AgMNPV-I-Ppol linealizado y el vector de selección pl3-41629GFP dio lugar a aparición de células que expresan GFP, indicando que la recombinación tuvo lugar. Sin embargo, aún no se ha finalizado el aislamiento y la caracterización del recombinante.

Cabe destacar que para la construcción y aislamiento de este recombinante se necesita contar con la línea celular complementadora High Five-1629Ag.

Para poner a punto la metodología de recombinación y evaluar la eficiencia de la complementación de un virus deficiente por parte de la línea celular High Five-1629Ag, se recurrió a un virus deficiente en 1629 de la especie AcMNPV (bApGOZA). Llamativamente, se encontró que este virus era capaz de generar cuerpos de oclusión (activando la transcripción tardía y, presumiblemente, replicando) al ser transfectado en células High Five ${ }^{\mathrm{TM}}$. Es decir que la ausencia de 1629 en el genoma viral solo se siente en la producción de BVs; no impide la replicación del DNA ni la expresión de genes tardíos. Considerando que la proteína 1629 ha encontrado localizada en ODV, resultaría interesante determinar si estos $\mathrm{OB}$ generados en ausencia de esta proteína contienen ODV en su interior y cuál es su morfología.

Los sobrenadantes, con presuntos viriones brotantes de bApGOZA, generados en la línea celular que expresa 1629 de AgMNPV (1629AgMNPV), se utilizaron para infectar la línea celular XXL-GFP. La detección de fluorescencia en esta línea indicadora demostró, por un lado, que la línea celular High Five-1629Ag puede complementar exitosamente la deficiencia de 1629 en el virus bApGOZA (lo cual resulta esperable en base al alto nivel de similitud entre las proteínas de ambas especies de $35 \%$ de identidad). Es decir que, al igual que ocurrió con el gen de poliedrina (capítulo 3), la proteína 1629 de AgMNPV complementa la ausencia de su homóloga de AcMNPV. Además, se observó 
que el virus puede ocasionar infecciones secundarias generando una placa de infección, demostrando que es capaz de dispersarse. Como se observó que el virus no es capaz de transmitirse a través del sobrenadante (virus brotantes) si no es mantenido en una línea complementadora, se presume que 1629 es indispensable para la formación de viriones brotantes funcionales. Sin embargo, se observa que el virus aún puede dispersarse entre células en ausencia de 1629, probablemente a través de transmisión directa de célula a célula. Este fenómeno se daría a través de las extensiones celulares que conectan a las células.

Existe la posibilidad de que la transmisión de baculovirus entre células adyacentes sea un fenómeno común en cultivos celulares en monocapa, ya que se observaron células en contacto infectadas incluso cuando se utilizó un virus que contiene el gen 1629 completo. Se ha demostrado que algunos virus de plantas que son transmitidos por insectos explotan los mecanismos de transporte célula a célula para su propagación en el vector (Chen et al., 2012), un fenómeno que también se observa en cultivos celulares de insecto.

Estas observaciones deben confirmarse con experimentos de miscroscopía confocal, marcando proteínas de la nucleocápside y con experimentos de microscopía electrónica de transmisión de cortes ultrafinos de cultivos celulares infectados. 


\section{Referencias}

Chen, Q.; Chen, H.; Mao, Q.; Liu, Q.; Shimizu, T.; Uehara-Ichiki, T.; Wu, Z.; Xie, L.; Omura, T.; Wei, T. (2012). Tubular structure induced by a plant virus facilitates viral spread in its vector insect. PLoS Pathog, 8 (11), e1003032. doi: 10.1371/journal.ppat.1003032

Haase, S.; Ferrelli, M.L.; Pidre, M.L.; Romanowski, V. (2013). Genetic Engineering of Baculoviruses, Current Issues in Molecular Virology - Viral Genetics and Biotechnological Applications, Prof. Victor Romanowski (Ed.) ISBN: 978-953-51-1207-5, InTech, DOI: 10.5772/56976.

Hilton, S.; Kemp, E.; Keane, G.; Winstanley, W. (2008). A bacmid approach to the genetic manipulation of granuloviruses. J. Virol. Methods., 152 (1-2), 56-62

Hou, S.; Chen, X.; Wang, H.; Tao, M.; Hu, Z., (2002). Efficient method to generate homologous recombinant baculovirus genomes in E. coli. Biotechniques 32, 783-788.

InsectSelect ${ }^{\mathrm{TM}}$ BSD System, I. (2008). For Stable Expression of Heterologous Proteins in Lepidopteran Insect Cell Lines using pIB/V5-His Catalog nos. K820-01, K825-01, V8020-01.

Iorio, C.; Vialard, J.E.; McCracken, S.; Lagace, M.; Richardson, C.D. (1998). The late expression factors 8 and 9 and possibly the phosphoprotein p78/83 of Autographa californica multicapsid nucleopolyhedrovirus are components of the virus-induced RNA polymerase. Intervirology, 41 (1), 35-46.

Je, Y.H.; Chang, J.H.; Choi, J.Y.; Roh, J.H.; Jin, B.R.; O'Reilly, D.R.; Kang, S.K. (2001). A defective viral genome maintained in Escherichia coli for the generation of baculovirus expression vectors. Biotechnology Letters, 23 (8), 575-582.

Je, Y.H.; Chang, J.H.; Roh, J.H.; Jin, B.R. (2001). Generation of Baculovirus Expression Vector Using Defective Autographa californica Nuclear Polyhedrosis Virus Genome Maintained in Escherichia coli for $\mathrm{Occ}^{+}$Virus Production. Int. J. Indust. Entomol., 2 (2), 155-160.

Luckow, V.A.; Lee, S.C.; Barry, G.F.; Olins, P.O., (1993). Efficient generation of infectious recombinant baculoviruses by site-specific transposon-mediated insertion of foreign genes into a baculovirus genome propagated in Escherichia coli. J. Virol. 67, 4566-4579.

Moscardi, F. (1999). Assessment of the application of baculoviruses for control of Lepidoptera. Annu. Rev. Entomol., 44, 257-289.

Motohashi, T.; Shimojima, T.; Fukagawa, T.; Maenaka, K.; Park, E.Y. (2005). Efficient large-scale protein production of larvae and pupae of silkworm by Bombyx mori nuclear polyhedrosis virus bacmid system. Biochem. Biophys. Res. Commun. 326, 564-569.

Pijlman, G.P.; Dortmans, J.C.F.M.; Vermeesch, A.M.G.; Yang, K.; Martens, D.E.; Goldbach, R.W.; Vlak, J.M. (2002). Pivotal role of the non-hr origin of DNA replication in the genesis of defective interfering baculoviruses. J. Virol. 76, 5605-5611.

Wang, H.Z.; Deng, F.; Pijlman, G.P.; Chen, X.W.; Sun, X.L.; Vlak, J.M.; Hu, Z.H. (2003). Cloning of biologically active genomes from a Helicoverpa armigera single-nucleocapsid nucleopolyhedrovirus isolate by using a bacterial artificial chromosome. Virus Res. 97, 57-63. 



\section{Conclusiones y perspectivas}


La utilización de los baculovirus como insecticidas ha experimentado un incremento en las últimas décadas. Esto se debe a varias razones. En primer lugar, algunos gobiernos han apoyado el desarrollo de programas de manejo integrado de plagas debido a que algunos de los efectos secundarios a nivel ambiental y humano ocasionados por los plaguicidas químicos se han vuelto evidentes. La restricción de la comercialización de alimentos derivados de cultivos transgénicos en el mercado europeo ha limitado la utilización de los paquetes tecnológicos comercializados por las grandes empresas proveedoras de productos para la agricultura, que generalmente recomiendan la aplicación conjunta de plaguicidas de amplio espectro y herbicidas o bien expresan polipéptidos con capacidad insecticida como componentes transgénicos (como el caso de las variedades de maíz transgénico que expresan proteínas Cry de Bacillus thuringiensis, patentadas por Monsanto), ha acelerado también a la búsqueda de alternativas de producción orgánica.

En segundo lugar, algunos agricultores han experimentado el surgimiento de resistencia a plaguicidas químicos con daños masivos en los cultivos y esto ha colaborado a desarrollar una postura más abierta a la utilización de medidas de control de plagas alternativas.

En tercer lugar, los avances en la investigación en el tema han conducido a un incremento en la diversidad de baculovirus disponibles (permitiendo el control de un número mayor de plagas) y a una mejora sustancial en la calidad de las formulaciones basadas en baculovirus.

El incremento del interés en los baculovirus a nivel regional se ve reflejado en que cerca de veinte baculovirus se comercializan actualmente en Latinoamérica.

A pesar de esto, la utilización de los baculovirus en el mercado agrícola no ha experimentado aún su máximo potencial. Un ejemplo que grafica claramente este concepto consiste en el de la aplicación de AgMNPV en cultivos de soja en Brasil. Durante más de una década la utilización de este baculovirus resultó una alternativa competitiva frente a los plaguicidas químicos, para lo cual se conjugaron una serie de circunstancias particulares que convirtieron al virus en una opción de control atractiva. Por un lado, Anticarsia gemmatalis fue durante mucho tiempo la única plaga en los cultivos de soja en Brasil. Por otro lado, el virus resulta muy patogénico y su acción 
es bastante rápida en climas cálidos y por lo tanto detiene el daño sobre los cultivos de manera efectiva. Por otra parte, la disponibilidad de trabajo de baja calificación barato permitió el desarrollo de métodos de producción basados en la recolección manual con costos muy bajos.

A pesar de estas circunstancias, en los últimos años, las prácticas de cultivo de soja en Brasil cambiaron y la mayoría de los agricultores optaron por la siembra directa, recurriendo a la aplicación de plaguicidas químicos para la eliminación de plagas en las malezas residuales. De esta forma se eliminó la diversidad natural de insectos que subsisten en las malezas y esto derivó en el surgimiento de nuevas plagas relegando considerablemente el uso de AgMNPV.

Considerando este antecedente, es importante reconocer la debilidad de los programas de baculovirus frente a la utilización de paquetes tecnológicos y prácticas que no ponderan la importancia de proteger el equilibrio ecológico en el ecosistema del cultivo.

Ante esta conclusión, resulta claro el rol trascendental que tiene la educación y la concientización en el éxito de los programas de control biológico. Esto refuerza la necesidad de un compromiso entre las políticas gubernamentales, los centros de extensión, los investigadores, los agricultores y la población en general.

Por otra parte, la investigación y el desarrollo deben focalizarse en incrementar la competitividad de los baculovirus frente a los pesticidas de acción rápida, para convertirlos en alternativas atractivas aún en escenarios alejados de la idealidad. Una parte de este desarrollo debe destinarse al mejoramiento de la performance de los baculovirus como insecticidas. En este contexto, la biología molecular ofrece herramientas para la modificación genética de los baculovirus y la expresión de genes a través de líneas celulares transgénicas y a lo largo de esta tesis se han descripto varias estrategias que hacen uso de estas herramientas para el mejoramiento de AgMNPV.

En una primera etapa, se desarrolló un sistema de recombinación para la modificación genética de AgMNPV. Se demostró la eficiencia de este sistema de recombinación a través de la generación de un virus recombinante que expresa GFP y resulta infectivo por vía oral. Se han desarrollado, además, vectores de transferencia con genes que son 
candidatos a incrementar las propiedades insecticidas de AgMNPV, estableciendo las bases para la generación de AgMNPV recombinantes mejorados.

Las perspectivas en este tema consisten en el desarrollo de AgMNPV con capacidad insecticida mejorada, a través de la expresión de toxinas específicas contra artrópodos o genes de baculovirus ausentes en AgMNPV con potencialidad de aumentar la velocidad de ingreso del virus y su evaluación a través de ensayos biológicos en laboratorio y, finalmente, ensayos a campo con contención biológica.

Considerando las precauciones referentes a la liberación de organismos genéticamente modificados, se planteó la posibilidad de desarrollar baculovirus que no resultaran capaces de dispersarse autónomamente en el ambiente. Para esto, se desarrollaron líneas celulares transgénicas que expresan la proteína mayoritaria del cuerpo de oclusión, poliedrina. De esta forma se consiguió generar cuerpos de oclusión de virus con un genotipo poliedrina negativo ( $\left.p o / h^{-}\right)$. Como se describió anteriormente, estos virus poseen la capacidad de infectar larvas por vía oral, pero no se pueden producir nuevos cuerpos de oclusión en las larvas infectadas, limitando de esta forma su dispersión.

Los resultados obtenidos en este tema indican que los cuerpos de oclusión generados en las líneas celulares generadas son infectivos en larvas, resultando en una prueba de concepto satisfactoria. En particular, se espera que la oclusión del virus AgMNPV-tox34polh ${ }^{-}$resulte en un virus con un tiempo de acción menor al virus salvaje, aunque aún no se han llevado a cabo los ensayos biológicos correspondientes.

Las perspectivas relacionadas a este tema son muy amplias. Por una parte, para completar el estudio de la complementación funcional de poliedrina entre las especies AcMNPV y AgMNPV es necesario llevar a cabo ensayos de actividad de los cuerpos de oclusión trans-ocluidos y estudiar su morfología por microscopía electrónica.

Además, se presenta la posibilidad de estudiar la dispersión de los poliedros transocluidos desde una perspectiva ecológica, evaluando la probabilidad de adquisición del gen de poliedrina por transferencia horizontal en la naturaleza.

El sistema de experimentación basado en el desarrollo líneas celulares transgénicas ha demostrado, además, ser muy versátil y esto alienta su aplicación al estudio del gen de 
poliedrina y su interacción con los viriones, mediante el desarrollo de líneas que expresen diferentes mutantes de este gen. Por otra parte, surge la posibilidad de insertar polipéptidos con capacidad insecticida en la estructura polipeptídica de la poliedrina utilizando líneas celulares, lo cual permitiría mejorar el tiempo de acción del virus sin necesidad de modificar su estructura genética.

Se desarrolló también una línea celular que expresa un gen indicador (GFP) bajo el control de un promotor viral inducible por infección. Esta línea celular permite la titulación, el monitoreo de baculovirus y es una herramienta esencial en el estudio básico, como se demostró al utilizarla posteriormente en el estudio del virus bApGOZA deficiente en el gen 1629.

Por otra parte, se efectuó un estudio de los elementos regulatorios de los baculovirus que condujo a la conclusión de que los promotores de betabaculovirus (EpapGV) son reconocidos por los factores transcripcionales de alfabaculovirus (AgMNPV), aunque de manera poco eficiente. Es posible que esto sea una consecuencia del alto grado de divergencia de los baculovirus que derivó en la diferenciación de los factores transcripcionales y de las secuencias promotoras y es probable que la transcripción baja sea un factor importante en la determinación del rango de hospedador. Este resultado, además, plantea un desafío adicional en el concepto de la recombinación entre dos baculovirus como estrategia para la modificación del rango de hospedador. Las perspectivas de este tema incluyen la cuantificación del ensayo utilizando citometría de flujo y PCR cuantitativa con transcripción inversa (RT-qPCR) y la incorporación una mayor cantidad de promotores al ensayo.

Finalmente, se realizaron avances en el desarrollo de un sistema de recombinación de alta eficiencia para AgMNPV. Se utilizó para este desarrollo el modelo de los sistemas de recombinación de AcMNPV basados en baculovirus con deleciones en el gen 1629. De acuerdo a la bibliografía el gen 1629 es esencial para la transmisión del virus en cultivo celular, y se indica que la ausencia de este gen resulta en la incapacidad del virus para generar viriones brotantes. Sin embargo, no se encuentran estudios acerca de los eventos del curso de la infección que tienen lugar en una célula infectada o transducida con un virus deficiente en este gen. 
Cuando se decidió analizar la transmisión de un virus AcMNPV deficiente en el gen 1629, se encontró que este virus es capaz de activar la transcripción tardía y se observó aparición de poliedros en células infectadas. Además, utilizando la línea celular transgénica desarrollada en este trabajo, se observó en varias ocasiones la aparición de células en contacto a través de las extensiones celulares simultáneamente infectadas. Este podría ser un indicio de transmisión del virus entre células por contacto directo, un fenómeno no descripto aún para los baculovirus.

Los resultados de esta última serie de experimentos, aunque son preliminares, establecen un modelo de estudio para continuar profundizando la investigación y confirmar estas observaciones. En este contexto es interesante indagar en la importancia de este mecanismo de transmisión en la invasión de las células epiteliales intestinales y otros tejidos.

En resumen, se han desarrollado varias herramientas que establecen bases importantes para el mejoramiento de AgMNPV. Se ha utilizado un enfoque clásico, que derivó en el desarrollo de un sistema para la incorporación de nuevas secuencias (genes) en el genoma de AgMNPV y un enfoque más novedoso que involucra la utilización de líneas celulares transgénicas para la modificación de sus propiedades bioinsecticidas sin introducir cambios en el genoma viral, con la ventaja de que no es necesaria la introducción de genes modificados en el ambiente al utilizar un insecticida baculoviral. Finalmente, el estudio de la transducción de un baculovirus deficiente en un gen esencial a través del uso de líneas celulares complementadoras de la línea indicadora reveló indicios de un posible mecanismo de transmisión de baculovirus sin precedentes para esta familia. 


\section{Anexo}





\section{A - Materiales y Métodos}

\section{A.1. Materiales}

\section{A.1.1. Productos químicos y enzimáticos}

Durante el desarrollo del presente trabajo se utilizaron reactivos de grado analítico o de grado biología molecular suministrados por Merck (Darmstadt, Alemania), Sigma (St. Louis, USA) y Carlo Erba (Milano, Italia). Las enzimas utilizadas fueron provistas por las empresas Stratagene (La Jolla, USA), Promega (Madison, USA), New England Biolabs (Beverly, USA) y Gibco BRL- Life Technologies (Grand Island, USA). Los componentes de los medios de cultivo para bacterias se adquirieron en Difco (Detroit, EE.UU.). LoS medios de cultivo de células eucariotas fueron suministrados por Gibco BRL (Grand Island, USA) y los sueros fetales por Bioser (Buenos Aires, Argentina). Las cajas de Petri y los frascos de poliestireno, utilizados en el cultivo de células fueron provistos por Nunc (Kamstrup, Dinamarca) y Corning (USA). Las fotografías se obtuvieron con un equipo de Electrophoresis Documentation and Analysis System 120 (Kodak digital science) o capturador de imágenes Epichemi3 Darkroom (UVP Bioimaging Systems). Para la toma de imágenes se utilizó un scaner VistaScan 240. La cuantificación de muestras se realizó por medidas de absorbancia; con el programa LabWorksTM 4.6 (Image Acquisition and Analysis Software) o con Nanodrop Spectrophotometer ND-1000.

\section{A.1.2. Soluciones}

Todas las soluciones preparadas fueron esterilizadas por tratamiento de calor en autoclave a $121^{\circ} \mathrm{C}$ a 1 atmósfera de sobrepresión. Las soluciones termolábiles fueron esterilizadas por filtración con filtro de diámetro de poro de $22 \mu \mathrm{m}$. El agua utilizada en las soluciones fue bidestilada, filtrada por columna de intercambio iónico y esterilizada en autoclave.

\section{A.1.2.1 Soluciones para la extracción de plásmidos}

Alcoholes: Etanol $96 \%$ y $70 \%$.

Solución I: Glucosa 50 mM, Tris- $\mathrm{HCl} 25 \mathrm{mM}$ (pH=8) EDTA $1 \mathrm{mM}$

Solución II: $\mathrm{NaOH} 0,2 \mathrm{~N}$; SDS $1 \%$

Solución III: AcOK 5M. pH=4.8

Buffer TE: Tris-HCl $10 \mathrm{mM}$ (pH=8) EDTA $1 \mathrm{mM}$

$\mathrm{NaAcO} 3 \mathrm{M}$ : se pesó 246.1 gramos de $\mathrm{NaAcO}$ y se disolvió en agua bidastilada. Se llevó a pH 5,2 con

ácido acético glacial y se añadió agua hasta llegar a un volumen final de $1 \mathrm{~L}$.

Cloroformo:Isoamílico (24,1): 24 partes de cloroformo y 1 parte de alcohol isoamílico.

Fenol: Solución de fenol equilibrada con fase acuosa pH 8

\section{A.1.2.2. Soluciones de antibióticos}

Los antibióticos se disolvieron en agua bidestilada estétil a una concentración final de $100 \mathrm{mg} / \mathrm{ml}$ y se esterilizaron por filtración.

\section{A.1.2.3. Soluciones para la resolución de ácidos nucleicos mediante electroforésis}

Buffer de corrida TAE (Tris-HCl, ácido acético, EDTA) 50 X: 242 Tris base, 57,1 ml ácido acético glacial y $100 \mathrm{mM}$ EDTA 0,5 M pH=8,0. Completado a $1 \mathrm{~L}$ con agua.

TAE 1X: Tris-Acetato $40 \mathrm{mM}$, EDTA $1 \mathrm{mM}$.

Solución Stock Bromuro de etidio: $10 \mathrm{mg} / \mathrm{ml}$ BrEt, conservado en oscuridad.

Geles Agarosa: Agarosa 0,3\% - 2\% en buffer TAE 1X.

Solución de siembra: TAE 1X, Glicerol 30\% y colorantes Xilen cianol FF y azul de bromofenol. 
A.1.2.4. Soluciones para el análisis de proteínas mediante electroforesis en geles de poliacrilamida con SDS

Gel separador: 18, 12, ó 10\% dependiendo del experimento. El gel se prepara a partir de una solución concentrada de acrilamida:bisacrilamida (29:1) diluyendo en buffer de separación 1 X: 0,375 M Tris-HCl pH 8,8; 0,1\% SDS. Se agrega además persulfato de amonio y TEMED al 0,1 y 0,01\%, respectivamente.

Gel concentrador: $5 \%$. El gel se prepara a partir de una solución concentrada de acrilamida:bisacrilamida $(30 ; 0,8)$ diluyendo en buffer concentrador 1 X: 125 mM Tris-HCl pH 6,8; 0,1\% SDS. Se agrega además persulfato de amonio y TEMED al 0,1 y 0,01\%, respectivamente.

Buffer de corrida $1 \mathrm{X}$ :

Tris base $25 \mathrm{mM}$

glicina pH 8,3 $250 \mathrm{mM}$

SDS $0,1 \%$

Solución para siembra de muestras $4 \mathrm{X}$ :

Tris-HCl pH 6,8 200 mM

glicerol $40,0 \%$

SDS $8,0 \%$

$\beta$-mercaptoetanol $8,0 \%$

azul de bromofenol $0,4 \%$

Solución de tinción:

Coomassie Brilliant Blue R-250 0,25\% p/v

metanol $45 \% \mathrm{v} / \mathrm{v}$

ácido acético $10 \% \mathrm{v} / \mathrm{v}$

Se lleva a $100 \mathrm{ml}$ con $\mathrm{H} 2 \mathrm{O}$.

Solución de destinción:

etanol $30 \% \mathrm{v} / \mathrm{v}$

ácido acético $10 \% \mathrm{v} / \mathrm{v}$

\section{A.1.2.5. Soluciones utilizadas en reacciones enzimáticas:}

Las distintas reacciones de digestión se llevaron a cabo incubando el DNA a digerir con la enzima correspondiente, teniendo en cuenta la actividad de la enzima y utilizando el buffer de digestión, la cantidad de enzima y el tiempo y temperatura de incubación recomendados por el proveedor. Los volúmenes de digestión variaron con la masa de DNA digerido de $5 \mu \mathrm{l} \mathrm{a} 100 \mu \mathrm{l}$.

\section{A.1.3. Cepas bacterianas}

Para el desarrollo de este trabajo se utilizaron las cepas la cepa de Escherichia coli DH5 $\alpha^{\mathrm{TM}}$ y Top10, que posee los siguientes genotipos:

DH5 $\alpha^{\text {TM }}$ : F- $\phi 80$ lacZ $\Delta$ M15 $\Delta$ (lacZYA-argF) U169 deoR recA1 endA1 hsdR17 (rk-, mk+) phoA supE44 $\lambda$ - thi-1 gyrA96 relA1 tonA (Invitrogen, Carlsbad, CA, USA).

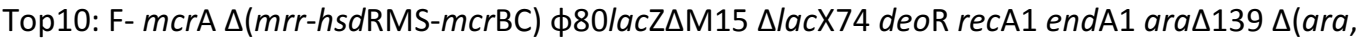
leu)7697 ga/U ga/K $\lambda$ - rpsL(StrR) nupG (Invitrogen, Carlsbad, CA, USA).

\section{A.1.4. Medios}

\section{A.1.4.1. Medios para cultivo de bacterias}

Medio LB: se disuelven $5 \mathrm{~g}$ de $\mathrm{NaCl}, 10 \mathrm{~g}$ de triptona y $5 \mathrm{~g}$ de extracto de levadura en aproximadamente $700 \mathrm{ml}$ de agua destilada, se lleva a pH neutro. Una vez disueltos los reactivos se ajusta el volumen a 1 litro con agua destilada. Se esteriliza en autoclave. Para preparar medios sólidos se agrega $15 \mathrm{~g}$ de ágar por cada litro de medio líquido.

\section{A.1.4.2. Antibióticos para cultivo de bacterias}

Ampicilina: se disuelven $100 \mathrm{mg}$ en $1 \mathrm{ml}$ de agua bidestilada estéril. Se esteriliza por filtración. Esta solución se considera 1000x. 


\section{A.1.4.3. Medios para cultivo de células de insectos}

TC-100 (JHR Biosciences) suplementado con 10\% de suero fetal bovino (Bioser, Buenos Aires, Argentina) y gentamicina $(50 \mu \mathrm{g} / \mathrm{ml})$.

Grace's (GIBCO) suplementado con $10 \%$ de suero fetal bovino (Bioser, Buenos Aires, Argentina) y gentamicina $(50 \mu \mathrm{g} / \mathrm{ml})$.

\section{A.1.4.4. Antifúngicos y Antibióticos para cultivo de células}

Anfotericina B: se disuelven 2,5 mg en $1 \mathrm{ml}$ de agua bidestilada estéril. Se esteriliza por filtración. Esta solución se considera 1000x.

Gentamicina: se disuelven $50 \mathrm{mg}$ en $1 \mathrm{ml}$ de agua bidestilada estéril. Se esteriliza por filtración. Esta solución se considera 1000x.

\section{A.2.Métodos}

\section{A.2.1. Técnicas que involucran DNA}

Se utilizaron las técnicas de clonado generales detalladas en (Green \& Sambrook, 2012).

\section{A.2.1.2. Preparación de DNA plasmídico}

La purificación de DNA plasmídico se efectuó por el método de lisis alcalina (Birnboim \& Doly, 1979).

Se crecieron bacterias E. coli (DH-5 $\alpha$ o TOP10) en medio LB hasta saturación con el antibiótico correspondiente. Se centrifugó 1,5 ml de estos cultivos a 14000-18000 x g durante 30 segundos en un tubo Eppendorf y se descartó el sobrenadante. Este procedimiento se repitió cinco veces sobre el mismo Eppendorf. Se añadieron $200 \mu \mathrm{l}$ de Solución I al sedimento obtenido y se lo resuspendió con vórtex. Luego se agregó $400 \mathrm{ml}$ de Solución II. Después se invirtió suavemente el tubo 5 a 10 veces o hasta observar la clarificación de la suspensión y se incubó en agua-hielo durante 5 min. Luego se neutralizó el pH con 300 $\mu \mathrm{l}$ de Solución III (a $4{ }^{\circ} \mathrm{C}$ ) y se incubó durante $2-5 \mathrm{~min}$ en agua-hielo. El tubo Eppendorf se centrifugó 5 minutos a $14.000-18.000 \times \mathrm{g}$ a $4^{\circ} \mathrm{C}$ y se extrajo el sobrenadante (DNA plasmídico) evitando tomar el precipitado de DNA romosómico, restos celulares y proteínas acomplejadas con el SDS. Los RNA celulares de esta solución se degradaron por incubación con RNAsa A $(20 \mathrm{\mu g} / \mathrm{ml})$ durante $30 \mathrm{~min}$ a 37 oC. EL DNA plasmídico se aisló de las proteínas por dos extracciones sucesivas con fenol y cloroformo/isoamílico (24:1) y se concentró por precipitación etanólica o con isopropanol. La preparación plasmídica se purificaron luego con polvo de sílica.

\section{A.2.1.3. Extracción fenólica}

Este método se empleó para separar proteínas de soluciones de ácidos nucleicos de preparaciones de viriones de AgMNPV tratados con proteinasa K. El DNA se extrajo con un volumen de fenol para eliminar proteínas. Una vez añadida la solución orgánica al tubo, se mezcló suavemente por inversión durante 10 min y se centrifugó durante 5 min a $14-18000$ x g y se tomó la fase acuosa tratando de no extraer material de la interfase. El procedimiento se repitió con cloroformo-isoamílico (24:1).

\section{A.2.1.4. Precipitación de ácidos nucleicos}

Los DNA virales fueron precipitados mediante la adición de 0,1 volúmenes (vol) de AcNa $3 \mathrm{M}$ más 2,5 volúmenes de etanol $96 \%$. Alternativamente, se precipitaron los DNA por adición de 0,3 vol de AcNa $3 \mathrm{M}$ más 0,6-0,9 volúmenes de alcohol isopropílico. En cualquiera de los dos protocolos, las soluciones se centrifugaron a 14.000 x g y ${ }^{\circ} \mathrm{C}$ durante $30 \mathrm{~min}$. Las sales fueron lavadas con solución de etanol $70 \%$, preparado con agua bidestilada estéril. El sedimento se secó a temperatura ambiente. El DNA se resuspendió en agua bidestilada estéril.

\section{A.2.1.5. Electroforesis en geles de agarosa}

Se pesó agarosa en un frasco de vidrio, se añadió buffer TAE (con Bret 0,5 $\mu \mathrm{g} / \mathrm{ml}$ ) y se calentó en horno microondas hasta disolución de la agarosa en el buffer. Una vez que la agarosa se enfrió, pero aún se encontraba en estado líquido, se colocó un volumen conveniente sobre un molde acrílico con un peine para generar calles de siembra de muestra. Una vez gelificada la agarosa, el gel se colocó en una cuba de 
electroforesis y se lo cubrió con buffer TAE. Las muestras de DNA se mezclaron con buffer de muestra en una relación buffer/muestra correspondiente y se depositaron dentro de las calles del gel. Los DNA se resolvieron en geles de agarosa aplicando un voltaje entre 80-120 V en caso que los tamaños de los fragmentos fueran pequeños o de 50-70 V para fragmentos grandes y porcentajes de geles bajos $(0,3-$ $0,6 \%)$. Los geles de agarosa se resolvieron en aparatos BIO-RAD. Los DNA se visualizaron por iluminación con transiluminadores de luz ultravioleta de $310 \mathrm{~nm}$ (Fotodyne, EE.UU. o Stratagen, EE.UU.) y las imágenes se capturaron con un aparato de documentación de geles Electrophoresis Documentation and Analysis System 120 (Kodak Digital Science).

\section{A.2.1.6. Purificación de fragmentos de DNA por adsorción de DNA a polvo de sílice}

Los fragmentos de DNA o de productos de amplificación, se purificaron a partir de geles de agarosa por adsorción a polvo de sílice (Geneclean Bio 101 Inc.). Se extrajo la porción del gel con la banda de interés y se incubó en 3 volúmenes de Nal saturado durante $5 \mathrm{~min}$ a $60^{\circ} \mathrm{C}$. Posteriormente, se resuspendió e $\mathrm{n}$ $20 \mu \mathrm{l}$ de polvo de sílice (previamente resuspendido) y se incubó con agitación durante $5 \mathrm{~min}$. La solución fue centrifugada durantes 10 segundos a 14-18.000 X g. El sobrenadante se descartó y el precipitado fue lavado con $200 \mu \mathrm{l}$ de solución $\mathrm{New}$ Wash $(\mathrm{NaCl}$, etanol y agua), este paso se repitió 2 veces. Este precipitado fue secado durante $5 \mathrm{~min}$ a temperatura ambiente y luego resuspendido en una cantidad conveniente de de agua bidestilada. Se centrifugó 30 seg a 14-18.000 X g y el sobrenadante con el DNA de interés se transfirió a otro tubo que fue conservado a $-20^{\circ} \mathrm{C}$ hasta su uso.

El protocolo anterior fue adaptado para la purificación de minipreps. En este caso, se agregaron 3 volumenes de $\mathrm{Nal}$ a la solución de miniprep y $20 \mu \mathrm{l}$ de polvo de sílice, siendo el resto de los pasos iguales.

\section{A.2.2. Métodos de transformación y screening}

\section{A.2.2.1. Preparación de bacterias E. coli electrocompetentes}

Se crecieron bacterias E. coli DH5 $\alpha$ hasta saturación. Ese cultivo se diluyó $1 / 20$ en medio LB $\sin \mathrm{NaCl}(1.000$ $\mathrm{ml}$ ) y se cultivó a $37^{\circ} \mathrm{C}$ con agitación de 180-220 rpm hasta alcanzar 0,5 a 0,6 unidades de densidad óptica a $600 \mathrm{~nm}$. En este punto, el cultivo se enfrió en agua hielo durante $30 \mathrm{~min}$. Posteriormente, se centrifugó el cultivo a $2800 \mathrm{G}$ durante 20 minutos a 4 으 y el sedimento de bacterias se resuspendió en $500 \mathrm{ml}$ de glicerol $10 \%(\mathrm{v} / \mathrm{v})$ preparado en agua bidestilada estéril. El proceso de resuspensión y centrifugación se repitió dos veces, disminuyendo el volumen de glicerol utilizado en los lavados, reuniendo los sobrenadantes resuspendidos de dos recipientes en uno. Finalmente, las bacterias se resuspendieron en $2 \mathrm{ml}$ de glicerol $10 \%$ o medio GYT, se separaron en alícuotas y se congelaron rápidamente a $-80{ }^{\circ} \mathrm{C}$ hasta el momento de su uso.

\section{A.2.2.2. Transformación de E. coli por electroporación}

La transformación de bacterias electrocompetentes se realizó en un electroporador Gene Pulser TM (BioRad, Hercules, CA, EE.UU.). Se mezclaron 50 de bacterias electrocompetentes con $2 \mu l$ reacción de ligación. Esta mezcla se colocó en una cubeta de electroporación fría de 0,2 cm de distancia entre los electrodos y la mezcla se sometió a un pulso de $2,2 \mathrm{kV}$. Las variables capacitancia y resistencia se fijaron en $25 \mu \mathrm{F}$ y 200 ohm $(\Omega)$, respectivamente. Inmediatamente luego del pulso eléctrico, se añadió $1 \mathrm{ml}$ de medio LB sin antibiótico a las bacterias y se las incubó $1 \mathrm{~h}$ a $37^{\circ} \mathrm{C}$ con agitación. Se sembraron 200 y 300 $\mu \mathrm{l}$ de cultivo en placas de LB con el agregado de antibiótico de selección (Ampicilina $100 \mu \mathrm{g} / \mathrm{ml}$ ). Las placas se incubaron $18-24 \mathrm{~h}$ a $37^{\circ} \mathrm{C}$.

\section{A.2.2.3. Colony PCR}

Con palillos estériles se tomaron las colonias resultantes de las diferentes transformaciones y fueron estriadas en una placa con antibiótico. El remanente de bacterias fue depositado en un tubo eppendorf con agua estéril, reuniendo hasta 10 colonias en cada tubo. Los tubos eppendorf fueron hervidos durante quince minutos, para provocar la lisis celular y liberación del DNA plasmídico. Posteriormente, cada tubo se centrifugó a 14-18.000 X g durante $5 \mathrm{~min}$. Las reacciones de amplificación se realizaron en las condiciones descriptas anteriormente, utilizando $1 \mu \mathrm{l}$ del sobrenadante como molde en $10 \mu \mathrm{l}$ de volumen final y empleando los primers correspondientes. Los pooles que presentaron una señal positiva por PCR fueron analizados en una colony PCR individual, con una colonia por tubo, a partir de las estrías del proceso anterior. 


\section{A.2.2.4. Reacciones de amplificación por PCR}

Las reacciones de amplificación de DNA fueron llevadas a cabo en los cicladores térmicos Eppendorf (Mastercycler Gradient) y Thermo (PCR Sprint). Las reacciones en las que se iba a utilizar el producto de amplificación para clonación se utilizó la polimerasa Taq (Embiotec) si el producto era menor a 1000 pb. En las reacciones de caracterización se usó la misma polimerasa. La mezcla de reacción fue diseñada de acuerdo a las indicaciones de los fabricantes la enzima. La mezcla de reacción fue diseñada de acuerdo a las indicaciones de los fabricantes la enzima, variando únicamente la concentración de $\mathrm{MgCl}_{2}$. Para la clonación de productos de más de 1000 pb se utilizó la enzima Long Taq (Dongsheng Biotech Co., Ltd.), siguiendo las recomendaciones del fabricante y variando la concentración de $\mathrm{MgCl}_{2}$ y enhancer provisto por el fabricante.

\section{A.2.3. Métodos que involucran cultivo celular.}

\section{A.2.3.1. Mantenimiento de células}

Las células High Five ${ }^{\mathrm{TM}}$ (BTI-TN-5B1-4) y UFL-Ag se mantuvieron a $27^{\circ} \mathrm{C}$ en medio Grace's (Invitrogen ${ }^{\mathrm{TM}}$ ) o TC-100 (Gibco ${ }^{\circledR}$ ) suplementado con $10 \%$ de suero fetal bovino (Bioser) y $50 \mu \mathrm{g} / \mathrm{ml}$ de gentamicina (Parafarm).

\section{A.2.3.2. Congelamiento}

Para el congelamiento se parte de monocapas de células confluentes de frascos $\mathrm{t} 25$. Se extrae el medio de cultivo y se agregan $5 \mathrm{ml}$ de medio Grace's o TC-100 con $10 \%$ SFB y $10 \%$ DMSO. Se suspenden las células mecánicamente y se alicuotan en crioviales. Luego se procede a un congelamiento graduado hasta $-80^{\circ} \mathrm{C}$, colocando los crioviales en contacto con una suspensión de etanol o glicerol.

\section{A.2.3.3. Transfecciones}

Como reactivo de transfección se utiliza Cellfectin o Cellfectin II (Invitrogen ${ }^{\mathrm{TM}}$ ). Se utiliza el protocolo sugerido por el fabricante. Brevemente, para la transfección de una placa de $10 \mathrm{~cm}^{2}$ se realiza una mezcla de DNA a transfectar con $200 \mu \mathrm{l}$ de medio sin suero y otra mezcla de $5 \mu \mathrm{l}$ de Cellfectin y $200 \mu \mathrm{l}$ de medio sin suero. Las mezclas de DNA y Cellfectin se mezclan por goteo suave y se espera 15 minutos (Cellfectin II) o 30 minutos (Cellfectin) para permitir la formación de complejos DNA-Reactivo de transfección. Se retira el sobrenadante de la placa de cultivo a transfectar y se lava 3 veces con medio sin suero. Finalmente, se gotea suavemente la mezcla de transfección sobre la placa. Luego se agregan $400 \mu \mathrm{l}$ adicionales de medio sin suero para completar el volumen mínimo de medio requerido por la placa para la supervivencia de las células. Al día siguiente se extrae el medio de transfección y se agregan $2 \mathrm{ml}$ de medio completo.

\section{A.2.3.4. Generación de líneas celulares transgénicas.}

Para el aislamiento de poblaciones celulares clonales se utilizó el método de dilución terminal (InsectSelect ${ }^{\text {TM }}$ BSD System, 2008). En este método se siembran diluciones seriadas de las células previamente transfectadas en placas multiwell. Se utiliza una placa de 96 wells y las células se diluyen de tal manera que en la primera fila de la placa (12 wells) se siembran 1000 células por well. En la segunda fila se siembran 500 células por well y se continúa diluyendo 2 veces la concentración cada fila. Luego las diluciones sembradas en cada well son seleccionadas mediante el agregado de antibiótico (Blasticidina 40 $\mu \mathrm{g} / \mathrm{ml})$. En algunos wells de alguna dilución sobrevivirá una única célula que formará una microcolonia luego de varios días. Se considera que cada well en el cual se formó una única microcolonia proviene de una única célula y por lo tanto representa una población clonal. Cada población clonal es repicada e infectada para observar la expresión del transgén. Para asegurar la homogeneidad genética de los clones, la dilución terminal se vuelve a repetir dos o tres veces más, rescatando en cada repetición células de una única microcolonia.

\section{A.2.3.5. Métodos que involucran manipulación de baculovirus en cultivo celular}

Para el mantenimiento de virus en cultivo celular, se siguieron los protocolos sugeridos en los libros de referencia "Baculovirus Expression Vectors: A Laboratory Manual" (O'Reilly, Miller, \& Luckow, 1994) y "Baculovirus and Insect Cell Expression Protocols" (Murhammer, 2008). 


\section{A.3. Lista de primers utilizados y reacciones de PCR}

\begin{tabular}{|c|c|}
\hline Primer & Secuencia \\
\hline Upr10-Ndel & GCCCATATGCACAGTCAACGCCGGCC \\
\hline Lpr10-Sgf10 & GCCCGCGATCGCGACGATATTGAAATGGTTGAAATAAATATAC \\
\hline Lpr10-Sgfl & GCCCGCGATCGCGACGATATTGAAATGGTTGAAATAAATATAC \\
\hline Uprom-Ndel & GCCCCATATGAAGTTGCAGCTCAAGCAGGATTGT \\
\hline Ppolhrev-Notl & CATTGCGGCCGCAATTCAAGCTTAGTTATAGCAAATTTTACTAC \\
\hline Uup-Rsrll & CCCCGGTCCGATGACCGAATTGAGCAACGCG \\
\hline Lup-Sfil & CTAGTTGGCCGCCTCGGCCTGCTGACTAAGCGTAGACC \\
\hline Lred-Sfil & CGCTTAGTGGCCGAGGCGGCCAACTAGAATGCAGTGAAAAAAATG \\
\hline $\mathrm{SV} 40 / \mathrm{CcdB}-\underline{\underline{X m a l}}$ & ATGGACCACCCCGGGTTCCTGTAGCGGCCGCG \\
\hline Polhi-Sgfl & AAATTTGCGATCGCTATGCCAGATTATACG \\
\hline Ldw- $\underline{B g I I I}$ & GGAAAGATCTATACACACGTTAGGCGAGCGCCG \\
\hline eGFP/Up-EcoRI & TCCATCGAATTCATGGTGAGCAAGGGC \\
\hline eGFP/Dw- $\underline{\text { Xhol }}$ & CTGATAAGCTTCTCGAGTCGCGGCCG \\
\hline Polhi-Sgfl & AAATTTGCGATCGCTATGCCAGATTATACG \\
\hline AgDwrec & AACCCGTAAAGCCGCCGTTG \\
\hline AgUpsrec & GGCGCGAGTTAAATAGTCTG \\
\hline $\mathrm{SV} 40 / \mathrm{CcdB}-\underline{\underline{X m a l}}$ & ATGGACCACCCCGGGTTCCTGTAGCGGCCGCG \\
\hline LacZ & TGGATCTGCAACATGTCCCAGGTGA \\
\hline ppolhAg600UpHindIII & TGTACAAAGCTTCTAATTGCGTAAAAATG \\
\hline pie1Agfw & TATAAGATCTCAGGGTACAATTG \\
\hline pie1Agrev & CATGAAGATCTATTTATACC \\
\hline PegtAg600-Up & TCGTCCAAGCTTTGCGCACCTATCAGCT \\
\hline PegtAg600-Down & ATAAAAAGCTTCGTAAATGCAGTTCAAT \\
\hline chiA-Up-Kpnl & TGGTACCGTATGAAACTAGCAATTGTGTC \\
\hline chiA-Down-Xhol & GGCTCGAGGCTATCCTTTACAGAACGCGTCAAGTCC \\
\hline gp37Ep-Up-EcoRI & GGAATTCCAGATATGATAGTACTGATAATATTG \\
\hline gp37Ep-Down-Pstl & AACTGCAGTTAAAACTCGTCATTTTGT \\
\hline promgp37fw & GATTCGGCAGGGCGATTTAC \\
\hline polyAChiArev & CGCACAATCGTTCCATGAACC \\
\hline polh-back & CTCCCTCTGGAGCTGTA \\
\hline hr1AgMNPVforw & GGTGGCCCCGGGGGGAGCGCATGCCTAATTAATGAG \\
\hline hr1AgMNPVrev & ATCGGAATTCGATTTGTACATGGCCCAAGTG \\
\hline PpolhAg600-Up & TGTACAAAGCTTCTAATTGCGTAAAAATG \\
\hline PpolhAg600-Down & TAATCAAGCTTAGTTATAGCAAATTTTA \\
\hline PieEpap-Up & CATCAAGCTTCCCGCATCAC \\
\hline PieEpap-Down & СACACTCCATAAGCTTTGTCTG \\
\hline PegtEp-Up & TCGTCCAAGCTTTGCGCACCTATCAGCT \\
\hline PegtEp-Down & GTCCACAAGCTTACTGATGTTGGAG \\
\hline PgraEp-Up & AAATAATGAAGCTTAAGCATGTGGA \\
\hline PgraEp-Down & ACCTCAAAGCTTTGTTATATCCTATAAT \\
\hline 1629revNotIXhol & GTACGCGGCCGCTCGAGCGACGCACCTCTGTTTACCG \\
\hline
\end{tabular}




\begin{tabular}{|c|l|}
\hline Primer & Secuencia \\
\hline 16290RFfwNotlBamHI & GCTAGCGGCCGCGGATCCATTATGGATCGCCAATATCAATC \\
\hline Nter1629Fw & CTCGCCACTACAATGCTG \\
\hline Nter1629Rv & TGTTAGGCACGGGAGAAG \\
\hline Mid1629Fw & AATAGTTGAGGTGCCGACTG \\
\hline Mid1629Rv & ACCCTCGTCGTTAGAAGTTG \\
\hline Cter1629Fw & GTACACTAACGACAGTGATG \\
\hline Cter1629Rv & TAAGCGCTAGATTCTGTGC \\
\hline UpromNcol & CTAGGGTACCATGGAAGTTGCAGCTCAAGCAGGATTGT \\
\hline Dw1629defNcol & GTACGGTACCATGGTTCAACGTTTTCGGCCGTTC \\
\hline 1629delfw & CGTTGTATTGCCCGAAAACG \\
\hline 1629delrev & GACCGCTTGTATGAAAGCAC \\
\hline
\end{tabular}




\section{A.3.1. Lista de reacciones de PCR}

\begin{tabular}{|c|c|c|c|c|c|c|c|c|c|c|}
\hline Molde & \begin{tabular}{|l|} 
Fragmento amplificado \\
\end{tabular} & Primers & \begin{tabular}{|l|} 
Tamaño del \\
inserto $(\mathrm{pb})$
\end{tabular} & $\mathrm{Tm}$ & \begin{tabular}{|l|} 
Tiempo de \\
extensión
\end{tabular} & polimerasa & $\begin{array}{l}{\left[\mathrm{MgCl}_{2}\right]} \\
(\mathrm{mM})\end{array}$ & Propósito del amplicón & $\begin{array}{l}\text { Nro. De } \\
\text { Ciclos }\end{array}$ & Capitulo \\
\hline Genoma AgMNPV & Promotor de $p 10$ & $\begin{array}{l}\text { Upr10-Ndel } \\
\text { Lpr10-Sgf10 }\end{array}$ & 219 & $52^{\circ} \mathrm{C}$ & 20 seg. & Taq & 1,5 & Construcción de pl3 & 35 & 2 \\
\hline Genoma AgMNPV & ORF polh +dw polh & $\begin{array}{l}\text { Polhi-Sgfl } \\
\text { Ldw-BgIII }\end{array}$ & 1272 & $45^{\circ} \mathrm{C}$ & $\begin{array}{c}\mathrm{min} .30 \\
\mathrm{seg} .\end{array}$ & Taq & 1,5 & Construcción de pl3 & 35 & 2 \\
\hline Genoma AgMNPV & $\begin{array}{c}\text { Promotor de poliedrina } \\
\text { AgMNPV }\end{array}$ & $\begin{array}{l}\text { Uprom-Ndel } \\
\text { pPolhrev-Notl }\end{array}$ & 175 & $48^{\circ} \mathrm{C}$ & 20 seg. & Taq & 1,5 & Construcción de pl3 & 35 & 2 \\
\hline Genoma AgMNPV & $\begin{array}{l}\text { upstream polh } \\
\text { AgMNPV }\end{array}$ & $\begin{array}{l}\text { Uup-Rsr } \\
\text { Lup-Sfi }\end{array}$ & 644 & $55^{\circ} \mathrm{C}$ & 40 seg. & Taq & 1,5 & Construcción de pl3 & 35 & 2 \\
\hline pDsRed1-N1 & SV40 PolyA & $\begin{array}{c}\text { Lred-Sfi } \\
\text { SV40/CcdB-Xmal }\end{array}$ & 256 & $50^{\circ} \mathrm{C}$ & 20 seg. & Taq & 1,5 & Construcción de pl3 & 35 & 2 \\
\hline $\begin{array}{l}\text { Producto de PCR (up. } \\
\text { polh) y (SV40 PolyA) }\end{array}$ & \begin{tabular}{|c|} 
Upstream polh \\
AgMNPV + polyA SV40
\end{tabular} & Sin primers (SOE PCR) & 880 & $65^{\circ} \mathrm{C}$ & 45 seg. & Long Taq & 1,5 & Construcción de pl3 & $\begin{array}{l}15 \text { ciclos } \\
\text { (sin } \\
\text { primers) }\end{array}$ & 2 \\
\hline peGFP-N3 & ORF $g f p$ & $\begin{array}{l}\text { eGFP/Up-EcoRI } \\
\text { eGFP/Down-Xhol }\end{array}$ & 760 & $50^{\circ} \mathrm{C}$ & $1 \mathrm{~min}$. & Taq & 1,5 & Clonación de gfp en pl3 & 35 & 2 \\
\hline tox34 & ORF tox34 & $\begin{array}{l}\text { toxF } \\
\text { toxR }\end{array}$ & 900 & $45^{\circ} \mathrm{C}$ & $1 \mathrm{~min}$ & Taq & 4 & $\begin{array}{l}\text { Detección de tox34 en plásmidos y } \\
\text { virus recombinantes }\end{array}$ & 35 & 2 \\
\hline Genoma AgMNPV & $\begin{array}{l}\text { Promotor de egt de } \\
\text { AgMNPV }\end{array}$ & $\begin{array}{l}\text { PegtAg600-Up } \\
\text { PegtAg600-Down }\end{array}$ & 627 & $52^{\circ} \mathrm{C}$ & $45 \mathrm{seg}$. & Taq & 1,5 & $\begin{array}{c}\text { Clonación del promotor de egt de } \\
\text { AgMNPV en pi3-tox. }\end{array}$ & & \\
\hline Genoma EpapGV & ORF ChiA de EpapGV & $\begin{array}{l}\text { chiA-Up-Kpnl } \\
\text { chiA-Down-Xhol }\end{array}$ & 1731 & $50^{\circ} \mathrm{C}$ & $2 \mathrm{~min}$. & Long Taq & 1,5 & Clonación de ChiA en pl3 & 42 & 2 \\
\hline Genoma EpapGV & ORF gp37 de EpapGV & $\begin{array}{l}\text { gp37Ep-Up-EcoRI } \\
\text { gp37Ep-Down-Pstl }\end{array}$ & 689 & $52^{\circ} \mathrm{C}$ & $45 \mathrm{seg}$ & Taq & 1,5 & Clonación de gp37 en pl3 & 35 & 2 \\
\hline Genoma EpapGV & $\begin{array}{c}\text { Fragmento de } 5 \mathrm{~kb} \text { con } \\
\text { los genes gp37, v-Cath } \\
\text { y chiA de EpapGV }\end{array}$ & $\begin{array}{l}\text { promgp37fw } \\
\text { polyAChiArev }\end{array}$ & 5490 & $52^{\circ} \mathrm{C}$ & 10 minutos & $\begin{array}{c}\text { Long Taq } \\
\text { (Enhancer } 1 \mathrm{X})\end{array}$ & 1,5 & $\begin{array}{c}\text { Clonación del fragmento de } 5 \mathrm{~kb} \text { con } \\
\text { los genes gp37,v-Cath y chiA de } \\
\text { EpapGV en pl3 }\end{array}$ & 42 & 2 \\
\hline $\begin{array}{c}\text { Genoma AgMNPV } \\
\text { recombinante }\end{array}$ & Recombinación dw & $\begin{array}{l}\text { polhi-Sgfl } \\
\text { AgDwrec }\end{array}$ & 1382 & $52^{\circ} \mathrm{C}$ & $\begin{array}{l}1 \text { min. } 30 \\
\text { seg. }\end{array}$ & Taq & 1,5 & \begin{tabular}{|c|} 
Detección de la recombinación \\
homóloga entre AgMNPV-I-Ppol y pl3
\end{tabular} & 35 & 2 \\
\hline $\begin{array}{l}\text { Genoma AgMNPV } \\
\text { recombinante }\end{array}$ & Recombinación up & $\begin{array}{c}\text { AgUpsrec } \\
\text { SV40/CcdB-Xmal }\end{array}$ & 1346 & $52^{\circ} \mathrm{C}$ & $\begin{array}{c}1 \mathrm{~min} .30 \\
\text { seg. }\end{array}$ & Taq & 1,5 & \begin{tabular}{|c|} 
Detección de la recombinación \\
homóloga entre AgMNPV-I-Ppol y pl3
\end{tabular} & 35 & 2 \\
\hline $\begin{array}{c}\text { Genoma AgMNPV } \\
\text { parental (lacZ, I-Ppol) }\end{array}$ & Fragmento de lacZ & $\begin{array}{c}\text { LacZ } \\
\text { ppolhAg600UpHindIII }\end{array}$ & 735 & $52^{\circ} \mathrm{C}$ & $1 \mathrm{~min}$. & Taq & 1,5 & $\begin{array}{c}\text { Detección de la contaminación con } \\
\text { genoma parental en la recombinación } \\
\text { entre AgMNPV-I-Ppol y pl3 }\end{array}$ & 35 & 2 \\
\hline Genoma AgMNPV & $\begin{array}{l}\text { Promotor de } i e-1 \text { de } \\
\text { AgMNPV }\end{array}$ & $\begin{array}{l}\text { pie1Agfw } \\
\text { pie1Agrev }\end{array}$ & 438 & $48^{\circ} \mathrm{C}$ & 30 seg. & Taq & 1,5 & $\begin{array}{l}\text { Control de molde de genoma de } \\
\text { AgMNPV }\end{array}$ & 35 & 2 \\
\hline pXXL-PolhAgMNPV & $\begin{array}{l}\text { Promotor polh } \\
\text { AcMNPV + polh } \\
\text { AgMNPV }\end{array}$ & $\begin{array}{c}\text { Bac1 } \\
\text { polh-back }\end{array}$ & 1120 & $52^{\circ} \mathrm{C}$ & $\begin{array}{c}1 \mathrm{~min} .20 \\
\text { seg. }\end{array}$ & Taq & 1,5 & $\begin{array}{l}\text { Chequeo de la clonación de ORF de } \\
\text { poliedrina de AgMNPV en } \mathrm{pXXL}\end{array}$ & 35 & 3 \\
\hline Genoma AgMNPV & $\begin{array}{l}\text { Fragmento } h r 1 \text { de } \\
\text { AgMNPV }\end{array}$ & $\begin{array}{l}\text { hr1AgMNPVforw } \\
\text { hr1AgMNPVrev }\end{array}$ & 1768 & $60^{\circ} \mathrm{C}$ & $2 \mathrm{~min}$. & $\begin{array}{c}\text { Long Taq } \\
\text { (Enhancer 2X) }\end{array}$ & 1,5 & $\begin{array}{c}\text { Clonación del fragmento } h r 1 \text { de } \\
\text { AgMNPV }\end{array}$ & 42 & 3 \\
\hline Genoma AgMNPV & $\begin{array}{l}\text { Promotor de ie-1 de } \\
\text { AgMNPV }\end{array}$ & $\begin{array}{l}\text { pie1Ag-fw } \\
\text { pie1Agrev }\end{array}$ & 438 & $48^{\circ} \mathrm{C}$ & $30 \mathrm{seg}$. & Taq & 1,5 & $\begin{array}{c}\text { Clonación del promotor de ie-1 } \\
\text { de AgMNPV }\end{array}$ & 35 & 5 \\
\hline Genoma AgMNPV & $\begin{array}{l}\text { Promotor de egt de } \\
\text { AgMNPV }\end{array}$ & $\begin{array}{l}\text { PegtAg600-Up } \\
\text { PegtAg-Down }\end{array}$ & 627 & $55^{\circ} \mathrm{C}$ & $45 \mathrm{seg}$. & Taq & 1,5 & $\begin{array}{c}\text { Clonación del promotor de egt de } \\
\text { AgMNPV }\end{array}$ & 35 & 5 \\
\hline Genoma AgMNPV & $\begin{array}{l}\text { Promotor de polh } \\
\text { AgMNPV }\end{array}$ & $\begin{array}{l}\text { PpolhAg600-Up } \\
\text { pPolhrevSOE }\end{array}$ & 627 & $52^{\circ} \mathrm{C}$ & $45 \mathrm{seg}$. & Taq & 1,5 & $\begin{array}{c}\text { Clonación del promotor de polh de } \\
\text { AgMNPV }\end{array}$ & 35 & 5 \\
\hline Genoma EpapGV & $\begin{array}{l}\text { Promotor de ie-1 de } \\
\text { EpapGV }\end{array}$ & $\begin{array}{l}\text { Pie1Epap-Up } \\
\text { Pie1Epap-Down }\end{array}$ & 602 & $50^{\circ} \mathrm{C}$ & $45 \mathrm{seg}$. & Taq & 1,5 & $\begin{array}{c}\text { Clonación del promotor de ie-1 } \\
\text { de EpapGV }\end{array}$ & 35 & 5 \\
\hline Genoma EpapGV & $\begin{array}{c}\text { Promotor de egt de } \\
\text { EpapGV }\end{array}$ & $\begin{array}{l}\text { PegtEP-Up } \\
\text { PegtEP-Down }\end{array}$ & 645 & $52^{\circ} \mathrm{C}$ & $45 \mathrm{seg}$. & Taq & 1,5 & $\begin{array}{c}\text { Clonación del promotor de egt de } \\
\text { EpapGV }\end{array}$ & 35 & 5 \\
\hline Genoma EpapGV & $\begin{array}{c}\text { Promotor de gra } \\
\text { EpapGV }\end{array}$ & $\begin{array}{l}\text { PgraEp-Up } \\
\text { PgraEp-Down }\end{array}$ & 620 & $50^{\circ} \mathrm{C}$ & $45 \mathrm{seg}$. & Taq & 1,5 & $\begin{array}{c}\text { Clonación del promotor de gra de } \\
\text { EpapGV }\end{array}$ & 35 & 5 \\
\hline Genoma AgMNPV & $\begin{array}{l}\text { ORF de } 1629 \text { de } \\
\text { AgMNPV }\end{array}$ & $\begin{array}{c}\text { 1629revNot|Xhol } \\
\text { 16290RFfwNotlBamHI }\end{array}$ & 2000 & $50^{\circ} \mathrm{C}$ & $\begin{array}{c}2 \mathrm{~min} .30 \\
\text { seg. }\end{array}$ & $\begin{array}{c}\text { Long Taq } \\
\text { (Enhancer } 1 \mathrm{X})\end{array}$ & 1,5 & $\begin{array}{c}\text { Clonación del ORF de } 1629 \text { de } \\
\text { AgMNPV }\end{array}$ & 35 & 6 \\
\hline $\begin{array}{c}\text { Bácmido bApGOZA } \\
\text { Genoma AcMNPV wt }\end{array}$ & $\begin{array}{c}\text { Fragmento N-terminal } \\
\text { del ORF de } 1629 \text { de } \\
\text { AcMNPV }\end{array}$ & $\begin{array}{l}\text { Nter1629Fw } \\
\text { Nter1629Rv }\end{array}$ & 345 & $52^{\circ} \mathrm{C}$ & 30 seg. & Taq & 1,5 & $\begin{array}{c}\text { Verificación de la deleción de } 1629 \text { del } \\
\text { bácmido }\end{array}$ & 35 & 6 \\
\hline $\begin{array}{c}\text { Bácmido bApGOZA } \\
\text { Genoma AcMNPV wt }\end{array}$ & $\begin{array}{c}\text { Fragmento medio del } \\
\text { ORF de } 1629 \text { de } \\
\text { AcMNPV }\end{array}$ & $\begin{array}{l}\text { Mid1629Fw } \\
\text { Mid1629Rv }\end{array}$ & 391 & $52^{\circ} \mathrm{C}$ & 30 seg. & Taq & 1,5 & $\begin{array}{c}\text { Verificación de la deleción de } 1629 \text { del } \\
\text { bácmido }\end{array}$ & 35 & 6 \\
\hline $\begin{array}{c}\text { Bácmido bApGOZA } \\
\text { Genoma AcMNPV wt }\end{array}$ & $\begin{array}{c}\text { Fragmento C-terminal } \\
\text { del ORF de } 1629 \text { de } \\
\text { AcMNPV }\end{array}$ & $\begin{array}{l}\text { Cter1629Fw } \\
\text { Cter1629Rv }\end{array}$ & 381 & $52^{\circ} \mathrm{C}$ & $30 \mathrm{seg}$. & Taq & 1,5 & $\begin{array}{c}\text { Verificación de la deleción de } 1629 \text { del } \\
\text { bácmido }\end{array}$ & 35 & 6 \\
\hline pl3-GFP & $\begin{array}{c}\text { Plásmido completo } \\
\text { excluyendo parte del } \\
\text { ORF de } 1629 \text { y ORF de } \\
\text { poliedrina } \\
\end{array}$ & $\begin{array}{c}\text { UpromNcol } \\
\text { Dw1629defNcol }\end{array}$ & 4441 & $55^{\circ} \mathrm{C}$ & $5 \mathrm{~min}$. & $\begin{array}{c}\text { Long Taq } \\
\text { (Enhancer } 2 \mathrm{X} \text { ) }\end{array}$ & 3 & $\begin{array}{l}\text { Generación del plásmido } \\
\text { pl3 } \Delta 1629 \mathrm{GFP}\end{array}$ & 42 & 6 \\
\hline plB-1629AgMNPB & \begin{tabular}{|c|} 
Fragmento intermedio \\
de 1629 de AgMNPV
\end{tabular} & $\begin{array}{l}\text { 1629delfw } \\
\text { 1629delrev }\end{array}$ & 142 & $50^{\circ} \mathrm{C}$ & 20 seg. & Taq & 1,5 & $\begin{array}{c}\text { Detección de clones de plB- } \\
\text { 1629AgMNPV }\end{array}$ & 35 & 6 \\
\hline
\end{tabular}




\section{Referencias}

Green, M. R. y Sambrook, J. (2012). Molecular Cloning: A Laboratory Manual (Fourth Edition): Cold Spring Harbor Laboratory Press.

InsectSelect ${ }^{\mathrm{TM}}$ BSD System, I. (2008). For Stable Expression of Heterologous Proteins in Lepidopteran Insect Cell Lines using pIB/V5-His Catalog nos. K820-01, K825-01, V8020-01.

Murhammer, D. W. (2008). Baculovirus and Insect Cell Expression Protocols. Methods in Molecular Biology, 388. doi: 10.1007/978-1-59745-457-5

O'Reilly, D.R.; Miller, L.K.; Luckow, V.A. (1994). Baculovirus Expression Vectors: A Laboratory Manual. Oxford University Press. 347 pages. 

Notas: 
Notas: 
Notas: 
Notas: 
Notas: 
Notas: 